INSTITUTO DE PESQUISAS ENERGÉTICAS E NUCLEARES

Autarquia associada à Universidade de São Paulo

\title{
AVALIAÇÃO DO CONTEÚDO DE MERCÚRIO, METILMERCÚRIO E OUTROS ELEMENTOS DE INTERESSE EM PEIXES E EM AMOSTRAS DE CABELOS E DIETAS DE PRÉ-ESCOLARES DA REGIÃO AMAZÔNICA
}

\section{LUCIANA APARECIDA FARIAS}

Tese apresentada como parte dos requisitos para obtenção do Grau de Doutor em Ciências na Área de Tecnologia Nuclear - Aplicações.

Orientadora:

Dra. Déborah Inês Teixeira Fávaro

São Paulo

2006 
Ao meu filho Otávio, com todo amor e carinho. 


\section{Agradecimentos}

À Dra. Déborah Inês Teixeira Fávaro, minha orientadora, que nestes últimos anos muito contribuiu para o meu crescimento profissional e pessoal, dando-me a segurança necessária para superar os obstáculos que todo trabalho de pesquisa apresenta.

À Dra. Lucia Yuyama e colegas do Laboratório de SNutrição e Físico-Química de Alimentos da Coordenação de Pesquisas em Ciências da Saúde, INNPA, que muito me auxiliaram na parte experimental do meu trabalho e cuja cooperação foi decisiva para a concretização deste estudo.

Aos amigos Andreza e Osman, pois no caminho que cada um deve percorrer são somente os grandes amigos que suavizam e nos ajudam a superar as crises. Andreza, obrigada pela paciência e desculpe pelos momentos de divergência. Osman, obrigada por me auxiliar com seus conhecimentos.

Ao amigo Paulo Sérgio que sempre me apoiou e foi meu companheiro constante durante todo mestrado. E não me abandonou no doutorado.

A todos os amigos do Laboratório de Análise por Ativação Neutrônica (LANN-CRPQ) do IPEN, em particular a Dra. Vera Maihara, por todo apoio técnico, companheirismo e paciência.

Ao professor e amigo Marco Aurélio Perez, que acreditou no meu potencial. Obrigada pela sua ajuda, pois ela me incentivou a seguir em frente. Antes e agora.

Aos meus familiares, especialmente à minha avó, à minha sogra e à minha mãe e ao meu pai. 
E à Coordenação de Aperfeiçoamento de Pessoal de Sivivel Superior (CAPES), pela concessão de uma bolsa de doutorado, sem a qual a realização deste trabalho não teria sido possivel. 


\section{O DRAMA DO MERCÚRIO EM MINAMATA}

“Tomoko Uemura, de 17 anos, repousa no colo da mãe. Ela é cega, surda e muda. Tem os braços e as pernas deformados. Nasceu em 1955, anos depois que uma companhia química, a Chisso, derramou mercúrio na Baía de Minamata, no Japão. Uma geração inteira cresceu marcada pelo desastre ecológico. Em abril de 1997, depois de quatro décadas de investigação, 10.353 pessoas foram declaradas aptas a receber indenização da Chisso. Foram anos de luta, que começara em 1972, quando o fotógrafo americano W. Eugene Smith fez a foto da menina. A imagem transformou-se no resumo brutal da tragédia. Hoje, as águas de Minamata estão limpas. Tomoko morreu em 1977."

\section{ÉPOCA ONLINE - ESPECIAIS MILÊNIO VERGONHAS - DESASTRE ECOLÓGICO \\ 30 de abril de 1997}

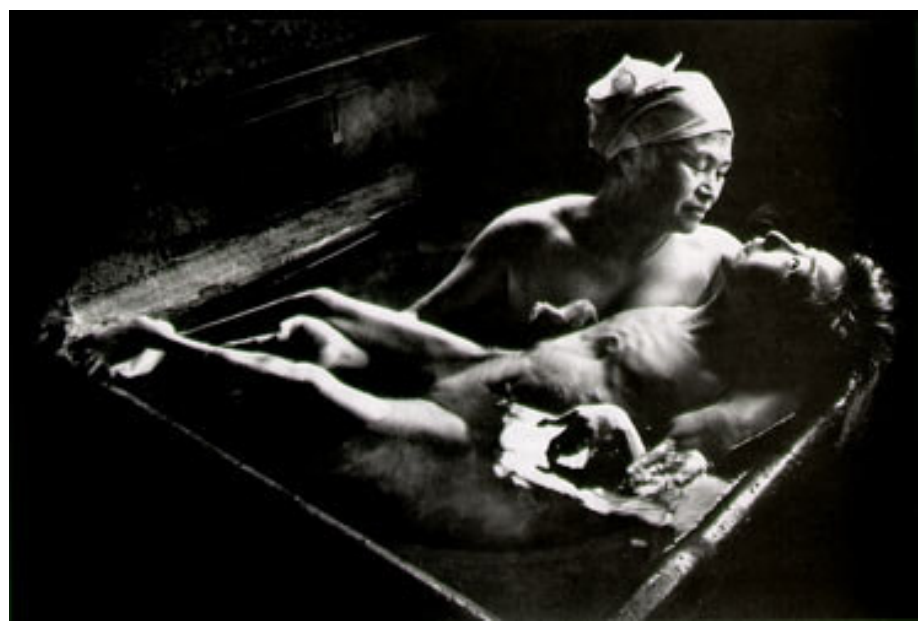

Foto de William Eugene Smith, Tomoko Uemura em seu banho, Minamata, 1972. Minolta SRT101 + Rokkor 16mm f/2.8. 


\title{
AVALIAÇÃO DO CONTEÚDO DE MERCÚRIO, METILMERCÚRIO E OUTROS ELEMENTOS DE INTERESSE EM PEIXES, CABELOS E DIETAS DE PRÉ- ESCOLARES DA REGIÃO AMAZÔNICA
}

\author{
RESUMO
}

\begin{abstract}
Vários estudos mostram que algumas regiões da Amazônia sofrem impacto por mercúrio $(\mathrm{Hg})$, decorrente de processos naturais e antrópicos. O Parque Nacional do Jaú PNJ, é o único Parque do Brasil que protege toda a bacia de um rio de água escura (Rio Jaú), terras inundáveis e reservas tropicais, condições que favorecem a metilação do $\mathrm{Hg}$ na biota aquática, portanto, expondo a população ribeirinha à contaminação e tornando a região passível de impactação natural por $\mathrm{Hg}$. Estudos preliminares de dietas de préescolares de comunidades do PNJ, têm demonstrado concentrações preocupantes de Hg. O presente estudo avaliou as concentrações de $\mathrm{Hg}$ total, de micronutrientes $(\mathrm{Ca}, \mathrm{Fe}, \mathrm{K}, \mathrm{Na}$,
\end{abstract} $\mathrm{Se}$ e $\mathrm{Zn}$ ) e de macronutrientes (proteínas, lipídeos, cinzas, energia e carbohidratos) em dietas de pré-escolares da região do PNJ e outras comunidades próximas. Avaliou-se também os níveis de Hg total e MeHg em amostras de cabelos dessas crianças e também, cabelos de crianças residentes em vários bairros da cidade de Manaus e pescados mais consumidos por essa população. A partir desses resultados, foi possível fazer uma avaliação nutricional das dietas e à exposição ao $\mathrm{Hg}$ e $\mathrm{MeHg}$ de crianças do PNJ e comunidades próximas, e da cidade de Manaus, AM. A quantificação de $\mathrm{Hg}$ total e $\mathrm{MeHg}$ foi feita por espectrometria de absorção atômica com geração de vapor frio (CV AAS). A determinação dos micronutrientes foi feita pela técnica de ativação neutrônica (AAN) e os macronutrientes, de acordo com as metodologias preconizadas pela AOAC (USA). Todos os métodos foram desenvolvidos e validados, quanto à precisão e exatidão, por meio da análise de materiais de referência com valores certificados para os elementos determinados. Além disso, foi realizada a avaliação das fontes de incerteza para a determinação de $\mathrm{Hg}$ e $\mathrm{MeHg}$ sendo calculada a incerteza padrão expandida. Os teores obtidos para $\mathrm{Hg}$ total nas amostras de dietas e $\mathrm{Hg}$ total e MeHg em cabelos do PNJ, estiveram bem acima dos valores encontrados em diferentes localidades da região Amazônica, bem como de localidades próximas ao PNJ. Para muitas crianças os valores de ingestão para $\mathrm{Hg}$, ultrapassou-se o valor de $5 \mu \mathrm{g}$ de $\mathrm{Hg} / \mathrm{kg}$ de peso corpóreo/semana (PTWI). As crianças da cidade de Manaus apresentaram teores muito menores de $\mathrm{Hg}$ nas amostras de cabelo, ao contrário do PNJ, mesmo sendo ecossistemas interligados. Concluise, portanto, que para a população que possui maior capacidade de escolha de produtos alimentícios fornecedores de proteínas, a ingestão de peixe é menor e conseqüentemente a ingestão de $\mathrm{Hg}$ também. Os resultados obtidos pela técnica de AAN forneceram valores de concentração confiáveis para elementos nutricionalmente importantes como Ca, $\mathrm{Fe}, \mathrm{K}, \mathrm{Na}$, $\mathrm{Se}$ e Zn, os quais foram comparados aos valores de DRIs (Dietary Reference Intakes). De uma maneira geral, verificou-se prevalência de inadequação com relação aos micronutrientes e déficit protéico-calórico, para as dietas analisadas no presente estudo. Isso vem confirmar o alto nível de risco e a vulnerabilidade dessa população às deficiências nutricionais e à contaminação por $\mathrm{Hg}$. Vários fatores externos podem influenciar a vulnerabilidade da população aos efeitos tóxicos do $\mathrm{MeHg}$, tais como: idade, sexo, estado nutricional e de saúde, ingestão e interação dietética. Objetivando avaliar também a influência do processo de coçcão na perda de nutrientes e de $\mathrm{Hg}$ total, em uma tentativa de contribuir para futuros estudos nutricionais, avaliou-se o teor de $\mathrm{Hg}$ e dos micronutrientes $\mathrm{Ca}, \mathrm{Fe}, \mathrm{K}, \mathrm{Na}$, Se e $\mathrm{Zn}$ em espécies de pescados mais consumidos pela população da cidade de Manaus e comunidades próximas, preparadas sob diferentes 
formas de cocção (in natura, cozido, frito e assado). Verificou-se que a variabilidade na perda dos elementos minerais e do $\mathrm{Hg}$, para cada processo de cocção, parece estar mais em função da espécie do que a forma de preparo. Verificou-se também, que as espécies predadoras apresentaram os maiores teores de $\mathrm{Hg}$ e Se, conforme era esperado. Discute-se a correlação entre $\mathrm{Hg}$ e $\mathrm{Se}$ em peixes. Conclui-se que, embora as pesquisas atuais concordem que possa existir um BG (nível básico) de $\mathrm{Hg}$ na Amazônia, a exposição contínua ao $\mathrm{Hg}$ pela via alimentar, mesmo considerando os baixos teores do metal encontrados em algumas espécies de peixes, permitem supor que no decorrer do tempo esta situação possa se agravar, principalmente em comunidades cuja dieta não é diversificada apresenta deficiências nutricionais sérias e se constitua principalmente de pescado. $\mathrm{O}$ presente estudo pretendeu também, além da avaliação do estado nutricional e da exposição ao Hg de crianças do Parque Nacional do Jaú e da cidade de Manaus, AM, contribuir de forma a subsidiar futuras ações de políticas públicas. 


\title{
ASSESSMENT OF THE CONTENT OF MERCURY, METHYLMERCURY AND OTHER ELEMENTS OF INTEREST IN FISH, HAIR AND DIETS OF PRE-SCHOLL CHILDREN OF THE AMAZON REGION
}

\begin{abstract}
Studies show that some regions of the Amazon region suffer mercury $(\mathrm{Hg})$ impacts as a direct result of both natural and anthropogenic processes. Jaú National Park (PNJ) is the only National Park in Brazil that protects an entire black water basin (Jaú River), flood land and tropical reserve. These conditions favor $\mathrm{Hg}$ methylation in the aquatic biota. This in turn, exposes riverine populations to $\mathrm{Hg}$ contamination as well as the adjacent regions. Preliminary studies of pre-school diets from PNJ communities have shown that these diets have a worrisomely high $\mathrm{Hg}$ content. The present study assessed total $\mathrm{Hg}$ content, micronutrients ( $\mathrm{Ca}, \mathrm{Fe}, \mathrm{K}, \mathrm{Na}, \mathrm{Se}$ and $\mathrm{Zn}$ ) and macronutrients (proteins, lipids, ash, energy, carbohydrate) in pre-school diets in the PNJ and surrounding communities. Furthermore, total and $\mathrm{MeHg}$ levels were also determined in hair samples of these children as well as those living in several neighborhoods of the city of Manaus. Included in this determination were the fish most consumed by these populations. From these results it was possible to evaluate the nutritional content of the diets and the exposure of the children to $\mathrm{Hg}$ and $\mathrm{MeHg}$. Cold vapor atomic absorption spectrometry was used to quantify total and $\mathrm{MeHg}$. Micronutrient determination was performed using neutron activation analysis technique (NAA) and Macronutrient through AOAC methodologies (USA). All analytical methods were developed and validated for precision and accuracy by means of reference materials analyses with certified values for the elements determined. Furthermore, the uncertainty sources for $\mathrm{Hg}$ and $\mathrm{MeHg}$ determination were assessed and the expanded uncertainties were calculated. Total $\mathrm{Hg}$ levels in diets and total and $\mathrm{MeHg}$ levels for hair samples, were well above those values found in different localities of the Amazon region. This also holds true for those surrounding areas of the JNP. For many children $\mathrm{Hg}$ intake values passed the $5 \mu \mathrm{g} \mathrm{Hg} / \mathrm{body}$ weigh/week (PTWI). Children of the city of Manaus presented much lower $\mathrm{Hg}$ levels in hair samples in contrast to those of the PNJ even though both groups shared the same ecosystem. It can thus be concluded that populations that have a wider choice of food products for protein, have a lesser intake of fish and as a consequence less $\mathrm{Hg}$ intake. Obtained NAA results furnished reliable concentration values for important nutritional elements, mainly $\mathrm{Ca}, \mathrm{Fe}, \mathrm{K}, \mathrm{Na}$, Se and $\mathrm{Zn}$. From these values the daily intake was calculated and compared to the DRIs (Dietary reference intakes). In general, the diets analysed in this study presented inadequate and deficient protein-caloric levels, confirming these populations' high risk and vulnerability to nutritional deficiencies and to $\mathrm{Hg}$ exposure. Several external factors can obviously influence the vulnerability of these populations to the toxic effects to $\mathrm{MeHg}$ such as: age, sex, health and nutritional status, intake and dietary interaction. In order to evaluate the influence of the cooking processes (in natura, cooked, fried, baked) regarding micronutrient and total $\mathrm{Hg}$ losses, in order to contribute to future nutritional studies, $\mathrm{Hg}$ levels and micronutrients in fish species most consumed by Manaus residents and surrounding communities were assessed. Micronutrients and $\mathrm{Hg}$ loss variability through the different cooking processes seem to be more related to fish species rather than cooking process. Furthermore, predatory species presented higher $\mathrm{Hg}$ and $\mathrm{Se}$ levels as was expected. The $\mathrm{Hg}$ and Se correlation in fish is also discussed. Although research shows a high $\mathrm{Hg}$ background in the Amazon the continuous exposure through food can in time worsen especially in communities that do not have diet diversification, have serious nutritional deficiencies and whose diets are mainly fish. It is hoped that this study can also
\end{abstract}


contribute to future public political actions and policies in terms of reducing dietary hazards due to $\mathrm{Hg}$ and $\mathrm{MeHg}$ exposure. 


\section{SUMÁRIO}

Capítulo 1 - Introdução ................................................................................................................................. 16

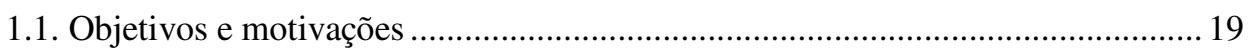

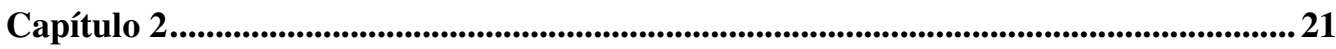

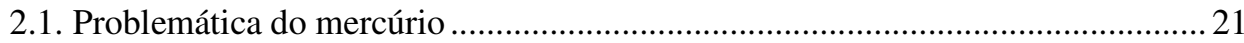

2.2. O Parque Nacional do Jaú ................................................................................. 34

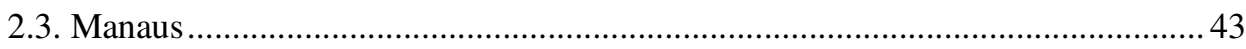

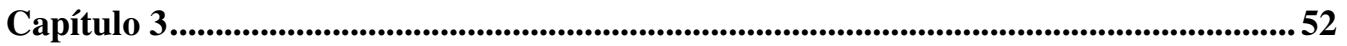

3.1. Avaliação Dietética ....................................................................................... 52

3.2. O estudo da dieta: considerações metodológicas ................................................. 56

Capítulo 4 - Metodologias analíticas ..................................................................................................... 63

4.1. Espectrometria de absorção atômica com geração de vapor frio e injeção em fluxo

(CV-AAS-FIA) - determinação de mercúrio ................................................................. 63

4.2. Análise por ativação neutrônica (AAN) - determinação de elementos essenciais e

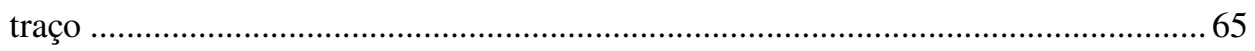

Capítulo 5 - Procedimento experimental........................................................................69

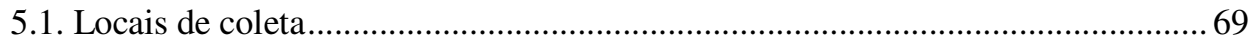

5.1.1. Parque Nacional do Jaú (PNJ) e outras comunidades da região

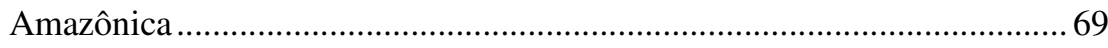

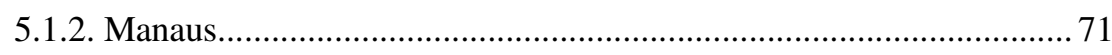

5.2. Amostragem e preparação das dietas, peixes e cabelos......................................... 73

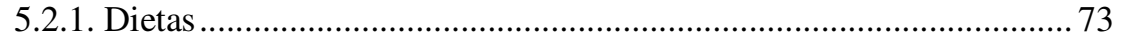

5.2.1.1. Análises físico-químicas ................................................... 76

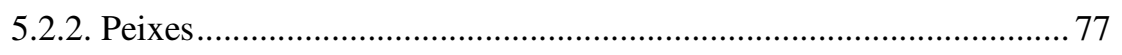

5.2.2.1 Modos de preparação dos peixes (cocção)........................... 77

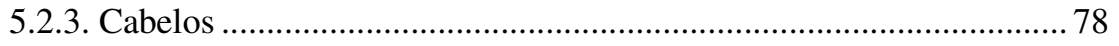

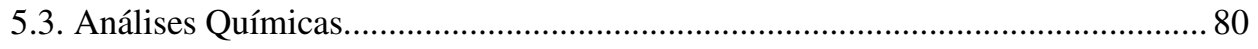


5.3.1. Análise de mercúrio total e metilmercúrio - CV AAS ....................... 80

5.3.1.1 Procedimento analítico (cabelo, dieta e peixe) .................... 80

5.3.2. Determinação de elementos traço e essenciais - Análise por Ativação Neutrônica 85

5.3.2.1. Preparo dos padrões sintéticos............................................ 85

5.3.2.2. Irradiação e contagem das amostras de dietas e peixes...... 85

5.3.2.3. Validação da metodologia ................................................... 86

5.3.2.4. Cálculo do Z score ............................................................. 86

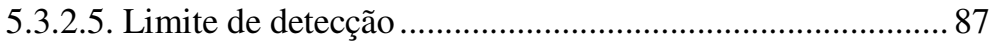

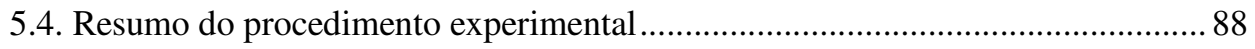

Capítulo 6 - Quantificação de mercúrio por CV AAS (dietas, peixes e cabelos) ............. 89

6.1. Validação de resultados analíticos .................................................................... 89

6.1.1. Curva de calibração ........................................................................ 90

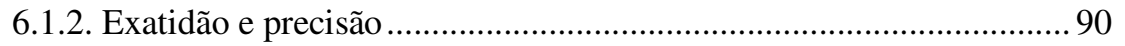

6.1.3. Participação em exercício de intercomparação................................... 91

6.1.4. Limite de detecção e limite de quantificação..................................... 92

6.2. Incertezas associadas à determinação de mercúrio................................................. 95

6.2.1. Procedimento para quantificação das incertezas associadas ............... 100

6.2.1.1. Cálculo da incerteza combinada para mercúrio total .......... 109

6.2.1.2. Cálculo da incerteza expandida para mercúrio total ........... 111

6.2.1.3. Cálculo da incerteza combinada para metilmercúrio.......... 116

6.2.1.4. Cálculo da incerteza expandida para metilmercúrio ........... 117

Capítulo 7 - Resultados e discussões ............................................................................................. 120

7.1. Resultados de Hg e MeHg pelo método de CV AAS.......................................... 120

7.1.1. Resultados das análises dos materiais de referência biológicos por

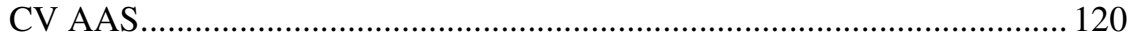

7.1.2. Resultados das análises das dietas do PNJ e comunidades próximas 124 
7.1.3. Resultados das análises de cabelo das comunidades do PNJ

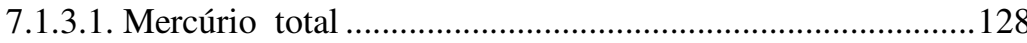

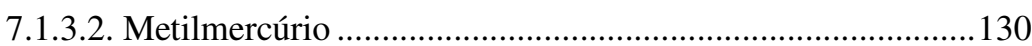

7.1.4. Resultados das análises dos peixes da cidade de Manaus - mercúrio total

132

7.1.5. Resultados das análises de cabelos ( $\mathrm{Hg}$ total e $\mathrm{MeHg}$ ) de crianças da cidade de Manaus 136

7.1.5.1. Comentários gerais a respeito da relação entre a ingestão de peixe e níveis de mercúrio em amostradas de cabelo

7.2. Resultados dos elementos determinados pelo método de análise por ativação neutrônica (AAN)

7.2.1. Resultados das análises dos materiais de referência biológicos por

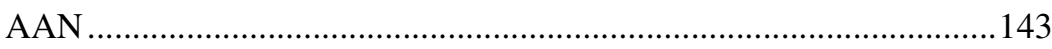

7.2.2. Resultados das análises das dietas do PNJ e demais comunidades 145

7.2.2.1. Verificação da adequação das dietas em relação aos micronutrientes $\mathrm{Ca}, \mathrm{Fe}, \mathrm{K}, \mathrm{Na}$, Se e Zn

7.3. Resultados e adequação das dietas analisadas em relação a proteínas, lipídeos e carboidratos

7.4. Resultados das análises dos peixes da cidade de Manaus 156

Capítulo 8 - Conclusões e considerações finais sobre a relação: Contaminação por mercúrio e fatores nutricionais 170

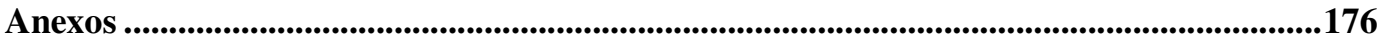

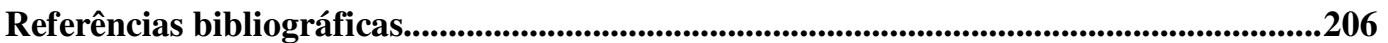




\section{LISTA DE TABELAS}

Tabela 1. Comparação do teor do $\mathrm{Hg}$ total em cabelo de crianças residentes em várias localidades do Brasil

Tabela 2. Indicadores e sintomas em função dos teores de $\mathrm{Hg}$ 29

Tabela 3. Evolução da densidade demográfica na área do PNJ, AM .37

Tabela 4. Características das crianças da cidade Manaus participantes do estudo, segundo sexo (valores médios)

Tabela 5. Valores dos limites de detecção para os elementos analisados por Análise por Ativação Neutrônica (AAN) $\left(\mathrm{mg} \mathrm{kg}^{-1}\right)$.

Tabela 6. $\mathrm{Hg}$ total e MeHg no material de intercomparação Tuna Fish Flesh Homogenate (IAEA-436)

Tabela 7. Métodos para a determinação de $\mathrm{Hg}$ e limites de detecção .94

Tabela 8. Absorbância obtida para as três determinações dos cinco padrões de $\mathrm{Hg}$ para o cálculo de $\mu\left(\mathrm{C}_{0}\right)$ para o material de referência Human Hair Spiked (IAEA 085)

Tabela 9. Absorbância obtida para as três determinações dos cinco padrões de $\mathrm{Hg}$ para o cálculo de $\mu\left(\mathrm{C}_{0}\right)$ para o material de referência Dogfish muscle (DORM-1 NRCC)

Tabela 10. Valores das variáveis $\left(\mathrm{C}_{0}, \mathrm{~m}_{\mathrm{a}}, \mathrm{V}_{\mathrm{f}}\right.$ e $\left.\mathrm{R}_{\mathrm{i}}\right)$, suas incertezas padrões e incertezas padrões relativas para o Material de Referência Dogfish muscle (DORM-1 NRCC) ${ }^{\text {a. }}$

Tabela 11. Valores das variáveis $\left(\mathrm{C}_{0}, \mathrm{~m}_{\mathrm{a}}, \mathrm{V}_{\mathrm{f}}\right.$ e $\left.\mathrm{R}_{\mathrm{i}}\right)$, suas incertezas padrões e incertezas padrões relativas para o Material de Referência Human Hair Spiked (IAEA 085) ${ }^{\mathrm{a} \ldots \ldots \ldots \ldots \ldots \ldots \ldots \ldots \ldots . . . . . .1} 110$

Tabela 12. Absorbância obtida para as três determinações dos cinco padrões de Hg para o

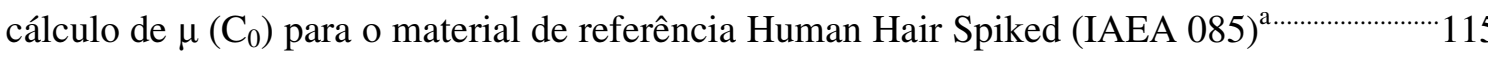

Tabela 13. Valores das variáveis $\left(\mathrm{C}_{0}, \mathrm{~m}_{\mathrm{a}}, \mathrm{V}_{\mathrm{f}}\right.$ e $\left.\mathrm{R}_{\mathrm{i}}\right)$, suas incertezas padrões e incertezas padrões relativas para o Material de Referência Human Hair Spiked (IAEA 085) ${ }^{\mathrm{a} \ldots \ldots . . . \cdots \cdots . . . . . . . . . .117}$

Tabela 14. Resultados de $\mathrm{Hg}$ total $\left(\mu \mathrm{g} \mathrm{kg}^{-1}\right)$ nos materiais de referência $(\mathrm{n}=7)$.

Tabela 15. Resultados obtidos para $\mathrm{MeHg}\left(\mathrm{mg} \mathrm{kg}^{-1}\right)$ nos materiais de referência IAEA-085 e 086 (Human Hair). 
Tabela 16. Concentração de Hg Total em dietas e Ingestão Diária de Hg de crianças em idade pré-escolar, da região Amazônica

Tabela 17. Teor de Hg total em dietas, com os desvios padrões e as incertezas expandidas para as comunidades do PNJ e demais comunidades da região Amazônica

Tabela 18. Resultados obtidos nas determinações de $\mathrm{Hg}$ total em amostras de cabelos de crianças em idade pré-escolar de diferentes ecossistemas amazônicos

Tabela 19. Teor de Hg total em cabelos, com os desvios padrões (s) e as incertezas expandidas para as comunidades do PNJ

Tabela 20. Teor de Hg total em cabelos, com os desvios padrões (s) e as incertezas expandidas para as demais comunidades da região Amazônica

Tabela 21. Resultados obtidos nas determinações de MeHg em amostras de cabelos (mg. $\left.\mathrm{kg}^{-1}\right)$ de crianças em idade pré-escolar do PNJ e diferentes ecossistemas amazônicos

Tabela 22. Teor de $\mathrm{MeHg}$ em cabelos, com os desvios padrões (s) e as incertezas expandidas para as comunidades do PNJ..... 182

Tabela 23. Teor de $\mathrm{MeHg}$ em cabelos, com os desvios padrões (s) e as incertezas expandidas para as demais comunidades da região Amazônica

Tabela 24. Resultados obtidos na análise dos peixes preparados sob diferentes formas de cocção $\left(\mu \mathrm{g} \mathrm{kg}^{-1}\right)$ e perda percentual de $\mathrm{Hg}(\mathrm{P} \%)$ 135

Tabela 25. Teor de Hg total em espécies de peixes comumente consumidas pela população da cidade de Manaus e comunidades próximas

Tabela 26. Resultados obtidos nas determinações de $\mathrm{Hg}$ total e $\mathrm{MeHg}$ em amostras de cabelos (mg. $\left.\mathrm{kg}^{-1}\right)$ de crianças em idade pré-escolar de diferentes bairros da cidade de Manaus .........136

Tabela 27. Teor de Hg total em cabelos, com os desvios padrões e as incertezas expandidas para os bairros Alvorada e Cidade Nova 186

Tabela 28. Teor de Hg total em cabelos, com os desvios padrões e as incertezas expandidas para o bairro Compensa.

Tabela 29. Teor de Hg total em cabelos, com os desvios padrões e as incertezas expandidas para o bairro Flores. 188 
Tabela 30. Teor de Hg total em cabelos, com os desvios padrões e as incertezas expandidas para o bairro Japiim

Tabela 31. Teor de Hg total em cabelos, com os desvios padrões e as incertezas expandidas para o bairro São José.

Tabela 32. Teor de $\mathrm{MeHg}$ em cabelos, com os desvios padrões e as incertezas expandidas para o bairro Alvorada

Tabela 33. Teor de MeHg em cabelos, com os desvios padrões e as incertezas expandidas para o bairro Compensa.

Tabela 34. Teor de $\mathrm{MeHg}$ em cabelos, com os desvios padrões (s) e as incertezas expandidas para o bairro Flores

Tabela 35. Teor de $\mathrm{MeHg}$ em cabelos, com os desvios padrões e as incertezas expandidas para o bairro Japiim 195

Tabela 36. Teor de $\mathrm{MeHg}$ em cabelos, com os desvios padrões (s) e as incertezas expandidas para o bairro São José 196

Tabela 37. Dados antropométricos e informações obtidas a partir do questionário respondido pela mãe ou responsável para cada criança participante do estudo

Tabela 38. Resultados obtidos $\left(\mathrm{mg} \mathrm{kg}^{-1}\right)$ na análise dos materiais de referência por AAN

Tabela 39. Resultados obtidos $\left(\mathrm{mg} \mathrm{kg}^{-1}\right)$ nas análises das dietas de pré-escolares de comunidades da região Amazônica, por AAN 145

Tabela 40. Ingestão diária de elementos essenciais de pré-escolares do Parque Nacional do Jaú (PNJ) - Ingestão média (mg/dia) e os valores de EAR e AI 146

Tabela 41. Composição centesimal e adequação das dietas das crianças das comunidades do PNJ 154

Tabela 42. Composição centesimal e adequação das dietas das crianças de comunidades da região Amazônica 154

Tabela 43. Resultados obtidos na análise dos peixes preparados sob diferentes formas de cocção para os elementos $\mathrm{Ca}, \mathrm{Fe}, \mathrm{K}, \mathrm{Na}$, Se e $\mathrm{Zn}$ e $\mathrm{Hg}\left(\mathrm{mg} \mathrm{kg}^{-1}\right)$ 204 


\section{LISTA DE FIGURAS}

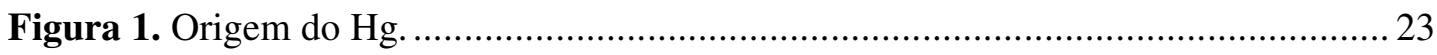

Figura 2. Paciente atendido em Minamata após contaminação com Hg. ........................ 25

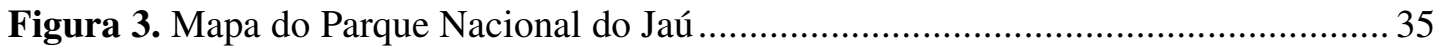

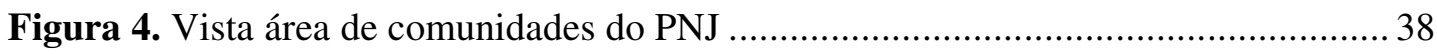

Figura 5. Utilização dos recursos naturais disponíveis no PNJ .................................. 41

Figura 6. Proporção do consumo de animais em diferentes épocas do ano pelos moradores do PNJ, entre 1995 e 2002 (dados obtidos através de monitoramento com calendário de

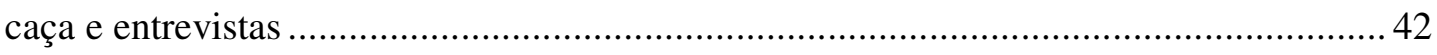

Figura 7. Cidade de Manaus, visão do Satélite MISR, (23/07/2000) ............................. 44

Figura 8. Equipamento utilizado na determinação do Hg (FIMS - Flow Injection Mercury

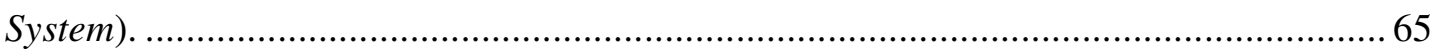

Figura 9. Representação esquemática da interação do nêutron com um núcleo alvo....... 66

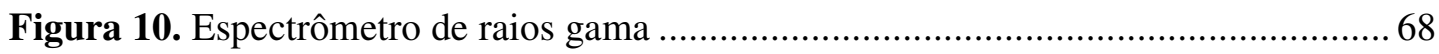

Figura 11. Mapa das Localidades amostradas no Parque Nacional do Jaú ...................... 70

Figura 12. Mapa de Manaus e bairros (bairros amostrados em destaque)...................... 72

Figura 13. Etapas do preparo das amostras de cabelo para análise. .............................. 79

Figura 14. Frascos de Teflon fechados da Savilex no bloco digestor da Tecnal.............. 81

Figura 15. Seqüência esquemática da separação do $\mathrm{MeHg}$....................................... 84

Figura 16 . Resumo do procedimento experimental ........................................... 88

Figura 17. Gráfico de apresentação dos resultados obtidos para $\mathrm{Hg}$ total na intercomparação pelos laboratórios participantes ..................................................... 177

Figura 18. Gráfico de apresentação dos resultados obtidos para mehg na intercomparação

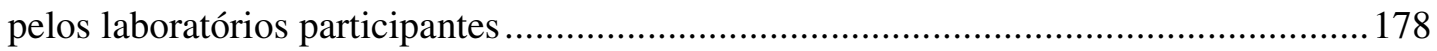

Figura 19. Fluxogramas das etapas do procedimento que contribuem na incerteza da determinação do $\mathrm{Hg}$ e $\mathrm{MeHg}$ em amostras biológicas.................................................... 97 
Figura 20. Diagrama de causa e efeito para o procedimento analítico na determinação de $\mathrm{Hg}$ total em amostras biológicas 99

Figura 21. Diagrama de causa e efeito para o procedimento analítico na determinação de $\mathrm{MeHg}$ em amostras biológicas 100

Figura 22. Gráficos de controle do procedimento proposto para análise de $\mathrm{Hg}$ total em materiais de referência.

Figura 23. Gráficos de controle do procedimento proposto para análise de $\mathrm{MeHg}$ em materiais de referência

Figura 24. Distribuição percentual de $\mathrm{Hg}$ total em dietas das comunidades do PNJ ..... 127

Figura 25. Intervalo de confiança entre as médias de $\mathrm{Hg}$ total nas dietas das comunidades estudadas 128

Figura 26. Boxplot indicando a variação do teor de $\mathrm{Hg}$ total nas amostras de cabelo em função do gênero 138

Figura 27. Boxplot indicando a variação do teor de $\mathrm{Hg}$ total nas amostras de cabelo em função do bairro.

Figura 28. Boxplot da variação do teor de $\mathrm{Hg}$ total nas amostras de cabelo em função da classe social. 140

Figura 29. Carta de controle (valores de Z-score) para os elementos analisados, nos materiais de referências analisados por AAN

Figura 30. Boxplot da variação do teor de $\mathrm{Hg}$ total nas amostras de peixe em função do processo de cocção 158

Figura 31. Boxplot da variação do teor de Ca nas amostras de peixe em função do processo de cocção.

Figura 32. Boxplot da variação do teor de Na nas amostras de peixe em função do processo de cocção. 
Figura 33. Boxplot da variação do teor de K nas amostras de peixe em função do processo de cocção

Figura 34. Box plot da variação do teor de Fe nas amostras de peixe em função do processo de cocção.

Figura 35. Boxplot da variação do teor de Se nas amostras de peixe em função do processo de cocção

Figura 36. Boxplot da variação do teor de $\mathrm{Zn}$ nas amostras de peixe em função do processo de cocção

Figura 37. Boxplot da variação do teor de Ca nas amostras de peixe em função da dieta alimentar de cada espécie.

Figura 38. Boxplot da variação do teor de Fe nas amostras de peixe em função da dieta alimentar de cada espécie. 162

Figura 39. Boxplot da variação do teor de $\mathrm{K}$ nas amostras de peixe em função da dieta alimentar de cada espécie 163

Figura 40. Boxplot da variação do teor de $\mathrm{Na}$ nas amostras de peixe em função da dieta alimentar de cada espécie

Figura 41. Boxplot da variação do teor de Se nas amostras de peixe em função da dieta alimentar de cada espécie 164

Figura 42. Boxplot da variação do teor de $\mathrm{Zn}$ nas amostras de peixe em função da dieta alimentar de cada espécie 164

Figura 43. Boxplot da variação do teor de $\mathrm{Hg}$ nas amostras de peixe em função da dieta alimentar de cada espécie. 165

Figura 44. Biplot para as amostras de peixe em função da dieta alimentar de cada espécie 
Figura 45. Representação da composição química elementar das amostras de peixe em função da dieta alimentar para cada espécie, no espaço das funções discrimantes (as

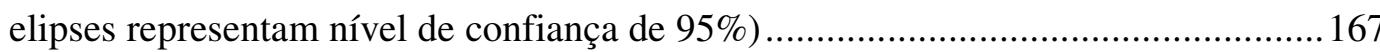




\section{LISTA DE SÍMBOLOS E ABREVIATURAS}

\section{Símbolos}

\begin{tabular}{|c|c|}
\hline As & Arsênio \\
\hline $\mathrm{B}-\mathrm{Hg}$ & Mercúrio disponível no sangue \\
\hline $\mathrm{B}-\mathrm{Se}$ & Selênio disponível no sangue \\
\hline $\mathrm{Ca}$ & Cálcio \\
\hline $\mathrm{Cd}$ & Cádmio \\
\hline $\mathrm{Cl}^{-}$ & Íon cloro \\
\hline $\mathrm{Cu}$ & Cobre \\
\hline Sn & Estanho \\
\hline $\mathrm{Fe}$ & Ferro \\
\hline $\mathrm{Hg}$ & Mercúrio \\
\hline $\mathrm{HgCl}_{4}^{-2}$ & complexo de cloreto formado com o íon mercúrio \\
\hline $\mathrm{HCl}$ & Ácido clorídrico \\
\hline $\mathrm{HNO}_{3}$ & Ácido nítrico \\
\hline $\mathrm{H}_{2} \mathrm{SO}_{4}$ & Ácido sulfúrico \\
\hline $\mathrm{K}$ & Potássio \\
\hline $\mathrm{K}_{2} \mathrm{Cr}_{2} \mathrm{O}_{7}$ & Dicromato de potássio \\
\hline $\mathrm{MeHg}$ & Metilmercúrio \\
\hline $\mathrm{Na}$ & Sódio \\
\hline $\mathrm{Pb}$ & Chumbo \\
\hline $\mathrm{Se}$ & Selênio \\
\hline $\mathrm{SnCl}_{2}$ & Cloreto estanhoso \\
\hline $\mathrm{Zn}$ & Zinco \\
\hline $\mathrm{Tl}$ & Tálio \\
\hline $\mathrm{T}_{1 / 2}$ & Tempo de meia vida \\
\hline
\end{tabular}




\section{Abreviaturas}

AAN Análise por Ativação Neutrônica

ABEP Associação Brasileira de Empresas de Pesquisa

ACP Análise de componente Principal

ADI Valores de Ingestão Diária Aceitável

AI Ingestão Adequada ou "Adequate Intake”

ANVISA Agência Nacional de Vigilância Sanitária

AOAC Association of Official Analytical Chemists

CEASA Central de Abastecimento do Amazonas

CONAMA Conselho Nacional do Meio Ambiente

CPTA Coordenação de Pesquisas em Tecnologia de Alimentos

CV AAS Absorção Atômica com Geração de Vapor Frio

DRI Ingestão Alimentar de Referência ou "Dietary Reference Intakes"

EAR Estimativa do Requerimento Médio ou "Estimated Average Requirement"

ECD Detector de Captura de Elétrons

EPA Agência de Proteção Ambiental dos EUA

FAO Food and Agriculture Organization (Organização para a Agricultura e a Alimentação)

FNS Fundação Nacional de Saúde

FVA Fundação Vitória Amazônica

GF AAS Forno de grafite

IAEA International Atomic Energy Agency

IBGE Instituto Brasileiro de Geografia e Estatística

ICP AES Espectrometria de Emissão Atômica

ICP MS Espectrometria de Massa

INMETRO Instituto Nacional de Metrologia, Normalização e Qualidade Industrial

INPA Instituto Nacional de Pesquisas da Amazônia

IPEN Instituto de Pesquisas Energéticas e Nucleares

LAN/CRPq Laboratório de Análise por Ativação Nêutronica

LD Limite de detecção

LQ Limite de quantificação

NIMD National Institute for Minamata Disease

PNJ Parque Nacional do Jaú 
PTWI Ingestão Semanal Tolerável Provisória

RDA Recomendações de Doses ou Cotas Alimentares ou "Recommended Dietary Allowance"

UC Unidade de Conservação

UFPR Universidade Federal do Paraná

UFRJ Universidade Federal do Rio de Janeiro

UL Limite de Ingestão Máxima Tolerável ou "Tolerable Upper Intake Leve"

UNU Universidade das Nações Unidas

UV Radiação ultra violeta

WHO Organização Mundial da Saúde 


\section{CAPÍTULO 1}

\section{Introdução}

Os avanços na ciência da alimentação e nutrição têm se tornado constante nos últimos anos e, esses estudos geram resultados que devem ser usados para a melhoria da qualidade de vida da população. Estudos epidemiológicos têm fornecido evidências sobre a importância da dieta como fator de risco no desenvolvimento de inúmeras doenças e vários são os alimentos e nutrientes relacionados tanto à ocorrência quanto à prevenção de problemas crônicos em diferentes populações.

Em decorrência dessas avaliações, nos últimos anos tem aumentado sensivelmente o interesse na determinação de vários elementos essenciais e tóxicos em alimentos e dietas. Do ponto de vista nutricional o interesse está focalizado, principalmente, na adequação de nutrientes essenciais presentes nas dietas consumidas diariamente pela população (WHO, 1999; WHO, 2001; OPS, 2002; WHO, 2003). Por outro lado, toxicologistas estão preocupados com os níveis de certos elementos potencialmente tóxicos nos alimentos, como por exemplo, o $\mathrm{Hg}, \mathrm{Cd}, \mathrm{Pb}$, etc (Yuyama e col., 1997; Weihe e col., 2005). O conhecimento da composição dos nutrientes, bem como, a determinação dos níveis de ingestão de elementos tóxicos torna-se então de fundamental importância, pois através dele pode-se compor dietas especiais para grupos que desempenham atividades específicas, estipular uma dieta adequada a cada grupo populacional e diminuir a exposição a elementos nocivos à saúde.

São inúmeros os estudos que avaliam a influência dos elementos essenciais e aqueles considerados tóxicos para o organismo, atribuindo a alguns elementos traço, como crômio, cobre e selênio, efeitos benéficos nos fatores de risco associados com as doenças cardiovasculares, sugerindo que uma diminuição deste risco pode ser obtida por uma ingestão adequada destes elementos (Anderson, 1986; Alwan, 1993). Por exemplo, um estudo realizado na faculdade Joseph Fourier, na França, mostrou que a concentração de Se no sangue diminui significativamente, na fase aguda de um infarto do miocárdio e em pessoas portadoras de doenças coronárias (Tanguy e col., 2003). Outros elementos têm sido relacionados com a diminuição do risco de câncer (Reddy, 2003; Gertjan, 2004). Há evidências de que a mortalidade devido ao câncer em seres humanos é menor em regiões cujos solos são ricos em selênio (Abdulla \& Chimielnicka, 1990). 
Com relação às crianças, é conhecido também que o "status" nutricional pode influenciar no seu rendimento escolar e aumentar o risco de retardo no crescimento, o qual depende da quantidade de calorias, proteína e micronutrientes, em especial a vitamina $\mathrm{A}$, o $\mathrm{Zn}$ e o $\mathrm{Fe}$, presentes na dieta. (Alaimo e col, 2001; Abalkhail \& Shawky; 2002 e Assis \& Barreto, 2000). Atualmente são conhecidas várias doenças causadas pela deficiência de elementos traço essenciais, como por exemplo, a anemia causada pela deficiência de ferro que vem aumentando em alguns países nas últimas décadas, acometendo cerca de dois bilhões de habitantes no mundo todo (Silva e col., 2002). Contudo, pequenas deficiências de alguns elementos traço essenciais são mais difíceis de diagnosticar, mas são igualmente prejudiciais ao organismo, como a ocorrência de uma cardiomiopatia em crianças chinesas, conhecida como doença de Keshan, que foi atribuída, entre outras causas, à deficiência de Se, uma vez que a doença foi prevalente em regiões de solos pobres neste elemento (Chen \& Gao, 1993; Levander, 1994).

Por outro lado, alguns dos elementos incorporados pelo homem possuem propriedades altamente tóxicas, mesmo quando ingeridos em quantidades muito pequenas e não apresentam função metabólica, pelo menos ainda não conhecida. No entanto, muitos metais que hoje são considerados deletérios podem no futuro, ser aceitos como nutrientes essenciais tornando a diferenciação mais difícil ainda. Entrementes, os elementos considerados nocivos, como por exemplo, o $\mathrm{As}, \mathrm{o} \mathrm{Cd}, \mathrm{o} \mathrm{Pb}$ e o $\mathrm{Hg}$, que geralmente são classificados como nocivos, devido à atividade biológica ser restrita à reações tóxicas, são encontrados naturalmente no solo, na água e nos alimentos e podem afetar acentuadamente o metabolismo de alguns constituintes essenciais, tais como $\mathrm{Cu}, \mathrm{Zn}, \mathrm{Se}$, pois competem com esses elementos por ligantes do sistema biológico (Campos e col., 2002). Tal competição e a combinação com ligantes podem ter efeitos adversos na distribuição e homeostase dos elementos essenciais no organismo. Há muitos estudos realizados em animais de laboratório e em seres humanos, indicando que as deficiências nutricionais podem favorecer a absorção dos elementos tóxicos (Abdulla \& Chimielnicka, 1990; Book review, 2000; Bárány e col., 2005). Contudo, mesmo os minerais considerados essenciais do ponto de vista nutricional podem se tornar prejudiciais se ingeridos em quantidades elevadas.

O desenvolvimento e o aperfeiçoamento de técnicas analíticas têm aumentado, substancialmente, o conhecimento do papel dos nutrientes na saúde humana, bem como, sua interação com elementos considerados tóxicos, pois os nutrientes essenciais podem tornar-se limitantes pelo consumo de dietas inadequadas e também pelo desequilíbrio ambiental, acarretando um aumento da concentração dos elementos nocivos. 


\section{O projeto}

No Estado do Amazonas, há uma grande lacuna de informações, especialmente em relação à alimentação de pré-escolares da região. A dificuldade de acesso e apoio logístico, bem como sua diversidade regional com características específicas de cada um dos ecossistemas amazônicos dificultam uma avaliação nutricional nestas comunidades.

Em um projeto de pesquisa desenvolvido em parceria com o Laboratório de Nutrição e Físico-Química de Alimentos do INPA (Instituto Nacional de Pesquisas da Amazônia), Manaus, foi realizado um estudo exploratório com o objetivo de ampliar informações sobre o consumo alimentar de pré-escolares da região Amazônica, estado do Amazonas. Nesta ocasião foram avaliados alguns grupos populacionais de pré-escolares de vários municípios. O objetivo inicial era somente realizar uma avaliação nutricional das dietas dessas crianças, porém, além de ser constatada a inadequação das dietas de algumas comunidades, verificou-se também a presença de $\mathrm{Hg}$ em concentrações acima do esperado. Este fato evidenciou a necessidade de pesquisar, com mais detalhes, a possível contaminação ambiental no Parque Nacional do Jaú (PNJ), local onde as dietas das comunidades apresentaram os níveis mais altos de $\mathrm{Hg}$.

É conhecido que a desnutrição na população infantil pode agravar um quadro decorrente da exposição a elementos tóxicos, como por exemplo, o $\mathrm{Hg}$, já que crianças são particularmente sensíveis aos efeitos deletérios deste elemento, comprometendo seu desenvolvimento (National Research Council, 2000).

Reconhecendo-se o problema de exposição (natural e antrópica) ao $\mathrm{Hg}$ na região Amazônica, a presente proposta investigou não só as concentrações de $\mathrm{Hg}$ total e elementos essenciais em dietas, mas também os teores de $\mathrm{Hg}$ total e metilmercúrio ( $\mathrm{MeHg}$ ) em cabelos de préescolares da região do PNJ e comunidades próximas. Para efeito de comparação de populações diferentes dentro do Estado do Amazonas, avaliaram-se também crianças de baixa renda, residentes em bairros da cidade de Manaus. Nesse estudo, foram determinados os teores de $\mathrm{Hg}$ total e $\mathrm{MeHg}$ em cabelos de pré-escolares destas localidades e $\mathrm{Hg}$ total e elementos essenciais em algumas espécies de peixes mais consumidos por essa população de Manaus. O estudo objetivou contribuir na avaliação da exposição de alguns grupos da população brasileira - principalmente aqueles com alto consumo de peixe - pois ainda são necessários inúmeros estudos para que seja possível fornecer um quadro completo da distribuição do $\mathrm{Hg}$ total e $\mathrm{MeHg}$, bem como, a exposição da população tanto nacional como regional. Estas informações poderão subsidiar futuras ações de políticas 
públicas que visem à proteção de Parques Nacionais que são unidades de conservação que se destinam à preservação de áreas naturais com características de grande relevância sob aspectos ecológico, cênico, científico, cultural, educativo e recreativo.

O PNJ é o maior Parque Nacional do Brasil e do mundo em floresta tropical úmida contínua e intacta, portanto, medidas para a recuperação de seu sistema alterado e a obtenção do desenvolvimento sustentável são de grande relevância sócio-ambiental e exigem uma abordagem integrada que leve em conta as necessidades da população que habita o PNJ a longo prazo, como também as necessidades imediatas.

\subsection{Objetivos e motivações}

O presente estudo visou avaliar os constituintes nutricionais e $\mathrm{Hg}$ em algumas espécies de pescados e dietas, assim como fornecer um quadro parcial da distribuição do $\mathrm{Hg}$ e $\mathrm{MeHg}$ e da exposição de pré-escolares e escolares, residentes no PNJ e da cidade de Manaus, AM. Objetivo proposto frente à constatação do estudo exploratório, realizado pelo INPA, da inadequação das dietas de algumas comunidades e da indicação da contaminação por Hg no PNJ, proveniente de uma fonte não localizada e, a influência de outras comunidades nesse ecossistema.

Os objetivos específicos foram:

1) Desenvolver e validar metodologia para a determinação de $\mathrm{Hg}$ total nas amostras de cabelos, peixes e dietas e MeHg nas amostras de peixes e cabelo.

2) Desenvolver e validar metodologia para a determinação das concentrações dos minerais essenciais $\mathrm{Ca}, \mathrm{Fe}$, Na, K, Se e Zn, nas amostras de dietas e peixes.

3) Avaliar o quadro da distribuição do $\mathrm{Hg}$ e $\mathrm{MeHg}$ em cabelo nas comunidades do PNJ e cidade de Manaus.

4) Avaliar a perda de $\mathrm{Hg}$ total e outros nutrientes ( $\mathrm{Ca}, \mathrm{Fe}, \mathrm{Na}, \mathrm{K}$, Se e $\mathrm{Zn}$ ) no músculo de espécies de peixes mais consumidas na região, submetidas a três diferentes processos de cocção.

5) Contextualização ambiental dos dados levantados, de forma a fornecer uma visão espaçotemporal atualizada da contaminação por Hg na região. 
Os aspectos relevantes do trabalho podem ser analisados sob dois pontos de vista:

- A importância do trabalho do ponto de vista de saúde pública, deve-se à possibilidade de verificação da contaminação de crianças em idade pré-escolar dessa região, devido a uma possível exposição ao $\mathrm{Hg}$ (antrópica, natural ou ambas). Além do teor de $\mathrm{Hg}$ e $\mathrm{MeHg}$ tornase também de interesse, a avaliação nutricional dessas populações quanto à ingestão de elementos minerais essenciais. Vale salientar que não existe na literatura, nenhum trabalho que contemple ambas as avaliações, nutricional e à exposição ao $\mathrm{Hg}$, sendo essa contribuição extremamente importante para completar o quadro da exposição para a região.

- Com relação às metodologias empregadas, as análises de $\mathrm{Hg}$, particularmente a determinação de $\mathrm{MeHg}$, são feitas rotineiramente por muitos laboratórios internacionais, porém no Brasil poucos laboratórios estão habilitados, devido à sua complexidade. 


\section{CAPÍTULO 2}

\subsection{Problemática do mercúrio}

\section{A ameaça}

O Hg e os seus compostos são altamente tóxicos para o homem, os ecossistemas e a vida selvagem. Inicialmente considerado um problema agudo e local, a poluição pelo $\mathrm{Hg}$ é atualmente entendida como global, difusa e crônica. Doses elevadas podem ser fatais para o homem, mas mesmo doses relativamente baixas podem ter repercussões adversas graves no desenvolvimento neurológico, prejudiciais ao sistema cardiovascular, imunológico e reprodutivo. O $\mathrm{Hg}$ retarda também as atividades microbiológicas nos solos, é persistente e, no meio ambiente, pode transformar-se em $\mathrm{MeHg}$, que é a sua forma mais tóxica. O MeHg atravessa facilmente a barreira placentária, concentrando-se principalmente no cérebro, inibindo potencialmente o desenvolvimento cerebral do feto. Por essas razões, uma grande preocupação é a exposição das mulheres em idade fértil e das crianças (Diretiva, 2000).

\section{O ciclo}

Além de inodoro, o Hg é o único metal conhecido que se apresenta no estado líquido em temperatura ambiente e a $0^{0} \mathrm{C}$, é também o único elemento, além dos gases nobres, cujo vapor é monoatômico à temperatura ambiente. Recentemente, novas técnicas analíticas têm se tornado disponíveis em estudos ambientais e conseqüentemente, o entendimento da química deste elemento em sistemas naturais têm aumentado significativamente (Lindqvist e col., 1992; Feng e col. 2001; Bisinoti, 2005). O Hg pode existir em um grande número de formas químicas com diferentes propriedades. A conversão entre essas diferentes formas proporciona a base para o modelo de distribuição em ciclos locais e globais e, seu enriquecimento biológico nos organismos. Os grupos mais importantes são: $\mathrm{Hg}$ elementar, as espécies de Hg inorgânico e as espécies de Hg orgânico (UNEP, 2002). 
Processos naturais como a ressuspensão de partículas do solo pelos ventos, salsugem ${ }^{1}$, emanações vulcânicas, queimadas e emanações do solo e águas superficiais podem contribuir para as emissões naturais do $\mathrm{Hg}$. O intemperismo também pode disponibilizar o metal contido em rochas, entretanto, a atividade humana tem contribuído muito para o aumento dos níveis globais de $\mathrm{Hg}$.

Contudo, embora o mecanismo de deposição atmosférica seja muito importante e muitas vezes responsável pela contaminação em regiões remotas e não industrializadas, deve-se também, levar em consideração os mecanismos que envolvem o ciclo biogeoquímico do $\mathrm{Hg}$ em solos e corpos aquáticos. $\mathrm{O} \mathrm{Hg}$ liberado para a atmosfera (fontes naturais ou antrópicas) na forma de $\mathrm{Hg}^{0}$ sofre oxidação na interface sólido-líquido (neblina, gotículas de chuva) e por meio de reações mediadas pelo ozônio e raios ultravioletas torna-se $\mathrm{Hg}^{2+}$. Este retorna ao ambiente aquático e terrestre carreado pela água da chuva ou adsorvido a pequenas partículas. O cátion mercúrico também pode se originar do rompimento da ligação carbono-mercúrio de compostos orgamercuriais, por meio de processos químicos ou biológicos. No ambiente aquático, $\mathrm{o}_{\mathrm{Hg}^{2+}}$ é adsorvido preferencialmente na superfície dos sedimentos, ácidos húmicos, material particulado e argilas por processos de co-precipitação e co-reação, podendo formar grande quantidade de complexos e de quelantes com o material orgânico (Mucci e col., 1995). Nas camasdas superiores

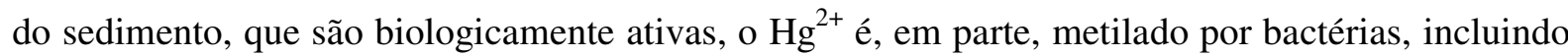
as sulfato redutoras, transformamdo-se em metilmercúrio e depois a etilmercúrio na interface águasedimento e também, no perifiton ${ }^{2}$ das macrófitas aquáticas. $\mathrm{O} \mathrm{MeHg}$ é rapidamente absorvido pelos organismos marinhos e desta forma será bioacumulado e biomagnificado ao longo da cadeia trófica. Logo, os organismos de topo de cadeia apresentarão as maiores concentrações de $\mathrm{Hg}$ total e MeHg. Em menor extensão, o MeHg é também demetilado a $\mathrm{Hg}^{2+}$ e posteriormente reduzido a $\mathrm{Hg}^{0}$, retornando a atmosfera (Azevedo, 2003). Na Figura 1 estão ilustradas as diferentes origens do Hg.

\footnotetext{
${ }^{1}$ Salsugem (do latim 'salsugine-'): lodo que contém substâncias salinas; qualidade do que é salso ou salgado.

2 Perifiton é definido como uma comunidade completa de microbiota (algas, bactérias, fungos, animais e detritos orgânicos e inorgânicos) que se encontra associada a um substrato (Salazar, 2006).
} 


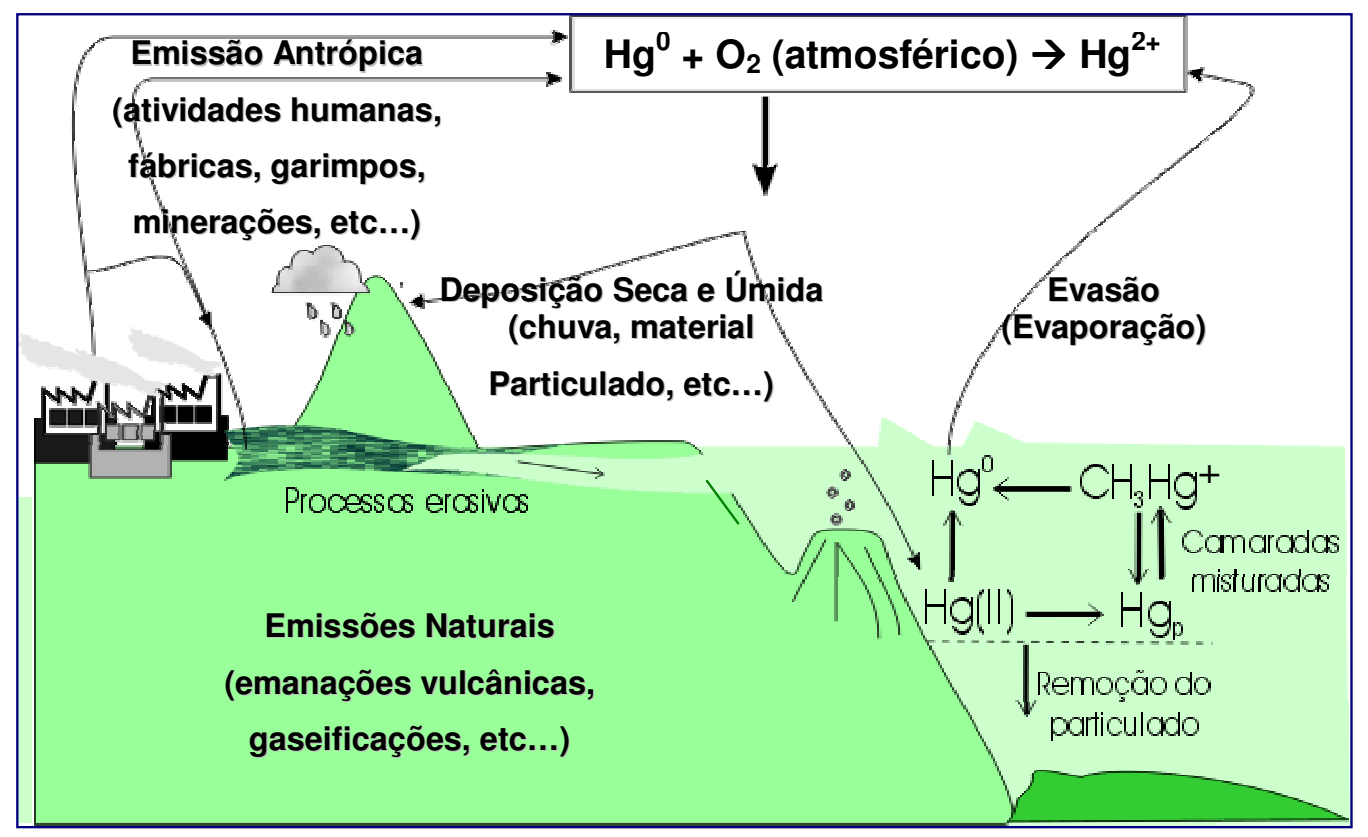

Figura 1. Origem do Hg (adaptado de Azevedo, 2003).

Como resultado de emissões antrópicas, a taxa de deposição atmosférica de $\mathrm{Hg}$ é aproximadamente três vezes maior do que no tempo pré-industrial e tem aumentado de um fator de 2-10, nas proximidades das regiões industrializadas (Hylander \& Meili, 2003). As principais fontes de poluição de $\mathrm{Hg}$, causadas pelo próprio homem, são as indústrias termoelétricas movidas a carvão, indústrias de processamento de metais, de incineração de lixo, lâmpadas fluorescentes, produção de baterias, produção de cloro, indústria de mineração e esgotos e outros resíduos podem também ser fontes de contaminação (Cetesb, 1989, 1990, 2001). Dadas as características alarmantes do quadro descrito, na maioria dos países as emissões de $\mathrm{Hg}$ de origem antrópica tiveram uma queda significativa em virtude do controle mais rígido exercido pelos órgãos governamentais, embora ainda, verifique-se concentrações elevadas deste elemento em muitas partes do mundo. Algumas são principalmente devidas a fontes locais, notadamente à extração de ouro em pequena escala na América do Sul, África e Ásia. Mas como poluente "transfronteiriço" que é, o $\mathrm{Hg}$ pode igualmente ser transportado a nível global para regiões distantes da sua fonte. Isso significa que alguma poluição de caráter local, vista à curto prazo, poderá se juntar à reserva global a longo prazo. Tal fato teve também como resultado, a contaminação de regiões com poucas ou nenhumas fontes de $\mathrm{Hg}$, como o Ártico. 
No Brasil, a extração de ouro, entre outras, é uma grande fonte de contaminação, principalmente nas regiões Amazônica e Centro-Oeste, em que o metal é extraído do minério pela amalgamação com $\mathrm{Hg}$.

Hg e a saúde

As primeiras evidências dos efeitos neurotoxicológicos do $\mathrm{Hg}$, em consequiência da ingestão materna de alimentos contaminados, foram observadas em crianças na cidade de Minamata, Japão, na década de 50, onde o MeHg liberado de uma indústria química contaminou as águas da baía local, contaminando os peixes consumidos pela população. $\mathrm{O} \mathrm{Hg}$ nos peixes está principalmente na forma de $\mathrm{MeHg}$, o qual é caracterizado por sua alta biodisponibilidade. Neste acidente, onde moluscos analisados exibiram concentrações de 11 a $40 \mathrm{mg} \mathrm{kg}^{-1}$, provocando lesões neurológicas e até mortes, o $\mathrm{Hg}$ passou a ser considerado um dos metais mais perigosos no que diz respeito à contaminação ambiental e à saúde humana. A população afetada apresentou problemas neurológicos e as crianças nascidas das mães contaminadas exibiram severas deficiências em seu desenvolvimento neural, mesmo em casos nos quais havia completa ausência de sinais clínicos nas mães. Concluiu-se, a partir disso, que o cérebro fetal é muito suscetível aos efeitos deletérios do MeHg em níveis mais baixos do que aqueles que produziam efeitos detectáveis em recém-nascidos ou em adultos (Matsumoto e col., 1965; Harada, 1977). Em 1953, a doença de Minamata foi reconhecida como uma doença neurológica e chamou a atenção do mundo todo para o problema da intoxicação por metais tóxicos (Takeucki \& Eto, 1999).

As intoxicações com Hg são evidenciadas por sintomas tais como: tremores, rigidez, ataxia entre outros (O'Reilly e col., 2000), conforme exemplificado na Figura 2, na qual o paciente apresenta contrações musculares nos dedos, sinal observado e registrado como típico nos pacientes da doença de Minamata. 


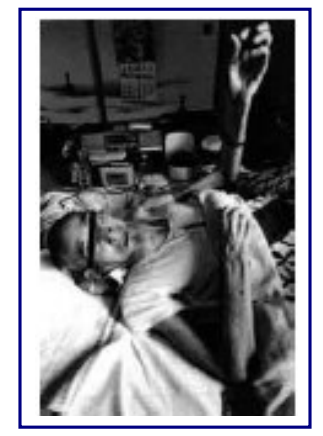

Figura 2. Paciente atendido em Minamata após contaminação com Hg. (adaptado de Dias, 2004).

Relatos similares ao de Minamata ocorreram no Iraque nos anos de 1971 e 1972, quando a população consumiu pão fabricado com farinha de trigo cujas sementes haviam sido tratadas com fungicida que continha $\mathrm{MeHg}$ em sua formulação. Estudos procurando estabelecer uma relação dose-resposta começaram então a ser realizados, utilizando-se os níveis de $\mathrm{MeHg}$ encontrados nos cabelos das mães como um indicador da exposição e relacionando-os ao desenvolvimento neural de das crianças expostas no período pré-natal (Amin-Zaki e col., 1974; Marsh e col, 1987).

Após estes episódios de intoxicação com $\mathrm{Hg}$, as pesquisas foram direcionadas na avaliação dos possíveis efeitos da exposição crônica a níveis mais baixos de $\mathrm{MeHg}$ ambiental, particularmente em crianças cuja dieta materna incluía quantidades substanciais de peixe ou outros frutos do mar. Com relação à possível carcinogenicidade do $\mathrm{Hg}$, estudos epidemiológicos realizados nas populações expostas e não expostas ao $\mathrm{Hg}$, bem como, em pessoas que sobreviveram ao acidente de Minamata, não foram conclusivos. Entretanto, outros estudos deverão ser realizados, visto que a população amostrada foi pequena, a descrição dos casos clínicos foi insuficiente e a fonte de exposição ao $\mathrm{Hg}$ não foi identificada com certeza. A carcinogenicidade do $\mathrm{MeHg}$ também foi investigada em inúmeros estudos e não foi estabelecida nenhuma relação significativa entre bioacumulação de $\mathrm{MeHg}$ e câncer. Estudos também mostraram que a exposição ao Hg pode afetar a função imunológica (National Research Council, 2000). A Agência de Proteção Ambiental dos EUA (EPA) estabeleceu um novo limite para $\mathrm{MeHg}$ de 0,1 microgramas de $\mathrm{Hg} / \mathrm{kg}$ de peso corpóreo/dia (0,1 $\mu \mathrm{g} / \mathrm{kg} / \mathrm{dia})$ (EPA, 1997). Esse valor é 4,7 vezes menor do que o valor de 0,47 $\mu \mathrm{g} / \mathrm{kg} /$ dia preconizado pela Organização Mundial da Saúde (WHO, 1990). A concentração média de $\mathrm{Hg}$ em peixes de água doce e marinhos é cerca de $0,2 \mathrm{mg} \mathrm{kg}^{-1}$. Em termos práticos, isso significa 
que uma pessoa pesando $60 \mathrm{~kg}$, em média, pode consumir somente $30 \mathrm{~g}$ de peixe por dia. É essencial, que a metodologia analítica seja capaz de distinguir entre o $\mathrm{Hg}$ total e o $\mathrm{MeHg}$, de modo a avaliar o impacto potencial de $\mathrm{Hg}$ na saúde humana, em grupos de populações expostas. A maior fonte de $\mathrm{MeHg}$ na alimentação está nos peixes, frutos do mar e derivados; para peixes comestíveis a concentração não deve exceder $0,5 \mathrm{mg} \mathrm{kg}^{-1}$ de $\mathrm{Hg}$ total, sendo que, em média, $85 \%$ se encontra na forma de MeHg. Nos EUA, a concentração média de $\mathrm{Hg}$ total encontrada nos peixes e frutos do mar é de $0,24 \mathrm{mg} \mathrm{kg}^{-1}$ para atum (principalmente enlatado), $0,46 \mathrm{mg} \mathrm{kg}^{-1}$ para camarão, $0,10 \mathrm{mg} \mathrm{kg}^{-1}$ para linguado, 0,05 $\mathrm{mg} \mathrm{kg}^{-1}$ para mexilhão, $0,25 \mathrm{mg} \mathrm{kg}^{-1}$ para caranguejo/lagosta, $0,05 \mathrm{mg} \mathrm{kg}^{-1}$ para salmão, $0,04 \mathrm{mg} \mathrm{kg}^{-1}$ para ostra, $0,42 \mathrm{mg} \mathrm{kg}^{-1}$ para truta e $0,06 \mathrm{mg} \mathrm{kg}^{-1}$ para sardinha (Nascimento \& Chasin, 2001).

No Brasil, o Conselho Nacional do Meio Ambiente (CONAMA) estabeleceu para as águas de classe I, II, e III o limite de $0,0002 \mathrm{mg} \mathrm{L}^{-1}$ de $\mathrm{Hg}$ e para águas salinas e salobras, 0,0001 $\mathrm{mg} \mathrm{L}^{-1}$. Os efluentes de qualquer fonte poluidora somente poderão ser lançados, direta ou indiretamente nos corpos de água, em níveis de $0,001 \mathrm{mg} \mathrm{L}^{-1}$ de $\mathrm{Hg}$ (Brasil, 1986). Visto a necessidade de constante aperfeiçoamento das ações de controle sanitário na área de alimentos e visando a proteção à saúde da população a Agência Nacional de Vigilância Sanitária (ANVISA), na Portaria $n^{\circ}$ 685, de 27 de agosto de 1998 também estabeleceu regulamentos técnicos sobre contaminantes em alimentos para inúmeros elementos tóxicos, incluindo o $\mathrm{Hg}$. Este Regulamento Técnico estabeleceu o limite máximo de tolerância para o $\mathrm{Hg}$ total em $1 \mathrm{mg} \mathrm{kg}^{-1}$ para peixes predadores e $0,5 \mathrm{mg} \mathrm{kg}^{-1}$ para peixes não predadores e produtos da pesca (ANVISA, 1998).

Diversos fatores afetam os níveis de $\mathrm{MeHg}$ em peixes, entre eles: a dieta e o nível trófico das espécies, sendo neste caso a espécie carnívora a que mais contribui para o acúmulo de $\mathrm{Hg}$ na forma orgânica, chegando a acumular nove vezes mais que outras espécies (Dolbec e col., 2001; Maurice-Bourgoin e col., 2000, Santos e col., 2000ª). O consumo de pequenas quantidades de peixe contaminado pode afetar acentuadamente a ingestão de MeHg em seres humanos e as preocupações referentes ao $\mathrm{Hg}$ estão baseadas em seus efeitos no ecossistema e a saúde humana (Geier \& Geier, 2003; Gilbertson, 2004).

Estudo piloto conduzido em uma população residente na ilha Aegean, Grécia, mediu o nível de $\mathrm{Hg}$ e $\mathrm{MeHg}$ em amostras de cabelo de 246 mães com o objetivo de avaliar a associação entre o consumo de peixe e o nível de $\mathrm{MeHg}$ em cabelo e estimar o potencial da exposição pré-natal das crianças. Concluiu-se que devido às fontes locais naturais de $\mathrm{Hg}$ e hábitos alimentares da população local, o qual incluía consumo regular de peixe fresco e outros frutos do mar, os fetos estavam 
sujeitos aos efeitos adversos da exposição intrauterina ao MeHg (Gibicar e col., 2006). Contudo, a eliminação do $\mathrm{MeHg}$ e o desenvolvimento de sinais e sintomas de intoxicação, dependem de fatores genéticos que, de certa forma, protegem o indivíduo da intoxicação. Estes fatores estão relacionados com o sexo, a idade, hormônios, a taxa de hemoglobina e a capacidade de indução das metalotioneínas, que podem funcionar como barreiras protetoras do cérebro e, sobretudo do cerebelo, onde o acúmulo é mais pronunciado (EPA, 1997). Sabe-se, contudo, que uma vez formado, o MeHg entra na cadeia alimentar pela rápida difusão e forte ligação à proteínas na biota aquática, atingindo suas concentrações mais altas nos tecidos de peixes no topo da cadeia alimentar, devido à biomagnificação através de níveis tróficos.

Portanto, a principal forma de exposição do homem ao $\mathrm{Hg}$ e ao $\mathrm{MeHg}$ dá-se por meio da dieta, onde este é absorvido rapidamente e, eliminado lentamente se comparado às outras formas mercuriais, apesar do ar e da água, dependendo do nível de concentração, poderem contribuir significativamente para o aumento do nível de Hg total no organismo humano. Numerosos estudos têm concluído que a maior parte, se não todo o $\mathrm{Hg}$ bioacumulado através da cadeia alimentar, é MeHg. Então, o conhecimento da concentração, transporte e dinâmica do $\mathrm{MeHg}$ em ecossistemas aquáticos tornam-se necessário para prever tanto o impacto potencial em humanos, quanto para a vida aquática (Roulet, et al., 2000; Gardfeldt e col., 2003; Gorski e col., 2003).

\section{Hg no Brasil}

A América Latina, particularmente em algumas localidades da região Amazônica, é considerada como seriamente impactada por $\mathrm{Hg}$ devido à extração de ouro, com cerca de meio milhão de pessoas diretamente envolvidas na atividade. Por anos, o $\mathrm{Hg}$ usado na mineração de ouro foi considerado ser o único causador, porém, atualmente, muitos pesquisadores acreditam que ambos os processos, naturais e antrópicos, embora operem em diferentes escalas de tempo, sejam responsáveis pela contaminação por Hg no ecossistema amazônico (Lechler e col., 2000; Fadini \& Jardim, 2001; Oliveira e col., 2001; Hylander \& Meili, 2003). Hoje, o andamento dessa investigação continua a trazer nova luz na relação entre a saúde humana e o ecossistema. De acordo com Meech e col. (1997), a poluição de Hg na Amazônia representa grave problema ambiental, pois 70 a 170 toneladas do metal são lançadas anualmente no meio ambiente pelas atividades informais de mineração de ouro, além de queimadas, em que a vegetação queimada constitui uma fonte 
primária de emissão de $\mathrm{Hg}$. Essa grande quantidade do metal sofre metilação, acumulando-se em peixes da cadeia alimentar.

Durante a última década, inúmeros estudos têm reportado que peixes de alguns rios da Amazônia estão contaminados com $\mathrm{Hg}$ ou apresentam uma concentração mais alta do que aqueles de outras regiões. Segundo Dórea (1998), as concentrações de Hg total em peixes piscívoros, onívoros e herbívoros de 12 diferentes locais do Rio Madeira (Amazônia), variaram de 0,09 a 1,45 $\mathrm{mg} \mathrm{kg}^{-1}$ dependendo da espécie considerada. Em outro trabalho, também realizado com peixes coletados no Rio Madeira, porém em área de mineração (região do Rio Beni), a concentração de $\mathrm{Hg}$ total variou de 0,33 a $2,30 \mathrm{mg} \mathrm{kg}^{-1}$ (excedendo o limite permitido), enquanto nos onívoros e naqueles que se alimentam de lama os teores variaram de 0,02 a 0,19 $\mathrm{mg} \mathrm{kg}^{-1}$ (Maurice-Bourgoin e col., 2000). Muitos outros trabalhos apresentam os teores de $\mathrm{Hg}$ total em peixes na faixa de 0,01 até $2,7 \mathrm{mg} \mathrm{kg}^{-1}$ (Pfeifer e col., 1989; Barbosa e col., 1995; Malm e col., 1997; Lechler e col., 2000; Belger, 2001).

Desta forma, pessoas que vivem ao longo desses rios e que apresentam dietas constituídas principalmente de peixes, têm níveis relativamente altos de $\mathrm{Hg}$ em seus cabelos (uma indicação da exposição ao elemento) e até recentemente, acreditou-se que a contaminação pelo metal, alastrada em uma grande superfície, resultava somente do uso de $\mathrm{Hg}$ para extrair ouro dos sedimentos de rios e solos - um método usado até os dias de hoje.

Os teores de $\mathrm{Hg}$ total em cabelo na população do Estado do Amazonas também foram avaliados em inúmeros estudos ao longo dos últimos anos e segundo Souza \& Barbosa (2000), após a análise de vários trabalhos obtiveram o teor médio de $\mathrm{Hg}$ total de $19,1 \mathrm{mg} \mathrm{kg}^{-1}$, considerado alto e merecendo especial atenção de organismos governamentais responsáveis pelo meio ambiente e saúde da população brasileira. A comparação dos níveis de $\mathrm{Hg}$ total obtidos em diversos estudos, em cabelos de crianças de algumas localidades brasileiras são mostrados na Tabela 1 e indicadores e sintomas em função da concentração do $\mathrm{Hg}$, são mostrados na Tabela 2. 
Tabela 1. Comparação do teor de $\mathrm{Hg}$ total em cabelo de crianças residentes em várias localidades do Brasil

\begin{tabular}{l|c|c|c}
\hline \multicolumn{1}{c}{ Comunidades } & \multicolumn{1}{c}{ Hg Total (mg kg ${ }^{-1}$ ) } \\
\hline & \multicolumn{1}{c}{ Média } & Intervalo & Referência \\
\hline $\begin{array}{l}\text { Brasília Legal - idade do grupo: 0- 5 anos (Estado } \\
\text { do Pará) }\end{array}$ & $5,84 \pm 4,91$ & $1,09-20,46$ & (Santos e col., 2000) \\
\hline $\begin{array}{l}\text { São Luiz do Tapajós - idade do grupo: 0- 5 anos } \\
\text { (Estado do Pará) }\end{array}$ & $21,06 \pm 14,38$ & $0,10-94,50$ & (Santos e col., 2000) \\
\hline $\begin{array}{l}\text { Waru (Indíos da Vila Dr. Tanajura) idade do grupo: } \\
\mathbf{4 - 8} \text { anos (Estado de Rondônia) }\end{array}$ & $5,6 \pm 0,8$ & $5,06-6,58$ & (Campos e col., 2002) \\
\hline $\begin{array}{l}\text { Rio Negro - idade do grupo: < 15 anos (região } \\
\text { Amazônica) }\end{array}$ & $18,52 \pm 10,04$ & $0,51-45,89$ & (Barbosa e. col, 2001) \\
\hline $\begin{array}{l}\text { Cubatão - idade do grupo: 1- 10 anos (Estado de } \\
\text { São Paulo) }\end{array}$ & $0,88 \pm 0,61$ & - & (ACPO, 2002) \\
\hline
\end{tabular}

Tabela 2. Indicadores e sintomas em função dos teores de $\mathrm{Hg}$ (Souza \& Barbosa, 2000)

\begin{tabular}{|c|c|c|c|}
\hline \multirow[b]{2}{*}{ Indicadores } & \multicolumn{2}{|c|}{ Consumo Diário de Hg } & \multirow{2}{*}{$\begin{array}{c}\text { Teores de } \mathrm{Hg} \\
\text { em cabelo }\left(\mathrm{mg} \mathrm{kg}^{-1}\right)\end{array}$} \\
\hline & $\begin{array}{c}\mu \mathrm{g} \mathrm{kg}{ }^{-1} \\
\text { do indivíduo }\end{array}$ & $\begin{array}{c}\mu \mathrm{g} / \text { indivíduo de } \\
55 \mathrm{~kg}\end{array}$ & \\
\hline Dose de referência (EPA/OMS) & 0,1 & 16,5 & 4 \\
\hline Máximo permitido (FAO/OMS) & 0,5 & 27,5 & 7 \\
\hline $\begin{array}{l}\text { Desenvolvimento anormal de } \\
\text { crianças }\end{array}$ & $0,7-1,5$ & $38,5-82,5$ & $10-20$ \\
\hline Sintoma sub-clínicos & $1,5-2,1$ & $82,5-115,5$ & $>20$ \\
\hline $\begin{array}{l}\text { Sintomas clínicos: parestesia } \\
\text { (OMS ou WHO, 1990) }\end{array}$ & $2,4-5,5$ & $132-302,5$ & $>50$ \\
\hline Ribeirinhos da Amazônia & 1,4 & 77,0 & 19,1 \\
\hline
\end{tabular}

EPA - Agência para Proteção do Meio Ambiente - EUA.

FAO - Organização para Alimento e Agricultura - Nações Unidas. 
Não obstante, considerar-se que valores entre $10-20 \mathrm{mg} \mathrm{kg}^{-1}$ em cabelo, apresentam a possibilidade do desenvolvimento anormal de crianças, conforme a Tabela 2, Santos e col. (2002), em uma tentativa de contribuir para o estabelecimento de valores de referência para os níveis de $\mathrm{Hg}$ total em cabelos e peixes da Amazônia, determinaram a concentração de $\mathrm{Hg}$ em cabelos e peixes, juntamente com a avaliação da presença de sinais ou sintomas relacionados à contaminação com $\mathrm{Hg}$ em quatro comunidades na Bacia Amazônica, consideradas não impactadas pela mineração de ouro. Neste estudo verificaram-se teores de $\mathrm{Hg}$ total nos cabelos da ordem de 4,33 $\mathrm{mg} \mathrm{kg}^{-1}(0,40-11,60$ $\left.\mathrm{mg} \mathrm{kg}^{-1}\right)$ para 321 indivíduos da localidade de Santana do Ituqui; $3,98 \mathrm{mg} \mathrm{kg}^{-1}\left(0,40-11,76 \mathrm{mg} \mathrm{kg}^{-}\right.$ $\left.{ }^{1}\right)$ para 316 indivíduos da Aldeia do Lago Grande; $5,46 \mathrm{mg} \mathrm{kg}^{-1}\left(0,37\right.$ - 49,85 mg kg$\left.{ }^{-1}\right)$ para 504 indivíduos da Vila do Tabatinga e $8,98 \mathrm{mg} \mathrm{kg}^{-1}\left(0,61-45,59 \mathrm{mg} \mathrm{kg}^{-1}\right)$ em 203 indivíduos da localidade de Caxiuanã. O consumo de peixe foi alto em todas essas comunidades, mas nenhum sinal ou sintoma relacionado à contaminação com $\mathrm{Hg}$ foi observado. Estes resultados indicaram que mais estudos deveriam ser realizados com o objetivo de se obter valores de concentração de $\mathrm{Hg}$ que poderiam ser considerados "normais" para a região Amazônica, já que os mesmos apesar de estarem acima do limite sugerido pela Organização Mundial de Saúde ${ }^{3}$, não induziram sintomas relacionados à intoxicação por mercúrio. Outro estudo, o qual avaliou as seqüelas neurotóxicas da exposição ao MeHg em um grupo de pessoas da vila do Rio Tapajós, por outro lado, sugeriu que embora possa haver certa reversibilidade da deficiência motora, as consequiências nas funções sensoriais pode ser progressiva ou irreversível (Mergler e col., 2001).

Com relação aos efeitos do $\mathrm{Hg}$ na saúde na região Amazônica, cientistas têm o foco principal na localização da fonte de $\mathrm{Hg}$ nessa região, para entender como pessoas na área estavam sendo contaminadas com $\mathrm{Hg}$ e para examinar o impacto na saúde deles. Visto que o teor de $\mathrm{Hg}$ em cabelos de pessoas que consomem peixe, nas áreas impactadas e não impactadas da Amazônia é mais alto do que trabalhadores ocupacionalmente expostos e a maioria delas não apresentarem sinais ou sintomas da contaminação por Hg (Santos e col., 2002; Dorea, 2003). Contudo, o ecossistema amazônico é muito complexo - a cadeia alimentar, por exemplo, é maior e mais complexa do que em qualquer outra região brasileira. Por essa razão, são necessários mais estudos para desenvolver um quadro completo de como o $\mathrm{Hg}$ comporta-se nesse ambiente.

A importância do peixe na dieta das populações da Amazônia que residem ao longo dos rios e áreas alagadas, tem sido previamente documentada. Há vários grupos de pesquisadores estudando a poluição por $\mathrm{Hg}$, a fonte de contaminação e seus efeitos na saúde humana nessa região (Malm e col., 1995; Hacon e col. , 1997; Boischio \& Henshel, 2000; Santos e col. 2000; Santos e col., 2000a; Dolbec e col., 2001; Campos e col., 2002; Santos e col., 2002; Pestana \& Formoso, 2003; Dórea e

\footnotetext{
${ }^{3} \mathrm{O}$ valor de $50 \mathrm{mg} \mathrm{kg}^{-1}$ de $\mathrm{Hg}$ encontrado em cabelos de grupos com alto consumo de peixe, já está associado a 5\% de risco de danos neurológicos em adultos (WHO, 1990).
} 
col, 2005 e Dorea e col., 2006). Felizmente para as pessoas locais, que suprem suas necessidades protéicas a partir do consumo de peixe, a redução da exposição ao Hg não significa se abster deste alimento. Há um grande número de espécies de peixes nos rios dessa região, que bioacumulam $\mathrm{Hg}$ em quantidades variadas.

\section{Biomarcadores para uma monitoração sistemática}

Vários organismos vêm sendo utilizados em estudos ambientais como biomonitores de contaminação por metais tóxicos (Carvalho e col., 1993). Estes organismos possuem a capacidade de acumular metais em altas concentrações, muitas vezes superiores àquelas encontradas na água, participando assim, na dinâmica destes poluentes (Lacerda e col., 1985).

O emprego de organismos vivos vegetais ou animais de ecossistemas, que denunciam precocemente a contaminação por $\mathrm{Hg}$, seja porque são concentradores do metal, seja porque evidenciam mais cedo seus efeitos tóxicos, pode ser de grande valia no sentido de que, funcionando como sentinelas avançadas, informam sobre a evolução da poluição. Tais organismos, portanto, são verdadeiros bioindicadores da contaminação ambiental e, uma vez identificados, podem ser adotados em programas permanentes de vigilância ecotoxicológica (Azevedo, 2003).

Por outro lado, a preocupação em evitar o surgimento de doenças decorrentes da exposição de indivíduos a agentes químicos no meio ambiente, conduziu à tomada de medidas de prevenção. Estas são a base da monitoração biológica e consistem em verificar se a concentração destes agentes ou de seus metabólitos no organismo de uma população estudada está dentro dos níveis estabelecidos por órgãos governamentais ou pela comunidade científica. Particularmente com relação ao Hg, estes biomarcadores (IBEs, Indicadores Biológicos de Exposição Humana) podem ser utilizados para determinar a exposição individual ao $\mathrm{MeHg}$ através da sua própria determinação em diferentes constituintes do organismo, principalmente em cabelos, urina e sangue (Grandjean e col., 1994, 2002).

A concentração sanguiínea de $\mathrm{Hg}$ reflete exposição ao Hg orgânico e inorgânico, podendo ser influenciada pelo consumo de alimentos contaminados. O Hg permanece na corrente sangüínea apenas alguns dias após a exposição, devendo esse teste ser feito precocemente. Estes ensaios são muito utilizados para detectar exposições recentes (EPA, 2005).

A concentração de $\mathrm{Hg}$ em uma urina de $24 \mathrm{~h}$ pode refletir tanto exposições recentes como eliminações renais continuadas de cargas tecidulares acumuladas. O valor de concentração urinária 
de $\mathrm{Hg}$ de $50 \mu \mathrm{g} \mathrm{g}^{-1}$ de creatinina foi proposto por especialistas e endossado pela OMS, como o limite aceitável para exposições crônicas ao $\mathrm{Hg}$. Estudos recentes encontraram sintomas subclínicos, como mudanças em enzimas urinárias, já em concentrações de $35 \mu \mathrm{g} \mathrm{g}^{-1}$ (EPA, 2005). Amostras de urina não são comumente utilizadas para medir exposições individuais ao $\mathrm{MeHg}$, pois pouca quantidade deste metal é excretada por esta via. Ao contrário do que se verifica com o $\mathrm{Hg}$ inorgânico, o MeHg é excretado principalmente pelas fezes, existindo na eliminação uma fase inicial de declínio rápido, seguido de outra lenta (Azevedo, 2003).

Para avaliações da exposição ao MeHg pela dieta, amostras de cabelo do indivíduo exposto são mais utilizadas, pois o teor de mercúrio no cabelo é proporcional à concentração no sangue e uma vez incorporada ao fio, esta concentração não se modifica (WHO, 1990). O tecido capilar tende a acumular minerais biológicos e elementos tóxicos em sua estrutura protéica e é considerado bom indicador biológico da contaminação por alguns desses elementos prejudiciais à saúde.

A análise capilar reflete um maior tempo de exposição ao $\mathrm{Hg}$, possibilitando avaliar a concentração deste elemento através do tempo (Pascalicchio, 2002), apesar das opiniões contrárias quanto à utilização do cabelo como indicador biológico fiel da exposição de indivíduos. Segundo alguns pesquisadores, o teor de $\mathrm{Hg}$ em cabelos não seria um indicador exato da exposição a este elemento, pois as análises de cabelo não podem ser padronizadas a fim de fornecerem uma informação significativa a respeito da contaminação de um grupo populacional e estariam sujeitas a inúmeras interferências (Baratz, 2005).

Contudo, desde 1980 a EPA recomenda o cabelo como um dos tecidos de eleição para a determinação de metais tóxicos em seres humanos e a WHO em 1990, cita o cabelo como um bom indicador diagnóstico para o $\mathrm{Hg}$, especialmente o $\mathrm{MeHg}$, assim como para o arsênio (As) e possivelmente também para o chumbo $(\mathrm{Pb})$ e o tálio $(\mathrm{Tl})$.

Kehrig e col. (1997) demonstraram a precisão e validade da análise toxicológica de $\mathrm{Hg}$ em amostras de cabelo, por meio de estudo interlaboratoriais. Foi utilizado o protocolo desenvolvido pelo National Institute for Minamata Disease (NIMD) e adaptado na Universidade Federal do Rio de Janeiro (UFRJ), em estudo comparativo das mesmas amostras processadas por esses dois laboratórios (NIMD e UFRJ), tendo sido o resultado das análises comparado e analisado estatisticamente pela International Atomic Energy Agency (IAEA). Foram utilizadas amostras de cabelo coletado da população ribeirinha do rio Tapajós, população exposta à contaminação por MeHg e Hg inorgânico, apresentando um alto teor médio de MeHg nas amostras de cabelo de 10 $\mathrm{mg} \mathrm{kg}^{-1}$. A determinação do MeHg nas amostras de cabelo foi realizada por cromatografia gasosa, empregando-se detector de captura de elétrons (ECD), apresentando boa precisão e exatidão quando 
os valores obtidos foram comparados com materiais de referência da IAEA. Através do exercício de intercomparação, obteve-se também, significativa correlação entre os valores obtidos entre os dois laboratórios (NIMD e UFRJ). Os resultados desse estudo também apresentaram, por meio da análise de cabelo, uma relação entre a contaminação ambiental por $\mathrm{Hg}$ e $\mathrm{MeHg}$ e hábitos alimentares da população amazônica.

Em outro estudo realizado em Quebec, Canadá, com apoio da WHO, delineou-se indícios que tudo que é ingerido ou respirado podem se fixar no cabelo. Portanto, a análise mineral do cabelo pode ser utilizada para detectar a contaminação de substâncias como As e o Hg (Watts, 2006). Este mesmo autor questiona os apontamentos feitos por Baratz (2005) em seu artigo intitulado: “Dubious Mercury Testing”. Em sua resposta ao Dr. Baratz, argumenta que o cabelo por ser um tecido queratinizado e constituído por proteínas, fica exposto ao ambiente metabólico interno do organismo, incluindo o sangue, linfa e fluidos extracelulares. Depois de absorvido, o $\mathrm{MeHg}$ acessa o folículo capilar por meio da corrente sangüínea que banha a raiz capilar. Assume-se que o teor de $\mathrm{Hg}$ no cabelo corresponde proporcionalmente à concentração sangüínea, refletindo a forma orgânica do $\mathrm{Hg}$, mas também, por se saber que a taxa de crescimento do cabelo é de cerca de $1 \mathrm{~cm}$ por mês, avaliar as condições de contaminação sob o aspecto evolutivo ao longo dos meses (Barbosa e col., 1998).

Apesar de não ter validade como elemento de diagnóstico laboratorial nos casos de intoxicação aguda, posto que a deposição do $\mathrm{Hg}$ não se processa imediatamente após a absorção, é particularmente útil para o levantamento do grau de exposição ao $\mathrm{MeHg}$ veiculado por alimentos contaminados, por meio da análise de cabelo, a qual guarda o histórico dessa exposição (Holsbeek e col., 1996; Castoldi e col., 2003). Outras vantagens que podem ser citadas, com relação ao uso do cabelo para monitoração biológica dos metais tóxicos, referem-se ao fato de: não ser invasivo, de fácil armazenamento, mantém a estabilidade durante este período e pode acumular altas concentrações de metais tóxicos. Contudo, é necessário observar que a contaminação externa, a tintura, os descolorantes e alguns tipos de xampus podem alterar os resultados e deveriam ser levados em consideração em estudos epidemiológicos.

$\mathrm{O}$ teor de $\mathrm{Hg}$ no cabelo de $6 \mathrm{mg} \mathrm{kg}^{-1}$ corresponde à ingestão semanal de $\mathrm{MeHg}$ estabelecida, provisoriamente, como tolerável pela WHO e $2 \mathrm{mg} \mathrm{kg}^{-1}$ corresponde ao valor comumente encontrado em população não exposta (WHO, 1990). 


\subsection{O Parque Nacional do Jaú}

O Parque Nacional do Jaú (PNJ), Sítio do Patrimônio Natural Mundial da Unesco, é uma Unidade de Conservação (UC) criada em 1980 e situa-se entre as coordenadas $1^{0}$ e $3^{0} \mathrm{~S}$. e $61^{0} 30^{\prime}$ e

$64^{0}$ O., no Estado do Amazonas, ocupando uma faixa de aproximadamente $250 \mathrm{~km}^{2}$, posicionada no divisor de águas rio Negro-Solimões entre os municípios de Novo Airão e Barcelos, aproximadamente a $200 \mathrm{~km}$ a noroeste de Manaus.

É o maior Parque Nacional do Brasil e o maior parque do mundo em floresta tropical úmida e intacta. O nome Jaú, oriundo do Tupi (ya'ú), denomina um dos maiores peixes brasileiros e também o rio que banha o Parque (Figura 3). A zona de transição, também demarcada na Figura 3, foi definida a partir da bacia de drenagem dos rios que correm para dentro da Unidade, das localidades de interesse histórico que ajudam na interpretação do ambiente e das comunidades que estão diretamente envolvidas nas políticas do Parque.

Ab’Saber (1977) apud FVA (1998), divide a América do Sul em seis grandes domínios morfoclimáticos baseando-se na distribuição da pluviosidade e dos grandes grupos vegetacionais (cerrado, charco, florestas, etc.) e o PNJ, segundo essa classificação está localizado no Domínio Equatorial Amazônico, que coincide com as áreas de florestas baixas da Amazônia. Esse domínio é caracterizado por um clima quente e úmido, com as precipitações pluviométricas anuais variando de $2.000 \mathrm{~mm}$ a $2.950 \mathrm{~mm}$. 


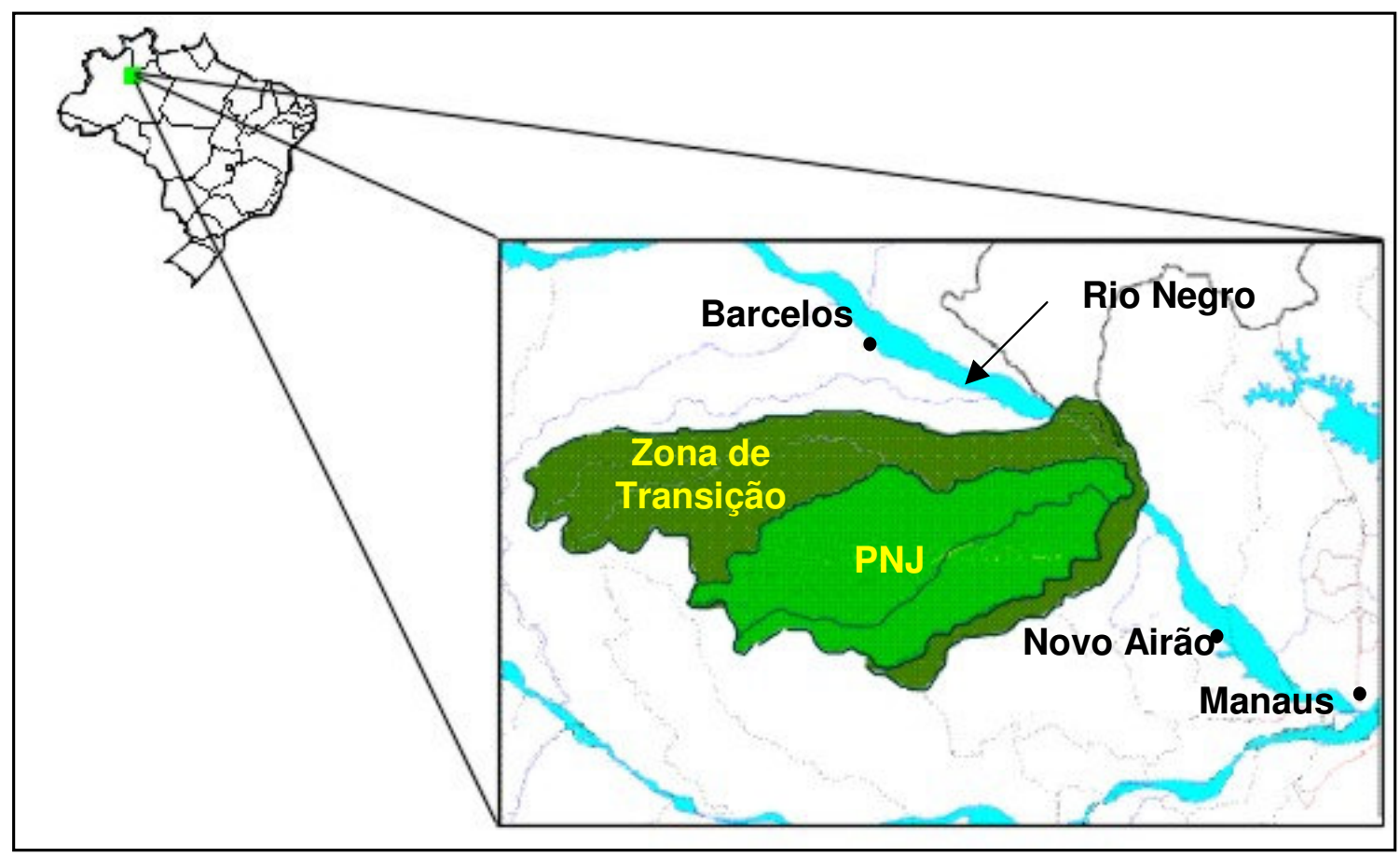

Figura 3. Mapa do Parque Nacional do Jaú (FVA, 1998).

No que diz respeito à distribuição de plantas, várias divisões têm sido propostas para classificar as regiões fitogeográficas da Amazônia. Segundo Prance (1977) apud FVA (1998), o PNJ teria seus limites incluídos na região fitogeográfica de Manaus. Dados preliminares coletados por pesquisadores indicam que certas espécies de plantas e animais não estão distribuídas de modo homogêneo no Parque. Algumas espécies estão restritas à região oeste do PNJ, enquanto outras só são encontradas nas regiões próximas à nascente do rio Jaú.

\section{Área de influência}

Os três municípios que influenciam diretamente o PNJ são Manaus, Novo Airão e Barcelos. Esses municípios ilustram a dinâmica social regional, com áreas de grande crescimento populacional, a exemplo de Manaus, e áreas que chegaram até a apresentar decréscimo populacional na década de 1970, como é o caso de Novo Airão. O município de Manaus tem uma influência indireta sobre o PNJ, em particular por ser o ponto centralizador da comercialização dos produtos extrativistas da região e o maior mercado consumidor do estado. De forma mais direta, a acariquara, madeira dessa árvore utilizada pela estatal Eletronorte para postes de iluminação pública e suporte da rede elétrica, é em parte procedente do PNJ. No período do verão, há também o fluxo 
de pescadores de Manaus para o Parque, geralmente com autorização para turismo local (FVA, 1998).

\section{A população do PNJ}

A criação desta UC não considerou o fato da área ser habitada por antigos moradores, fator que trouxe sérios problemas, pois não havendo como remover as famílias do local, as atividades praticadas por elas se contrapunham aos interesses conservacionistas. A lei é clara com relação à presença humana em UCs de uso indireto, porém a realidade é outra na maioria das UC's da América do Sul. Segundo Oliveira \& Anderson (1999), em 86\% delas existem moradores ocupando a área há séculos e sobrevivendo do uso dos recursos naturais. No PNJ a situação não foge à regra, a presença humana no local data de alguns séculos atrás.

No território do Parque, vivem menos de 900 habitantes, reunidos em 143 grupos domésticos, dos quais $47 \%$ estão vivendo em sete comunidades. Em vinte anos, os registros oficiais e dados científicos indicam uma diminuição progressiva da população que historicamente viveu na área do PNJ desde sua decretação como Unidade de Conservação (Tabela 3).

Da maioria dos moradores que vivem no PNJ, 55\% são oriundos de outras localidades do estado do Amazonas, 37\% nasceram no Parque e os outros $8 \%$ são procedentes das regiões Norte e Nordeste. A taxa de fecundidade (número de filhos nascidos vivos somado ao número de filhos nascidos mortos) é em média de sete filhos por mulher, número considerado alto, porém, a expectativa de vida é bastante limitada devido aos contínuos riscos a que são submetidos e às condições de saúde bastante precárias (FVA, 1998). 
Tabela 3. Evolução da densidade demográfica na área do PNJ, AM (FVA, 1998)

\begin{tabular}{c|c|c|c}
\hline Ano & № de famílias & № de moradores & Densidade $\left(\mathbf{h a b} . \mathbf{k m}^{2}\right)$ \\
\hline $\mathbf{1 9 7 7}$ & - & 3536 & 0,13 \\
\hline $\mathbf{1 9 9 0}$ & 225 & 1530 & 0,07 \\
\hline $\mathbf{1 9 9 2}$ & 167 & 1019 & 0,04 \\
\hline $\mathbf{1 9 9 6}$ & 143 & 886 & 0,04 \\
\hline
\end{tabular}

A população que habita o PNJ, assim como a de outras regiões da Amazônia, busca quase sempre se estabelecer às margens dos rios e de seus tributários. A proximidade da água e dos recursos da floresta possibilita as condições necessárias para a subsistência do grupo doméstico (Figura 4).

A ocupação espacial da população está vinculada à disponibilidade de recursos, ao lugar onde a família se estruturou e à proximidade dos parentes, dos amigos e/ou de comunidades que compõem histórias de uma ou mais famílias. Os moradores do PNJ são ribeirinhos que praticam a pesca ornamental e de subsistência, fazem os roçados para a agricultura familiar e o pequeno extrativismo.

O sistema de saúde, assim como o sistema educacional, apresenta problemas: o hospital mais próximo está na cidade de Novo Airão. Em função desta realidade, os moradores buscam alternativas nos conhecimentos tradicionais, no uso das ervas medicinais de que dispõe a floresta, na reza do rezador, nas mãos sábia da parteira, ou mesmo na orientação do padre e do pastor.

A atuação do Estado tem se limitado a visitas esporádicas da Fundação Nacional de Saúde (FNS) por meio de ações preventivas, como borrifação das casas e curativas, como o diagnóstico, por meio da coleta de sangue daqueles que apresentam os sintomas da malária e o respectivo tratamento (FVA, 1998). 


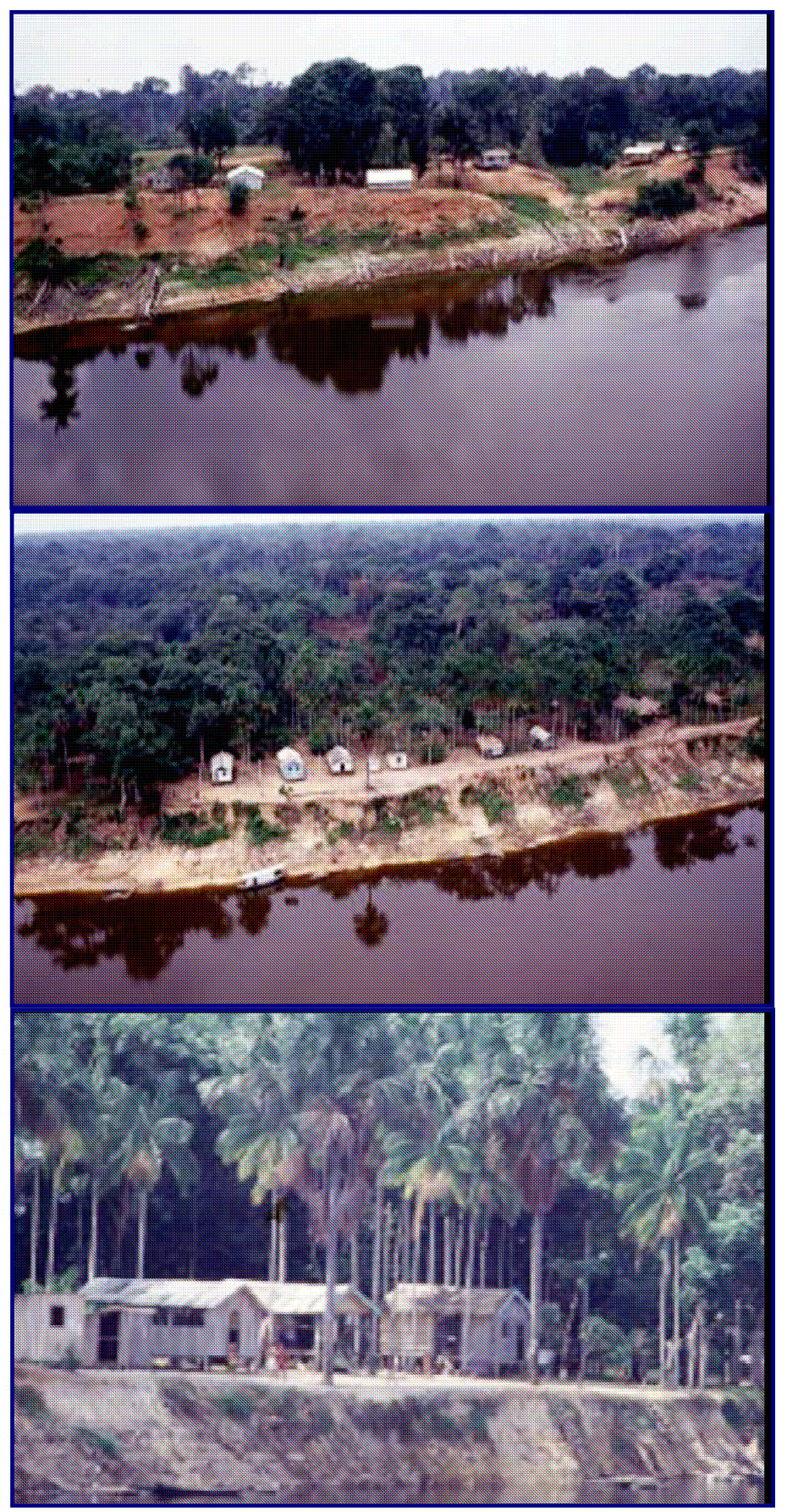

Figura 4. Vista área de comunidades do PNJ (FVA, 98). 


\section{O uso dos recursos naturais no PNJ}

Os produtos mais utilizados para o consumo direto do grupo doméstico ou para a comercialização classificam-se em: obtidos pelo extrativismo vegetal, como o cipó-titica, o cipó timbó-açu, a castanha, a copaíba, o breu e a madeira; os obtidos do extrativismo animal, como os quelônios, os peixes ornamentais e a caça; e ainda aqueles obtidos pela atividade agrícola, como a farinha e a banana. O conhecimento das atividades de subsistência, como a agricultura e o extrativismo, também foi e continua sendo transmitido às novas gerações. Os habitantes do PNJ buscam, nestas atividades laborais a sobrevivência dos grupos domésticos, como faziam seus antepassados. As atividades extrativistas exercidas pelos habitantes do Jaú representam parte de sua base econômica, onde o material extraído da fauna, da flora e da produção agrícola é comercializado pelo sistema de aviamento ${ }^{4}$. Essas atividades apontam estudos, correspondem a um impacto ambiental em apenas $0,5 \%$ da área. Para manter este patamar, a Fundação Vitória Amazônica (FVA) está desenvolvendo com os moradores o "Programa de Alternativas Econômicas", focado nos municípios de Barcelos e Novo Airão e que visa melhorar as condições sócio econômicas da população local e a sustentabilidade do Parque (Instituto Sócio Ambiental, 2003). A Figura 5 traz a utilização dos recursos naturais disponíveis no PNJ pela população tradicional e a qual está vinculada às necessidades de subsistência do grupo doméstico. No quadro A o morador prepara a palha-branca para ser usada na cobertura de casas; no quadro B bacias com ácara disco, peixe ornamental endêmico da região que possui alguma demanda no exterior; o quadro $\mathbf{C}$ traz a foto de quelônios que são usados na base alimentar dos amazonenses, sendo um dos recursos mais críticos utilizados no Parque; o quadro D mostra uma piaba de cipó-titica, produto utilizado na confecção de artesanato e no quadro $\mathbf{E}$ aparecem as castanhas, as quais são encontradas com relativa abundância, usada na base alimentar do morador e possível alternativa econômica a ser explorada.

Os levantamentos agrícolas realizados no PNJ fornecem dados a partir do mapeamento e do inventário dos cultivos desenvolvidos, das excursões e das entrevistas e dos croquis das roças do Jaú. Os relatórios científicos mostram como os moradores cultivam com base em seus costumes e tradições e ressaltam que cada morador tem uma maneira própria de cuidar das roças, herdadas de seus pais.

\footnotetext{
${ }^{4}$ Sistema de aviamento - consiste na manutenção da dependência ao patrão por meio do endividamento.
} 
Nas roças cultivam-se não só a mandioca, mas também outros plantios, como banana (o segundo produto mais cultivado), cana-de-açúcar, ananás, caju, milho, café, pimenta e diversos tubérculos (batata, cará e ariá). A mandioca ocupa $90 \%$ da área plantada e é dela que se fabrica a farinha, a tapioca, a goma, o beiju e o tucupi (molho de cor amarela extraído da raiz da mandioca brava), base importante de alimentação da região (FVA, 1998). A farinha não é só fonte de rendimento dos produtores, mas o alimento principal de subsistência da unidade familiar, que tem como base de produção anual a quantidade de sacos de farinha produzida em uma quadra, ou seja, o equivalente a 60 ou 65 sacas. Apesar de compor a base alimentar da população, a farinha é um alimento exclusivamente energético, paupérrimo em proteínas, sais minerais e vitaminas. Entretanto, é um dos produtos que mais vem sendo comercializado pelos regatões em troca de mercadorias ou para pagar dívidas (FVA, 1998). 

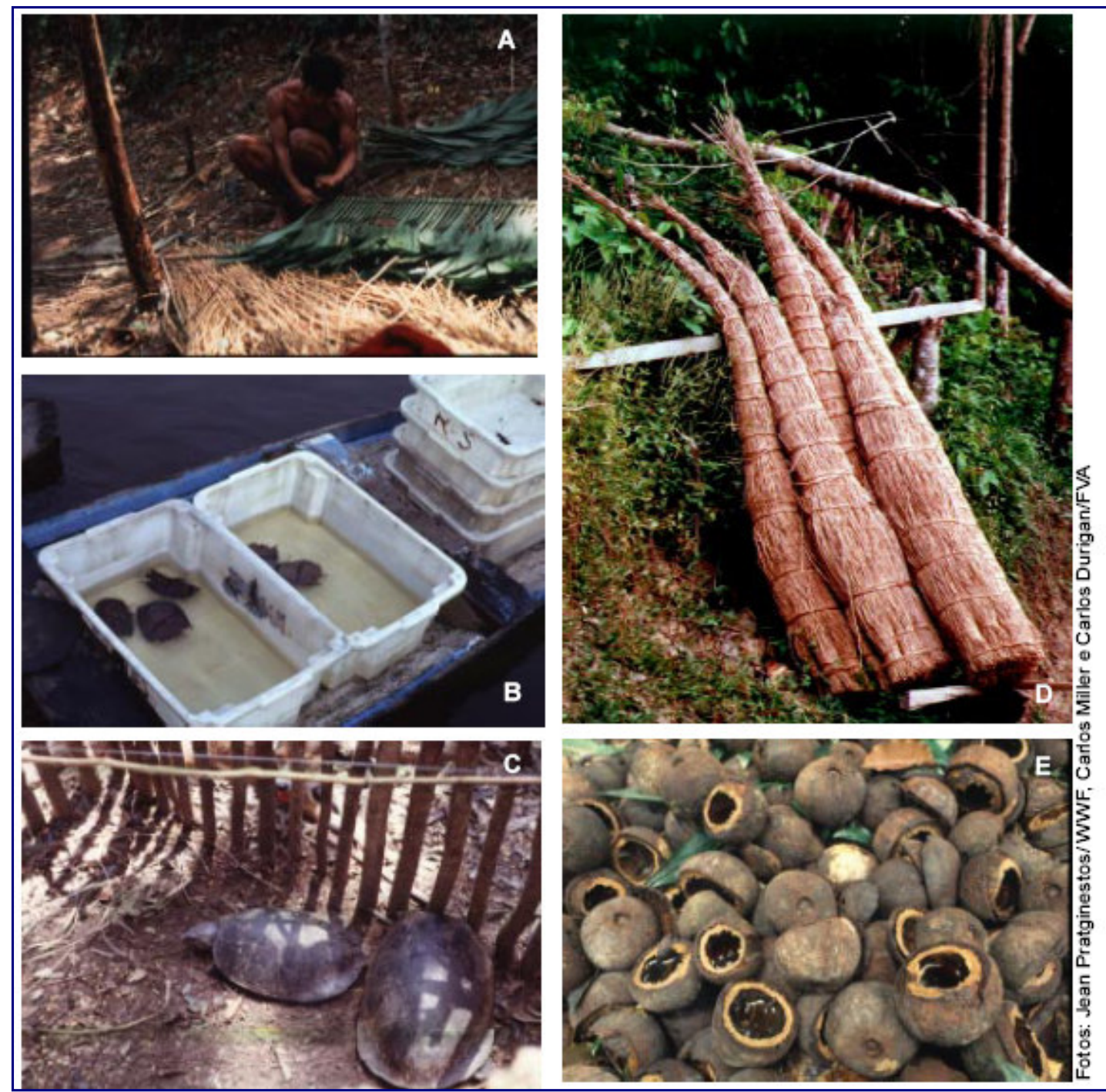

Figura 5. Utilização dos recursos naturais disponíveis no PNJ (FVA, 98).

A principal fonte de proteína animal para os ribeirinhos que habitam o PNJ são os peixes, seguidos pelos mamíferos, depois pelos répteis (sobretudo quelônios) e, em menor proporção, as aves (Figura 6). A riqueza de espécies utilizadas é considerada alta em comparação com estudos semelhantes na região amazônica e pode ser encarada como forma de adaptação a um sistema com baixa produtividade e densidade, mas por outro lado rico em espécies (Pezzuti, 2003). 


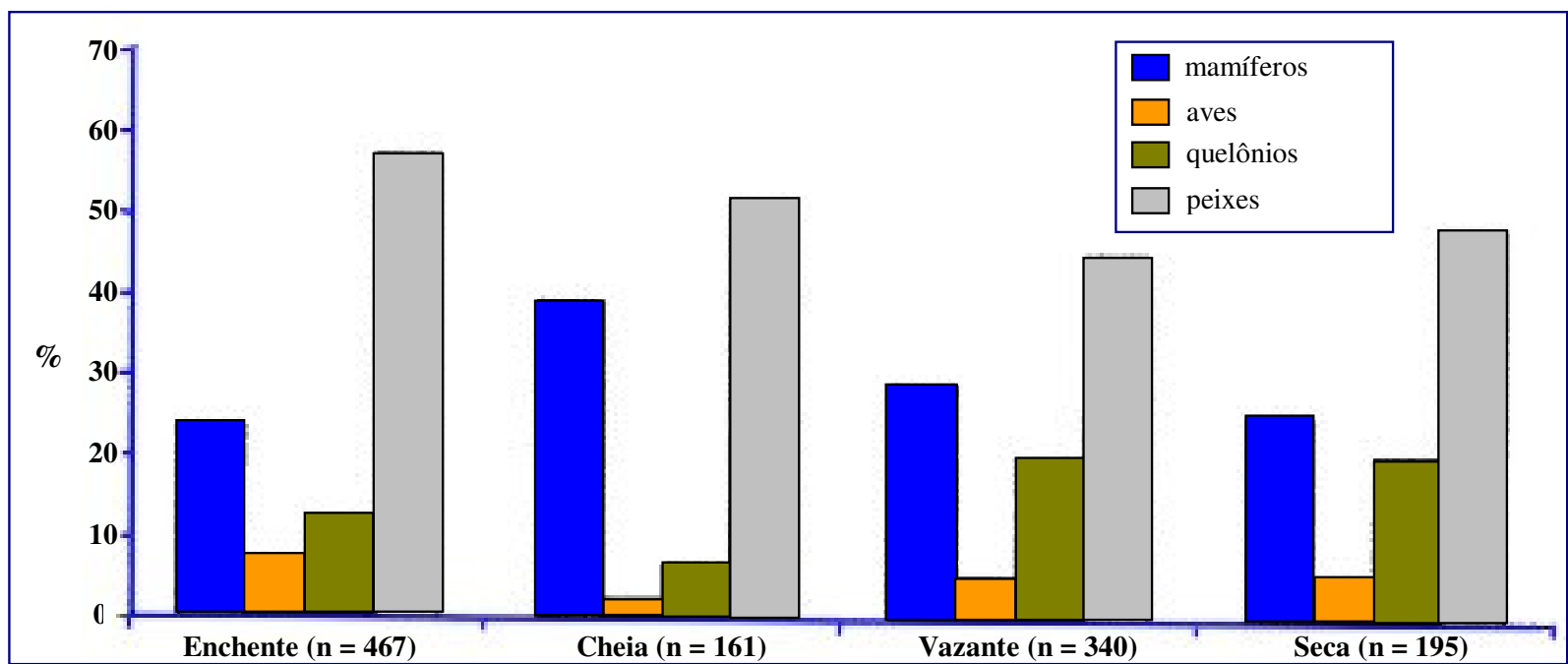

Figura 6. Proporção do consumo de animais em diferentes épocas do ano pelos moradores do PNJ, entre 1995 e 2002 (dados obtidos por meio de monitoramento com calendário de caça e entrevistas (adaptado de Pezzuti, 2003)).

Entretanto no PNJ, as 263 espécies de peixes catalogadas reforçam a necessidade de quantificação não só dos elementos minerais essenciais, mas também dos considerados tóxicos como o $\mathrm{Hg}$ e o MeHg, nas espécies mais consumidas pela população local, proposta do presente estudo, visto que a dificuldade de acesso a produtos industrializados, tornam os peixes a principal fonte de proteínas da população.

\section{O rio Jaú}

Uma das peculiaridades mais extraordinárias do PNJ é o fato de ser esta a única Unidade de Conservação do Brasil que protege totalmente a bacia de um rio extenso (aproximadamente 450 km) e volumoso - rio Jaú, preservando ecossistemas de águas pretas. Este Parque constitui uma importante amostra dos ecossistemas amazônicos, sendo o rio Jaú afluente da margem direita do rio Negro, o qual corta a cidade de Manaus (FVA, 98).

É conhecido que ecossistemas de águas escuras são exemplo de terras inundáveis que possuem características biogeoquímicas que favorecem a metilação do $\mathrm{Hg}$ na biota aquática. As 
condições ideais para a metilação do $\mathrm{Hg}$ nestas águas estão relacionadas à riqueza em matéria orgânica e nutrientes que propiciam os processos microbiológicos, acidez e a baixa condutividade e altas concentrações de carbono orgânico dissolvido que fomentam a bioacumulação do MeHg na cadeia alimentar aquática (Silva Fosberg e col., 1999; Fadini \& Jardim, 2001).

\subsection{Manaus}

A cidade de Manaus originou-se de um aldeamento indígena, formado em torno da Fortaleza de São José da Barra, em 1669, construída para evitar uma invasão de holandeses aquartelados no atual Suriname e garantir o domínio da coroa portuguesa na região. Em 1832, o lugarejo, sob a denominação de N. S. da Conceição da Barra do Rio Negro, foi elevado à categoria de Vila. Em 1848, a Vila da Barra foi elevada à categoria de Cidade, com o nome de Cidade da Barra do Rio Negro. Só em 1856, finalmente, a cidade recebeu o nome de Manaus, em homenagem à nação indígena dos Manao - Mãe dos Deuses - o mais importante grupo étnico habitante da região (Prefeitura de Manaus, 2006).

Foram marcantes os anos compreendidos entre 1890 e 1910, conhecido como "período áureo da borracha", em que o Estado do Amazonas abasteceu o mundo de borracha natural. Nesse período, a cidade experimentou um grande crescimento urbano e econômico que deixou como herança vasto patrimônio arquitetônico de procedência européia. Manaus foi uma das primeiras cidades brasileiras a contar com luz elétrica, galerias pluviais, tratamento de águas e esgotos, serviço de bondes elétricos e inaugurou a primeira Universidade, em 1909. O porto de Manaus também data desse período. Ele é flutuante, acompanha a enchente e a vazante dos rios, foi importado da Inglaterra, assim como vários outros prédios públicos. Após esse período, a cidade passou por várias décadas de estagnação, rompida pela reformulação do projeto Zona Franca de Manaus, que criou o atual modelo de desenvolvimento (Prefeitura de Manaus, 2006).

Localizada na região Norte do Brasil, Manaus é a capital do Estado do Amazonas e portão de entrada para a maior reserva ecológica do planeta: a Floresta Amazônica. Às margens do Rio Negro entrecortada por igarapés, Manaus é privilegiada pela beleza da paisagem natural. O acesso é feito principalmente por via fluvial ou aérea. As viagens fluviais ou rodoviárias exigem grande disponibilidade de tempo, devido à disposição geográfica da cidade. A área urbana de Manaus situa-se entre as coordenadas $2^{\circ} 57^{\prime}$ e $3^{\circ} 10^{\prime}$ latitude Sul e 59 $53^{\prime}$ e $60^{\circ} 07^{\prime}$ longitude Oeste (Figura 7). 


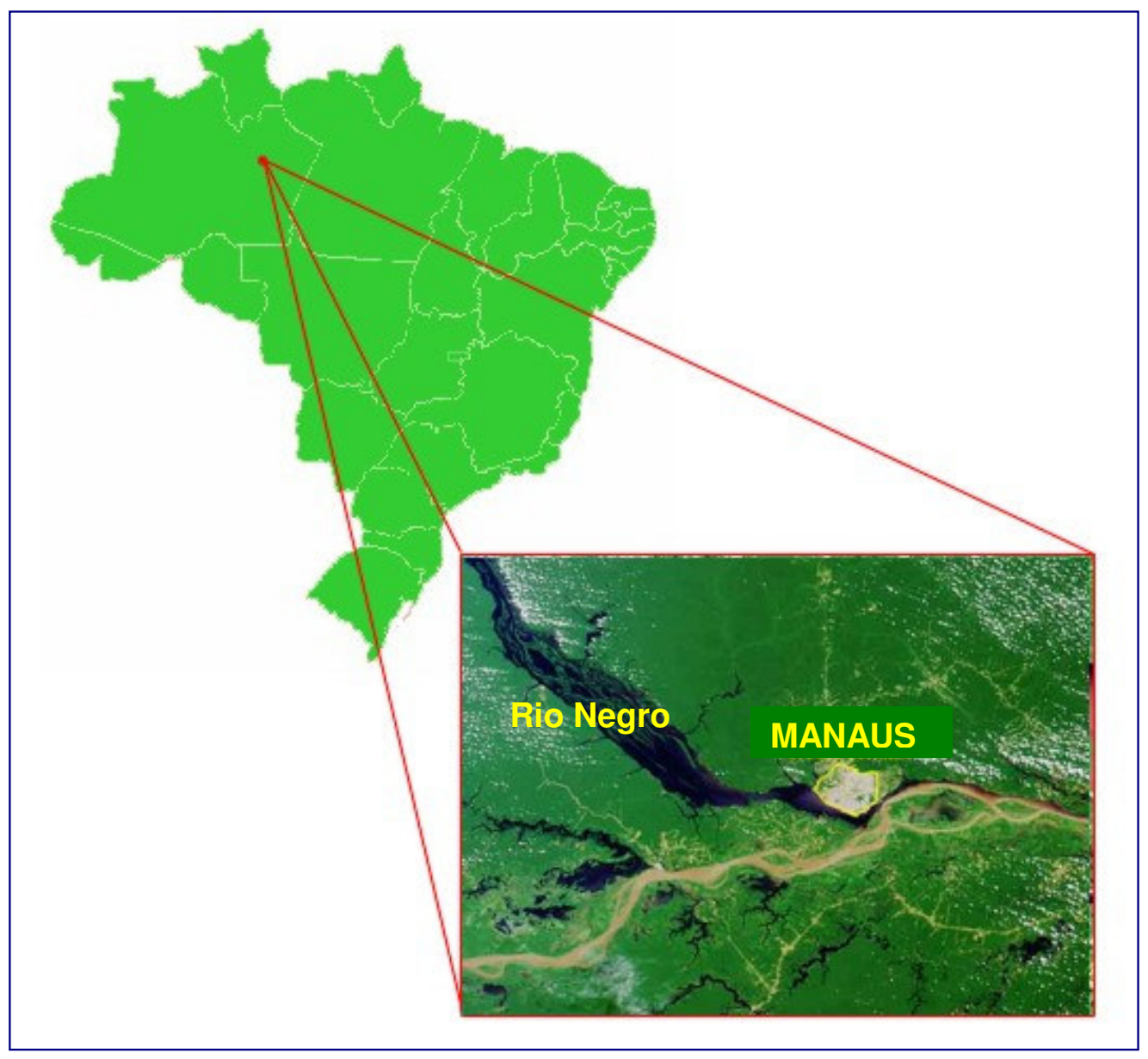

Figura 7. Cidade de Manaus, visão do Satélite MISR, (23/07/2000).

Dados oficiais apontam que a população atinge 1.644 .690 habitantes, segundo censo realizado pelo Instituto Brasileiro de Geografia e Estatística (IBGE) em 2005 (IBGE, 2005). A altitude é variável, ficando entre $25 \mathrm{~m}$ acima do nível do mar (zona portuária) e cotas superiores a $100 \mathrm{~m}$ (áreas próximas ao aeroporto Eduardo Gomes). O clima é equatorial úmido, com temperatura média/dia/anual de $26,7^{\circ} \mathrm{C}$ com variações médias/dia de $23,3^{\circ} \mathrm{C}$ e $31,4^{\circ} \mathrm{C}$. A umidade - relativa do ar fica em torno de $80 \%$ e a média/dia de precipitação anual, de $2.286 \mathrm{~mm}$. A região possui apenas duas estações:

- Chuvosa (inverno) - dezembro a maio: período em que a temperatura é mais amena. Chove quase diariamente. 
- Seca ou menos chuvosa (verão) - junho a novembro: período de sol intenso e temperatura elevada, em torno de $38^{\circ} \mathrm{C}$, chegando a atingir, no mês de setembro, em torno de $40^{\circ} \mathrm{C}$. Costumam ocorrer fortes pancadas de chuva de pouca duração.

A culinária manauara é caracterizada pela utilização de uma grande variedade de peixes provenientes da própria bacia do rio Amazonas. Entre os destaques, podemos encontrar o "pirarucu de casaca" feito com o peixe pirarucu e banana pacovã, o "tambaqui grelhado" outra espécie de peixe encontrada na região, e a tapioca, tipo de "crepe" feito com "goma de mandioca". Ingredientes como coentro, óleo de dendê, além da farinha de mandioca, também denominada de farinha d'água ou amarela, são freqüentemente utilizados. Uma grande variedade de frutas da região também é bastante apreciada na cidade, como a graviola, o cupuaçú, o açaí, o genipapo, o bacuri, a pupunha ${ }^{5}$ e o tucumã (palmeira).

Sua produção agropecuária é baseada no cultivo de mandioca, cupuaçu, cítricos e hortaliças. A pecuária é representada principalmente por bovinos e suínos, com produção de carne e de leite destinada ao consumo local. A pesca é abundante, com exportação para os demais estados do país e exterior. Criada como área de livre comércio, a Zona Franca de Manaus se tornou um pólo de intensa atividade comercial e industrial. Aqui se concentram as principais indústrias de aparelhos eletroeletrônicos, que abastecem o mercado interno. O comércio oferece produtos importados de alta tecnologia a preços acessíveis. Manaus vem se transformando no maior entreposto aduaneiro da América Latina e, em porta de saída de produtos de exportação para os mercados do Caribe e Estados Unidos (Prefeitura de Manaus, 2006).

Um dos maiores atrativos de Manaus, contudo, é a sua localização geográfica: uma grande cidade construída em plena Floresta Amazônica. Ainda é possível ter acesso a áreas bem preservadas desse bioma a poucos quilômetros da cidade. Diferentes ambientes encontrados na Amazônia podem ser facilmente visitados. Entre eles áreas de floresta de terra firme (florestas não alagáveis), várzea (floresta alagável por água branca) e florestas de igapó (florestas alagáveis por água preta). O crescimento da cidade, no entanto, não veio sem o aparecimento ou agravamento de alguns problemas. Manaus vem perdendo cada vez mais sua área verde e, com isso, uma importante amostra da grande biodiversidade encontrada na Amazônia. Entre as principais ameaças encontra-se

\footnotetext{
${ }^{5}$ Pupunha ou pupunheira, conhecida cientificamente por Bactris Gasipaes Kunth, é uma palmeira perene, originária da região tropical das Américas. Tradicionalmente, é usada para produção de frutos, nutritivos e de sabor agradável, consumidos depois de cozidos em água e sal.
} 
a perda ou diminuição dos poucos fragmentos de floresta nativa na área urbana. Isso se torna uma questão ainda mais relevante levando em conta a existência na área de uma das espécies mais ameaçadas de primatas no Brasil, o sauim-de-coleira (Saguinus bicolor), espécie que vive unicamente na área urbana de Manaus.

A cidade encontra-se em um nível turístico muito grande pela sua riqueza natural que atrai milhares de turistas, naturalistas, pesquisadores e jornalistas em busca de um conhecimento aprimorado da região e de sua colonização. Manaus também enfrenta problemas que são característicos de grandes metrópoles onde o poder público não consegue conter a migração e o inchaço do perímetro urbano. A "Zona Franca" se tornou o "Pólo Industrial de Manaus" não com o mesmo poder econômico.

De forma semelhante à praticamente todas as grandes cidades brasileiras, Manaus caracteriza-se por uma expressiva diferenciação sócio-econômica entre seus moradores. A capital amazonense é habitada, majoritariamente, por famílias chefiadas por assalariados de baixa remuneração, trabalhadores da economia informal ou desempregados, em grandes migrantes ou seus filhos, morando geralmente às margens dos igarapés ou de outras áreas centrais deterioradas, em bairros distantes e mal-equipados ou, ainda, em áreas de especulação imobiliárias ou públicas, que passam a ocupar para construir suas casas e que recebem, genericamente, a denominação de “invasões”. Nas áreas da cidade mais equipadas e assistidas pelos serviços públicos residem as famílias situadas no outro lado do espectro social, composto por grandes e médios empresários, funcionários públicos bem situados, empregados de alto nível das empresas do Distrito Industrial, além de setores melhor remunerados da classe média (Nascimento, 2005). Praticamente não existe barreira alguma (nem mesmo ruas) que dividem esses espaços desiguais.

Conforme dados levantados no Atlas Municipal, elaborado pela Prefeitura Municipal de Manaus, através da Secretaria Municipal de Planejamento e Administração, a cidade de Manaus apresenta realidades em desenvolvimento humano só encontradas em países de terceiro mundo convivendo, lado a lado, com outras que, muitas vezes, ultrapassam os parâmetros dos países mais desenvolvidos. Sendo regiões desiguais em renda, são mais ainda em indicadores sociais e principalmente na educação (Atlas Municipal, 2005).

Contudo, de uma forma geral, os indicadores sociais do município são mais satisfatórios que para o restante do Amazonas ou para o conjunto da Região Norte, estando próximo ao das demais capitais estaduais da região, mas ainda longe do que se poderia considerar satisfatório para um município tão economicamente privilegiado. 


\section{Os bairros de Manaus}

No presente estudo, optou-se pela distribuição espacial adotada administrativamente pela Prefeitura Municipal de Manaus com o objetivo de facilitar a avaliação com relação à exposição ao Hg das seis áreas (zonas) administrativas da cidade:

- Zona Centro-Oeste - com um pouco mais de 140 mil habitantes, essa área caracterizou-se pela ocupação através de conjuntos habitacionais. Por isso, seus habitantes são menos afetados por problemas de infra-estrutura, que se resumem a alguns casos isolados. Um dos principais bairros dessa área, o Alvorada, amostrado no presente estudo, originou-se do reassentamento de famílias através do Programa Promorar.

- Zona Centro-Sul - corresponde à área de mais elevado nível sócio-econômico do município, muito embora se note aí também uma certa heterogeneidade. Além de edifícios e condomínios destinados à alta classe média, é também composta de vários conjuntos habitacionais antigos, onde reside uma classe média de menor poder aquisitivo. Área extremamente valorizada comercialmente possui o maior Shopping Center da cidade, agências bancárias, supermercados, rede de televisão, estádio de futebol, comércio e serviços generalizados.

- Zona Leste - com população de cerca de 300 mil habitantes, é a área administrativa mais populosa de Manaus. Caracteriza-se por ocupações de áreas não construídas (invasões) e constitui-se na área mais pobre da cidade, seja em termos de renda monetária, seja em termos de serviços, equipamentos e transportes coletivos. Tem também a maior superfície entre as áreas administrativas e é a que mais se expande espacial e demograficamente.

- Zona Norte - compreende uma vasta área de moradores, a maioria de baixa classe média, muito embora não haja homogeneidade em termos sócio-econômicos. Relativamente bem servida em termos de infra-estrutura urbana, dispõe de ampla variedade de tipologia ocupacional, que engloba os loteamentos, os conjuntos habitacionais e as invasões.

- Zona Oeste - área bastante diferenciada ecológica, urbanística e socialmente, inclui uma parcela de ocupação antiga e próxima ao centro da cidade. Caracteriza-se pela ocupação espontânea processada a partir do bairro de São Raimundo, nos anos quarenta do século passado. 
- Zona Sul - com um pouco mais de 300 mil habitantes, é a área administrativa mais central da cidade. Trata-se de uma área heterogênea em termos de renda, especialmente nas áreas ocupadas situadas às margens dos igarapés que aí existem. Engloba o centro da cidade e sua circunvizinhança, onde se concentram as principais atividades comerciais e de serviços da cidade. Uma parte do próprio Distrito Industrial constitui uma extensão dessa área, já que é invadido pelo Igarapé do Quarenta, o mais importante da cidade.

\section{O rio Negro}

A bacia do rio Negro tem um importante papel no cenário amazônico, por drenar o setor norte-ocidental da região, tendo projeções em territórios colombiano, venezuelano e guianense, embora boa parte das suas águas esteja em território nacional. O complexo de UCs que abrange as áreas do estado do Amazonas e de Roraima pode ser considerado como "Sistema rio Negro". Essas UCs, federais e estaduais, têm como objetivo proteger e/ou manejar uma variedade de ecossistemas peculiares a essa região, como as matas de igapó, campinas, campinaranas e a diversidade etnocultural presente nesses ambientes (FVA, 1998). No Sistema rio Negro existem 43 UCs, de Uso Sustentável e de Proteção Integral, que, juntas contabilizam um total de 29.209.059 ha, protegendo 16,28\% da soma das áreas do estado do Amazonas e de Roraima. O PNJ ocupa uma área equivalente a $1,42 \%$ da superfície total do estado do Amazonas.

A bacia do rio Negro apresenta predominantemente águas pretas provenientes da drenagem de solos amazônicos, com baixa concentração de material particulado e matéria orgânica muito estável. A baixa concentração relativa de material particulado nas águas pretas contribui para que seja observada uma baixa relação entre compostos fúlvicos e húmicos dissolvidos, uma vez que as substâncias húmicas apresentam maior tendência em ser adsorvida em argilas e material particulado do que as fúlvicas. As substâncias húmicas apresentam um importante papel na química da água, pois elas são capazes de complexar metais como o $\mathrm{Hg}$, o qual é consideravelmente menos tóxico quando complexado do que na sua forma livre (Hart, 1981).

Um fato marcante na região do rio Negro, apesar do seu funcionamento intermitente é a exploração mineral feita a partir da iniciativa garimpeira. Concentrada normalmente no alto do curso do rio Negro, essa atividade viveu seu último boom no princípio dos anos de 1990, mobilizando um grande contingente humano. Baseada num modelo de produção considerado 
precário, a exploração mineral deixou um importante saldo de degradação ambiental e social para a região (FVA, 1998).

Forsberg e col. (1994) apud Fadini (1999), verificaram que as concentrações de Hg em peixes do rio Negro e seus tributários, eram bem maiores que as encontradas em peixes de outras regiões da Amazônia sem contaminação antrópica. Foram encontrados peixes com até 2,63 mg kg-1 (limite estabelecido para alimentos no Brasil é de $0,5 \mathrm{mg} \mathrm{kg}^{-1}$ ) no rio Negro, enquanto que o valor máximo encontrado em áreas isentas de garimpo em outras regiões era de $0,71 \mathrm{mg} \mathrm{kg}^{-1}$. Estes valores de $\mathrm{Hg}$ encontrados em peixes são próximos dos encontrados em áreas antigas de garimpo com problemas crônicos de contaminação de $\mathrm{Hg}$. Acredita-se que estes níveis altos sejam uma conseqüência natural das características biogeoquímicas das águas e morfológicas do rio Negro.

Como são poucas ou passadas as fontes antrópicas registradas na bacia do rio Negro, o mecanismo mais provável para esta contaminação é a partir do solo. Os solos que predominam na bacia Amazônica são extremamente antigos e apresentam uma elevada capacidade de reter $\mathrm{Hg}$ e acumulá-lo durantes muitos anos (Miretzky e col., 2005). Vários estudos com latossolos argilosos desta região têm revelado a existência de altos teores de $\mathrm{Hg}$ associados com complexos organometálicos na fração mineral do solo (Fadini \& Jardim, 2001). No entanto, ao se comparar a quantidade de $\mathrm{Hg}$ acumulado nestes solos com as estimativas de deposição mercurial associada com fontes antrópicas regionais, Roulet e colaboradores (1997) concluíram que mais de 90\% do $\mathrm{Hg}$ presente no solo era de origem natural.

Segundo Lacerda \& Pfeiffer (1992), o Hg lançado nas águas amazônicas tem seu comportamento estabelecido em função das características físico-químicas do corpo d’água. $\mathrm{O} \mathrm{Hg}$ metálico deposita-se rapidamente nos sedimentos, apresentando mobilidade muito baixa. Na coluna d’água estarão presentes os compostos mercuriais remobilizados de solos, como formas metiladas e complexadas e uma pequena fração proveniente da mobilização e transformação do $\mathrm{Hg}$ metálico depositado nos sedimentos, principalmente nos rios de água preta, a exemplo do rio Negro e do rio Jaú, onde a formação de compostos organo-mercuriais é facilitada. Às fontes citadas, deve-se ainda acrescentar a deposição atmosférica. As características únicas das águas dessa bacia, associadas à intensa radiação solar que as atingem tornam a região rica em processos químicos e fotoquímicos complexos, que influenciam diretamente o ciclo do $\mathrm{Hg}$ e de todos os outros elementos ali presentes (Fadini \& Jardim, 2001).

Frente à existência de indicativos de contaminação por $\mathrm{Hg}$ na bacia do rio Negro, proveniente de uma fonte não localizada, Fadini (1999) realizou um estudo visando à obtenção de 
informações a respeito da concentração do metal em diferentes compartimentos, bem como, evidências do transporte inter-reservatórios deste metal nesta região. As águas coletadas na bacia do rio Negro, analisadas nesse estudo realizado por Fadini (1999) mostraram um pH mediano de 4,86, apresentando valores de até 3,78, medidos imediatamente após a estação chuvosa. As águas pretas apresentaram ainda poucos sólidos dissolvidos e valores de condutividade por volta de $15 \mu \mathrm{S} \mathrm{cm}^{-1}$. A avaliação de corpos aquáticos de 16 afluentes do rio Negro foram feitas para determinações de carbono orgânico total e Hg total, em coletas realizadas entre Manaus e Santa Izabel do rio Negro, sendo que o rio Jaú, um dos afluentes analisados, apresentou o valor de 11,6 $\mathrm{mg} \mathrm{L}^{-1}$ para carbono orgânico (COT) e 3,3 \pm 0,3 ng L ${ }^{-1}$, para $\mathrm{Hg}$ total. Quanto aos valores obtidos, as concentrações de $\mathrm{Hg}$ total encontradas no rio Negro e em seus afluentes, apresentaram a mesma ordem de grandeza dos afluentes do Lago Michigan, em Hurley e col., 1998 apud Fadini (1999). Levando-se em consideração o nível de atividades antrópicas nestas duas regiões, concluiu-se que as concentrações encontradas em águas de rios nesse trabalho foram elevadas. A concentração total de $\mathrm{Hg}$ gasoso observada na região de estudo, apresentou um valor esperado para regiões não contaminadas. No entanto, com a recomendação da continuidade da avaliação do compartimento atmosférico do $\mathrm{Hg}$ a partir de valores de deposição do metal, uma vez que a baixa concentração relativa na atmosfera pode ser fruto de mecanismos deposicionais que retiram o $\mathrm{Hg}$ da fase gasosa. A concentração de $\mathrm{Hg}$ total nos solos estudados ao longo da bacia do rio Negro $\left(172 \mathrm{mg} \mathrm{kg}^{-1}\right)$ foi, ainda, considerada alta, frente aos teores observados em outros locais do planeta (Fadini, 1999).

Em outro estudo subseqüente, Bisinoti (2005) avaliou a biogeoquímica do MeHg na bacia do rio Negro com o objetivo de contribuir para o entendimento do ciclo biogeoquímico do Hg na mesma. Com base nos experimentos realizados nesse trabalho tornou-se possível estabelecer parte do modelo que explica o comportamento do MeHg nas águas da bacia do rio Negro. No contexto apresentado para águas pretas, Bisinoti argumenta que durante o período de cheia ocorre um aporte significativo de matéria orgânica lábil nos rios e lagos, que ao serem fotodegradadas com o auxílio do peróxido de hidrogênio (reação de Fenton) ${ }^{6}$ geram espécies transientes como radicais hidroxilas capazes de oxidar o $\mathrm{MeHg}$ mantendo as águas ricas $\mathrm{em}^{2{ }^{2+}}$. Por sua vez, no período de vazante, à medida que a matéria orgânica vai se tornando recalcitrante na coluna d’água e, portanto, esgotando sua capacidade fotodegradativa a diminuição da concentração das espécies transientes permitiria a saturação destas águas com $\mathrm{Hg}^{2+}$. Uma outra rota seria através da degradação do MeHg que seria

\footnotetext{
${ }^{6}$ A reação de Fenton é baseada na decomposição catalítica de peróxido de hidrogênio em meio ácido e constitui um processo de grande potencialidade para o tratamento de efluentes. Esta reação tem sido estudada na oxidação de fenóis, clorofenóis, nitrobenzeno entre outros compostos (Tang \& Chen, 1996).
} 
transformado em $\mathrm{Hg}^{2+}$ pela radiação solar, bem como, pelas espécies transientes que mesmo em menor concentração estariam disponíveis para interagir com o ciclo do $\mathrm{Hg}$, uma vez que a matéria orgânica seria quase que predominantemente recalcitrante. Concluiu-se também, que a quantidade de $\mathrm{MeHg}$ presente nas águas da bacia do rio Negro é dependente do balanço entre sua degradação pela radiação solar e espécies transientes produzidas na água e sua produção pela matéria orgânica lábil ou microorganismos. 


\section{CAPÍTULO 3}

\subsection{Avaliação Dietética}

Existem cerca de 40 nutrientes presentes nos alimentos que são absorvidos no aparelho digestivo e degradados para, de novo, formarem outras substâncias essenciais para o organismo, sendo classificados basicamente de duas formas:

1) de acordo com sua função - energética, reguladora ou plástica;

2) agrupados como nutrientes fornecedores ou não de energia.

Neste último caso têm-se os nutrientes fornecedores de calorias, também chamados de macronutrientes e são aqueles que formam o corpo da dieta e, além de fornecerem energia, fornecem as substâncias essenciais para o funcionamento do metabolismo. Os principais macronutrientes são: carboidratos (glicose), gorduras e óleos (estão incluídos os ácidos graxos), proteínas (aminoácidos), macrominerais e água (Corsino, 2000).

Aqueles que não fornecem calorias, os micronutrientes, ou seja, elementos inorgânicos (minerais) e vitaminas, também desempenham papel fundamental na saúde e são classicamente considerados como compostos essenciais para a vida humana, compreendendo 13 vitaminas e aproximadamente 16 minerais. Tais vitaminas e minerais não são sintetizados pelo organismo humano (ou em alguns casos em quantidades insuficientes), por isso devem ser obtidos através da alimentação (Corsino, 2000). Estes elementos estão relacionados à saúde humana e às doenças, uma vez que seu excesso ou deficiência pode induzir mudanças fisiológicas no organismo (Abdulla e col., 1989).

\section{As necessidades nutricionais}

A ingestão de nutrientes não pode ser aleatória. O nosso organismo necessita de uma quantidade diária específica para o seu bom funcionamento e, para tanto, foram estabelecidos limites superiores e inferiores de ingestão, bem como um limite superior tolerável, muito observado hoje em dia devido ao grande interesse em alimentos fortificados e o aumento do uso de suplementos alimentares. Estes valores auxiliam em estudos nutricionais e na busca de uma dieta 
saudável, garantindo que a ingestão de nutrientes não seja muito baixa causando deficiência e nem muito alta, causando toxicidade.

Pesquisadores de vários países procuram montar um banco de dados para composição de nutrientes, objetivando determinar se a sua ingestão está adequada, excessiva ou para elaborar um plano de dieta que esteja nutricionalmente adequada. A ORGANIZAÇÃO MUNDIAL DA SAÚDE (WHO, 1994), através da Comissão do Codex Alimentarius da FAO/WHO vem ajudando neste objetivo, estabelecendo, além das necessidades nutricionais para alguns nutrientes (proteínas, vitaminas, $\mathrm{Ca}, \mathrm{Cu}, \mathrm{Fe}, \mathrm{Se}$ e $\mathrm{Zn}$ ), também os valores de ingestão semanal tolerável provisória (PTWI) ou os valores de ingestão diária aceitável (ADI) para os elementos tóxicos ou potencialmente tóxicos, como alumínio, $\mathrm{As}, \mathrm{Cd}, \mathrm{Hg}, \mathrm{Sn}$ e Pb. Há também as DRIs (Dietary Reference Intakes ou "Ingestão Alimentar de Referência"), que são recomendações de ingestão de nutrientes para os Estados Unidos e Canadá, estabelecidas pelo Food and Nutrition Board of the Medicine Institute. As DRIs são baseadas na compilação de pesquisas que estudam a necessidade diária dos nutrientes e, portanto, podem ser utilizadas por profissionais da área da saúde de outros países até que estes consigam dados suficientes da população nacional. Incluem quatro conceitos de referência para consumo de nutrientes, estabelecidos e usados para o planejamento e avaliação das dietas do indivíduo ou grupos de indivíduos saudáveis, com definições e aplicações diferenciadas: Estimated Average Requirement ou "Estimativa do Requerimento Médio" (EAR), Recommended Dietary Allowance ou "Recomendações de Doses ou Cotas Alimentares" (RDA), Adequate Intake ou "Ingestão Adequada" (AI), Tolerable Upper Intake Level ou "Limite de Ingestão Máxima Tolerável” (UL) (Marchioni e col., 2004; Otten e col., 2006).

Desse modo, no estudo da composição dos alimentos largamente consumidos pela população é fundamental estabelecer se uma determinada dieta é adequada em relação aos nutrientes essenciais e também verificar se a ingestão dos contaminantes não excede os níveis máximos de tolerância, estabelecidos pelos organismos internacionais de saúde.

O estado nutricional reflete o grau nos quais as necessidades fisiológicas quanto à ingestão dos nutrientes estão sendo atendidas, ou seja, a relação entre o consumo de alimentos e as necessidades nutricionais do indivíduo. Envolve o estudo de diversos fatores que regularizam o metabolismo dos nutrientes, os quais incluem níveis de ingestão e biodisponibilidade, transporte, estocagem e excreção dos mesmos (Christakis, 1973). A avaliação da ingestão de nutrientes é parte da avaliação nutricional, sendo utilizada para a tomada de decisão quanto à adequação do consumo 
alimentar do indivíduo e auxiliar no estabelecimento da conduta dietoterápica, em conjunto com outros parâmetros (Marchioni e col., 2004).

A complexidade da dieta humana tem instigado pesquisadores a procurar os meios mais adequados para avaliar qualitativa e quantitativamente o consumo de alimentos, dimensionar a adequação de nutrientes e relacionar dieta e o desenvolvimento de doenças (Cavalcante e col., 2004). Entretanto, a detecção de associações entre a ingestão alimentar e o risco de doenças, em estudos populacionais, é limitada pela dificuldade de se mensurar o consumo de forma acurada. Este problema é inerente a todos os métodos de avaliação da ingestão alimentar que dependem do relato individual.

Fatores como complexidade da dieta, hábitos alimentares, qualidade da informação, idade, imagem corporal, memória, crenças, comportamento, cultura e status socioeconômico, bem como fatores de exposição, são variáveis que interferem e tornam muito difícil o ato de registrar a ingestão de um indivíduo, sem exercer influência sobre esse (Fisberg e col., 2000). As tabelas de composição alimentar também não são completas, nem exatas para os alimentos consumidos atualmente. $\mathrm{O}$ modo de preparo dos alimentos varia muito e pode também influenciar bastante os valores nutritivos (Maihara, 1996).

Várias metodologias vêm sendo utilizadas para avaliar o consumo dietético de indivíduos em estudos epidemiológicos, no sentido de obter dados válidos, reprodutíveis e comparáveis. Dentre estes métodos se destacam o questionário de freqüência alimentar, o recordatório de 24 horas, o método do inventário, o registro diário ou diário alimentar, e a história dietética (Cavalcante e col., 2004). Mas, devido ao uso e as limitações de cada método, a escolha do instrumento para medir a informação dietética não constitui tarefa fácil (Bonomo, 2000). Entretanto, cada método tem suas vantagens e desvantagens, pois quando se fala na avaliação de macro e microelementos minerais, a avaliação dietética por meio de inquéritos e tabelas de composição de alimentos torna-se pouco satisfatória. A informação obtida por estes métodos não proporciona dados reais sobre o consumo de nutrientes sendo, portanto, recomendada a análise química laboratorial da porção em duplicata, onde a dieta é composta a partir da duplicata de todos os alimentos e bebidas consumidos durante o período de estudo (WHO, 1972).

Neste capítulo, no item 3.2. serão feitas algumas considerações metodológicas sobre estudos que visam avaliar a ingestão de nutrientes, assim como, apresentar um resumo dos vários métodos que têm sido utilizados na avaliação do consumo de alimentos, inclusive o método da porção em duplicata, utilizado no presente estudo. 
No capítulo 7, serão apresentados e discutidos os valores de ingestão diária para cada elemento analisado no presente estudo ( $\mathrm{Ca}, \mathrm{Fe}, \mathrm{K}, \mathrm{Na}, \mathrm{Se}, \mathrm{Zn}$ e $\mathrm{Hg}$ ). Estes valores serão comparados aos valores tabelados de EAR (utilizado na avaliação de grupos) para crianças em idade pré-escolar (4 - 8 anos), aos valores de AI para adultos, para os micronutrientes os quais não ainda não possuem valores EAR e o PTWI (Provisional Tolerable Weekly Intake) o elementos tóxico Hg. Neste mesmo capítulo, item 7.3, serão apresentados e discutidos os resultados e adequação das dietas das crianças do PNJ e comunidades da região Amazônica analisadas em relação a proteínas, lipídeos e carboidratos.

No Brasil, poucos grupos de pesquisa estão direcionados para avaliação do estado nutricional de grupos populacionais através da análise química direta de dietas. O grupo de pesquisadores do LAN/CRPq (IPEN) utilizou o método da porção em duplicata para avaliar a ingestão de inúmeros elementos essenciais e tóxicos, bem como a composição centesimal, a partir de dietas consumidas por crianças (Maihara e col., 1995, 1998), idosos (Cordeiro, 1994), estudantes universitários (Favaro e col., 1997; 2000a), utilizando-se a técnica de Análise por Ativação Neutrônica (AAN). Vários métodos são utilizados na análise de alimentos, apresentando bons resultados, como por exemplo, a espectrometria de absorção atômica e a espectrometria de massa com plasma induzido. Contudo, a AAN tem sido muito utilizada para a análise dessas matrizes, uma vez que este método é um dos mais importantes dentre os disponíveis para a determinação qualitativa e quantitativa de elementos traço, por ser um método sensível, não destrutivo e multielementar. Esta técnica baseia-se na irradiação do material em estudo com nêutrons dando origem a isótopos radioativos dos elementos presentes. Estes radionuclídeos são identificados e quantificados pela energia, taxa de desintegração e intensidade da radiação gama associada ao seu decaimento radioativo (IAEA, 1990).

Com relação à determinação do $\mathrm{Hg}$, também discutido neste trabalho, várias outras técnicas analíticas vêm sendo empregadas com sucesso, mas provavelmente a mais utilizada é a espectrometria de absorção atômica com geração de vapor frio (CV AAS), que propicia limites de detecção muito baixos para a determinação do Hg (Haswell, 1991). 


\title{
3.2. O estudo da dieta: considerações metodológicas
}

\begin{abstract}
"A Nutrição ou Ciências Nutricionais, como gosto de chamá-la, é uma área interprofissional e multidisciplinar, biológica e social tanto nos seus fundamentos quanto em suas aplicações. Estuda todos os mecanismos por meio dos quais os organismos vivos recebem e utilizam as substâncias necessárias ao funcionamento orgânico normal."'7
\end{abstract}

Os agravos relacionados à nutrição dos indivíduos constituem prioridade para a saúde pública em países desenvolvidos e em desenvolvimento, tanto nas regiões metropolitanas quanto nos municípios de pequeno porte. Como citado anteriormente, os estudos epidemiológicos têm fornecido evidências sobre a importância da dieta como fator de risco para inúmeras doenças e vários alimentos e nutrientes têm sido relacionados tanto à ocorrência quanto à prevenção de doenças crônicas, em diferentes populações.

Com base em estatísticas divulgadas amplamente por organismos internacionais, acredita-se existir no mundo subdesenvolvido cerca de 404 milhões de crianças em idade inferior a cinco anos, desnutridas. Dentre estas, 174 milhões de crianças apresentam baixo peso para a idade e 230 milhões apresentam baixa estatura para a idade (Carvalho e col., 2003).

A criança deve consumir a quantidade de alimento necessária para alcançar seu potencial genético de crescimento. O tamanho corporal a ser alcançado na vida adulta não é de primordial importância, entretanto, o atraso no crescimento, devido às circunstâncias nutricionais e ambientais, está associado com maiores taxas de morbidade e mortalidade, com deficiências no aprendizado e com menor capacidade física e intelectual na vida adulta (Philippi e col., 1999a). As fases da vida pré-escolar e escolar e da adolescência são excelentes momentos para uma orientação nutricional ativa e participativa, portanto, a alimentação deve ser saudável e adequada a cada uma destas fases, respeitando-se as características individuais.

Informações válidas sobre o consumo de alimentos, energia e nutrientes são, portanto, de vital importância em diversas áreas das ciências da saúde e tais dados poderão ser utilizados como base para recomendações nutricionais, políticas de saúde pública e pesquisas epidemiológicas sobre as relações entre alimentação e saúde.

\footnotetext{
${ }^{7}$ Trecho do prefácio elaborado pelo Prof ${ }^{o}$. Dr. J.E. Dutra de Oliveira da Faculdade de Medicina de Ribeirão Preto no livro Biodisponibilidade de Nutrientes (Cozzolino, 2005). 


\section{Avaliação do consumo de alimentos e da ingestão dietética}

Os vários métodos para conhecimento e avaliação do hábito alimentar diferem entre si quanto à maneira como a informação é coletada, o tempo necessário para a coleta dos dados e o tipo de informação que se procura.

De forma genérica, é possível subdividir os métodos de investigação do consumo alimentar em dois grupos:

a) àqueles utilizados na prática clínica, com interesses individuais e específicos relacionados à quantidade e qualidade da alimentação, podendo inclusive despender, na maioria dos casos, mais tempo e dinheiro para a sua aplicação.

b) àqueles utilizados em estudos epidemiológicos, que valorizam mais a questão populacional, deixando de lado as particularidades do indivíduo. Neste caso a praticidade na aplicação do método e o custo são mais valorizados.

A avaliação do consumo alimentar tem um papel crítico na área de pesquisa de nutrição, os estudos científicos, portanto, devem ser conduzidos com objetivos definidos, os quais podem descrever a distribuição e a magnitude dos agravos à saúde em populações humanas, elucidar a etiologia das doenças, gerar as informações necessárias para o planejamento e implementação de serviços e programas para prevenção, controle e tratamento de doenças. O início da investigação é a clara definição do problema e o estabelecimento das hipóteses. A partir daí, selecionam-se os métodos, considerando-se também os recursos humanos e materiais.

Vários pesquisadores têm se dedicado aos estudos de dietas de diferentes grupos populacionais. Albuquerque \& Monteiro (2002), realizaram estudo avaliando a ingestão de alimentos e adequação de nutrientes no final da infância em 247 escolares, com idade de nove e dez anos, pertencentes a escolas públicas municipais de Maceió. De acordo com os resultados, a ingestão alimentar dos escolares apresentou-se deficiente em relação à energia e aos micronutrientes. Scagliusi \& Lancha Júnior (2003), discutiram a subnotificação da ingestão energética na avaliação do consumo alimentar. Amancio \& Chaud (2004), avaliaram diversas dietas para redução de peso, anunciadas em periódicos não científicos. Duas publicações foram selecionadas em função da periodicidade, tiragem, número de leitores e anos de publicação. Foi utilizado o programa Virtual Nutri para medir os nutrientes de 112 dietas e os teores de micronutrientes foram comparados com as DRIs. Todas as dietas eram inadequadas em relação a uma ou mais substâncias avaliadas. Lopes e col. (2005) avaliaram o consumo de nutrientes em 
adultos e idosos em estudo de base populacional: Projeto Bambuí, Minas Gerais, utilizando o Questionário Semiquantitativo de Freqüência Alimentar e Recordatório de 24 horas calibrados pela técnica de regressão linear.

Pesquisas de consumo de alimentos constituem instrumentos eficazes e de baixo custo para obtenção de informações de grande parte da população; entretanto, um dos maiores problemas quando se quer estudar a ingestão dos elementos traço essenciais e tóxicos de uma determinada população é a obtenção de dados confiáveis do consumo real de alimentos, principalmente em países como o Brasil, onde não existem informações atualizadas sobre inquérito alimentar ou de cestas básicas de alimentos, que representem o consumo das diferentes camadas sociais ou de diferentes regiões do país, que têm hábitos regionais próprios de consumo (Favaro e col., 2000b). A detecção de associações entre a ingestão alimentar e o risco de doenças em estudos populacionais é limitada pela dificuldade de se mensurar o consumo de forma acurada. Este problema é inerente a todos os métodos de avaliação de ingestão alimentar que dependem do relato individual.

Para tanto, a escolha do método deve fundamentar-se nos objetivos da pesquisa ou no tipo de estudo, além de considerar os recursos disponíveis. Fundamental também é a escolha dos instrumentos de avaliação do consumo, que devem conferir validade e reprodutibilidade, além de caracterizar fielmente a dieta do indivíduo (Willet, 1998).

Segundo considerações de alguns autores, a escolha do método demonstra o desafio que se impõe aos pesquisadores na avaliação correta do consumo alimentar em estudos epidemiológicos (Bonomo, 2000; Fisberg e col., 2000).

As abordagens utilizadas para avaliar o consumo de alimentos comumente encontram-se conjugadas entre si ou associadas a outros parâmetros de avaliação do estado nutricional de indivíduos. Essa junção pode propiciar melhor compreensão e interpretação dos resultados obtidos em determinado estudo (Fontanive e col., 2002).

Em geral, há quatro utilizações predominantes para os dados de ingestão dietética: avaliação e monitoramento da ingestão de alimentos e nutrientes de um determinado grupo ou população, formulação e avaliação de políticas públicas nas áreas da saúde e agricultura, condução de estudos epidemiológicos e para propósitos comerciais. A avaliação da dieta inclui a consideração dos tipos e quantidades de alimentos consumidos e a ingestão de nutrientes e de outros compostos, que sejam naturais, formados durante a cocção ou nos processos de preservação dos alimentos (Marchioni e col., 2003). 


\section{Métodos de avaliação de ingestão dietética}

\section{- Questionário de freqüência de consumo alimentar (QFCA):}

Consiste em dois componentes principais: uma lista de alimentos e uma lista de freqüência de consumo. Os indivíduos relatam a freqüência de consumo de cada item alimentar, em categorias previamente estabelecidas. Esse método tem sido citado por muitos autores como um dos principais instrumentos metodológicos para estudos epidemiológicos que relacionam a dieta à ocorrência de doença, por avaliar a ingestão alimentar de populações, ter boa reprodutibilidade e validade aceitável, além de ser mais prático, informativo, de fácil aplicação e de baixo custo (Villar, 2001).

A construção de questionários pode ser feita a partir de um banco de dados de alimentos e preparações mais freqüentemente consumidos pela população a ser estudada, ou a partir de tabelas de composição de alimentos.

O QFCA é relativamente fácil de ser preenchido, podendo inclusive ser auto-administrado. O processamento dos dados pode ser feito eletronicamente, de maneira rápida. Estas características o tornam viável para utilização em estudos que envolvem um grande número de pessoas, como nos estudos de coorte para investigação de doenças crônicas não transmissíveis.

\section{- Tabelas de composição de alimentos:}

Para estimar a ingestão total de energia e nutrientes, de cada indivíduo em um estudo, é necessário obter informações sobre o conteúdo de cada item alimentar que foi relatado, qualquer que tenha sido o método utilizado para a obtenção desse dado. Como discutido anteriormente, todos os métodos estão sujeitos a erros. Entretanto, os erros na avaliação do consumo alimentar também estão relacionados à conversão dos dados em quantidades de nutrientes, pelas tabelas e softwares de composição de alimentos (Ribeiro e col., 2003).

As tabelas brasileiras freqüentemente estão desatualizadas e incompletas em termos de alimentos e nutrientes, sendo pouco confiáveis por falta da descrição de procedimentos analíticos ou pelo emprego de técnicas analíticas inadequadas. Paralelamente, muitos dados são provenientes de tabelas estrangeiras que nem sempre refletem a realidade dos alimentos nacionais (Lajolo \& Menezes, 2004). A FAO e a UNU (Universidade das Nações Unidas) preconizam que a cooperação internacional é a melhor forma para a obtenção de dados confiáveis de composição de alimentos, a 
custo reduzido. Assim foram criadas redes regionais (INFOODS/LATINFOODS/BRASILFOODS) com o objetivo de elaborar, difundir e coordenar atividades para melhorar a qualidade e disponibilidade de dados sobre composição de alimentos. Neste sentido, o Projeto Integrado de Composição de Alimentos elaborou um Banco de Dados Brasileiro de Composição de Alimentos, adotando critérios de acordo com as diretrizes propostas pelo INFOODS, visando a integração e validação das informações brasileiras no contexto nacional e mundial.

\section{- Recordatório de 24 horas (R24h):}

Consiste em obter informações escritas ou verbais sobre a ingestão alimentar das últimas 24 horas, com dados sobre os alimentos atualmente consumidos e informações sobre peso/tamanho das porções que deveriam ser, em tese, fornecidas por meio de fotografias ou modelos de porções. Muito utilizado em todo o mundo, este método é um instrumento de avaliação da ingestão de alimentos e nutrientes de indivíduos e grupos populacionais, mas requer um nutricionista ou entrevistador bem treinado para a realização da coleta de dados. Em geral, esse instrumento é bem aceito pelos entrevistados, o tempo de aplicação é curto, o custo é baixo e não promove alteração da dieta habitual (Salvo \& Gimeno, 2003).

Como desvantagens do $\mathrm{R} 24 \mathrm{~h}$ temos que o relato de apenas um dia não reflete o hábito alimentar do indivíduo, não sendo adequado para o estudo da relação entre hábito alimentar e o aparecimento de determinadas doenças. Dados oriundos de um recordatório apenas, não devem ser utilizados para estimar a proporção da população que tem ou não dietas adequadas.

\section{- Pesagem de alimentos:}

Esse método consiste no registro, pelo entrevistador, das quantidades de alimentos que efetivamente irão ser consumidas pelo entrevistado em medidas caseiras ou mediante pesagem direta dos alimentos, com auxílio de uma balança doméstica (Bonomo, 2000).

Cruz (2001) em estudo de consumo alimentar de crianças entre um e seis anos, de três creches da cidade de São Paulo, utilizou o método da pesagem direta para obter o peso médio das porções de alimentos oferecidas às crianças, dados de consumo alimentar e avaliar a concordância de dados de consumo. Com base nos resultados obtidos o autor relata que há concordância na comparação da pesagem direta de alimentos em nível individual e total, embora o individual seja 
mais preciso e sugere que esse método possa ser utilizado com bons resultados para definir, em curto prazo, políticas de nutrição e saúde.

Embora seja considerado o mais exato para determinar a ingestão de alimentos, é um método mais demorado, oneroso, altamente invasivo e exige alto nível de cooperação das famílias e indivíduos (Bonomo, 2000).

\section{- História dietética (HA):}

A história dietética consiste em extensa entrevista, realizada por um nutricionista, para obtenção de um padrão alimentar global.

O método da HA foi originalmente criado por Burke, em 1930, com o objetivo de estabelecer a ingestão habitual durante vários meses ou anos, baseando-se em informações coletadas do próprio entrevistado ou de seus pais. Esse método, após sofrer muitas variações em sua aplicação, inclui, hoje, três elementos: 1) entrevista detalhada sobre o padrão de alimentação; 2) uma lista de alimentos cuja freqüência e periodicidade do consumo alimentar é anotada e 3) um registro alimentar de três dias (Salvo \& Gimeno, 2003).

\section{- Estudo da porção em duplicata:}

No método de porção em duplicata, coletam-se as refeições efetuadas de um grupo de pessoas selecionadas, incluindo bebidas e lanches, durante certo período, que pode variar de um a sete dias e as quais são misturadas de modo a formar uma dieta completa. É efetuada então a análise química laboratorial da porção em duplicata da dieta consumida (Abdulla, 1979).

As principais vantagens desse estudo incluem:

- as análises são realizadas em uma réplica dos alimentos que são realmente consumidos por um indivíduo;

- dados de consumo de alimentos não são necessários;

- não há necessidade de grandes recursos financeiros.

A principal desvantagem é que os dados obtidos por esse estudo se restringem a uma população pequena. Além disso, uma vez que os alimentos são coletados e misturados em grandes 
recipientes, não é possível analisar os alimentos individuais ou grupos de alimentos (Maihara, 1996). 


\section{CAPÍTULO 4}

\section{Metodologias Analíticas}

Neste trabalho foram utilizados um método específico para a análise do $\mathrm{Hg}$ total e $\mathrm{MeHg}$ com a utilização da Espectrometria de Absorção Atômica com geração de vapor frio (CV AAS) e um método seletivo para a determinação de outros elementos traço, Análise por Ativação Neutrônica (AAN).

\subsection{Espectrometria de absorção atômica com geração de vapor frio e injeção em fluxo (CV AAS) - determinação de mercúrio (Horvat, 1996)}

O interesse em determinar teores de $\mathrm{Hg}$ para estimar o seu real impacto no meio ambiente, principalmente no sistema aquático, na vegetação e nos humanos, levou a um grande progresso no desenvolvimento de técnicas de análise para este metal. Além disso, a alta toxicidade aliada ao baixo nível de $\mathrm{Hg}$ em algumas amostras, bem como, a sua natureza volátil e associação com outros compostos, faz com que sejam necessárias técnicas bastante sensíveis e precisas para a sua determinação em diferentes matrizes. Durante os últimos anos várias técnicas analíticas surgiram e têm contribuído significativamente para o entendimento da química do $\mathrm{Hg}$ em sistemas naturais. Os métodos analíticos são selecionados dependendo da natureza da amostra e, em particular, dos níveis de teores de $\mathrm{Hg}$.

A espectrometria de absorção atômica (AAS - do inglês Atomic Absorption Spectrometry) é uma técnica analítica, proposta em 1955, empregada para a determinação de vários elementos químicos em uma ampla variedade de amostras (águas, materiais biológicos, clínicos, ambientais, geológicos, etc.). A análise fundamenta-se na medida da absorção da intensidade da radiação eletromagnética, proveniente de uma fonte de luz, por átomos gasosos no estado fundamental. 
Existem hoje pelo menos quatro modalidades, as quais são subdivididas de acordo com o tipo de atomizador ${ }^{8}$ : a espectrometria de absorção atômica com atomização por chama, por geração de hidretos, por geração de vapor a frio e atomização eletrotérmica, sendo que esta última pode ser feita com detecção mono ou multielementar. No presente trabalho utilizamos a espectrometria de AAS com geração de vapor frio que vem a ser uma técnica bastante apropriada para a determinação dos teores de $\mathrm{Hg}$ total e $\mathrm{MeHg}$ nas amostras de peixes, cabelos e dietas. Os procedimentos foram baseados no princípio desenvolvido por Poluektov e colaboradores (Hatch \& Ott, 1968; Poluektov \& Zelykova, 1969).

A análise do Hg por absorção atômica dispensa o uso da chama para a atomização do metal, porque no produto final a ser submetido à operação, o Hg inorgânico, é reduzido a seu vapor monoatômico por meio de um agente redutor. Em geral, a determinação do elemento envolve as seguintes etapas: coleta da amostra, pré-tratamento/preservação/estocagem, liberação do Hg da matriz, extração/"clean-up"/pré-concentração, separação das espécies de interesse de Hg, quantificação, sendo que existem dois aspectos importantes que são críticos na análise de $\mathrm{Hg}$ : procedimentos de descontaminação e calibração de padrões.

Para se conseguir uma liberação quantitativa do $\mathrm{Hg}$ da amostra, os procedimentos de oxidação via úmida requerem um ou mais agentes oxidantes com qualidade apropriada (baixo nível de $\mathrm{Hg}$ ). As amostras são normalmente digeridas em sistemas fechados ou semifechados, em temperaturas elevadas (no máximo $90-100^{\circ} \mathrm{C}$ ). Deve-se ter cuidado para prevenir perdas de $\mathrm{Hg}$ em temperaturas de digestão elevadas. $\mathrm{O}$ agente redutor $\left(\mathrm{SnCl}_{2}\right.$ ou $\left.\mathrm{NaBH}_{4}\right)$ é adicionado ao frasco de reação contendo a amostra preparada. $\mathrm{O}$ vapor de $\mathrm{Hg}^{0}$ é então liberado da solução amostra e arrastado diretamente para a célula do espectrômetro ou é pré-concentrado numa superfície de ouro, antes de ser dessorvido por meio de calor antes da análise. Tais processos redução-aeração são fáceis de realizar, rápidos, seletivos e exatos quando comparados com muitas outras técnicas. Para a determinação do $\mathrm{MeHg}$, contudo, há a necessidade de se distinguir o Hg total do MeHg em uma determinada amostra, antes da medida no espectrômetro (CV AAS) (Figura 8). Para tanto, utiliza-se uma lixiviação ácida e posterior separação do Hg orgânico e inorgânico utilizando-se uma coluna de troca iônica.

\footnotetext{
${ }^{8}$ Dispositivo onde são gerados os átomos para que possam absorver a radição proveniente da fonte de radiação e conseqüentemente se determinar a concentração do elemento de interesse.
} 


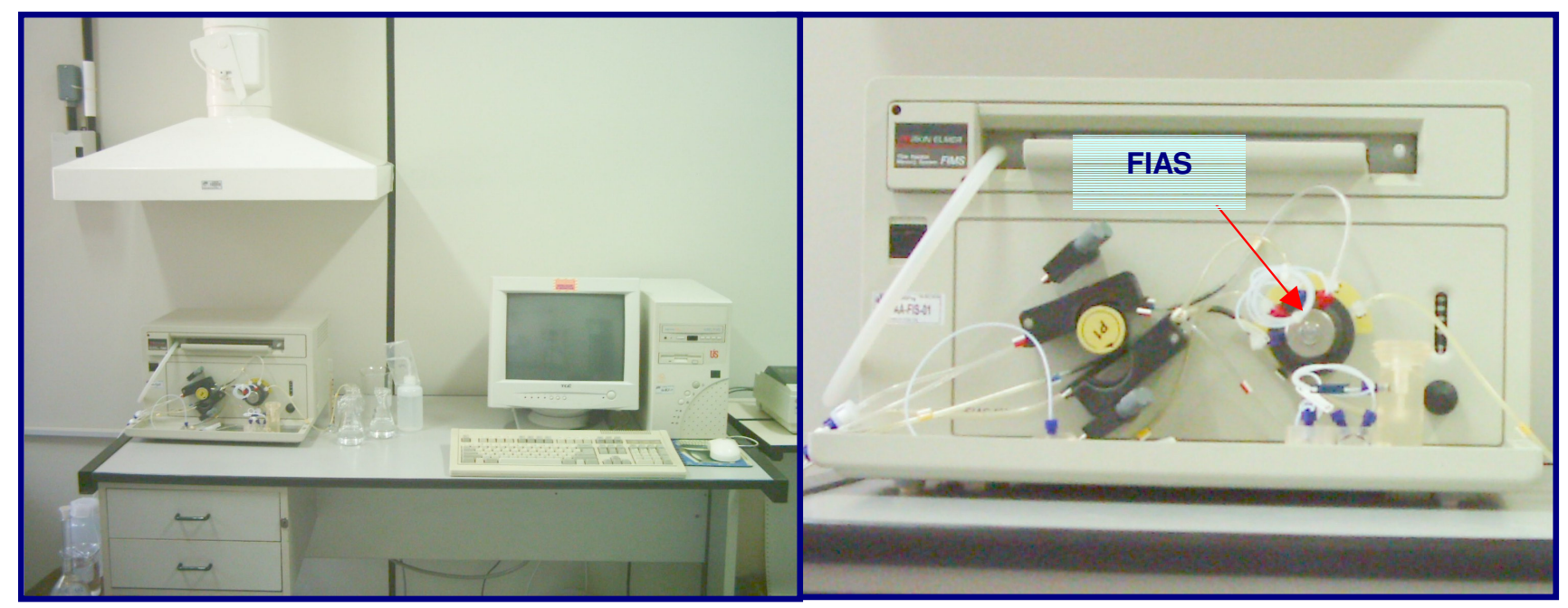

Figura 8 . Equipamento utilizado na determinação do Hg (FIMS 100 - Flow Injection Mercury System, Perkin Elmer).

O componente central do sistema de injeção de fluxo é a válvula de injeção de fluxo (FIAS). A válvula injeta um volume definido e reprodutível de amostra para dentro de um canal condutor, juntamente com o agente carreador (ácido clorídrico - $\mathrm{HCl}$ ) e o agente redutor $\left(\mathrm{SnCl}_{2}\right)$. Por meio da bomba transportadora, o carreador, a amostra e o redutor, são transportados até o "tubo misturador" (manifold em inglês) que permite a mistura e as possíveis reações químicas. O Hg, agora reduzido a $\mathrm{Hg}^{0}$ pelo cloreto estanoso $\left(\mathrm{SnCl}_{2}\right)$, pode então, ser conduzido ao detector e quantificado.

\subsection{Análise por ativação neutrônica (AAN)}

A disponibilidade tanto de isótopos radioativos naturais como artificiais tornou possível o desenvolvimento de métodos analíticos que são ao mesmo tempo sensíveis e específicos. Esses procedimentos caracterizam-se, em geral, pela exatidão e larga aplicabilidade; além disso, alguns deles minimizam ou eliminam a necessidade de separações químicas que são requeridas em outros métodos. Os métodos radioquímicos podem ser classificados pela origem da radioatividade, em três tipos: traçadores radioativos, diluição isotópica e análise por ativação. Nesta última, a atividade é induzida por irradiação com partículas adequadas (mais comumente nêutrons térmicos obtidos em 
um reator nuclear), de um ou mais elementos da amostra. A radioatividade resultante é então medida (IAEA, 1990, Skoog e col., 2002).

A AAN, de uma maneira geral, possui alta sensibilidade, ausência de riscos de contaminação da amostra após a irradiação, especificidade, alta precisão e alta exatidão. É uma técnica vantajosa por fornecer uma análise mutielementar simultânea e não destrutiva, sendo um dos métodos mais importantes dentre os disponíveis para a análise qualitativa e quantitativa de elementos traço. Possui a capacidade de determinação de muitos elementos com alta sensibilidade, abaixo do nível de $\mu \mathrm{g}$ $\mathrm{kg}^{-1}$ (Fávaro e. col., 2000b), independência da matriz, e capacidade inerentes para se obter altos níveis de precisão comparada a outras técnicas analíticas para a determinação de elementos traço. Contudo, a probabilidade de que a reação nuclear ocorra, a abundância isotópica do núcleo alvo e a meia-vida do radioisótopo formado devem ter uma ordem de grandeza suficiente para que a análise se torne viável. A Figura 9 apresenta uma representação esquemática de uma reação nuclear por meio da interação do nêutron com um núcleo alvo.

Devido à sua sensibilidade e precisão inerentes, a AAN tem sido extensivamente aplicada a estudos nutricionais (dietas, alimentos, grãos, sementes, vegetais, leites e fórmulas lácteas, leveduras, etc...) e estudos relacionados à saúde (biomedicina, tecidos animais e humanos, bile, sangue e componentes sangüíneos, ossos, drogas e medicamentos, cabelos, urina, etc...), entre outros (Maihara, 1998, Fávaro, 2000ª , Vasconcellos e col., 2000, Soares e col., 2002).

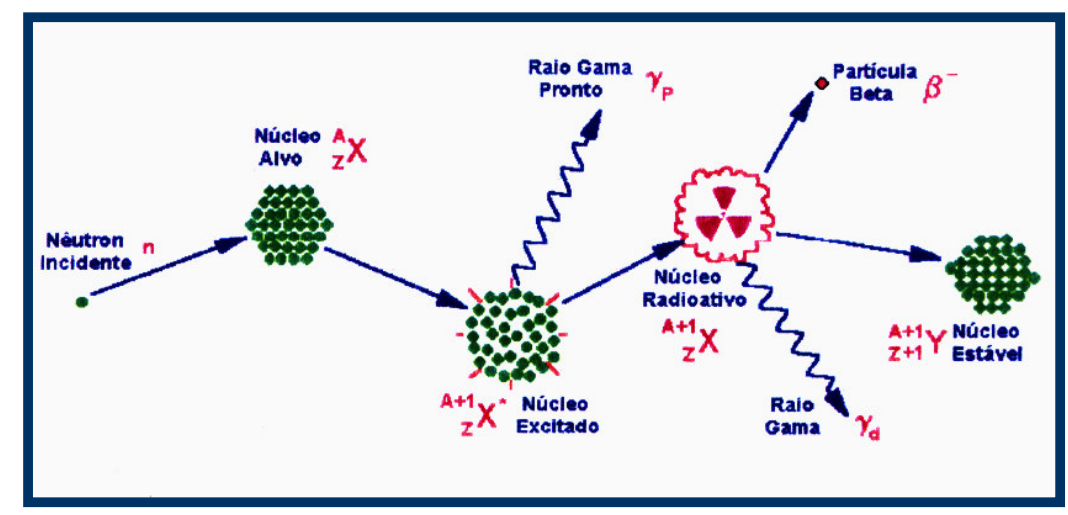

Figura 9 . Representação esquemática da interação do nêutron com um núcleo alvo (adaptado de Pellegati, 2000). 
O método de AAN pode ser comparativo ou absoluto. No presente trabalho, utilizou-se o método comparativo. Neste caso, a amostra é irradiada juntamente com um padrão de composição o mais similar possível, nas mesmas condições. Após a irradiação, amostra e padrão são medidos no mesmo detector, o que permite que a concentração desconhecida possa ser diretamente calculada a partir das taxas de contagens da amostra e do padrão e conhecendo-se a massa de ambos, utilizando-se para o cálculo a seguinte expressão:

$$
C_{a i}=\frac{\left(\mathrm{A}_{\mathrm{ai}} \cdot m_{p} \cdot C_{p i}\right) \mathrm{e}^{\lambda\left(\mathrm{t}_{\mathrm{a}}-t_{p}\right)}}{A_{p i} \cdot \mathrm{m}_{\mathrm{a}}} \quad \text { (Equação 1) }
$$

Onde:

- $\mathrm{C}_{\mathrm{ai}}$ : Concentração do elemento i na amostra;

- $\mathrm{C}_{\mathrm{pi}}$ : Concentração do elemento i no padrão;

- $\mathrm{A}_{\mathrm{ai}}$ : Atividade do elemento i na amostra;

- $\mathrm{A}_{\mathrm{pi}}$ : Atividade do elemento i no padrão;

- $\mathrm{m}_{\mathrm{a}}$ e $\mathrm{m}_{\mathrm{p}}$ : massas da amostra e padrão, respectivamente;

- $\lambda$ : constante de decaimento do radioisótopo;

- $\mathrm{t}$ : tempo de resfriamento.

As medidas da radiação gama emitida pelos radioisótopos produzidos na irradiação das amostras e padrões são feitas em espectrômetros gama, constituídos de detectores de Ge hiperpuro, acoplados a analisadores multicanais e a microcomputadores para aquisição e processamento dos dados (Figura 10). Para análise dos espectros, foi utilizado o programa de computação VISPECT2, em linguagem TURBOBASIC, desenvolvido pelo Dr. D. Piccot, Saclay, França. 


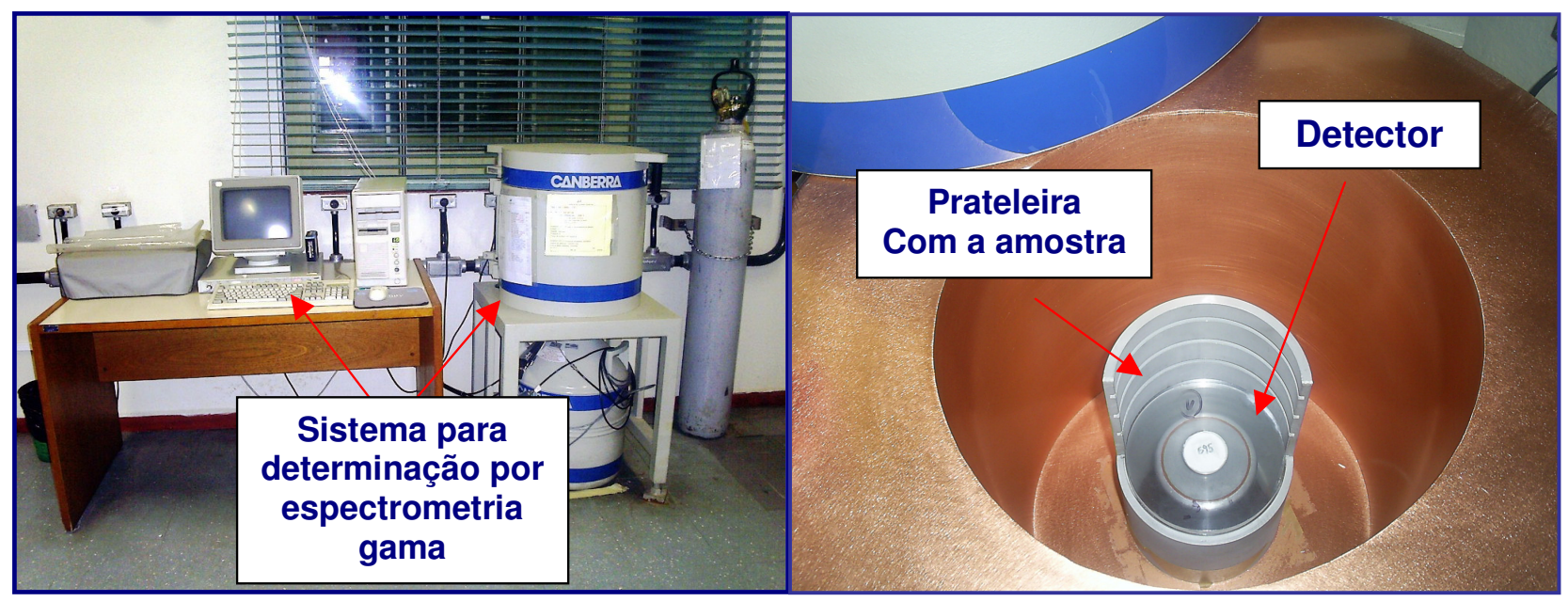

Figura 10 . Espectrômetro de raios gama. 


\section{CAPÍTULO 5}

\section{Procedimento experimental}

\subsection{Locais de coleta}

\subsubsection{Parque Nacional do Jaú (PNJ) e outras comunidades da região Amazônica}

$\mathrm{Na}$ primeira campanha de amostragem realizada em 1999, foram coletadas, por pesquisadores do INPA, 34 amostras de cabelos de crianças em idade pré-escolar e dietas de comunidades do PNJ e 56 amostras de cabelos de crianças em idade pré-escolar e dietas de comunidades fora do Parque.

Nas comunidades Jacaré, Santo Elias, Seringalzinho, Cachoeira e Vista Alegre, foram coletadas amostras de dietas e nas comunidades Cachoeira, Seringalzinho, Vista Alegre e Santo Elias foram coletadas amostras de dietas e cabelo. A Figura 11 exibe a localização das comunidades amostradas no PNJ.

Nas comunidades de Alvarães, Itapiranga, Nhamundá, Nogueira, Novo Airão (próximo ao PNJ), SESI (escola de Manaus) e Urucurituba foram coletadas amostras de dietas e nas comunidades Alvarães, Borba, Itapiranga, Nhamundá e SESI foram coletadas amostras de dietas e cabelo. Estas comunidades não pertencem ao PNJ e foram analisadas com o objetivo de comparar o nível de $\mathrm{Hg}$ encontrados em outras comunidades do Estado do Amazonas com aqueles encontrados em comunidades localizadas dentro do Parque. 


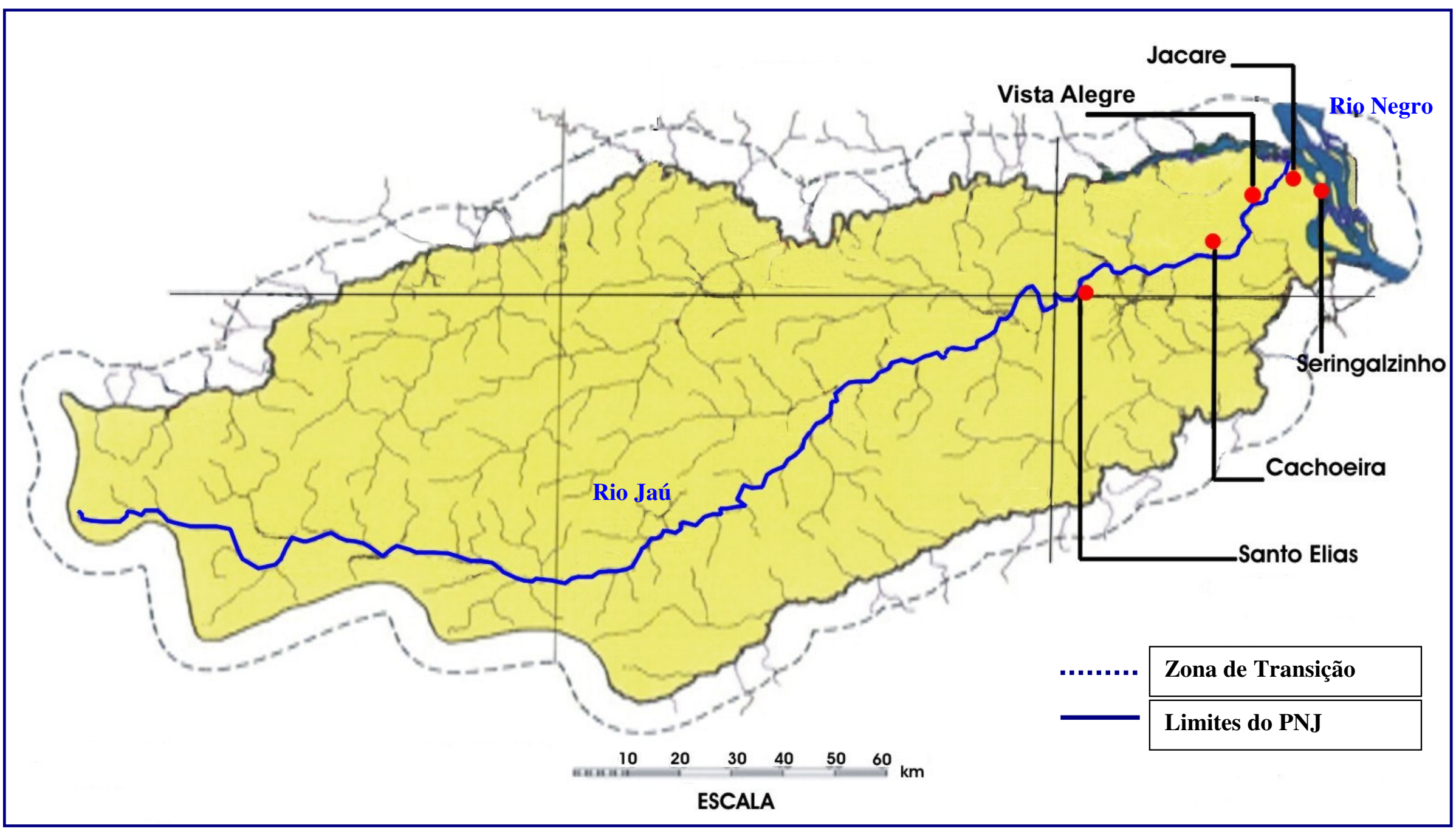

Figura 11 . Mapa das localidades amostradas no Parque Nacional do Jaú (FVA, 98). 


\subsubsection{Manaus}

Na segunda campanha de amostragem realizada em 2004, foram coletadas 202 amostras de cabelos de crianças em idade pré-escolar e 64 amostras de peixes na cidade de Manaus, por pesquisadores do INPA.

Peixes - Os peixes foram adquiridos junto às embarcações pesqueiras no Porto da Central de Abastecimento do Amazonas - CEASA, oriundos dos lagos Ariaú e Puraquequara e rios dos municípios de Autazes, Codajás, Careiro e Terra Nova. Todos foram avaliados quanto aos indicadores de qualidade para pescados e caracteres organolépticos externos (olhos, guelras e escamas). Em seguida, foram transportados para o Laboratório de Nutrição e Físico-Química de Alimentos da CPCS - INPA, em caixas isotérmicas, intercalados entre camadas de gelo. Foram selecionadas 12 espécies de peixes, entre predadoras e não predadoras, mais consumidas pela população local: Aracu (Schizodar sp), Aruanã (Osteoglossum bicirrhossum), Branquinha (Curimata laticeps), Curimatá (Prochilodus nigricans), Jaraqui (Prochilodus insignis sp), Pacu (Mylossoma spp), Pescada (Plagioscion spp), Piratitinga (Piractus brachypomum), Sardinha (Triportheus elongatus spp), Surubim (Pseudoplalystoma fasciatum), Tambaqui (Colossoma macropomum) e Tucunaré (Cichla ocellaris spp).

Cabelos - As amostras de cabelos foram coletadas de crianças em idade pré-escolar residentes nos bairros mais populosos, obedecendo à distribuição espacial adotada administrativamente pela Prefeitura Municipal da capital:

- Alvorada - Zona Centro-Oeste;

- $\quad$ Cidade Nova - Zona Norte;

- Compensa - Zona Oeste;

- Flores - Zona Centro-Sul;

- Japiim - Zona Sul;

- São José Operário - Zona Leste.

A Figura 12 traz a localização dos bairros amostrados na cidade de Manaus.

Esse estudo foi realizado com crianças (pré-escolares e escolares) voluntárias, após o consentimento dos pais e/ou responsáveis e aprovação da Comissão de Ética do Instituto Nacional 
de Pesquisa da Amazônia - INPA e IPEN/CNEN, residentes em diferentes comunidades da região Amazônica e da cidade de Manaus.

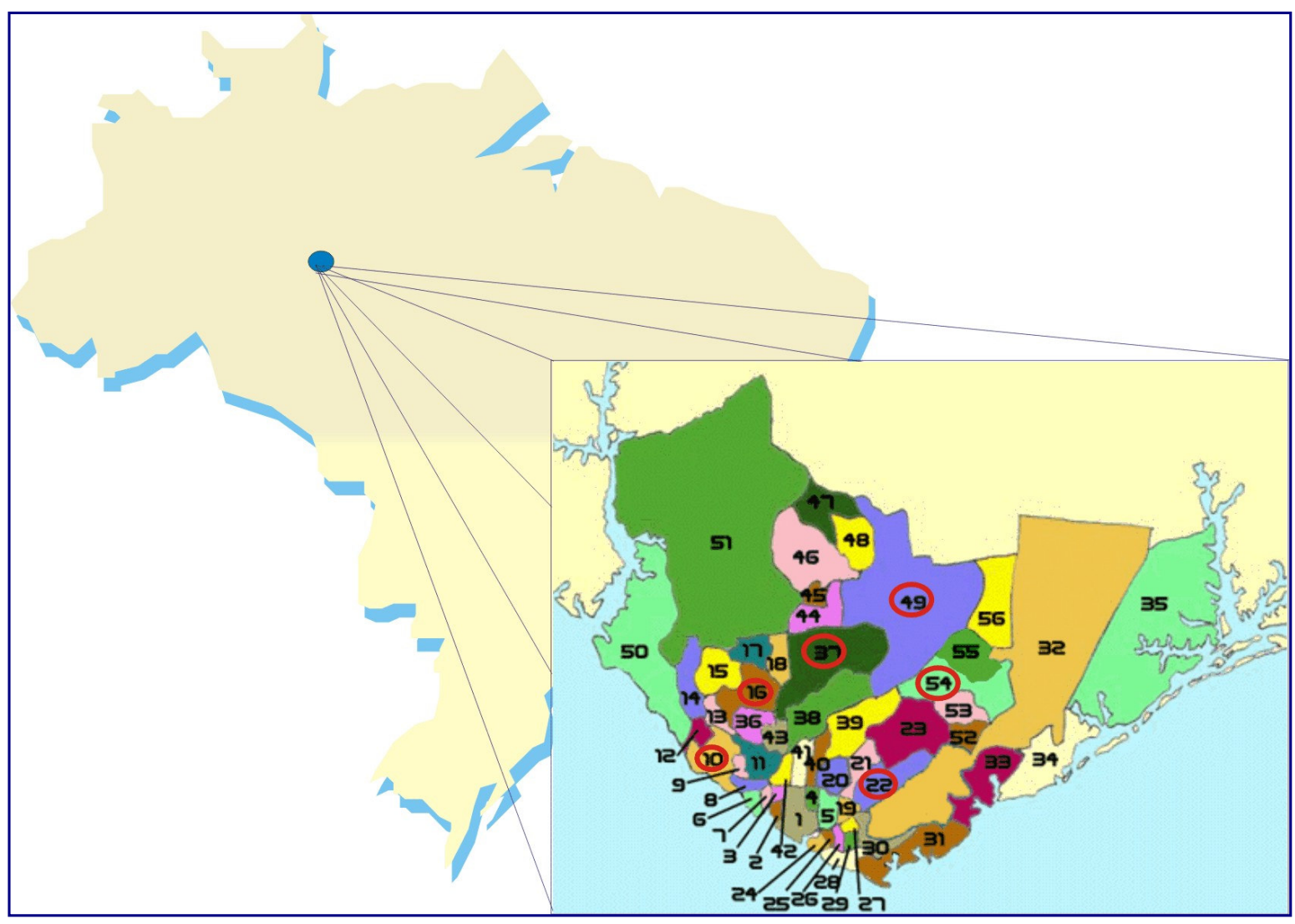

Figura 12 . Mapa de Manaus e bairros (bairros amostrados em destaque).

\section{Legenda:}

1- Centro

2- Aparecida

3- Pres. Vargas

4- Praça 14 de Janeiro

5- Cachoeirinha

6- São Raimundo

7- Glória

8- Santo Antônio

9- Vila da Prata

10. Compensa

11- São Jorge

12- Santo Agostinho

13- Nova Esperança

14- Lírio do Vale

15- Planalto
16-Alvorada

17- Redenção

18- Bairro da Paz

19- Raiz

20- São Francisco

21- Petrópolis

22. Japiim

23- Coroado

24- Educandos

25- Santa Luzia

26- Morro da Liberdade

27- Betânia

28- Col. Oliveira Machado

29- São Lázaro

30- Crespo
31- Vila Buriti

32- Distrito Industrial

33- Mauazinho

34- Col. Antônio Aleixo

35- Puraquequara

36- D. Pedro I

37. Flores

38- Parque 10

39-Aleixo

40- Adrianópolis

41- N. Senhora das Graças

42- São Geraldo

43- Chapada

44- Col. Santo Antônio

45- Novo Israel
46- Col Terra Nova

47- Santa Etelvina

48- Monte das Oliveiras

49- Cidade Nova

50- Ponta Negra

51- Tarumã

52- Armando Mendes

53- Zumbi dos Palmares

54-São José Operário

55- Tancredo Neves

56- Jorge Teixeira 
As características das crianças da cidade de Manaus, participantes do estudo, são apresentadas na Tabela 4.

Tabela 4 . Características das crianças da cidade Manaus participantes do estudo, segundo o sexo (valores médios)

\begin{tabular}{c|c|c|c}
\hline Características & $\begin{array}{c}\text { Masculino } \\
(\mathbf{n}=\mathbf{8 1})\end{array}$ & $\begin{array}{c}\text { Feminino } \\
(\mathbf{n}=\mathbf{1 2 1})\end{array}$ & $\begin{array}{c}\text { População Total } \\
(\mathbf{n}=\mathbf{2 0 2})\end{array}$ \\
\hline Idade média (anos) & 5 anos & 5 anos & 5 anos \\
\hline Peso $\mathbf{( k g )}$ & $16 \mathrm{~kg}$ & $15 \mathrm{~kg}$ & $15 \mathrm{~kg}$ \\
\hline Altura $(\mathbf{c m})$ & $93 \mathrm{~cm}$ & $91 \mathrm{~cm}$ & $91 \mathrm{~cm}$ \\
\hline
\end{tabular}

No presente estudo, as mães ou responsável, foram inquiridos quanto às características demográficas e socioeconômicas da família com o objetivo de obter o maior número de informações possíveis a respeito da criança participante do estudo. Idade, peso, hábitos alimentares, endereço, escolaridade, renda familiar mensal e classe social, sendo que para esta última optou-se pelo escore da Associação Brasileira de Empresas de Pesquisa (ABEP), compreendendo a escolaridade da pessoa com maior renda do domicílio; número de rádios disponíveis no domicílio; posse de geladeira, máquina de lavar roupas e televisão em cores; e disponibilidade de água encanada dentro de casa e de sanitário com descarga. Com base nestas variáveis, a ABEP criou escores que variam de 0 (pior) a 34 (melhor), e este escore foi transformado em categorias que correspondem à classe social. Famílias com escore entre 0 e 5 pertencem à classe E, entrı Capitulo 5 classe $\mathrm{D}$, entre 11 e 16 à classe $\mathrm{C}$, entre 17 e 20 à classe B2, entre 21 e 24 à classe B1, entre 25 e 29 à classe $\mathrm{A} 2$ e, os mais abastados, com escore de 30 a 34, são classificados como de classe A (ABEP, 2003).

\subsection{Amostragem e preparação das dietas, peixes e cabelos}

\subsubsection{Dietas}

As dietas foram coletadas em residências a partir de uma busca ativa nos municípios, por meio da porção em duplicata, de 24 horas de consumo total, em sacos plásticos, previamente 
limpos, lavados com água e detergente líquido comum e deixados em ácido nítrico a $20 \%$ por 24 horas. Foram então enxaguados várias vezes com bastnte água deionizada e por fim com água MilliQ e devidamente etiquetados com o nome da criança selecionada. Cerca de 5 - 10 dietas de crianças na faixa etária de 12 a 60 meses (pré-escolares) foram coletadas e misturadas formando um pool de dietas, para cada comunidade amostrada. No presente trabalho, optou-se por fazer um pool das dietas de cada comunidade frente à monotonia do cardápio. Foi solicitado separar uma duplicata de toda refeição efetuada (após o processo de cocção) e as análises foram realizadas em uma réplica dos alimentos realmente consumidos pelos indivíduos.

Considerando o baixo nível sócio-econômico, foi distribuída uma mini cesta básica (arroz, feijão, óleo, café e açúcar), como forma de indenização às famílias que participaram do estudo e sem informação prévia, para que não houvesse mudanças na dieta diária. Em todos os municípios, houve contato prévio com o prefeito e líderes comunitários.

Imediatamente após a coleta, as dietas foram congeladas e transportadas ao Laboratório de Nutrição e Físico-Química de Alimentos do INPA, para análises. As amostras foram secas em estufa com circulação de ar forçada a $60^{\circ} \mathrm{C}$, pulverizadas em moinho elétrico, homogeneizadas e acondicionadas em potes de polietileno previamente desmineralizados (banho de ácido nítrico 30\% e enxágüe com água deionizada por seis vezes) e enviadas ao Laboratório de Análise por Ativação Neutrônica (LAN/CRPq) do IPEN/CNEN - São Paulo, para análise de minerais e elementos traço. No INPA foram realizadas as análises de composição centesimal (teor de lipídeos, proteínas, carboidratos, cinzas e umidade) e energia das dietas, seguindo metodologias já estabelec Capitulo 5 Association of Official Analytical Chemists (AOAC) (1998).

Durante as coletas foram feitas anotações, discriminando o tipo e a quantidade de alimentos consumidos em cada comunidade. Com relação à sua composição, as dietas analisadas do PNJ e demais comunidades continham:

\section{Comunidades PNJ}

- Santo Elias: peixe, farinha, pão, café, pedaços de cana, ingá (fruto), caroço de bacaba (espécie de coco), carne de caça, arroz, ovo de tracajá (de quelônio) e bolacha água e sal. 
- Vista Alegre: peixe, farinha, feijão, macarrão, arroz, bolacha água e sal, cubiu (fruto), charque, maxixe, banana e beiju.

- Cachoeira: peixe, farinha, cará, bolacha água e sal, macarrão, café, carne em conserva, abacaxi e banana.

- Seringalzinho: farinha, peixe, arroz, café, bolacha água e sal, feijão, macarrão e abacate.

- Jacaré: peixe, farinha, bolacha água e sal, ovo de tracajá, feijão, arroz, pão, café e frango.

Demais comunidades

- Alvarães: pão, arroz, farinha, peixe, feijão, ovo, banana, leite, café, macaxeira, carne, bolacha, pupunha (fruto), tapioca, bolinho de trigo, din-din (tipo de sorvete), macarrão, buriti (quelônio), suco, melancia, nescau, bolo de macaxeira, margarina, beiju (farinha de macaxeira), tomate, manga, graviola, conserva, abacate, jerimum (abóbora), batata, bombom, chá, farinha de tapioca.

- Itapiranga: pão, biscoito, manteiga, farinha, arroz, peixe, carne, frango, café, leite, banana, maçã, maracujá, manga, feijão, macarrão, ovo, fígado, salsicha, jerimum (abóbora), cará, repolho, mamão, abacate, jambo (fruto pequeno e negro), melancia, pupunha, abacaxi, carambola, bucho (vísceras), calabreza, mocotó, tartaruga (quelônio), pato, farinha de tapioca, beiju (farinha de macaxeira), refresco, beterraba, pepino, tomate, bolinho, feijão verde, mingau, pamonha, chá.

- Nogueira: farinha, pão, arroz, pimenta de cheiro, goiaba, banana, feijão, macarrão, açaí, uva, bacaba, caldo de cana, coco, pupunha, abacate, tomate, maionese, bolinho de trigo, biscoito salgado, peixe.

- Novo Airão: farinha, arroz, pão, manteiga, biscoito, macarrão, feijão, peixe, frango, carne, ovo, porco, salsicha, tracajá (quelônio), café, leite, mingau, achocolatado, laranja, banana, mamão, limão, goiaba, tomate, batata, repolho, maxixi (espécie de pepino), macaxeira, cenoura, farinha de tapioca, beiju (farinha 
de macaxeira), pastel, bolo, din-din (tipo de sorvete), milhitos (salgadinho de milho), castanha.

- Nhamundá: farinha, pão, arroz, peixe, feijão, café com leite, carne, banana, macarrão, bolacha, tapioca e ovo.

- SESI: nescau, pão, manteiga, arroz, suco de cupuaçu, feijão, farinha, carne, batata, repolho, ervilha, cebola.

\subsubsection{Análises físico-químicas}

- Determinação do teor de Fibras

Não foi possível realizar a determinação do teor de fibras nas dietas devido ao INPA estar em reformas no período do presente estudo. Portanto, para as dietas das crianças considerou-se a fração fibra junto com o carboidrato para o cálculo da energia total das dietas.

- Determinação do teor de proteínas

A determinação do teor de proteínas foi obtida pela determinação de nitrogênio total presente nas dietas, pelo processo de digestão Kjeldahl. Este método baseia-se na decomposição da matéria orgânica com ácido sulfúrico $\left(\mathrm{H}_{2} \mathrm{SO}_{4}\right)$ concentrado, seguida da destilação da amônia, sendo o nitrogênio dosado por titulação volumétrica. Para a conversão do nitrogênio total em proteína adotou-se o fator 6,25 de acordo com a AOAC (1998).

- Determinação do teor de lipídeos

O teor de lipídeos foi determinado em extrator intermitente de Soxhlet, utilizando-se o éter de petróleo como solvente de acordo com a AOAC (1998).

- Determinação do teor de umidade

Determinado por secagem da amostra em estufa a $60^{\circ} \mathrm{C}$, até obter peso constante (AOAC, 1998).

- Determinação do teor de cinzas 
A determinação do teor de cinzas nas dietas foi feita por incineração após deixar as amostras em mufla à $550^{\circ} \mathrm{C}$ por oito horas (AOAC, 1998).

\subsubsection{Peixes}

O beneficiamento foi viabilizado na planta piloto de pescados da Coordenação de Pesquisas em Tecnologia de Alimentos - CPTA - INPA que consistiu no processo de lavagem dos peixes em água corrente, evisceração, lavagem, retirada do excesso de água, acondicionamento em sacos plásticos e estocagem em freezer a $-18^{0} \mathrm{C}$ até o momento das preparações e análises.

Objetivando a obtenção de concentração desejável de ingredientes utilizados nas preparações, foram realizados testes preliminares no Laboratório de Nutrição e Físico-Química de Alimentos do INPA, em relação à quantidade de sal, óleo para fritura e farinha de trigo para o peixe frito e quantidade de água de adição, sal no peixe e na água de cocção e colorau para o peixe cozido. Para cada preparação foram utilizados três exemplares de cada espécie com exceção da Pescada, Pirapitinga, Surubim, Tambaqui e Tucunaré, que por serem peixes de médio porte, foram divididos em postas.

Após a separação da parte comestível fez-se um pool de amostras para cada espécie a fim de submetê-lo a posterior análise química. Os exemplares de peixe in natura foram filetados e homogeneizados formando um pool de amostras. As amostras foram secas em estufa a $60^{\circ} \mathrm{C}$, até obter peso constante, homogeneizadas e analisadas.

Além do peixe in natura foram analisados também três formas de preparo de peixes (frito, cozido e assado) comumente utilizadas pela população de Manaus, descritas a seguir. O objetivo foi avaliar a perda de $\mathrm{Hg}$ total e elementos de interesse nutricional em pescados, após os processos de cocção usualmente utilizados pela população.

\subsubsection{Modos de preparação dos peixes (cocção)}

\section{Peixe frito}

Os peixes temperados foram empanados com farinha de trigo, pesados e submetidos à fritura em óleo de soja, seguido da avaliação da parte comestível. 


\section{Peixe cozido}

Os ingredientes: cebola, alho, tomate, pimenta de cheiro, cheiro verde e colorau foram refogados em uma colher de chá (3g) de azeite, seguida da adição do peixe em postas: água fervente e sal.

\section{Peixe assado}

Os peixes, após terem sido temperados com sal e pesados, foram assados em brasa por tempo variado, dependendo do tipo e tamanho do peixe.

\subsubsection{Cabelos}

Para a coleta das amostras de cabelo foi utilizada uma tesoura de aço inox, limpa com etanol p. a. da Merck, retirando-se o cabelo da área occipital, bem próximo ao escalpo, realizado conforme o protocolo recomendado pela Agência Internacional de Energia Atômica (IAEA, 1987). O cabelo foi então picotado com uma tesoura de aço inoxidável em segmentos de aproximadamente $0,5 \mathrm{~mm}$ de comprimento e transferido para um béquer limpo para ser submetido ao procedimento seqüencial de lavagem com água e acetona e, posterior secagem a temperatura ambiente. A Figura 13 traz a preparação seqüencial das amostras de cabelos. 


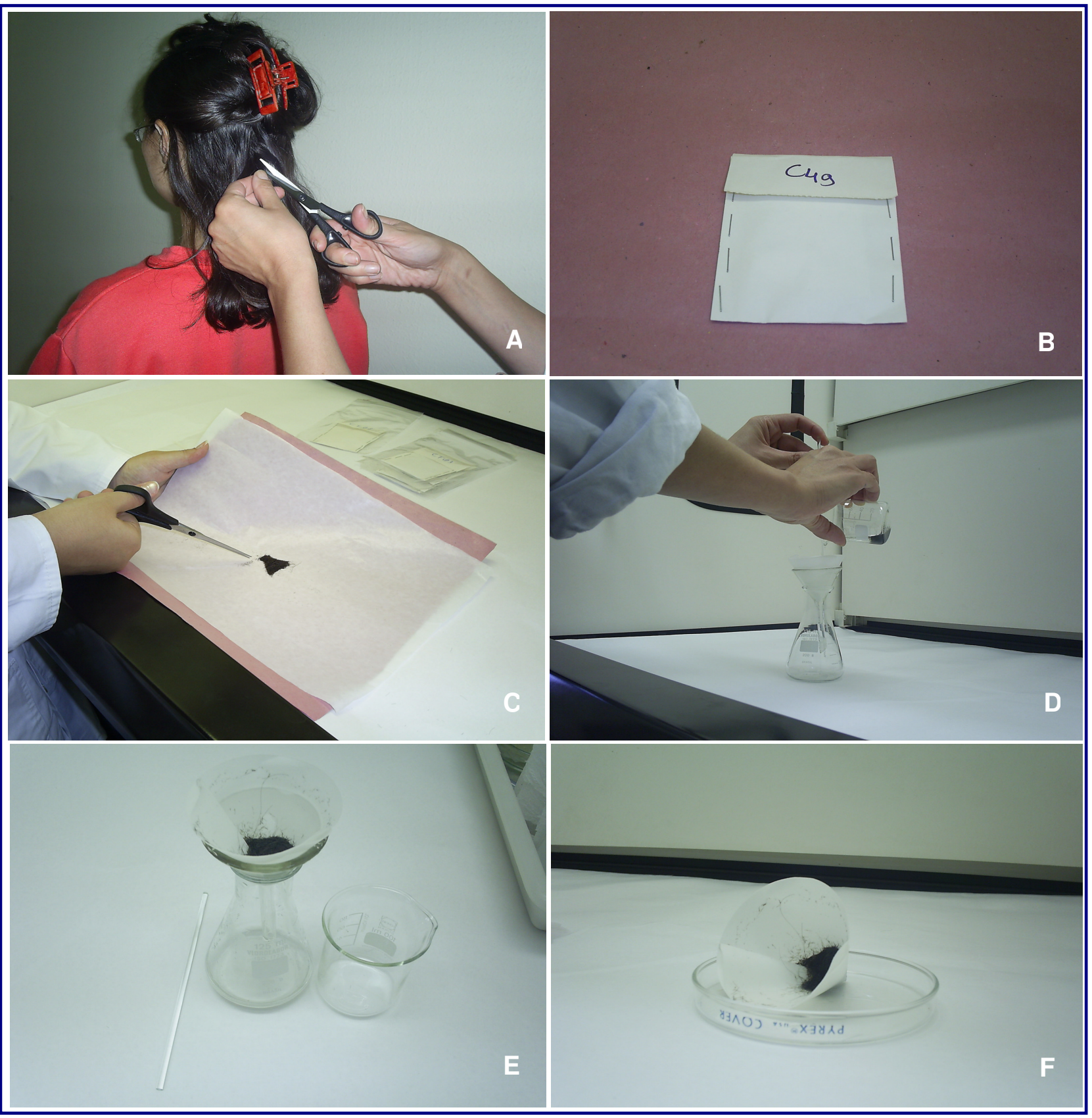

A - o corte de cabelo na região occipital ; B - a amostra de cabelo na embalagem devidamente identificada; C - a amostra cortada em pequenos segmentos; D - a transferência do cabelo para o papel de filtro depois da amostra de cabelo ser imersa em acetona; E - exibe a etapa de lavagem (dois enxágües seqüências com água Milli-Q e um último enxágüe novamente com acetona); $\mathbf{F}$ - a etapa de secagem na capela.

Figura 13 . Etapas de preparo das amostras de cabelo para análise. 


\subsection{Análises Químicas}

\subsubsection{Análise de mercúrio total e metilmercúrio - CV AAS}

\subsubsection{Procedimento analítico (cabelo, dieta e peixe)}

\section{Digestão e análise das amostras de dietas e peixes}

Para a análise das dietas e peixes (amostras e/ou materiais de referência), pesou-se de 0,3 a 0,5 g de amostra diretamente em um frasco de Teflon fechado da Savilex, com capacidade de 50 mL. Em seguida, foram adicionados $8 \mathrm{~mL}$ de ácido nítrico $\left(\mathrm{HNO}_{3}\right)$ conc. com baixo teor de $\mathrm{Hg}$ e 4 $\mathrm{mL}$ de $\mathrm{H}_{2} \mathrm{SO}_{4}$ conc., ambos da Merck, e deixados reagir com as amostras durante toda a noite. No dia seguinte, os frascos foram colocados no bloco digestor da Tecnal e as amostras foram digeridas em sistema fechado, em temperatura de $90^{\circ} \mathrm{C}$, durante três horas (Figura 14). Esse procedimento foi necessário para permitir uma digestão completa das amostras, devido ao alto teor de gordura

presente. Após a digestão, os frascos foram colocados em banho de gelo até o completo resfriamento e, em seguida, adicionados, $500 \mu \mathrm{L}$ de solução de dicromato de potássio $\left(\mathrm{K}_{2} \mathrm{Cr}_{2} \mathrm{O}_{7}\right)$ $10 \%(\mathrm{~m} / \mathrm{v})$, para a estabilização do $\mathrm{Hg}$. Completou-se o volume até a marca de $50 \mathrm{~mL}$.

Determinação de $\mathbf{H g}$ total - a determinação de $\mathrm{Hg}$ total foi realizada por CV AAS, equipamento FIMS-100, da Perkin Elmer.

Validação da metodologia - a validação da metodologia para a determinação de $\mathrm{Hg}$ total em dieta e peixes foi feita por meio da análise de material de referência com valor certificado. 


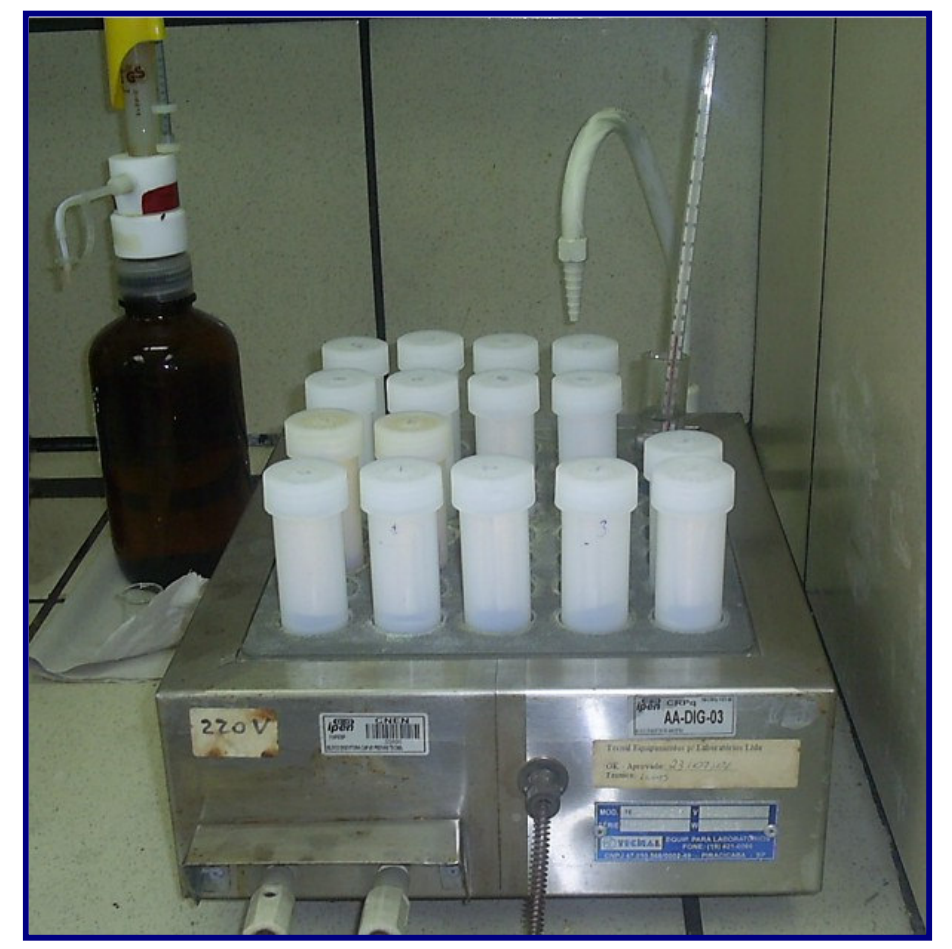

Figura 14 . Frascos de Teflon fechados da Savilex no bloco digestor da Tecnal.

\section{Digestão e análise das amostras de cabelos}

Procedimento similar ao utilizado na digestão das dietas, foi utilizado para matriz de cabelo. Para a análise das amostras ou materiais de referência, foram pesadas cerca de 0,1 a $0,15 \mathrm{~g}$ de amostra diretamente em um frasco de Teflon fechado da Savilex, com capacidade de 18,2 mL. Após a pesagem, foram adicionados $4 \mathrm{~mL}$ de $\mathrm{HNO}_{3}$ conc. e $2 \mathrm{~mL}$ de $\mathrm{H}_{2} \mathrm{SO}_{4}$ conc., ambos da Merck, e deixados reagir com as amostras durante toda a noite. No dia seguinte, os frascos foram colocados no bloco digestor. As amostras foram digeridas em sistema fechado, em temperatura de $90^{\circ} \mathrm{C}$, durante três horas. Após a digestão, os frascos foram colocados em banho de gelo até o completo resfriamento e, em seguida, adicionados $250 \mu \mathrm{L}$ de solução de $\mathrm{K}_{2} \mathrm{Cr}_{2} \mathrm{O}_{7} 10 \%$ (m/v), para a estabilização do Hg. Completou-se o volume até a marca de 18,2 mL.

Determinação Hg total - a determinação de $\mathrm{Hg}$ total foi realizada por CV AAS, equipamento FIMS-100, da Perkin Elmer. 
Validação da metodologia - a validação da metodologia para a determinação de $\mathrm{Hg}$ total em cabelo foi feita por meio da análise de material de referência com valor certificado.

\section{Determinação de $\mathrm{MeHg}$}

O método selecionado é baseado na lixiviação ácida e separação de $\mathrm{Hg}$ orgânico e inorgânico numa coluna de troca iônica, seguido pela espectrometria de absorção atômica com geração de vapor frio (CV $\mathrm{AAS}$ ). $\mathrm{O} \mathrm{HCl} 6 \mathrm{M}$ extrai quantitativamente o $\mathrm{MeHg}$ dos tecidos biológicos e uma coluna de troca iônica é usada para separar o $\mathrm{MeHgCl}$ não iônico (que passa através da resina de troca iônica) do complexo $\mathrm{HgCl}_{4}{ }^{-2}$, que fica retido na coluna. Uma vez separado, o MeHg tem que ser decomposto para $\mathrm{Hg}^{2+}$, porque o $\mathrm{SnCl}_{2}$ pode reduzir somente o $\mathrm{Hg}$ iônico inorgânico. A decomposição pode ser feita por radiação ultra violeta (UV) ou decomposição ácida. No presente trabalho, testaram-se ambas as decomposições com bons resultados, mas optouse pela digestão ácida ${ }^{9}$. A Figura 15 mostra esquematicamente o procedimento para a análise de $\mathrm{MeHg}$ em diversas matrizes.

Para a determinação do $\mathrm{MeHg}$, pesou-se cerca de 0,15 g de material de referência e/ou amostra de cabelo diretamente em um frasco com tampa de rosca e capacidade de $15 \mathrm{~mL}$. Após a pesagem, foram adicionados $10 \mathrm{~mL}$ de $\mathrm{HCl} 6 \mathrm{M}$ e deixados reagir durante toda a noite. Os frascos foram envolvidos em papel alumínio para impedir a passagem de luz e evitar a decomposição do MeHg. No dia seguinte, os frascos foram colocados no agitador por duas horas e posteriormente centrifugados por aproximadamente $10 \mathrm{~min}$ a uma velocidade de $3000 \mathrm{rpm}$. Após a centrifugação, o sobrenadante foi percolado através de uma resina de troca iônica condicionada previamente na forma $\mathrm{Cl}^{-}$(1 mL de resina de troca iônica - Dowex 1-X8, 200-400 mesh). O material eluído da coluna foi recolhido em frascos de Teflon com tampa, com capacidade de $50 \mathrm{~mL}$ e adicionados então $4 \mathrm{~mL}$ de $\mathrm{HNO}_{3}$ conc. e $2 \mathrm{~mL}$ de $\mathrm{H}_{2} \mathrm{SO}_{4}$ conc. com a finalidade de decompor o MeHg. Após a digestão, os frascos foram colocados em banho de gelo até o completo resfriamento e, em seguida, adicionados $500 \mu \mathrm{L}$ de solução de $\mathrm{K}_{2} \mathrm{Cr}_{2} \mathrm{O}_{7} 10 \%$ (m/v), para a estabilização do $\mathrm{Hg}$. Completou-se o volume até a marca de $50 \mathrm{~mL}$.

\footnotetext{
${ }^{9}$ Há duas possibilidades para decompor o MeHg: pela irradiação UV ou pela digestão ácida. A decomposição pela irradiação UV é simples e efetiva, mas pode demorar horas e deve ser conduzida em tubos de quartzo ou frascos de Teflon transparentes (pois ambos refletem a luz UV). A digestão ácida é mais rápida e também efetiva, deve ser feita em tubos de digestão fechados e devido a grande quantidade de ácidos utilizada, o branco do reagente é mais alto, mas não alto o suficiente que prejudique a determinação do $\mathrm{Hg}$.
} 
Determinação Hg total - a determinação de $\mathrm{Hg}$ total foi realizada por CV AAS, equipamento FIMS-100, da Perkin Elmer.

Validação da metodologia - a validação da metodologia para a determinação de $\mathrm{MeHg}$ em cabelo foi feita por meio da análise de material de referência com valor certificado para MeHg.

Os valores de limite de detecção do método e cálculo da incerteza associada à determinação de mercúrio serão discutidos no Capítulo 6. 


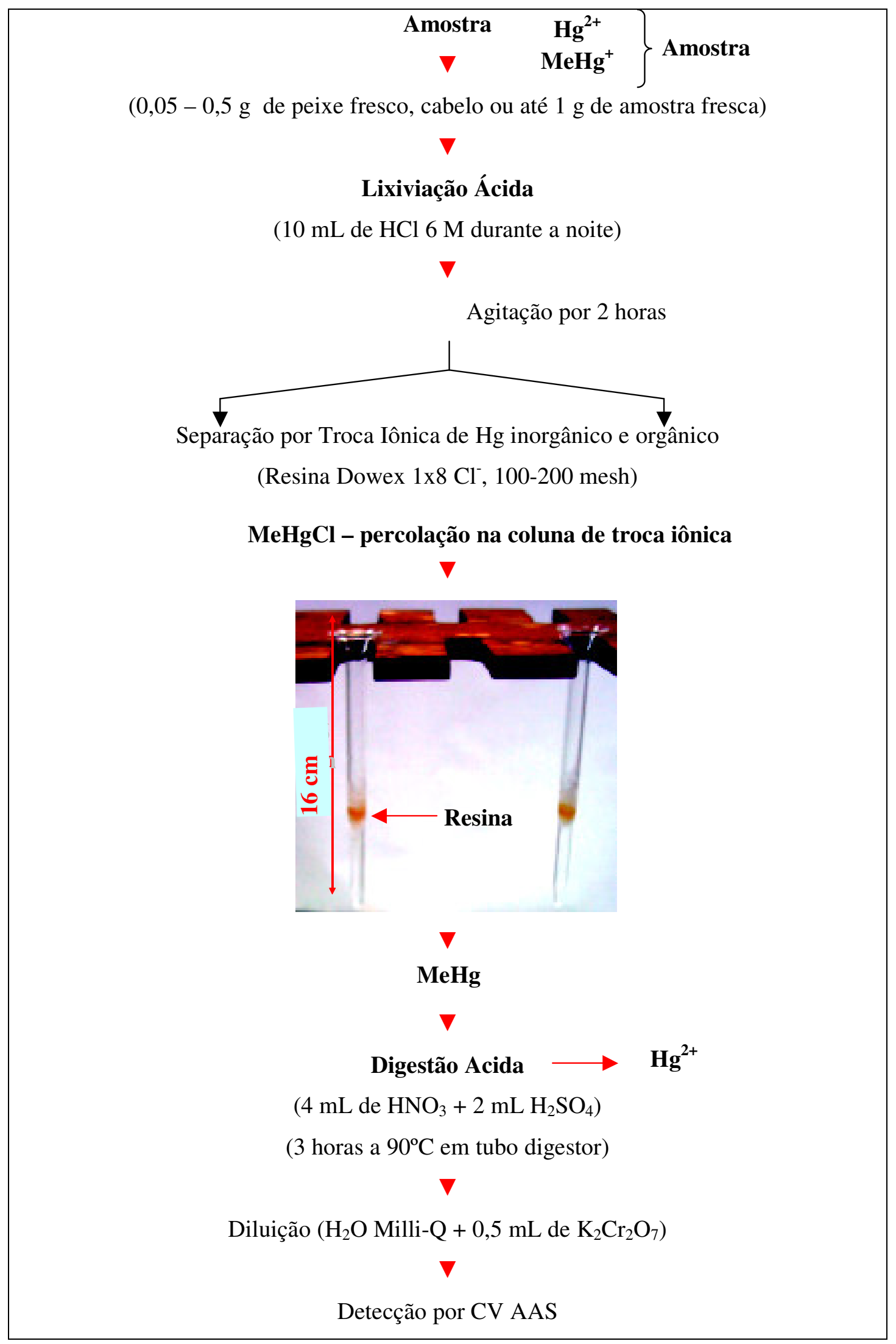

Figura 15 . Seqüência esquemática da separação do MeHg. 


\subsubsection{Determinação de elementos traço e essenciais - Análise por Ativação Neutrônica}

\subsubsection{Preparo dos padrões sintéticos}

Os padrões sintéticos dos elementos analisados foram preparados a partir de soluções padrão da marca SPEX CERTIPREP, diluídas a concentrações apropriadas.

Para diminuir o número de padrões a serem manipulados nas análises, foram preparadas soluções multielementares, agrupando as soluções individuais, conforme as características químicas e nucleares desses elementos.

\subsubsection{Irradiação e medida da radioatividade}

Cerca de $200 \mathrm{mg}$ das amostras de dietas e peixes, $150 \mathrm{mg}$ dos materiais de referência e os padrões sintéticos dos elementos de interesse, foram irradiados conjuntamente. As amostras (duplicata) e os padrões foram submetidos a irradiações por 8 horas, no reator de pesquisas do IPEN/CNEN-SP, sob um fluxo de nêutrons térmicos de $10^{12} \mathrm{n} \mathrm{cm}^{-2} \mathrm{~s}^{-1}$. Nessas condições foi possível a determinação dos seguintes elementos: $\mathrm{Ca}, \mathrm{Fe}, \mathrm{K}, \mathrm{Na}$, Se e Zn.

As atividades induzidas foram medidas em espectrômetros de raios gama após tempos de decaimentos adequados. A primeira medida foi realizada após um tempo de decaimento de 5 a 7 dias, por aproximadamente duas horas para amostras e materiais de referência, e de 30 minutos para os padrões sintéticos. Nessas condições os seguintes radioisótopos de $T_{1 / 2}$ intermediária: ${ }^{47} \mathrm{Ca},{ }^{42} \mathrm{~K}$ e ${ }^{24} \mathrm{Na}$ foram determinados.

A segunda medida foi realizada após um tempo de decaimento de quinze a vinte dias, com um tempo de contagem de 15 horas para as amostras e materiais de referência e de cerca de 30 minutos, para os padrões sintéticos. Nessas condições os seguintes radioisótopos de $\mathrm{T}_{1 / 2}$ longa: ${ }^{59} \mathrm{Fe}$, ${ }^{75} \mathrm{Se}, \mathrm{e}^{65} \mathrm{Zn}$ foram determinados.

As medidas da radiação gama emitida foram feitas em espectrômetros gama, constituídos de detectores de Ge hiperpuro, acoplados a analisadores multicanais e eletrônica associada e a microcomputadores para aquisição e processamento dos dados, com resolução em energia para os picos do ${ }^{57} \mathrm{Co}-121,97 \mathrm{keV}(1,08 \mathrm{keV})$ e ${ }^{60} \mathrm{Co} 1332,49 \mathrm{keV}(1,90 \mathrm{keV})$. Para análise dos espectros, 
foi utilizado o programa de computação VISPECT2, em linguagem TURBOBASIC, desenvolvido pelo Dr. D. Piccot, Saclay, França.

\subsubsection{Validação da metodologia}

A validação da metodologia quanto à precisão e a exatidão, foram realizadas por meio da análise dos materiais de referência Orchard Leaves (OL) (NIST SRM 1571), Tomato Leaves (TL) (NIST SRM 1573 ${ }^{\mathrm{a}}$ ) e Oyster Tissue (OT) (NIST SRM 1566b).

\subsubsection{Cálculo do $\mathrm{Z}$ score}

Os valores de Z-score obtidos para os elementos analisados nos materiais de referência Orchard Leaves (NIST 1571- OL), Tomato Leaves (NIST 1573a - TL) e Oyster Tissue (NIST SRM 1566b - OT), foram calculados conforme descrito por Bode (1996), calculado pela Equação 2:

$$
z_{i}=\frac{C_{i}-C_{r e f_{i}}}{\sqrt{\sigma^{2}{ }_{i}+\sigma_{r e f}^{2}}} \quad \text { (Equação 2) }
$$

Onde:

$\mathrm{C}_{\mathrm{i}}=$ concentração obtida para o elemento i no material de referência;

$\mathrm{C}_{\text {ref,i }}=$ valor de concentração certificado ou de consenso para o elemento $\mathrm{i}$;

$\sigma_{1}=$ incerteza da concentração obtida para o elemento i no material de referência;

$\sigma_{\text {ref, }}=$ incerteza do valor certificado ou de consenso para o elemento $\mathrm{i}$.

Se $|z| \leq 3$, o valor de concentração obtido deve estar no intervalo de confiança de $99 \%$ do valor de concentração certificado. 


\subsubsection{Limite de detecção}

Uma característica de desempenho importante para qulaquer metologia analítica é o limite de detecção (LD).

Como citado anteriormente, representa a mais baixa concentração da substância em exame que pode ser detectada com um certo limite de confiabilidade utilizando um determinado procedimento experimental.

Neste estudo, para o cálculo do limite de detecção para a AAN, foram utilizados os critérios de Currie (1968; 1998):

$$
L D=3,29 \sigma_{0} \longrightarrow \sigma_{0}=\frac{\sqrt{R F}}{t v} \quad \text { (Equação 3) }
$$

Onde:

- $\quad \mathrm{RF}=$ número de contagens da radiação de Fundo sob o pico do analito;

- $\mathrm{Tv}=$ tempo total de medição da amostra (tempo vivo).

A expressão fornece LD em termos de taxas de contagem, sendo necessário convertê-las para unidades de concentração pela divisão por fatores como massa da amostra, massa e atividade do padrão.

Os limites de detecção para amostras foram calculados isoladamente, partindo-se dos espectros dos materiais de referência utilizados na análise.

Os valores dos limites de detecção para os elementos analisados por análise por ativação neutrônica, calculados pelo critério de Currie, são apresentados na Tabela 5. 
Tabela 5 . Valores dos limites de detecção para os elementos analisados por Análise por Ativação Neutrônica (AAN) $\left(\mathrm{mg} \mathrm{kg}^{-1}\right)$

\begin{tabular}{c|c}
\hline Elemento & LD \\
\hline $\mathrm{Ca}$ & 76 \\
$\mathrm{Fe}$ & 1,0 \\
$\mathrm{~K}$ & 345 \\
$\mathrm{Na}$ & 20 \\
$\mathrm{Se}\left(\mu \mathrm{g} \mathrm{Kg}^{-1}\right)$ & 65 \\
$\mathrm{Zn}$ & 0,5 \\
\hline
\end{tabular}

\subsection{Resumo do procedimento experimental}

As principais análises relacionadas aos procedimentos analíticos deste trabalho para as amostras do PNJ e de Manaus estão representadas no diagrama abaixo (Figura 21).

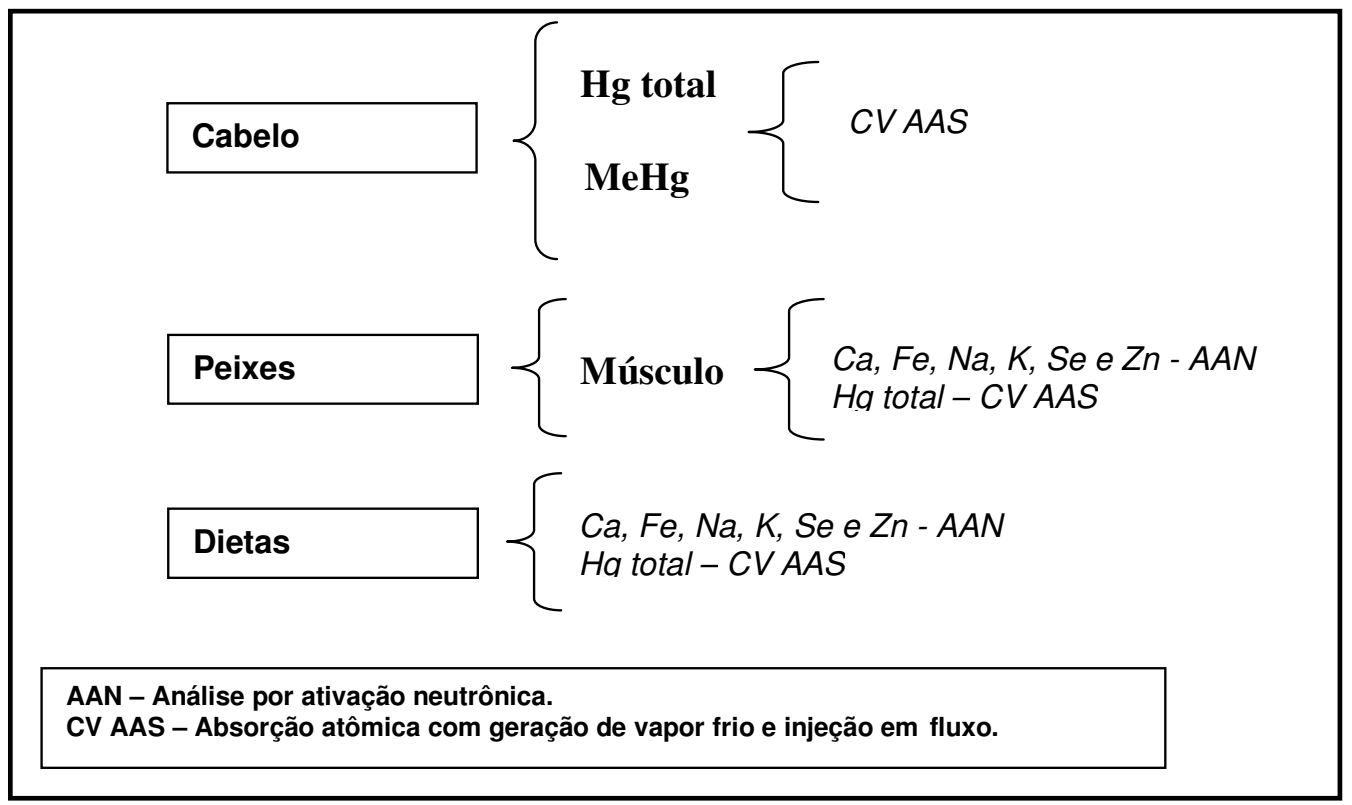

Figura 16. Resumo das análises químicas realizadas e as respectivas amostras. 


\section{CAPÍTULO 6}

\section{Quantificação de mercúrio por CV AAS (dietas, peixes e cabelos)}

\subsection{Validação de resultados analíticos}

Validação é a comprovação, através de meios, critérios e objetivos que um laboratório possui, para demonstrar que o ensaio que executa conduz a resultados com confiabilidade metrológica e qualidade gerencial.

O Instituto Nacional de Metrologia, Normalização e Qualidade Industrial (INMETRO), no DOQ-CGCRE-008 (2002) discute os critérios utilizados na validação de um método analítico, os quais devem ter: especificidade e seletividade, linearidade, exatidão, precisão, robustez, faixa de trabalho e faixa linear, limite de detecção (LD), limite de quantificação (LQ) e incerteza da medição.

Um método que produz resposta para apenas um analito é chamado específico e aquele produz resposta para vários analitos, mas que pode distinguir a resposta de um analito da de outros, é chamado seletivo.

A linearidade é a habilidade de um método analítico em produzir resultados que sejam diretamente proporcionais à concentração do analito em amostras, em uma dada faixa de concentração. Na determinação de $\mathrm{Hg}$, quando necessário, foi preparado um branco com adição de concentrações variadas do analito, com o objetivo de identificar, inicialmente, por observação visual, a faixa linear aproximada e os limites superiores e inferiores da faixa de trabalho, confirmando a linearidade.

A robustez de um método de ensaio mede a sensibilidade que este apresenta em face de pequenas variações. A metodologia para análise de $\mathrm{Hg}$ total mostrou-se mais robusta que a metodologia para determinação do $\mathrm{MeHg}$, verificando-se que uma das etapas mais críticas na variação desta sensibilidade é na etapa de preparação das colunas de troca iônica.

A incerteza é um atributo que qualifica a medição, quantitativamente e permite comparação de resultados. Para a avaliação da incerteza de medição é necessário ter o pleno conhecimento e domínio do processo de medida, e, sempre que possível estabelecer um modelo matemático que 
represente o processo físico. Para tanto, é importante considerar os inúmeros fatores envolvidos nas etapas intermediárias do procedimento analítico: calibração da balança (incerteza referente à massa), material volumétrico (incerteza do volume e alíquotas), calibração e curva analítica.

A seguir, são apresentadas algumas das etapas mais importantes na determinação de $\mathrm{Hg}$ utilizando a espectrometria de AAS com geração de vapor frio, uma avaliação da metodologia utilizada, realizada por meio da participação em programa de intercomparação da Agência Internacional de Energia Atômica (IAEA) e uma discussão sobre as incertezas associadas à determinação do $\mathrm{Hg}$ (calculadas de acordo com as normas adotadas pela EURACHEM/CITAC GUIDE (2002).

\subsubsection{Curva de calibração}

Calibração de um método analítico é o processo matemático e estatístico de extrair informação a partir da relação entre a resposta obtida pelo método e a quantidade (massa, volume, concentração) do analito de interesse.

Neste trabalho, as soluções foram preparadas a partir de uma solução estoque de $\mathrm{Hg}$, preparada a partir de $\mathrm{Hg}$ metálico de alta pureza $(99,99995 \%)$ dissolvido em $\mathrm{HNO}_{3}$ $\left(1000 \mathrm{mg} \mathrm{mL}^{-1}\right)$. A partir dessa solução estoque, preparou-se a solução estoque $2\left(1255 \mu \mathrm{g} \mathrm{L}^{-1}\right)$ e a partir desta, pipetou-se volumes apropriados diretamente nos frascos de Teflon e nas mesmas condições das amostras. Foram preparadas soluções padrões diluídas para cada experiência e as concentrações utilizadas dependeram das amostras analisadas, sendo utilizadas sempre cinco concentrações diferentes para a construção da curva de calibração.

\subsubsection{Exatidão e precisão}

A exatidão de um método é definida como sendo a concordância entre o resultado de um ensaio e o valor de referência aceito como convencionalmente verdadeiro. Os procedimentos geralmente utilizados para avaliar a exatidão são feitos pela análise de materiais de referência com valores certificados. 
A precisão é definida como grau de concordância entre resultados de medições independentes, em torno de um valor central, efetuadas várias vezes em uma amostra homogênea, sob condições experimentais pré-estabelecidas.

A validação da metodologia para a determinação de $\mathrm{Hg}$ total em dieta e peixe, neste trabalho, foi feita por meio da análise de materiais de referência com valores certificados, a saber: Fish Tissue (IAEA-407), Orchard Leaves (NIST SRM 1571), Typical Diet (NIST SRM 1548 a) e Dogfish Muscle (DORM-1, NRCC). A validação da metodologia para a determinação de Hg total e MeHg em cabelo, foi feita por meio da análise de materiais de referência com valores certificados, a saber: Human Hair Spiked (IAEA 085) e Human Hair (IAEA 086).

A metodologia estabelecida mostrou-se eficaz, exibindo uma boa exatidão e precisão, conforme resultados apresentados no capítulo 7. Serão apresentados também gráficos de controle para as análises de $\mathrm{Hg}$, podendo-se assim, avaliar o comportamento do sistema em função do tempo (rastreabilidade).

\subsubsection{Participação em exercício de intercomparação}

Com o objetivo de avaliar a metodologia utilizada na determinação de $\mathrm{Hg}$ e $\mathrm{MeHg}$, bem como, a qualidade final das análises, participou-se do programa de intercomparação da Agência Internacional de Energia Atômica (IAEA) o World-Wide Intercomparison Exercise for the Determination of Trace Elements and Methylmercury in Tuna Fish Flesh Homogenate (IAEA-436), realizado no período de outubro de 2004 a julho de 2005. A performance dos laboratórios participantes foi avaliada através de gráficos Z-score e os resultados foram publicados Report $\mathrm{n}^{\circ}$ IAEA/AL/157-MEL/77 Matine Envirnoment Laboratory, 4 quai Antoin $1^{e r}$, MC 98000 Monaco. Os gráficos de Z-score com os resultados obtidos nesse programa de intercomparação para as análises de $\mathrm{Hg}$ total e MeHg encontram-se nos Anexos (Figura 17 e 18, representados pelo código 30).

Os valores obtidos para o exercício de intercomparação para determinação de $\mathrm{Hg}$ total e MeHg em um material candidato a material de referência são apresentados na Tabela 6. 
Tabela 6 . Hg total e MeHg no material Tuna Fish Flesh Homogenate (IAEA-436)

\begin{tabular}{c|c|c|c|c}
\hline $\begin{array}{c}\text { Material de Referência } \\
\text { (média } \pm \mathbf{s . d} .)\end{array}$ & $\begin{array}{c}\text { Valor Encontrado } \\
\left(\mathbf{m g ~ k g}^{-1}\right)\end{array}$ & $\begin{array}{c}\text { Valor Certificado } \\
\left(\mathbf{m g ~ k g}^{-1}\right)\end{array}$ & $\begin{array}{c}\text { DPR } \\
\text { (\%) }\end{array}$ & $\begin{array}{c}\text { ER } \\
\text { (\%) }\end{array}$ \\
\hline $\mathrm{Hg}_{\text {total }}\left(\mathrm{mg} \mathrm{kg}^{-1}\right)$ & $3,75 \pm 0,04$ & $4,19 \pm 0,36$ & 1,1 & 10,5 \\
$\mathrm{MeHg}\left(\mathrm{mg} \mathrm{kg}^{-1}\right)$ & $3,66 \pm 0,05$ & $3,68 \pm 0,42$ & 1,4 & 0,5 \\
\hline
\end{tabular}

\subsubsection{Limite de detecção e limite de quantificação}

O limite de detecção (LD) é a menor concentração do analito em uma amostra que pode ser detectada, mas não necessariamente quantificada, sob determinadas condições experimentais.

O LD para análise de $\mathrm{Hg}$ neste trabalho foi determinado diretamente da curva de calibração, construída usando-se a técnica de regressão e considerando-se um nível de confiança de $95 \%$.

De acordo com Haswell (1991), o limite de detecção para equipamentos de absorção atômica e injeção de fluxo pode ser determinado a partir das Equações (4) e (5).

$$
\begin{array}{ll}
A_{L d}=A_{0} \cdot 3 \cdot \sigma_{0} & (\text { Equação } 4) \\
C_{L d}=\frac{A_{L d}-A_{0}}{a} & (\text { Equação 5) }
\end{array}
$$

Onde:

* Add : absorbância do limite de detecção;

* $\mathrm{A}_{0}$ : média dos valores obtidos para a absorbância da solução branco;

* $\sigma_{0}$ : desvio padrão da média dos valores obtidos para a absorbância da solução branco;

* $\mathrm{C}_{\mathrm{Ld}}$ : concentração do limite de detecção;

* a: coeficiente angular.

O valor encontrado para o limite inferior de detecção foi da ordem de $0,01 \mathrm{ng} \mathrm{mL}{ }^{-1}$, sendo este resultado compatível com valores encontrados na literatura para determinação do Hg (Horvat, 1996; Skoog e col., 2002). 
O limite de quantificação (LQ), também conhecido como limite de determinação, indica a menor concentração do analito que pode ser detectada por um método qualquer que está sendo empregado, com um nível aceitável de precisão e veracidade ("trueness"). Pode ser considerado como sendo a concentração do analito correspondente ao valor da média do branco mais 5,6 ou 10 desvios-padrão (Xavier, 2006).

O valor encontrado para o limite de quantificação para este trabalho é da ordem de $1 \mathrm{ng} \mathrm{mL}^{-}$

1. Isso resultou em um LQ final para o procedimento de determinação de $\mathrm{Hg}$ em materiais biológicos da ordem de $1 \mathrm{ng} \mathrm{g}^{-1}$.

A Tabela 7 apresenta os métodos mais freqüentemente utilizados para a determinação de $\mathrm{Hg}$ e seus respectivos limites de detecção (adaptado de Horvat, 1996). 
Tabela 7 . Métodos para a determinação de $\mathrm{Hg}$ e limites de detecção

\begin{tabular}{|c|c|}
\hline Método & $\begin{array}{c}\text { Limite de Detecção } \\
\text { (Relatado) }\end{array}$ \\
\hline Método Calorimétrico & $0,01-0,1 \mu g^{-1}$ \\
\hline \multicolumn{2}{|l|}{ Espectrometria de Absorção Atômica: } \\
\hline Forno de grafite (GF AAS) & $1 \mathrm{ng} \mathrm{g}^{-1}$ \\
\hline Vapor Frio (CV AAS) & $0,01-1 \mathrm{ng} \mathrm{g}^{-1}$ \\
\hline Espectrometria de Fluorescência Atômica - Vapor Frio (CV AAS) & $0,001-0,1 \mathrm{ng} \mathrm{g}^{-1}$ \\
\hline \multicolumn{2}{|l|}{ Análise por Ativação com Nêutrons: } \\
\hline Instrumental (INAA) & $1-10 \mathrm{ng} \mathrm{g}^{-1}$ \\
\hline Radioquímica (RNAA) & $0,01-1 \mathrm{ng} \mathrm{g}^{-1}$ \\
\hline \multicolumn{2}{|l|}{ Cromatografia Gasosa: } \\
\hline Detector de Captura Eletrônica & $0,01-0,05 \mathrm{ng} \mathrm{g}^{-1}$ \\
\hline Detector de Emissão Atômica & $\approx 0,05 \mathrm{ng} \mathrm{g}^{-1}$ \\
\hline Espectrometria de Massa & $0,1 \mathrm{ng} \mathrm{g}^{-1}$ \\
\hline CV AAS/CVAFS & $0,01-0,05 \mathrm{ng} \mathrm{g}^{-1}$ \\
\hline \multicolumn{2}{|l|}{ Cromatografia Líquida de Alta Eficiência: } \\
\hline Detector de Ultra-violeta & $1 \mathrm{ng} \mathrm{mL}^{-1}$ \\
\hline CV AAS & $0,5 \mathrm{ng} \mathrm{mL}^{-1}$ \\
\hline CV AFS & $0,08 \mathrm{ng} \mathrm{mL}^{-1}$ \\
\hline Eletroquímico & $0,1-1 \mathrm{ng} \mathrm{mL}^{-1}$ \\
\hline \multicolumn{2}{|l|}{ Plasma Acoplado Indutivamente: } \\
\hline Espectrometria de Massa (ICP MS) & $0,01 \mathrm{ng} \mathrm{mL}^{-1}$ \\
\hline Espectrometria de Emissão Atômica (ICP AES) & $2 \mathrm{ng} \mathrm{mL}^{-1}$ \\
\hline Espectrometria Foto-Acústica & $0,05 \mathrm{ng}$ \\
\hline Fluorescência de Raio X & $5 n g g^{-1}-1 \mu g g^{-1}$ \\
\hline Métodos Eletroquímicos & $0,1-1 \mu g^{-1}$ \\
\hline Analisador de Filme de Ouro & $0,05 \mu g^{-1}$ \\
\hline
\end{tabular}

Fonte: Adaptado de Horvat, 1996. 


\subsection{Incertezas associadas à determinação de mercúrio}

\section{Definição de incerteza}

Os resultados de um trabalho são usados para estimar rendimento do processo, comparar resultados, avaliar conformidade de materiais em relação a especificações e/ou limites legais. Como existe sempre uma margem de dúvida sobre o resultado de qualquer medição, é necessário determinar a incerteza associada a cada resultado ${ }^{10}$.

Para avaliar a incerteza global, é necessário considerar uma por uma, as várias fontes de incerteza e tratá-las separadamente para obter a correspondente contribuição de cada fonte. Cada uma das contribuições individuais para a incerteza é referida como uma componente da incerteza.

Como o valor mensurado $\mathbf{Y}$ é sempre determinado a partir de $\mathbf{N}$ outras grandezas $\mathbf{X}$ :

$$
Y=f\left(X_{i}, X_{i i}, X_{i i i} \ldots X_{N}\right)
$$

Vários conceitos estatísticos devem ser utilizados para a identificação das fontes de incerteza, como média aritmética, variância experimental e desvio padrão experimental da média.

As incertezas podem ser expressas em, pelo menos três formas (EURACHEM/CITAC GUIDE, 2002):

- Incerteza padrão $\left(\mathbf{u}_{\mathbf{i}}\right)$ - é expressa como desvios padrões. A incerteza padrão nos remete à incerteza da média $(\mathrm{u}(y))$.

- Incerteza combinada $\left(\mathbf{u}_{\mathbf{c}}\right)$ - é uma combinação de todas as fontes de incertezas de um método analítico, possuindo um nível de confiança de $68 \%$. Utiliza o método da raiz quadrada da soma dos quadrados da incerteza padrão de todos os componentes.

- Incerteza expandida (U) - é a incerteza derivada da incerteza combinada, porém reportada com $95 \%$ ou $99 \%$ de nível de confiança. A incerteza padrão combinada é multiplicada por uma constante (k) que depende do nível de confiança. Para que seja de $95 \%$ a confiança do valor medido estar no intervalo, $\pm \mathrm{k}_{\mu \mathrm{c}}$, com $\mathrm{k}=2$.

As incertezas podem ser de dois tipos (EURACHEM/CITAC GUIDE, 2002):

\footnotetext{
${ }^{10}$ É preciso distinguir entre erro e incerteza. Erro é definido como a diferença entre um resultado individual e o valor verdadeiro do mensurando. Desta forma, o erro é um valor único. A incerteza, por outro lado, assume a forma de uma faixa e, se estimada para um procedimento analítico e um tipo definido de amostra, pode ser aplicada a todas as determinações descritas por esta forma (EURACHEM/CITAC GUIDE, 2002). 
- Incerteza do tipo A - baseadas em métodos estatísticos. Levam em consideração a distribuição estatística de uma série de medições e são caracterizadas por desvio padrão experimental (dispersão de uma série de medidas). Este tipo de avaliação será normalmente utilizada para obter um valor para a repetitividade ou aleatoriedade de um processo de medição.

- Incerteza do tipo B - métodos de avaliação da incerteza por outros meios que não a análise estatística de série de observações. Incertezas deste tipo são determinadas a partir de informações acessórias e externas ao processo de medição. Estas informações podem ser obtidas de resultados de medições similares anteriores, experiência ou conhecimento do comportamento do instrumento, dados do fabricante, dados fornecidos por certificados de calibração, referência de manuais de instrução, etc.

Um resultado analítico representa sempre uma estimativa do valor real, podendo ser representado por médias, porém, só é representativo quando estiver acompanhado do valor da incerteza associada.

Contudo, para a estimativa da incerteza de um determinando método de análise deve seguir alguns passos específicos, tais como, a especificação do mensurando (na maioria das vezes, uma concentração), identificação das fontes de incertezas e a quantificação das incertezas.

A identificação de todas as possíveis fontes de incerteza é um dos passos chave na avaliação da incerteza. O objetivo é produzir uma lista contendo todas as possíveis fontes de incerteza do método, deixar claro quais as necessidades a serem consideradas no "balanço" ou cômputo das incertezas. 


\section{Fluxograma das etapas do procedimento que envolvem incertezas:}

Os fluxogramas das etapas dos procedimentos que contribuem na incerteza da análise de $\mathrm{Hg}$ encontram-se resumidos na Figura 19. Neste esquema são apresentadas somente as etapas que influenciam no cálculo de concentração do elemento e, conseqüentemente nas suas incertezas associadas. Para tanto, foram consideradas as seguintes etapas do procedimento analítico: pesagem da amostra, digestão, diluição e curva analítica preparada a partir de soluções padrões de calibração.

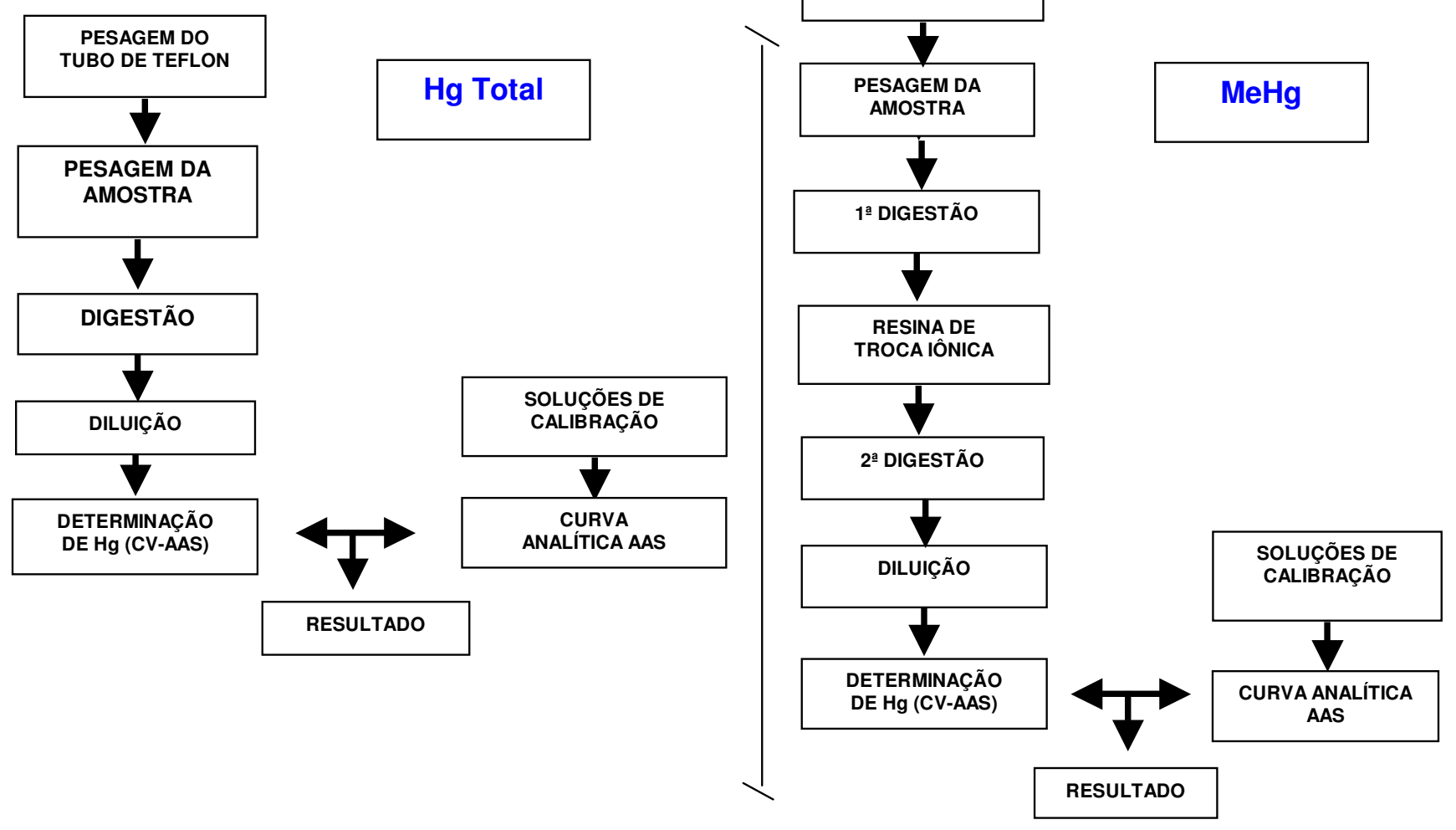

Figura 19. Fluxogramas das etapas do procedimento que contribuem na incerteza da determinação do $\mathrm{Hg}$ e $\mathrm{MeHg}$ em amostras biológicas. 


\section{Relações das variáveis no mensurando (concentração)}

Medidas de materiais de referência certificados são em geral realizadas como parte da validação de um método, constituindo efetivamente uma calibração de todo o procedimento de medição como uma referência rastreável. Como esse procedimento oferece informações sobre o efeito combinado de muitas fontes potenciais de incerteza, ele fornece ótimos dados para a avaliação da incerteza global de um método (EURACHEM/CITAC GUIDE, 2002).

Neste estudo, utilizaram-se materiais de referência com valores certificados e similaridade de matriz com relação às amostras, para a determinação da certeza do método.

A concentração do elemento nos materiais de referência foi calculada pela Equação 6:

$$
C_{H g}=\frac{C_{o} * V_{f}}{R_{i} * m_{a}} \quad \text { Equação } 6
$$

Onde:

* $\mathrm{C}_{\mathrm{Hg}}$ : concentração de $\mathrm{Hg}$ na amostra $\left(\mathrm{ng}^{-1}\right)$;

* $\mathrm{C}_{\mathrm{o}}$ : concentração de $\mathrm{Hg}$ na alíquota do padrão analisada por CV AAS $\left(\mu \mathrm{g} \mathrm{L}^{-1}\right)$;

* $\mathrm{m}_{\mathrm{a}}$ : massa da amostra $(\mathrm{g})$;

* $\mathrm{V}_{\mathrm{f}}$ : volume final após digestão $(\mathrm{mL})$;

* $\mathrm{R}_{\mathrm{i}}$ : taxa de recuperação obtida para o analito.

\section{Diagrama causa e efeito (espinha de peixe)}

Uma das abordagens para obter a lista das possíveis fontes de incerteza é o emprego do "Diagrama de Causa e Efeito", também conhecido como Diagrama de Espinha de Peixe ou Diagrama de Ishikawa. O exame do diagrama pode levar à simplificação, seja agrupando as fontes de incerteza que podem ser consideradas em uma série de repetições, seja removendo termos duplicados. O diagrama simplificado pode, então, ser usado para assegurar que todas as fontes de 
incerteza foram levadas em conta. Os princípios da construção do Diagrama de Causa e Efeito estão descritos na norma NBR ISO 9004 (2000).

As principais fontes de incertezas relacionadas ao procedimento analítico deste trabalho (análise de $\mathrm{Hg}$ total e $\mathrm{MeHg}$ ) estão representadas nos diagramas de causa e efeito abaixo (Figuras 20 e 21). Os ramos principais representam as maiores contribuições e são geralmente os termos que aparecem na equação usada para calcular o resultado das medições. Os ramos secundários representam fatores que contribuem para os ramos principais.

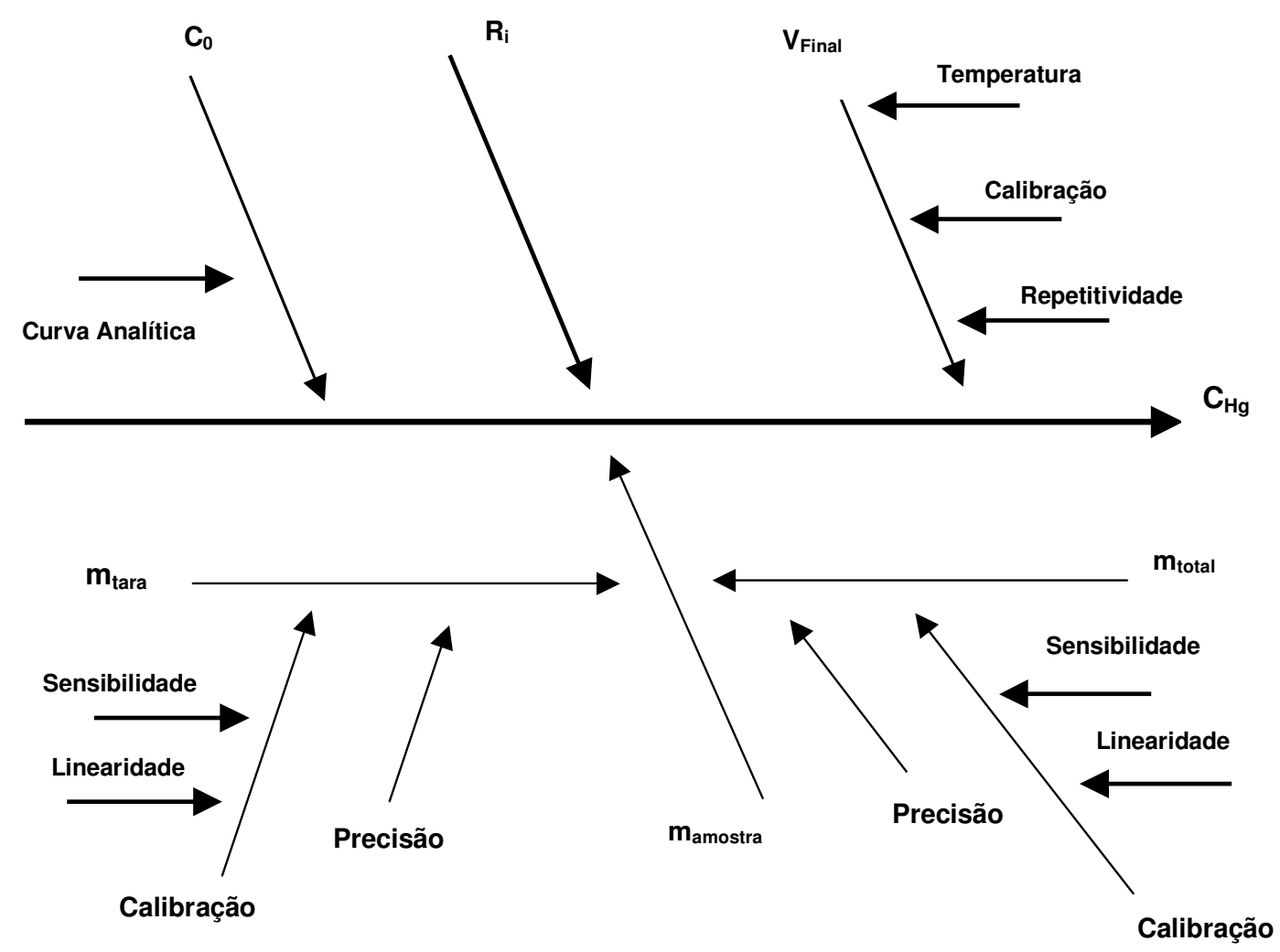

Figura 20 . Diagrama de causa e efeito para o procedimento analítico na determinação de $\mathrm{Hg}$ total em amostras biológicas. 


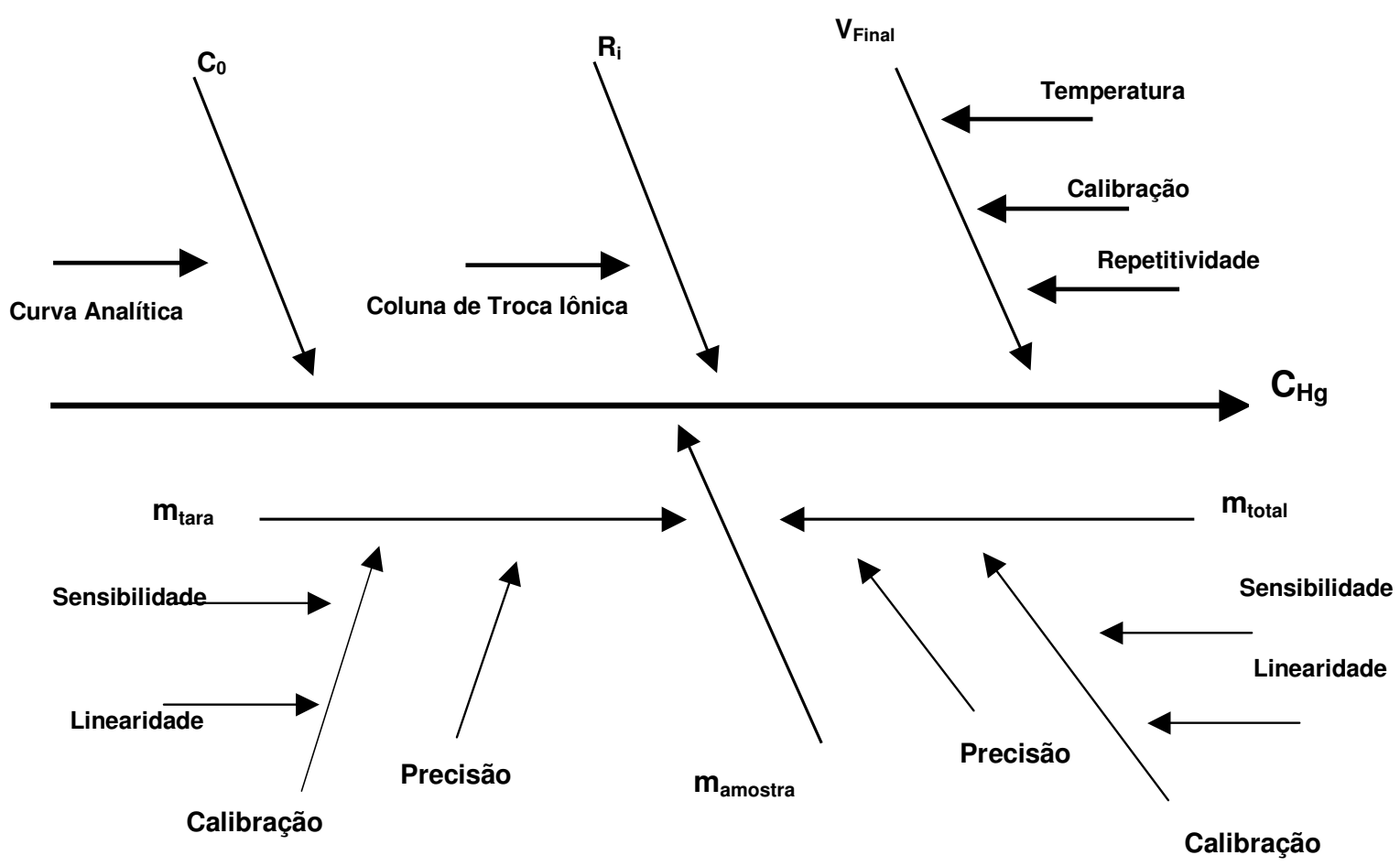

Figura 21. Diagrama de causa e efeito para o procedimento analítico na determinação de $\mathrm{MeHg}$ em amostras biológicas.

\subsubsection{Procedimento para quantificação das incertezas associadas}

\section{Mercúrio total}

\section{a) Incerteza associada à massa $\left(\mathbf{m}_{\mathbf{a}}\right)$ :}

A massa da amostra foi obtida por meio da diferença entre a massa do tubo vazio utilizado na pesagem e a massa do tubo mais amostra. As amostras foram pesadas na balança analítica (resolução de 0,0001g) da marca Ohaus, modelo AR2140 Adventurer (AA-BAL-07).

As medidas de massa estão sujeitas à variabilidade decorrente de pesagens sucessivas (repetividade) e à incerteza de calibração da balança utilizada. A calibração possui duas fontes de incerteza: a linearidade e a sensibilidade da balança, sendo que o efeito desta última pode ser ignorado visto que as medidas foram realizadas na mesma balança em um curto período de tempo. 
A balança possui certificado de calibração nº R041 74601, no qual a incerteza expandida da balança é fornecida como sendo de 0,0001 (95\% de confiança) para um peso padrão de 0,5g. Para se obter a incerteza padrão $\left(\mu_{\mathrm{x} 1}\right)$ da massa, avaliando-se o componente do Tipo B, obtidos a partir de documentação, dividiu-se esse valor por 2,28 (k, valor de abrangência), obtendo-se:

$$
\mu_{\mathrm{x} 1}=0,000044 \mathrm{~g}
$$

Uma outra contribuição da repetitividade na incerteza padrão associada à massa $\left(\mathrm{m}_{\mathrm{a}}\right)$ foi determinada por meio de dez pesagens sucessivas de um peso padrão de verificação, de massa próxima ao valor da massa da amostra $(0,100 \mathrm{~g}$ e $0,500 \mathrm{~g})$, obtida pela pesagem dos pesos com massa próxima ao valor da massa utilizada para a amostra. Utilizou-se a Equação 7 no cálculo desta incerteza, obtendo-se:

$$
\begin{gathered}
\mu_{x 2}=\frac{s}{\sqrt{n}} \\
{\mu \mathrm{x}_{2(0,100)}}=0,00004 \mathrm{~g} \\
{\mu \mathrm{x}_{2(0,500)}}=0,00005 \mathrm{~g}
\end{gathered}
$$$$
\text { Equação } 7
$$

Foi encontrado o mesmo valor para a incerteza padrão associada à massa $\left(\mu_{\mathrm{c}}\left(\mathrm{m}_{\mathrm{a}}\right)=\right)$, tanto para a massa de $0,1 \mathrm{~g}$, quanto para a massa de $0,5 \mathrm{~g}$. Portanto, optou-se por nomear esta incerteza de $\boldsymbol{\mu x}_{\mathbf{2}}$ que representará neste trabalho, as duas massas anteriormente citadas e no cálculo final $\left(\mu_{\mathrm{c}}\left(\mathrm{m}_{\mathrm{a}}\right)\right)$ utilizou-se o valor de desvio padrão de 0,00005g.

No laboratório de Análise por Ativação Neutrônica, do Centro do Reator de Pesquisas (LAN-CRPq), IPEN/CNEN/SP, é feito gráfico de controle para padronização da balança pelos usuários. Neste trabalho foi utilizado o valor do desvio padrão calculado para o período 08/2003 a 12/2005, como uma contribuição da repetitividade na incerteza padrão associada à massa $\left(\mathbf{m}_{\mathbf{a}}\right)$ (Moreira e col., 2003). O desvio padrão encontrado foi de:

$$
\mu_{\mathrm{x} 3}=0,0002 \mathrm{~g}
$$


Finalmente, as componentes de incerteza da medição de massa (a repetitividade e a linearidade) foram combinadas para fornecer a incerteza padrão combinada $\left(\mu_{c}\left(m_{a}\right)\right)$ da massa da amostra do material biológico utilizado. A repetitividade foi levada em consideração apenas uma vez já que o desvio padrão das diferenças entre a tara e o peso bruto foi determinando diretamente. A contribuição da linearidade foi computada duas vezes, uma para a tara e outra para o peso bruto. A incerteza padrão combinada para a pesagem é apresentada na Equação 8:

$$
\begin{aligned}
& \mu_{c(\text { ma })}={\sqrt{2 *\left[u_{x 1}\right]^{2}+u_{x 2}{ }^{2}+u_{x 3}}}^{2} \quad \text { Equação } 8 \\
& \mu_{c(m a)}=\sqrt{2 *[0,000044]^{2}+0,00005^{2}+0,0002^{2}}
\end{aligned}
$$

$$
\mu_{\mathrm{c}(\mathrm{ma})}=0,0002 \mathrm{~g}
$$

\section{b) Incerteza associada ao Volume $\left(V_{f}\right)$ :}

Após a digestão, a solução amostra é transferida para um tubo de Teflon da Savilex de $50 \mathrm{~mL}$ $\left(\mathrm{V}_{\mathrm{f}}\right)$ no caso de análise de peixes e dietas e 18,2 $\mathrm{mL}\left(\mathrm{V}_{\mathrm{f}}\right)$ no caso de análise de cabelo, sendo o volume completado com água Milli-Q. Neste procedimento, estão inseridas três fontes de incertezas, que são as principais influências sofridas pelo volume: calibração, repetitividade e o efeito da temperatura (EURACHEM/CITAC GUIDE, 2002). A contribuição da calibração deve ser fornecida pelo fabricante, sendo uma incerteza do tipo B. Neste trabalho considerou-se para a incerteza associada ao volume a repetitividade e o efeito da temperatura, visto os tubos de Teflon utlizados não possuírem valor de calibração.

Utilizando-se a densidade $(\mathrm{d}=\mathrm{m} / \mathrm{v})$ da água a $18^{0} \mathrm{C}(0,998632)$, obtém-se o volume médio da

medida de dez tubos $(\bar{v})$, para cada valor calibrado. Assim, a incerteza padrão combinada ao volume $\left(\mu_{\mathrm{v}}\right)$ é o desvio padrão das medidas:

- $\left.\quad\left(\mu_{\mathrm{v} 3 \mathrm{a}}\right) 50 \mathrm{~mL}\right)=50,2677 \pm 0,0648 \mathrm{~mL} \quad \mu\left(\mathrm{Vcal}_{3 \mathrm{a}}\right)=0,0648 \mathrm{~mL}$

- $\left.\left(\mu_{\mathrm{v} 3 \mathrm{~b}}\right) 18,2 \mathrm{~mL}\right)=18,6274 \pm 0,0704 \mathrm{~mL} \boldsymbol{\mu}\left(\mathrm{Vcal}_{3 \mathrm{~b}}\right)=\mathbf{0 , 0 7 0 4} \mathrm{mL}$

A temperatura no laboratório varia numa faixa de $\pm 4^{\circ} \mathrm{C}$. A incerteza decorrente desse efeito pode ser estimada a partir da variação da temperatura e do coeficiente de expansão do volume. $\mathrm{O}$ 
coeficiente de expansão do volume para água é $2,1 \times 10^{-4}{ }^{\circ} \mathrm{C}$, o que produz uma variação de volume $\mathrm{de} \pm\left(50 \times 4 \times 2,1 \times 10^{-4}\right)= \pm 0,042 \mathrm{e}\left(18,2 \times 4 \times 2,1 \times 10^{-4}\right)= \pm 0,015$ (EURACHEM/CITAC GUIDE, 2002).

Trata-se de uma estimativa de incerteza do Tipo B e pode-se adotar uma distribuição de probabilidade do tipo retangular para a incerteza $\left(u\left(v_{t}\right)\right)$ associada a essa grandeza:

$$
u\left(v_{t 50 m L}\right)=\frac{0,042}{\sqrt{3}}=0,024 m L \quad u\left(v_{t 18,2 m L}\right)=\frac{0,015}{\sqrt{3}}=0,009 m L
$$

A incerteza padrão combinada do volume final é $\left(\mu_{\mathrm{c}}\left(\mathrm{V}_{\mathrm{f}}\right)\right)$ dada pela Equação 9:

$$
\begin{aligned}
& u_{c}\left(V_{f}\right)=\sqrt{u\left(V_{R}\right)^{2}+u\left(v_{t}\right)^{2}} \quad \text { Equação } 9 \\
& \mu_{c(V f 50 m L)}=\sqrt{0,024^{2}+0,0648^{2}}=\mathbf{0 , 0 6 9 1 ~} \mathbf{~ m L} \\
& \mu_{c(V f 18,2 m L)}=\sqrt{0,009^{2}+0,0704^{2}}=\mathbf{0 , 0 7 0 9} \mathbf{~ m L}
\end{aligned}
$$

\section{c) Incerteza associada à curva de calibração $\mu\left(\mathbf{C}_{0}\right)$ :}

\section{Human Hair Spiked (IAEA 085)}

O método de calibração externo utilizado em AAS requer a medição de um conjunto de soluções padrões com concentração conhecida do analito de interesse. Assim, na estimativa da incerteza associada à curva analítica foram consideradas a equação da curva (Equação 10) e os valores de calibração obtidos para cada solução com concentração diferentes. Foram preparadas 5 soluções com concentrações de: $88,02 \mathrm{ng} \mathrm{mL}^{-1}$; 16,05 ng mL ${ }^{-1}, 32,10 \mathrm{ng} \mathrm{mL}^{-1}, 64,20 \mathrm{ng} \mathrm{mL}^{-1}$ e $128,41 \mathrm{ng} \mathrm{mL} \mathrm{mL}^{-1}$ e estas soluções foram obtidas a partir da diluição de uma solução estoque (2) de concentração 1168,52 $\mathrm{ng} \mathrm{mL}^{-1}$. As pipetas utilizadas foram das marcas Eppendorf (AA-PIP-18) cujo intervalo é de 10-100 $\mu \mathrm{L}$ e Hamilton (AA-PIP-15) cujo intervalo é de 100 a $1000 \mu \mathrm{L}$. 
O procedimento de ajuste linear dos mínimos quadrados utilizado na curva de calibração do equipamento de AAS resulta que, segundo o guia da EURACHEM/CITAC GUIDE (2002), as incertezas dos valores das abcissas são considerados insignificantes perante os valores das ordenadas. Portanto, o cálculo das incertezas para a concentração do analito $\mu\left(\mathrm{C}_{0}\right)$, leva em conta somente as incertezas dos valores de absorbância (ordenada) e não as incertezas dos padrões de calibração, nem das diluições necessárias (abcissas).

As cinco soluções de calibração foram medidas três vezes cada. As absorbâncias estão apresentadas na Tabela 8 .

Tabela 8 . Absorbância obtida para as três determinações dos cinco padrões de $\mathrm{Hg}$ para o cálculo de $\mu\left(\mathrm{C}_{0}\right)$ para o material de referência Human Hair Spiked (IAEA 085)

\begin{tabular}{c|c|c|c|c|c}
\hline $\begin{array}{c}\text { Concentração } \\
\left(\mathrm{ng} \mathrm{mL}^{-1}\right)\end{array}$ & $\mathbf{8 , 0 2}$ & $\mathbf{1 6 , 0 5}$ & $\mathbf{3 2 , 1 0}$ & $\mathbf{6 4 , 2 0}$ & $\mathbf{1 2 8 , 4 1}$ \\
\hline \multirow{2}{*}{$\frac{\pi}{0}$} \\
$\substack{\frac{\pi}{\pi} \\
\frac{0}{0} \\
\frac{0}{4}}$ & 0,0693 & 0,1194 & 0,2179 & 0,3692 & 0,7761 \\
\cline { 2 - 6 } & 0,0689 & 0,1121 & 0,2152 & 0,3689 & 0,7733 \\
\cline { 2 - 6 } & 0,0676 & 0,1172 & 0,2174 & 0,3671 & 0,7731 \\
\hline
\end{tabular}

A curva analítica é dada pela Equação 10:

$$
A_{i}=c_{i}^{*} B_{2}+B_{1} \quad \text { Equação } 10
$$

Onde:

* $\mathrm{A}_{\mathrm{i}}$ : medida de absorbância da solução padrão;

* $\mathrm{B}_{1}$ : coeficiente linear da curva;

* $\mathrm{B}_{2}$ : coeficiente angular da curva;

* $c_{\mathrm{i}}$ : concentração da solução padrão;

* i: índice do número da medida dos padrões de calibração. 
O ajuste linear dos mínimos quadrados da curva analítica do procedimento proposto resultou na Equação 11:

$$
A=0,0058 x-0,0202
$$

Equação 11

com coeficiente de correlação $\mathrm{R}=0,9975$

A incerteza associada à concentração de $\mathrm{Hg}$ obtida para uma amostra $\left(\mathrm{C}_{0}\right)$ pela curva de calibração é calculada pela incerteza $\mu\left(\mathrm{C}_{0}\right)$ associada com o ajuste de mínimos quadrados de um conjunto de $\mathrm{n}$ pares de valores $\left(\mathrm{x}_{\mathrm{i}}, \mathrm{y}_{\mathrm{i}}\right)$. Existem quatro fontes de incerteza que devem ser levadas em consideração na composição da incerteza $\mu\left(\mathrm{C}_{0}\right)$ do resultado analítico $\left(\mathrm{C}_{0}=\right.$ concentração observada) (EURACHEM/CITAC GUIDE, 2002):

- Variações aleatórias nas medidas de "A" afetando tanto a medida de calibração ( $\left.\mathrm{y}_{\mathrm{i}}\right)$ como a determinação.

- Efeitos aleatórios que resultam em erros nos valores $\left(\mathrm{x}_{\mathrm{i}}\right)$ atribuídos aos padrões.

- Erros desconhecidos e constantes que podem afetar os valores de $\mathrm{x}_{\mathrm{i}}$ e $\mathrm{y}_{\mathrm{i}}$, como por exemplo, quando os valores $\mathrm{x}_{\mathrm{i}}$ são obtidos através de diluições de uma solução estoque.

- Não linearidade do método.

De todas essas, somente a primeira é significante na prática normal e portanto, considerada no cálculo da incerteza do resultado (EUROCHEM/CITAC, 2002). Para os dados da calibração, a equação final utilizada para a estimativa da incerteza associada $\mu\left(\mathrm{C}_{0}\right)$ é dada pela equação do desvio padrão residual (s), isto é, a variação residual para i-ésimo ponto (índice para o número do padrão de calibração):

Onde:

$$
\mu\left(C_{0}\right)=\frac{s}{b} \sqrt{\frac{1}{p}+\frac{1}{n}+\frac{\left(c_{0}-\bar{c}\right)^{2}}{S_{x x}}} \quad \text { Equação } 12
$$

* s : é o desvio padrão residual;

* b: é o coeficiente angular da reta da regressão;

* p: número de repetições para determinar $\mathrm{c}_{0}$;

* $\mathrm{c}_{0}$ : concentração do analito obtida para a amostra;

* $\overline{\boldsymbol{C}}$ : medida das concentrações dos padrões de calibração;

* $\mathrm{S}_{\mathrm{xx}}$ : somatória dos desvios padrões residuais. 
O valor do desvio padrão residual (s) é dado pela Equação 13:

$$
S=\sqrt{\frac{\sum_{j=1}^{n}\left[A_{j}-\left(B_{1}+B_{2} c_{j}\right)\right]^{2}}{n-2}} \quad \text { Equação } 13
$$

Onde:

j = índice do número da medida para se obter a curva de calibração.

O valor do somatório $S_{\mathrm{xx}}$ é dado pela Equação 14:

$$
S_{x x}=\sqrt{\sum_{j=1}^{n}\left(c_{j}-\bar{c}\right)^{2}} \quad \text { Equação } 14
$$

Utilizando a Equação 13, o valor do desvio padrão residual encontrado para as análises de Hg total realizadas foi de:

$$
s=0,045546433
$$

O valor de $S_{x x}$ foi calculado utilizado-se a Equação 14 foi de:

$$
S_{\mathrm{xx}}=31988,05
$$

Considerando-se que o valor obtido experimentalmente para a solução preparada com o material certificado utilizado na determinação de $\mathrm{Hg}$ total em cabelo foi de:

- Human Hair Spiked (IAEA 085) - $\mathrm{C}_{0}=127 \mathrm{ng} \mathrm{mL}^{-1}$

Temos, finalmente, o valor da incerteza associada à curva de calibração $\boldsymbol{\mu}\left(\mathbf{C}_{\mathbf{0}}\right)$ que foi de:

- Human Hair Spiked (IAEA 085) - $\left(\mu \mathrm{C}_{0}\right)=7,069 \mathrm{ng} \mathrm{mL}^{-1}$ 


\section{$R_{i 085}=102,54$ Dogfish muscle (DORM-1 NRCC)}

O método de calibração externo utilizado em AAS requer a medição de um conjunto de soluções padrões com concentração conhecida do analito de interesse. Assim, na estimativa da incerteza associada à curva analítica foram consideradas a equação da curva (Equação 10) e os valores de calibração obtidos para cada solução com concentração diferentes. Foram preparadas 5 soluções com concentrações de: $2,51 \mathrm{ng} \mathrm{mL}^{-1} ; 5,02 \mathrm{ng} \mathrm{mL}^{-1} ; 10,04 \mathrm{ng} \mathrm{mL}^{-1}, 20,08 \mathrm{ng} \mathrm{mL}^{-1}$ e 25,10 ng $\mathrm{mL}^{-1}$. Estas soluções foram obtidas a partir da diluição de uma solução estoque (2) de concentração 1.255,04 $\mathrm{mL}^{-1}$. As pipetas utilizadas foram eppendorf (AA-PIP-18) cujo intervalo é de 10-100 $\mu \mathrm{L}$ e Hamilton (AA-PIP-15) cujo intervalo é de 100 a $1000 \mu \mathrm{L}$.

As cinco soluções de calibração foram medidas três vezes cada. As absorbâncias estão apresentadas na Tabela 9.

Tabela 9 . Absorbância obtida para as três determinações dos cinco padrões de $\mathrm{Hg}$ para o cálculo de $\mu\left(\mathrm{C}_{0}\right)$ para o material de referência Dogfish muscle (DORM-1 NRCC)

\begin{tabular}{|c|c|c|c|c|c|}
\hline $\begin{array}{c}\text { Concentração } \\
\left(\mathrm{ng} \mathrm{mL}^{-1}\right)\end{array}$ & 2,51 & 5,02 & 10,04 & 20,08 & 25,10 \\
\hline \multirow{3}{*}{$\begin{array}{l}\frac{\pi}{0} \\
\frac{\pi}{\pi} \\
\frac{0}{2} \\
\frac{0}{0} \\
\frac{0}{4}\end{array}$} & 0,0217 & 0,0440 & 0,0894 & 0,1757 & 0,2208 \\
\hline & 0,0218 & 0,0437 & 0,0890 & 0,1750 & 0,2179 \\
\hline & 0,0220 & 0,0440 & 0,0890 & 0,1742 & 0,2185 \\
\hline
\end{tabular}

Uma vez que a curva analítica é dada pela Equação 10, o ajuste linear dos mínimos quadrados da curva analítica do procedimento proposto resultou na Equação 15:

$$
A=0,0088 x-0,0002 \quad \text { Equação } 15
$$

com coeficiente de correlação $\mathrm{R}=0,9997$.

Para os dados da calibração, a Equação 10 foi novamente utilizada para a estimativa da incerteza associada $\mu\left(\mathrm{C}_{0}\right)$ para este material de referência. 
Utilizando a Equação 13, o valor do desvio padrão residual encontrado para as análises de $\mathrm{Hg}$ total neste material de referência foi de:

$$
S=0,001621109
$$

$\mathrm{O}$ valor de $\mathrm{S}_{\mathrm{xx}}$ foi calculado utilizado-se a Equação 14 foi de:

$$
S_{\mathrm{Xx}}=1134,21
$$

Considerando-se que o valor obtido experimentalmente para a solução preparada com o material certificado utilizado na determinação de $\mathrm{Hg}$ total em peixes e dietas foi de:

- Dogfish muscle (DORM-1 NRCC) - $\mathrm{C}_{0}=7,86 \mathrm{ng} \mathrm{mL}^{-1}$

Temos, finalmente, o valor da incerteza associada à curva de calibração $\mu_{(\mathrm{C} 0)}$ para este material de referência que foi de:

- Dogfish muscle (DORM-1 NRCC) - $\left(\mu \mathrm{C}_{0}\right)=0,1192 \mathrm{ng} \mathrm{mL}^{-1}$

\section{d) Incerteza associada à taxa de recuperação $\left(\mathbf{R}_{\mathbf{i}}\right)$ :}

O resultado do estudo de recuperação de analito obtido pela análise dos materiais de referência indicou uma recuperação percentual conforme segue:

- Dogfish muscle (DORM-1 NRCC) - 99,25\% com desvio padrão relativo (RSD) de 7,0\%.

- Human Hair Spiked (IAEA 085) - 102,54\% com desvio padrão relativo (RSD) de 3,3 \%.

Portanto, a taxa de recuperação foi de:

$$
\begin{aligned}
& R_{\text {iDORM } 1}=\frac{99,25}{100}=0,9925 \\
& R_{i 085}=\frac{102,54}{100}=1,0254
\end{aligned}
$$


Nos dois casos, a taxa de recuperação foi muito próxima de 1, não havendo a necessidade de correção no valor final.

Deste modo, a incerteza padrão associada a esta grandeza pode ser considerada como:

$$
\begin{aligned}
& u\left(\left(_{R_{i} \text { DORM } 1}\right)=\frac{R S D}{100}=0,070\right. \\
& u\left(\left(_{R_{i} 085}\right)=\frac{R S D}{100}=0,033\right.
\end{aligned}
$$

\subsubsection{Cálculo da incerteza combinada para mercúrio total}

Nas Tabelas 10 e 11 estão resumidos os valores obtidos para as variáveis $\mathrm{C}_{0}, \mathrm{~m}_{\mathrm{a}}, \mathrm{V}_{\mathrm{f}} \mathrm{e}$ $\mathrm{R}_{\mathrm{i}}$, para os dois materiais de referência com suas incertezas padrões e incertezas padrões relativas $(\mu /$ valor obtido).

Tabela 10 . Valores das variáveis $\left(\mathrm{C}_{0}, \mathrm{~m}_{\mathrm{a}}, \mathrm{V}_{\mathrm{f}}\right.$ e $\left.\mathrm{R}_{\mathrm{i}}\right)$, suas incertezas padrões e incertezas padrões relativas para o Material de Referência Dogfish muscle (DORM-1 NRCC) ${ }^{\mathrm{a}}$

\begin{tabular}{c|l|c|c|c}
\hline Variável & \multicolumn{1}{|c|}{ Descrição } & Valor & $\begin{array}{c}\text { Incerteza } \\
\text { Padrão }(\boldsymbol{\mu})\end{array}$ & $\begin{array}{c}\text { Incerteza Padrão } \\
\text { Relativa }(\boldsymbol{\mu} / \mathbf{v a l o r})\end{array}$ \\
\hline $\mathbf{m}_{\mathbf{a}}$ & Massa & 0,5 & $0,0002 \mathrm{~g}$ & 0,0004 \\
$\mathbf{V}_{\mathbf{f}}$ & Volume & 50 & $0,0691 \mathrm{~mL}$ & 0,0013 \\
$\mathbf{C}_{\mathbf{0}}$ & Curva de Calibração & 7,86 & $0,1192 \mathrm{ng} \mathrm{mL}^{-1}$ & 0,0152 \\
$\mathbf{R}_{\mathbf{i}}$ & Taxa de recuperação & 0,9925 & 0,07 & 0,07 \\
\hline
\end{tabular}

a Este Material de Referência foi utilizado na análise dos peixes, portanto, neste caso, adotou-se o valor de 0,5g para a avaliação da contribuição da massa e o valor de $50 \mathrm{~mL}$ para a avaliação da contribuição do volume, no cálculo da incerteza final. 
Substituindo-se as variáveis da Equação 6 pelos respectivos valores apresentados na Tabela 10, obtém-se para o material de referência Dogfish muscle (DORM-1 NRCC):

$$
\mathrm{C}_{\mathrm{Hg}}=0,792 \mathrm{mg} \mathrm{kg}^{-1}
$$

Para calcular a incerteza padrão combinada, as incertezas padrão relativa de cada componente foram consideradas, de acordo com a Equação 16:

$$
\frac{\mu_{c}\left(C_{a}\right)}{C_{a}}=\sqrt{\left(\frac{\mu\left(C_{0}\right)}{C_{0}}\right)^{2}+\left(\frac{\mu\left(m_{a}\right)}{m_{a}}\right)^{2}+\left(\frac{\mu\left(V_{f}\right)}{V_{f}}\right)^{2}+\left(\frac{\mu\left(R_{i}\right)}{R_{i}}\right)^{2}} \quad \text { Equação } 16
$$

e substituindo nesta equação os valores da incerteza padrão relativa de cada componente, apresentados na Tabela 10 e o valor de $C_{\mathrm{Hg}}$ obtido pela Equação 6, temos:

$$
\mu_{\mathrm{c}}\left(C_{\mathrm{Hg}}\right)=0,057 \mathrm{mg} \mathrm{kg}^{-1}
$$

Tabela 11 . Valores das variáveis $\left(\mathrm{C}_{0}, \mathrm{~m}_{\mathrm{a}}, \mathrm{V}_{\mathrm{f}}\right.$ e $\left.\mathrm{R}_{\mathrm{i}}\right)$, suas incertezas padrões e incertezas padrões relativas para o Material de Referência Human Hair Spiked (IAEA 085) ${ }^{\mathrm{a}}$

\begin{tabular}{c|l|c|c|c}
\hline Variável & \multicolumn{1}{|c|}{ Descrição } & Valor & $\begin{array}{c}\text { Incerteza } \\
\text { Padrão (u) }\end{array}$ & $\begin{array}{c}\text { Incerteza Padrão } \\
\text { Relativa (u/valor) }\end{array}$ \\
\hline $\mathbf{m}_{\mathbf{a}}$ & Massa & 0,1 & 0,0002 & 0,002 \\
\hline $\mathbf{V}_{\mathbf{f}}$ & Volume & 18,2 & $0,0744 \mathrm{~mL}$ & 0,004 \\
\hline $\mathbf{C}_{\mathbf{0}}$ & Curva de Calibração & 127 & $7,0688 \mathrm{ng} \mathrm{mL}-1$ & 0,056 \\
\hline $\mathbf{R}_{\mathbf{i}}$ & Taxa de recuperação & 1,0254 & 0,033 & 0,032 \\
\hline
\end{tabular}

a Este Material de Referência foi utilizado na análise dos cabelos, portanto, neste caso, adotou-se o valor de 0,1g para a avaliação da contribuição da massa e o valor de 18,2 mL para a avaliação da contribuição do volume, no cálculo da incerteza final.

Substituindo as variáveis da Equação 6 pelos respectivos valores apresentados na Tabela 11, obtém-se para o material de referência Human Hair Spiked (IAEA 085):

$$
\mathrm{C}_{\mathrm{Hg}}=22,54 \mathrm{mg} \mathrm{kg}^{-1}
$$


Para calcular a incerteza padrão combinada, as incertezas padrão de cada componente foram consideradas, de acordo com a Equação 16 e substituindo nesta equação os valores da incerteza padrão relativa de cada componente, apresentados na Tabela 11 e o valor de $\mathrm{C}_{\mathrm{Hg}}$ obtido pela Equação 6, temos:

$$
\mu_{\mathrm{c}}\left(\mathrm{C}_{\mathrm{Hg}}\right)=1,45 \mathrm{mg} \mathrm{kg}^{-1}
$$

\subsubsection{Cálculo da incerteza expandida para mercúrio total}

A incerteza combinada expressa a incerteza do resultado de uma medição. No entanto, em algumas situações, é necessária a estimativa da incerteza em um intervalo definido. Com este intervalo, espera-se abranger uma grande parcela da distribuição de valores que deveriam ser atribuídos ao mensurando em uma distribuição normal.

Esta incerteza é estimada por meio da incerteza expandida (U). Esta é obtida por meio da multiplicação da incerteza combinada por um fator de abrangência k. Para um nível de confiança de 95\%, o valor de k considerado é 2.

Assim, para os cálculos aqui efetuados, o valor da incerteza expandida é:

$$
\begin{gathered}
\mathrm{UD}_{\mathrm{DRM}-1}=\mathbf{0 , 1 1 4} \mathbf{~ m g ~ k g ~}^{-1} \\
\mathrm{U}_{085}=\mathbf{2 , 9} \mathbf{~ m ~} \mathbf{~ k g ~}^{-1}
\end{gathered}
$$

Deste modo, finalizando o resultado obtido para a concentração de $\mathrm{Hg}$ nos materiais certificados (DORM-1 NRCC e IAEA 085) acompanhado da incerteza expandida do procedimento foi de:

$$
\begin{aligned}
{\left[\mathrm{Hg} \text { total }_{\text {DORM-1 }}\right] } & =\mathbf{0 , 7 9 2} \pm \mathbf{0 , 1 1 4} \mathbf{~ m g ~ k g ~}^{-1} \\
{\left[\mathrm{Hg} \text { total }_{085}\right] } & =\mathbf{2 2 , 5 4} \pm \mathbf{2 , 9} \mathbf{~ m g ~ k g ~}^{-1}
\end{aligned}
$$

Analisando-se os valores obtidos para a Incerteza Padrão $(\mu)$, nas Tabelas 10 e 11, concluímos que a maior influência na incerteza global do procedimento foi proveniente da curva analítica, seguida pela recuperação do analito, ambas relacionadas com a resposta obtida no equipamento. 


\section{Metilmercúrio}

\section{a) Incerteza associada à massa $\left(\mathbf{m}_{\mathbf{a}}\right)$ :}

A massa da amostra foi obtida por meio da diferença entre a massa do tubo utilizado na pesagem e a massa total. As amostras foram pesadas na balança semi-analítica (resolução de 0,0001g) da marca Ohaus, modelo AR2140 Adventurer (AA-BAL-07).

As medidas de massa estão sujeitas à variabilidade decorrente de pesagens sucessivas (repetividade) e à incerteza de calibração da balança utilizada. A calibração possui duas fontes de incerteza: a linearidade e a sensibilidade da balança, sendo que o efeito desta última pode ser ignorado visto que as medidas foram realizadas na mesma balança em um curto período de tempo.

A balança possui certificado de calibração $n^{\circ}$ R041 74601, no qual a incerteza expandida da balança é fornecida como sendo de 0,0001 (95\% de confiança) para um peso padrão de $0,5 \mathrm{~g}$. Para se obter a incerteza padrão $\left(\mu_{\mathrm{x} 1}\right)$ da massa, avaliando-se o componente do Tipo $\mathrm{B}$, obtidos a partir de documentação, dividiu-se esse valor por 2,28 (k, valor de abrangência), obtendo-se:

\section{$\mu_{\mathrm{x} 1}=0,000044 \mathrm{~g}$}

Uma outra contribuição da repetitividade na incerteza associada à massa (ma) foi determinada por meio de dez pesagens sucessivas de um peso padrão de verificação, de massa próxima ao valor da massa da amostra $(0,100 \mathrm{~g}$ e $0,500 \mathrm{~g})$, obtida pela pesagem dos pesos com massa próxima ao valor da massa utilizada para a amostra. Utilizou-se a Equação 7 no cálculo desta incerteza, obtendo-se:

$$
\begin{aligned}
\mu \mathrm{x}_{2 \mathrm{a}} & =0,00004 \mathrm{~g} \\
\mu \mathrm{x}_{2 \mathrm{~b}} & =0,00005 \mathrm{~g}
\end{aligned}
$$

Foi encontrado o mesmo valor para a incerteza associada à massa $\left(\mu_{\mathrm{c}}\left(\mathrm{m}_{\mathrm{a}}\right)\right)$, tanto para a massa de $0,1 \mathrm{~g}$, quanto para a massa de $0,5 \mathrm{~g}$. Portanto, optou-se por nomear esta incerteza de $\boldsymbol{\mu} \mathbf{X}_{2}$ que representará neste trabalho, as duas massas anteriormente citadas e no cálculo final $\left(\mu_{\mathrm{c}}\left(\mathrm{m}_{\mathrm{a}}\right)\right)$ utilizou-se o valor de desvio padrão de $0,00005 \mathrm{~g}$.

No laboratório de Análise por Ativação Neutrônica, do centro do Reator de Pesquisas (LAN-CRPq), IPEN/CNEN/SP, é feito gráfico de controle para padronização da balança pelos usuários. Neste trabalho foi utilizado o valor do desvio padrão calculado para o período 08/2003 a 
12/2005, como uma contribuição da repetitividade na incerteza associada à massa $\left(\mathbf{m}_{\mathbf{a}}\right)$ (Moreira e col., 2003). O desvio padrão encontrado foi de:

\section{$\mu_{\mathrm{x} 3}=0,0002 \mathrm{~g}$}

Foi encontrado o mesmo valor para a incerteza associada à massa $\left(\mu_{c}\left(m_{a}\right)\right)$, tanto para a massa de $0,1 \mathrm{~g}$, quanto para a massa de $0,5 \mathrm{~g}$. Portanto, optou-se por nomear esta incerteza de $\boldsymbol{\mu} \mathbf{x}_{\mathbf{2}}$ que representará neste trabalho, as duas massas anteriormente citadas e no cálculo final $\left(\mu_{\mathrm{c}}\left(\mathrm{m}_{\mathrm{a}}\right)\right)$ utilizou-se o valor de desvio padrão de $0,00005 \mathrm{~g}$.

Finalmente, as componentes de incerteza da medição de massa, a repetitividade e a linearidade, foram combinadas para fornecer a incerteza padrão combinada $\left(\mu_{c}\left(m_{a}\right)\right)$ da massa da amostra do material biológico utilizado. A repetitividade foi levada em consideração apenas uma vez, já que o desvio padrão das diferenças entre a tara e o peso bruto foi determinando diretamente. A contribuição da linearidade foi computada duas vezes, uma para a tara e outra para o peso bruto. A incerteza padrão combinada para a pesagem é apresentada na Equação 8:

$$
\mu_{\mathrm{c}(\mathrm{ma})}=0,0002 \mathrm{~g}
$$

\section{b) Incerteza associada ao Volume $\left(V_{f}\right)$ :}

Para a determinação do $\mathrm{MeHg}$, deverá também ser computada na incerteza padrão combinada do volume, a incerteza da calibração dos dois tubos de Teflon utilizados, $50 \mathrm{~mL}$ e $10 \mathrm{~mL}$.

Utilizando-se a densidade $(\mathrm{d}=\mathrm{m} / \mathrm{v})$ da água a $18^{0} \mathrm{C}(0,998632)$, obtém-se o volume médio da medida de dez tubos $(\bar{v})$, para cada valor calibrado. Assim, a incerteza padrão combinada ao votume $\left(\mu_{\mathrm{v}}\right)$ é o desvio padrão das medidas:

- $\left.\quad\left(\mu_{\mathrm{v} 3 \mathrm{a}}\right) 50 \mathrm{~mL}\right)=50,2677 \pm 0,0648 \mathrm{~mL}$

$$
\begin{aligned}
& \mu\left(\operatorname{Vcal}_{50 \mathrm{~mL}}\right)=0,0648 \mathrm{~mL} \\
& \mu\left(\operatorname{Vcal}_{10 \mathrm{~mL}}\right)=0,0975 \mathrm{~mL}
\end{aligned}
$$$$
\text { - } \left.\left(\mu_{\mathrm{v} 3 \mathrm{~b}}\right) 10 \mathrm{~mL}\right)=10,1365 \pm 0,0975 \mathrm{~mL}
$$

A temperatura no laboratório varia numa faixa de $\pm 4^{\circ} \mathrm{C}$. A incerteza decorrente desse efeito pode ser estimada a partir da variação da temperatura e do coeficiente de expansão do volume. O coeficiente de expansão do volume para água é $2,1 \times 10^{-4}{ }^{\circ} \mathrm{C}$, o que produz uma variação de volume 
de $\pm\left(50 \times 4 \times 2,1 \times 10^{-4}\right)= \pm 0,042$ e $\pm\left(10 \times 4 \times 2,1 \times 10^{-4}\right)= \pm 0,084$. Trata-se de uma estimativa de incerteza do Tipo B e pode-se adotar uma distribuição de probabilidade do tipo retangular para a incerteza $\left(u\left(v_{t}\right)\right)$ associada a essa grandeza:

$$
u\left(v_{t}\right)=\frac{0,042}{\sqrt{3}}=0,024 m L \quad u\left(v_{t}\right)=\frac{0,084}{\sqrt{3}}=0,0027 m L
$$

A incerteza padrão combinada do volume final é $\left(\mu_{\mathrm{c}}\left(\mathrm{V}_{\mathrm{f}}\right)\right)$ dada pela Equação 9:

$$
\mu_{c}=0,1195 \mathrm{~mL}
$$

\section{c) Incerteza associada à curva de calibração $\mu\left(\mathbf{C}_{0}\right)$ :}

O método de calibração externo utilizado em um equipamento de AAS requer a medição de um conjunto de soluções padrões com concentração conhecida do analito de interesse. Assim, na estimativa da incerteza associada à curva analítica foram consideradas a equação da curva (Equação 10) e os valores de calibração obtidos para cada solução com concentração diferentes. Foram preparadas 5 soluções com concentrações de: $58,02 \mathrm{ng} \mathrm{mL}^{-1} ; 16,05 \mathrm{ng} \mathrm{mL}^{-1} ; 32,10 \mathrm{ng} \mathrm{mL}^{-1} ; 64,20$ $n g \mathrm{~mL}^{-1}$ e $128,41 \mathrm{ng} \mathrm{mL} \mathrm{mL}^{-1}$. Estas soluções foram obtidas a partir da diluição de uma solução estoque (2) de concentração 1.255,04 $\mathrm{ng} \mathrm{mL}^{-1}$. As pipetas utilizadas foram das marcas Eppendorf (AA-PIP18) cujo intervalo é de 10-100 $\mu \mathrm{L}$ e Hamilton (AA-PIP-15), cujo intervalo é de 100 a $1000 \mu \mathrm{L}$.

O procedimento de ajuste linear dos mínimos quadrados utilizado na curva de calibração do AAS resulta que, segundo o guia da (EURACHEM/CITAC GUIDE, 2002), as incertezas dos valores das abcissas considerados insignificantes perante os valores das ordenadas. Portanto, o cálculo das incertezas para a concentração do analito $\mu\left(\mathrm{C}_{0}\right)$ levam em conta somente as incertezas dos valores de absorbância (ordenada) e não as incertezas dos padrões de calibração, nem das diluições necessárias (abcissas).

As cinco soluções de calibração foram medidas três vezes cada. As absorbâncias estão apresentadas na Tabela 12 . 
Tabela 12 . Absorbância obtida para as três determinações dos cinco padrões de Hg para o cálculo de $\mu\left(\mathrm{C}_{0}\right)$ para o material de referência Human Hair Spiked (IAEA 085)

\begin{tabular}{|c|c|c|c|c|c|}
\hline $\begin{array}{l}\text { Concentração } \\
\qquad\left(n g \mathrm{~mL}^{-1}\right)\end{array}$ & 8,02 & 16,05 & 32,10 & 64,20 & 128,41 \\
\hline \multirow{3}{*}{$\begin{array}{l}\frac{\pi}{0} \\
\frac{0}{\pi} \\
\frac{0}{0} \\
\frac{0}{0} \\
0 \\
\frac{0}{\alpha}\end{array}$} & 0,0484 & 0,0934 & 0,1967 & 0,3491 & 0,7569 \\
\hline & 0,0478 & 0,0951 & 0,1945 & 0,3482 & 0,7553 \\
\hline & 0,0471 & 0,0963 & 0,199 & 0,3481 & 0,7541 \\
\hline
\end{tabular}

Uma vez que a curva analítica é dada pela Equação 10, o ajuste linear dos mínimos quadrados da curva analítica do procedimento proposto resultou na Equação 17:

\section{$A=0,0058 x-0,0009 \quad$ Equação 17}

com coeficiente de correlação $\mathrm{R}=0,9975$.

Para os dados da calibração, a Equação 10 foi novamnete utilizada para a estimativa da incerteza associada $\mu\left(\mathrm{C}_{0}\right)$ para este material de referência.

Utilizando a Equação 13, o valor do desvio padrão residual encontrado para as análises de $\mathrm{Hg}$ total neste material de referência foi de:

$$
S=0,013690033
$$

O valor de $S_{x x}$, foi calculado utilizado-se a Equação 14 foi de:

$$
S_{x x}=33077,02
$$

Considerando-se que o valor obtido experimentalmente para a solução preparada com o material certificado utilizado na determinação de $\mathrm{MeHg}$ em cabelos foi de: 
- Human Hair Spiked (IAEA 085) - $\mathrm{C}_{0}=46,15 \mathrm{ng} \mathrm{mL}^{-1}$

Temos, finalmente, o valor da incerteza associada à curva de calibração $\boldsymbol{\mu}\left(\mathbf{C}_{\mathbf{0}}\right)$ que foi de:

- Human Hair Spiked (IAEA 085) - $\left(\mu \mathrm{C}_{0}\right)=1,0253 \mathrm{ng} \mathrm{mL}^{-1}$

\section{d) Incerteza associada à taxa de recuperação $\left(\mathbf{R}_{\mathbf{i}}\right)$ :}

O resultado do estudo de recuperação de analito obtido pela análise dos materiais de referência, indicou uma recuperação percentual conforme segue:

- Human Hair Spiked (IAEA 085) - 94,76\% com desvio padrão relativo (RSD) de 1,3\%.

Portanto, a taxa de recuperação foi de:

$$
R_{i 085}=\frac{93,88}{100}=0,9388
$$

Nesse caso, a taxa de recuperação foi muito próxima de 1, não havendo a necessidade de correção no valor final.

Deste modo, a incerteza padrão associada a esta grandeza pode ser considerada como:

$$
\mu_{i\left(R_{i} 085\right)}=\frac{R S D}{100}=0,033
$$

\subsubsection{Cálculo da incerteza combinada para metilmercúrio}

Na Tabela 13 estão resumidos os valores obtidos para as variáveis $C_{0}, m_{a}, V_{f}$ e $R_{i}$, para os três materiais de referência com suas incertezas padrões e incertezas padrões relativas (u/valor obtido). 
Tabela 13 . Valores das variáveis $\left(\mathrm{C}_{0}, \mathrm{~m}_{\mathrm{a}}, \mathrm{V}_{\mathrm{f}}\right.$ e $\left.\mathrm{R}_{\mathrm{i}}\right)$, suas incertezas padrões e incertezas padrões relativas para o Material de Referência Human Hair Spiked (IAEA 085)

\begin{tabular}{c|l|c|c|c}
\hline Variável & \multicolumn{1}{|c|}{ Descrição } & Valor & $\begin{array}{c}\text { Incerteza } \\
\text { Padrão (u) }\end{array}$ & $\begin{array}{c}\text { Incerteza Padrão } \\
\text { Relativa (u/valor) }\end{array}$ \\
\hline $\mathbf{m}_{\mathbf{a}}$ & Massa & 0,1 & 0,0002 & 0,002 \\
$\mathbf{V}_{\mathbf{f}}$ & Volume* & 50 & 0,1195 & 0,002 \\
$\mathbf{C}_{\mathbf{0}}$ & Curva de Calibração & 46,15 & 1,0253 & 0,022 \\
$\mathbf{R}_{\mathbf{i}}$ & Taxa de recuperação & 1,0254 & 0,033 & 0,032 \\
\hline
\end{tabular}

\% Optou-se por apresentar somente o volume de $50 \mathrm{~mL}$ visto que o resultado final do cálculo da Incerteza Padrão Relativa (u/valor), para $\mathbf{V}_{\mathbf{f}}$, não apresentou diferença siginificativa quando somado os valores obtidos para as Incertezas Padrão (u) para os tubos de 50 e $10 \mathrm{~mL}$.

Substituindo as variáveis da Equação 6 pelos respectivos valores apresentados na Tabela 13, obtém-se:

$$
\mathrm{C}_{\mathrm{MeHg}}=22,45 \mathrm{mg} \mathrm{kg}^{-1}
$$

Para calcular a incerteza padrão combinada, as incertezas padrão de cada componente foram consideradas, de acordo com a Equação 16, apresentada anteriormente e substituindo-se nesta equação os valores da incerteza padrão relativa de cada componente, apresentados na Tabela 13 e o valor de $\mathrm{C}_{\mathrm{Hg}}$ obtido pela Equação 6, temos:

$$
\mu_{\mathrm{c}}\left(\mathrm{C}_{\mathrm{MeHg}}\right)=1,54 \mathrm{mg} \mathrm{kg}^{-1}
$$

\subsubsection{Cálculo da incerteza expandida para metilmercúrio}

A incerteza combinada expressa a incerteza do resultado de uma medição. No entanto, em algumas situações, é necessária a estimativa da incerteza em um intervalo definido. Com este intervalo, espera-se abranger uma grande parcela da distribuição de valores que deveriam ser atribuídos ao mensurando em uma distribuição normal. 
Esta incerteza é estimada por meio da incerteza expandida (U). Esta é obtida por meio da multiplicação da incerteza combinada por um fator de abrangência k. para um nível de confiança de 95\%, o valor de k considerado é 2 .

Assim, para os cálculos aqui efetuados, o valor da incerteza expandida é:

$$
\mathrm{U}_{\mathrm{MeHg}}=\mathbf{3 , 0 8} \mathbf{m g ~ k g}^{-1}
$$

Deste modo, finalizando o resultado obtido para a concentração de $\mathrm{Hg}$ no material certificado (IAEA 085) acompanhado da incerteza expandida do procedimento foi de:

$$
\left[\mathrm{MeHg} \text { total }_{085}\right]=\mathbf{2 2 , 4 5} \pm \mathbf{3 , 0 8} \mathbf{m g ~ k g}^{-1}
$$

Analisando-se os valores obtidos para a Incerteza Padrão (u), na Tabela 12, concluímos que a maior influência na incerteza global do procedimento também foi proveniente da curva analítica, seguida pela recuperação do analito, ambas relacionadas com a resposta obtida no equipamento.

\section{Considerações finais}

No presente estudo, o valor da incerteza expandida para ambas metodologias, $\mathrm{Hg}$ total e $\mathrm{MeHg}$, corresponde a aproximadamente a $14 \%$ da concentração final de $\mathrm{Hg}$ nos materiais certificados. Este valor é da mesma ordem de grandeza de um trabalho realizado no Laboratório de Caracterização Química (LCQ-CQMA) do IPEN-CNEN/SP, no qual o $\mathrm{Hg}$ foi determinado em amostras de cabelos de índios Wari, também pelo método FIA-CV-AAS, no qual a incerteza expandida calculada foi da ordem de $19 \%$ da concentração final de $\mathrm{Hg}$ no material certificado (Campos, 2001). Em outro estudo, também realizado no Laboratório de Caracterização Química (LCQ-CQMA) do IPEN-CNEN/SP, no qual o Hg foi determinado em amostras de solo, alimentos e vegetação rasteira do município de Cachoeira do Piriá, a incerteza expandida calculada foi da ordem de $20 \%$ da concentração final de Hg no material certificado (Lima, 2005).

Foi também da mesma ordem de grandeza o resultado de um outro trabalho por espectrometria de absorção atômica no exemplo: (A5: Determinação de liberação de cádmio em produtos cerâmicos por espectrometria de absorção atômica) do EURACHEM/CITAC GUIDE (2002). 
Seguindo este procedimento descrito, calculou-se as incertezas expandidas dos teores de $\mathrm{Hg}$ nas dietas, peixes e cabelos analisados, conforme tabelas anexas: Tabela 17 (anexo III), Tabela 19 (anexo IV), Tabela 20 (anexo V), Tabela 22 (anexo VI), Tabela 23 (anexo VII), Tabela 25 (anexo VIII), Tabela 27 (anexo IX), Tabela 28 (anexo X), Tabela 29 (anexo XI), Tabela 30 (anexo XII), Tabela 31 (anexo XIII), Tabela 32 (anexo XIV), Tabela 33 (anexo XV), Tabela 34 (anexo XVI), Tabela 35 (anexo XVII), Tabela 36 (XVIII), Tabela 43 (anexo XX). 


\section{CAPÍTULO 7}

\section{Resultados e Discussões}

Devido à grande quantidade de resultados experimentais e diferentes elementos analisados, obtidos por meio da utilização de duas técnicas analíticas, optou-se pela apresentação dos resultados por técnica analítica e não por região. Apresentam-se a seguir, os resultados obtidos pela técnica de CV AAS para $\mathrm{Hg}$ total e $\mathrm{MeHg}$, nas respectivas matrizes e por último, os resultados obtidos pela técnica de AAN, nas análises das dietas (PNJ e outras comunidades) e dos peixes (Manaus).

Como um dos objetivos específicos deste trabalho era estabelecer e avaliar as metodologias para análise de $\mathrm{Hg}$ total em dietas, cabelo e peixe e MeHg em cabelo, pelo método CV AAS, optouse também por iniciar com a apresentação dos resultados obtidos na análise dos materiais de referência. Em seguida, avaliou-se o quadro da distribuição do $\mathrm{Hg}$ e $\mathrm{MeHg}$ nas comunidades do PNJ, bem como, em algumas comunidades Amazônicas e alguns bairrros da cidade de Manaus.

No item 7.2, serão apresentados os resultados dos elementos determinados pelo método de AAN para as amostras de dieta das comunidades do PNJ e algumas comunidades Amazônicas e peixe da cidade de Manaus.

\subsection{Resultados de Hg e MeHg pelo método de CV AAS}

\subsubsection{Resultados das análises dos materiais de referência biológicos por CV AAS}

\section{Mercúrio total - exatidão e precisão da metodologia}

Vários experimentos foram realizados para a verificação da digestão ideal para cada tipo de matriz analisada: dieta, cabelo ou peixe. Foram testados vários volumes de $\mathrm{K}_{2} \mathrm{Cr}_{2} \mathrm{O}_{7}$ para se obter a estabilidade adequada do $\mathrm{Hg}$ inorgânico, ficando estabelecido o volume de $250 \mu \mathrm{L}$ para amostras de cabelo, onde foram utilizados tubos de Teflon de $18,2 \mathrm{~mL}$ de capacidade e $500 \mu \mathrm{L}$ para dietas e peixe, onde foram usados tubos de Teflon de $50 \mathrm{~mL}$. 
A validação da metodologia para a determinação de $\mathrm{Hg}$ total em dietas e peixes neste trabalho, foi feita por meio da análise de materiais de referência com valores certificados, a saber: Fish Tissue (IAEA-407), Orchard Leaves (NIST SRM 1571), Typical Diet (NIST SRM 1548 ${ }^{\mathrm{a}}$ ) e Dogfish Muscle (DORM-1 NRCC). A validação da metodologia para a determinação de Hg total em cabelo foi feita por meio da análise de materiais de referência com valores certificados, a saber: Human Hair Spiked (IAEA 085) e Human Hair (IAEA, 086). Na Tabela 14, encontram-se os resultados obtidos na análise desses materiais de referência, bem como os valores certificados. Os resultados obtidos para a determinação do $\mathrm{Hg}$ total nos materiais de referência biológicos mostraram desvios padrões relativos de 1,4 a $25 \%$ e erros relativos de 0 a $5,2 \%$, verificando-se a precisão e exatidão respectivamente. Verifica-se por meio desses dados que, para os materiais analisados, os erros e os desvios relativos foram baixos, com exceção do material de referência Typical Diet devido ao baixo nível de concentração de $\mathrm{Hg}\left(5\left(\mu \mathrm{g} \mathrm{kg}{ }^{-1}\right)\right.$.

Tabela 14 . Resultados de $\mathrm{Hg}$ total $\left(\mu \mathrm{g} \mathrm{kg}{ }^{-1}\right)$ nos materiais de referência $(\mathrm{n}=7)$

\begin{tabular}{c|c|c|c|c}
\hline Material de Referência & $\begin{array}{c}\mathbf{H g}_{\text {total }}\left(\boldsymbol{\mu g} \mathbf{~ k g}^{-\mathbf{1}}\right) \\
(\text { média } \pm \mathbf{d . p .})\end{array}$ & $\begin{array}{c}\text { Valor Certificado } \\
\left(\mu \mathbf{~ k g}^{-\mathbf{1}}\right)\end{array}$ & $\begin{array}{c}\text { DPR } \\
(\%)\end{array}$ & $\begin{array}{c}\text { ER } \\
(\%)\end{array}$ \\
\hline DORM-1 NRCC (Dogfish Muscle) & $798 \pm 43$ & $798 \pm 74$ & 5,4 & 0 \\
IAEA-407 (Fish Tissue) & $220 \pm 3$ & $222 \pm 24$ & 1,4 & 0,9 \\
Orchard leaves (NIST SRM 1571) & $147 \pm 7$ & $155 \pm 15$ & 4,8 & 5,2 \\
Typical Diet (NIST SRM 1548a) & $4 \pm 1$ & $(5)$ & 25 & - \\
\hline IAEA-085 (Human Hair) (mg kg-1) & $22,97 \pm 0,60$ & $23,2(22,4-24,0)$ & 2,6 & 1,0 \\
\hline IAEA-086 (Human Hair) & $579 \pm 21$ & $573(534-612)$ & 3,6 & 1,0 \\
\hline
\end{tabular}

Durante a realização desse trabalho, foram feitas análises periódicas de materiais de referências certificados para a construção de gráficos de controle para a análise de Hg total (Figura 22), podendo-se assim, garantir que todas as etapas do procedimento analítico estavam sob controle estatístico. Analisando os gráficos de controle podemos verificar que os resultados foram bons para a determinação do $\mathrm{Hg}$ total nos materiais de referência e os valores não ultrapassaram os limites inferiores e superiores dos desvios padrões fornecidos para os materiais. 
Uma vez obtidas as melhores condições de análise para determinação de $\mathrm{Hg}$ total nas dietas e cabelos por CV AAS, conforme descrito no item 5.3.1.1. do capítulo 5, efetuaram-se as análises das amostras.
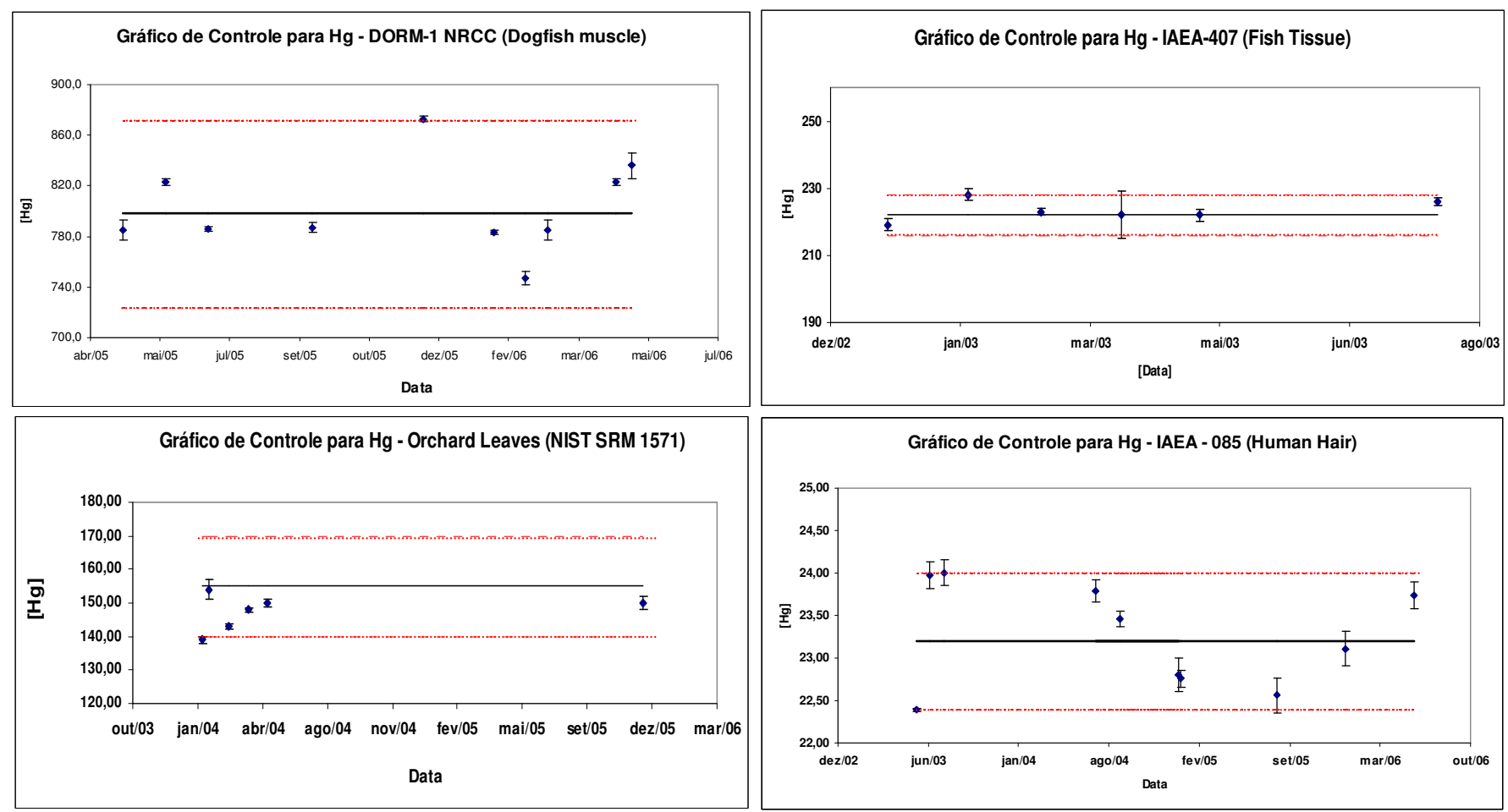

Figura 22. Gráficos de controle do procedimento proposto para análise de $\mathrm{Hg}$ total em materiais de referência.

Metilmercúrio - exatidão e precisão da metodologia

A validação da metodologia para a determinação de MeHg em cabelo neste trabalho, foi feita por meio da análise dos materiais de referência com valor certificado, a saber: Human Hair Spiked (IAEA 085) e Human Hair (IAEA 086). Na Tabela 15, encontram-se os resultados obtidos na análise desses materiais de referência, bem como o valor certificado. 
Os resultados obtidos para a determinação do $\mathrm{MeHg}$ nos materiais de referência apresentaram desvio padrão relativo de 2,2 a $6,2 \%$ e erro relativo de 0,4 a $1,5 \%$, verificando-se a precisão e exatidão do método, respectivamente.

Tabela 15 .Resultados obtidos para $\mathrm{MeHg}\left(\mathrm{mg} \mathrm{kg}^{-1}\right)$ nos materiais de referência IAEA-085 e 086 (Human Hair)

\begin{tabular}{|c|c|c|c|c|}
\hline Material de Referência & $\begin{array}{c}\operatorname{MeHg}\left(\mu \mathrm{kg}^{-1}\right) \\
(\text { média } \pm \text { d.p.) }\end{array}$ & $\begin{array}{c}\text { Valor Certificado } \\
\qquad\left(\mathrm{mg} \mathrm{kg}^{-1}\right)\end{array}$ & $\begin{array}{l}\text { DPR } \\
(\%)\end{array}$ & $\begin{array}{l}\text { ER } \\
(\%)\end{array}$ \\
\hline IAEA-085 (Human Hair) $(n=7)$ & $22,8 \pm 0,5$ & $22,9(21,9-23,9)$ & 2,2 & 0,4 \\
\hline IAEA-086 (Human Hair) $(n=3)$ & $254 \pm 16$ & $258(236-279)$ & 6,2 & 1,5 \\
\hline
\end{tabular}

Durante a realização desse trabalho, foram feitas análises periódicas do material de referência certificado para a construção de gráfico de controle para a análise de MeHg (Figura 23), podendo-se assim, avaliar as análises ao longo do tempo. Analisando o gráfico de controle podemos verificar que os resultados foram bons para a determinação do $\mathrm{MeHg}$ nos materiais de referência e os valores não ultrapassaram os limites inferiores e superiores dos desvios padrões fornecidos pelos materiais certificados.
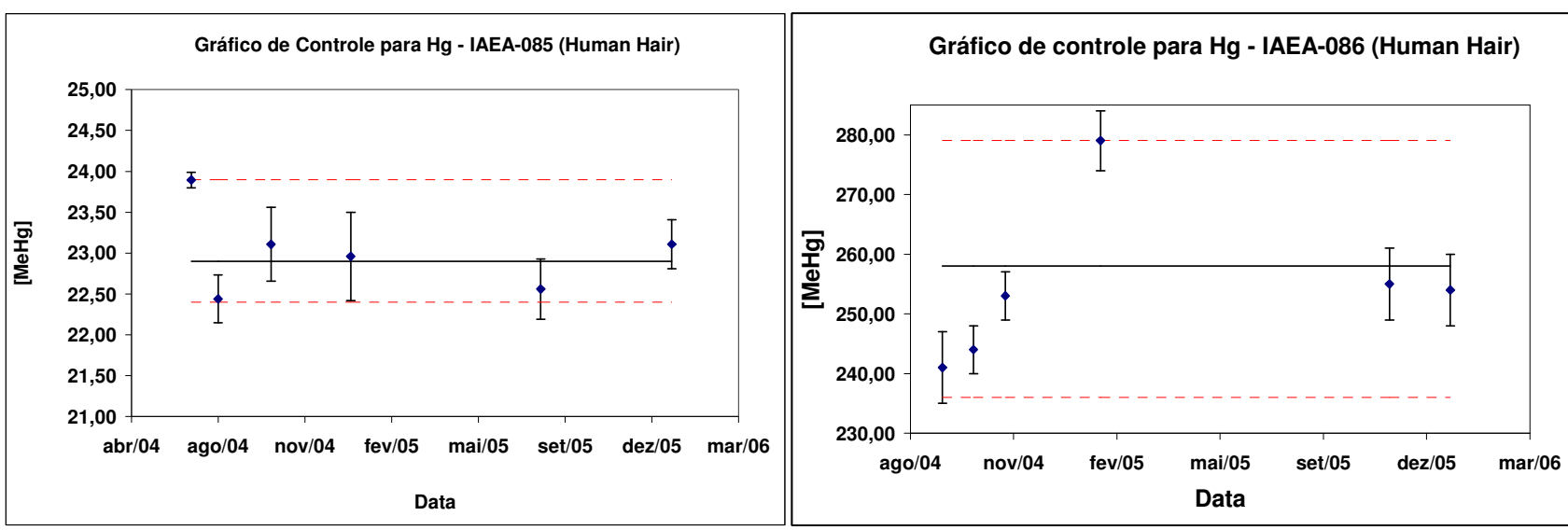

Figura 23. Gráfico de controle do procedimento proposto para análise de $\mathrm{MeHg}$ em materiais de referência. 
Uma vez obtidas as melhores condições de análise para a determinação de MeHg em cabelos por CV AAS, conforme item 5.3.1.1. do capítulo 5, efetuaram-se as análises das amostras.

\subsubsection{Resultados das análises das dietas do PNJ e comunidades próximas}

\section{Hg total em dietas}

Os valores de concentração de $\mathrm{Hg}$ obtidos para as dietas do PNJ e outras comunidades analisadas estão apresentados na Tabela 16. A partir desses dados e do consumo médio diário, foram calculados os dados de ingestão diária, para cada dieta analisada.

Os valores de ingestão diária para $\mathrm{Hg}$ nas diferentes comunidades situadas no PNJ assim como o valor de PTWI para $\mathrm{Hg}$, estão apresentados na Tabela 16. Todas as comunidades do PNJ apresentaram valores acima da ingestão considerada tolerável. As dietas de Alvarães, Itapiranga, Nhamundá, Nogueira, Novo Airão, SESI, e Urucurituba, pertencentes ao estado do Amazonas, apresentaram valores mais baixos do que aqueles encontrados nas comunidades do PNJ, sendo que algumas comunidades (Alvarães, Nogueira, Novo Airão e Urucurituba) apresentaram valores de ingestão um pouco acima da ingestão considerada tolerável. Para todas as comunidades foi considerado o peso corpóreo em média, de $10 \mathrm{~kg}$ para cada criança.

Os resultados obtidos nas análises das dietas indicaram altos níveis de $\mathrm{Hg}$ total, particularmente as comunidades de Santo Elias $\left(803 \mu \mathrm{g} \mathrm{kg}^{-1}\right)$ e Vista Alegre $\left(645 \mu \mathrm{g} \mathrm{kg}^{-1}\right)$. Para as localidades que não pertencem ao PNJ, realmente verificou-se níveis bem mais baixos de Hg. Pôdese ainda observar, que esses teores menores de $\mathrm{Hg}$ podem ser justificados analisando-se a composição das dietas do PNJ e demais comunidades (item 5.2.1). A prática alimentar mais variada, sugere uma menor ingestão de peixe.

As grandes distâncias, o isolamento decorrente da descontinuidade, a concentração da produção, dificultando o acesso ao trabalho, bens, serviços e mercados e o isolamento das comunidades do PNJ nas frentes de expansão e na unidade de conservação, favorecem essas diferenças. 
Tabela 16 - Concentração de Hg Total em dietas e Ingestão Diária de Hg de crianças em idade pré-escolar, da região Amazônica

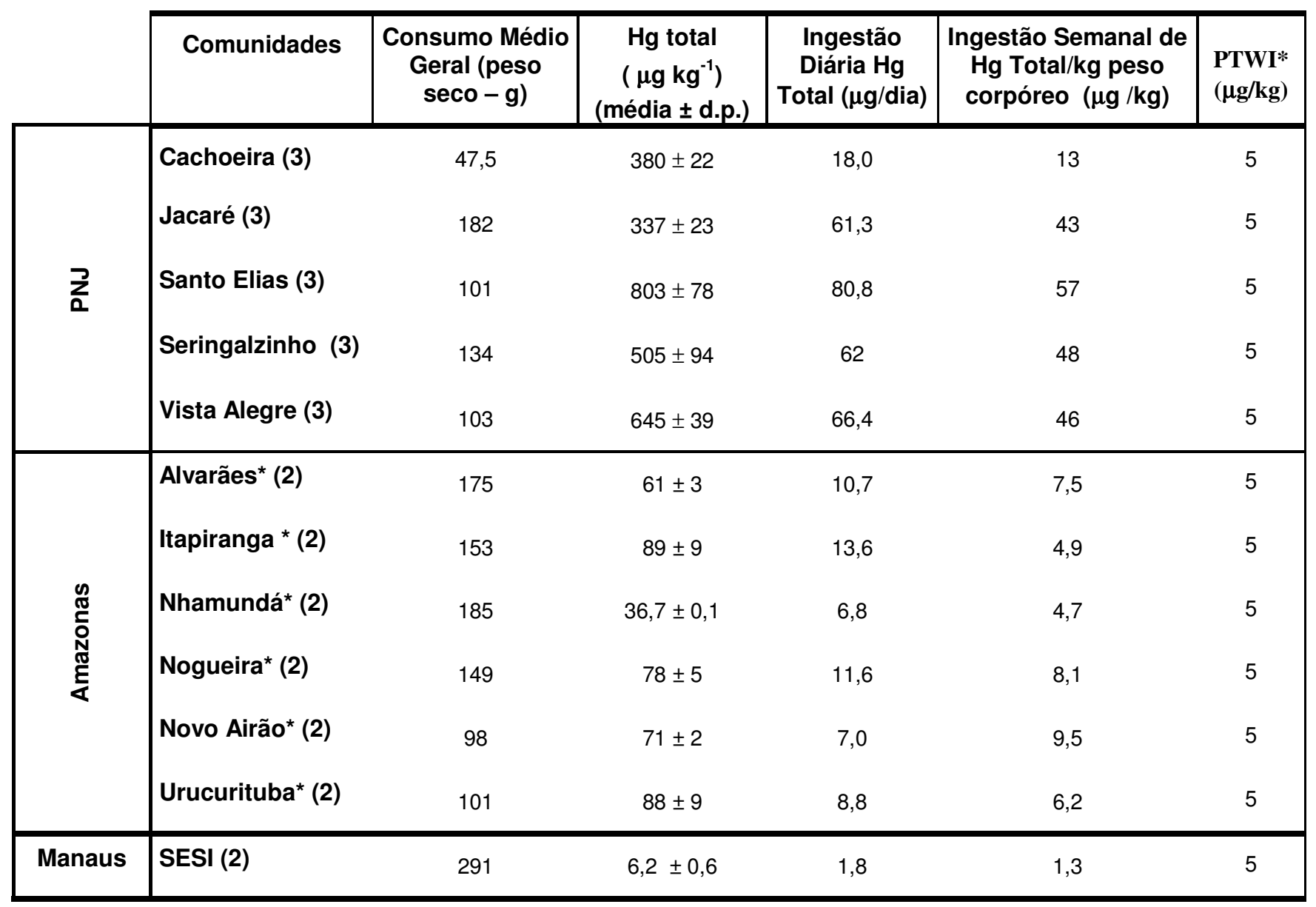

(n) - número de determinações.

*Comunidades não pertencentes ao Parque Nacional do Jaú, região Amazônica.

**PTWI - Ingestão Semanal Tolerável Provisória ( $5 \mu \mathrm{g} / \mathrm{Hg} / \mathrm{kg}$ por peso corpóreo) (WHO, 1996) - neste caso o peso corpóreo foi considerado em média, como $10 \mathrm{~kg}$ para cada criança.

Comparando-se os níveis de $\mathrm{Hg}$ em dietas de diferentes regiões brasileiras, encontrados por outros pesquisadores: dieta de Santa Catarina ${ }^{\mathrm{a}}\left(9,0 \pm 0,5 \mu \mathrm{g} \mathrm{kg}^{-1}\right.$ ), Santa Catarina ${ }^{\mathrm{b}}\left(22 \pm 3 \mu \mathrm{g} \mathrm{kg}^{-1}\right)$, Mato Grosso $\left(87 \pm 9 \mu \mathrm{g} \mathrm{kg}^{-1}\right)$ e Manaus $\left(87 \pm 4 \mu \mathrm{g} \mathrm{kg}^{-1}\right.$ ), com os níveis encontrados no presente trabalho, verificou-se que as dietas do PNJ apresentam valores no mínimo 15 vezes acima daqueles encontrados em Santa Catarina, por exemplo (Fávaro e col., 1994). Vale salientar que todas as dietas regionais continham peixe na sua composição, mas somente Mato Grosso e Manaus continham peixes procedentes da região Amazônica e uma maior proporção deles na dieta. 
A ORGANIZAÇÃO MUNDIAL DE SAÚDE (WHO, 1994), através da Comissão do Codex Alimentarius da FAO/WHO estabelece, além das necessidades nutricionais para alguns nutrientes, também os valores de ingestão semanal tolerável provisória (PTWI) ou os valores de ingestão diária aceitável (ADI) para os elementos tóxicos ou potencialmente tóxicos, como alumínio, arsênio, $\mathrm{Cd}$, $\mathrm{Hg}$, Sn e $\mathrm{Pb}$, no caso do Hg, $5 \mu \mathrm{g}$ por kg de peso corpóreo por semana (WHO, 1990). Ambos, adultos e crianças sofrem os efeitos deletérios decorrentes da ingestão de $\mathrm{Hg}$, mas particularmente as crianças apresentam uma sensibilidade especial, quando expostas a este elemento, visto poderem apresentar danos ao desenvolvimento do sistema nervoso. No caso da exposição pré-natal também pode ocorrer o comprometimento do desenvolvimento neurológico do feto (Redwood e col., 2001).

Novas pesquisas mostram que efeitos adversos podem ser causados por exposição a baixas concentrações de $\mathrm{Hg}$ e estudos epidemiológicos sugerem que efeitos sutis no sistema nervoso podem estar associados com exposições previamente consideradas seguras (Environmental Research, 1998). Além disso, dietas deficientes podem favorecer os efeitos deletérios do $\mathrm{Hg}$ e principalmente do $\mathrm{MeHg}$, pois o $\mathrm{Hg}$ assim como alguns outros elementos, pode afetar acentuadamente o metabolismo de alguns constituintes essenciais, tais como $\mathrm{Cu}, \mathrm{Zn}$ e Se, pois competem com esses elementos por ligantes do sistema biológico (Campos e col., 2002). Alguns estudos sugerem também, que uma ingestão adequada de selênio, pode ter um efeito de proteção contra o Hg e seu compostos tóxicos (Campos e col., 2002; Pinheiro e col., 2005).

\section{Análise estatística descritiva}

Os resultados de teste ANOVA com um nível de 5\% de significância e teste de Tukey de gama múltiplo, indicaram que há uma diferença estatística significativa entre o teor de $\mathrm{Hg}$ total nas dietas das comunidades do PNJ ( $\mathrm{p}<0,05)$. Porém, nenhuma diferença significativa foi observada para o teor de $\mathrm{Hg}$ total nas dietas entre as comunidades de Cachoeira/Jacaré e Vista Alegre/Seringalzinho ( $\mathrm{p}>0,05)$. Todos os valores de $\mathbf{p}$ para o teste de Shapiro-Wilk foram maiores do que 0,05 , o que significa que o teor de $\mathrm{Hg}$ total nas dietas em cada comunidade tem distribuição normal: Cachoeira ( $\mathrm{p}$-valor $=0,4391)$; Jacaré $(\mathrm{p}$-valor $=0,8089)$; Santo Elias $(\mathrm{p}$-valor $=0,9069)$; Seringalzinho ( $\mathrm{p}$-valor $=0,9383)$; Vista Alegre $(\mathrm{p}$-valor $=0,7861)$.

Após verificação da normalidade dos dados foi realizado um teste $\mathbf{F}$, com um nível de $95 \%$ de significância, para verificação da homogeneidade das variâncias. $\mathrm{O}$ valor de p para este teste foi 
de 0,458; assim a hipótese de discrepâncias homogêneas para o teor de $\mathrm{Hg}$ total para as dietas das comunidades estudadas foi aceita.

Os valores de $\mathrm{Hg}$ total nas dietas podem ser observados na Figura 24, o traço central de cada boxplot representa a mediana. Os teores são diferentes, com exceção de dois pares, Cachoeira e Jacaré, Vista Alegre e Seringalzinho. A comunidade Santo Elias apresentou um valor consideravelmente maior que os outros. A Figura 24 também mostra que não há nenhum valor contraditório dentro de cada comunidade, ou seja, nenhum outlier foi observado para o teor de $\mathrm{Hg}$ total nas dietas destas comunidades.

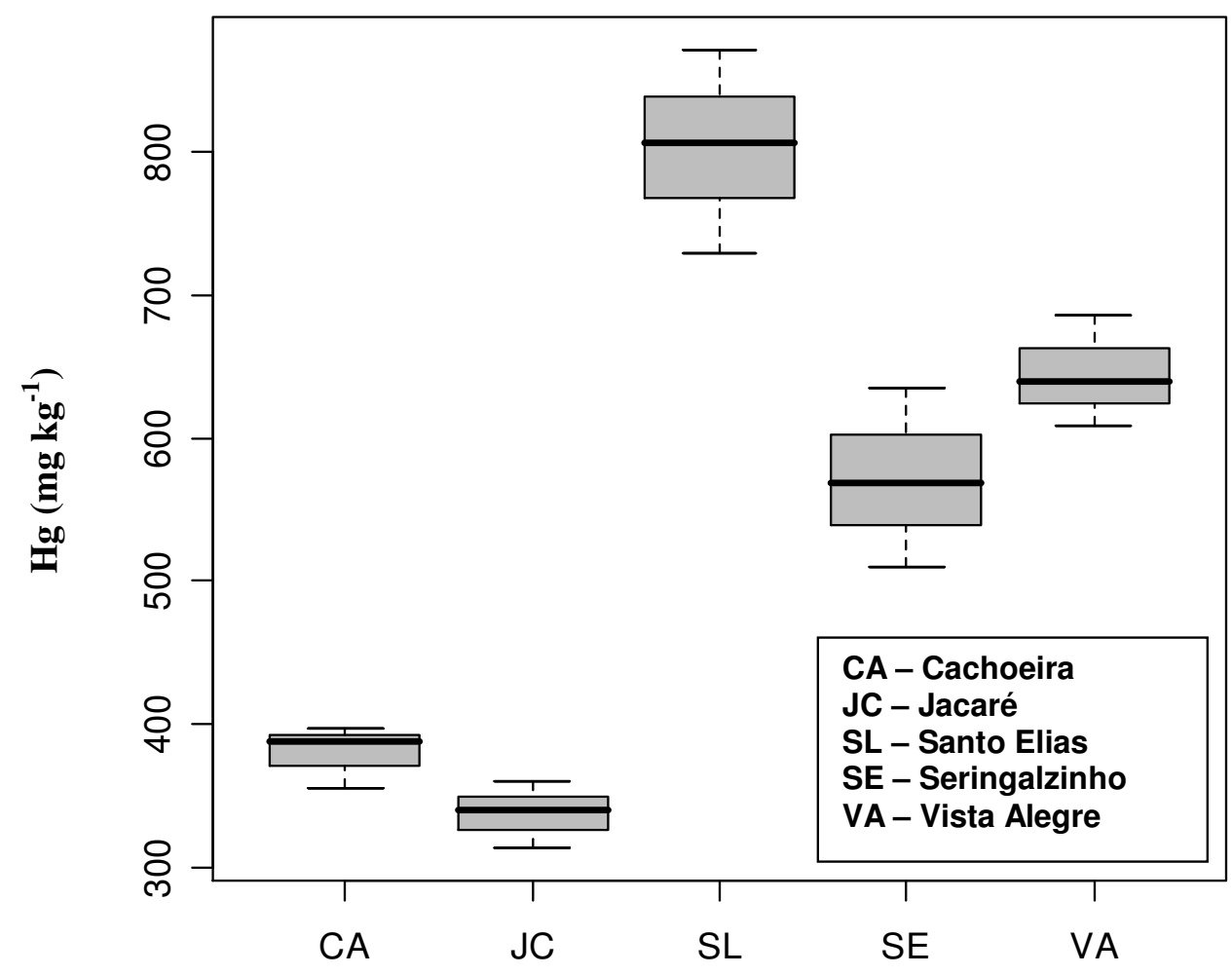

\section{Comunidades}

Figura 24. Distribuição percentual de $\mathrm{Hg}$ total em dietas das comunidades do PNJ.

A Figura 25 apresenta o intervalo de confiança para a diferença entre as médias de $\mathrm{Hg}$ total nas dietas das comunidades estudadas. Só dois pares apresentaram o mesmo intervalo de confiança que inclui o zero, Cachoeira e Jacaré e Vista Alegre e Seringalzinho. O teste de Tukey já havia confirmado esta conclusão, na qual o teor de $\mathrm{Hg}$ total não difere estatisticamente. 


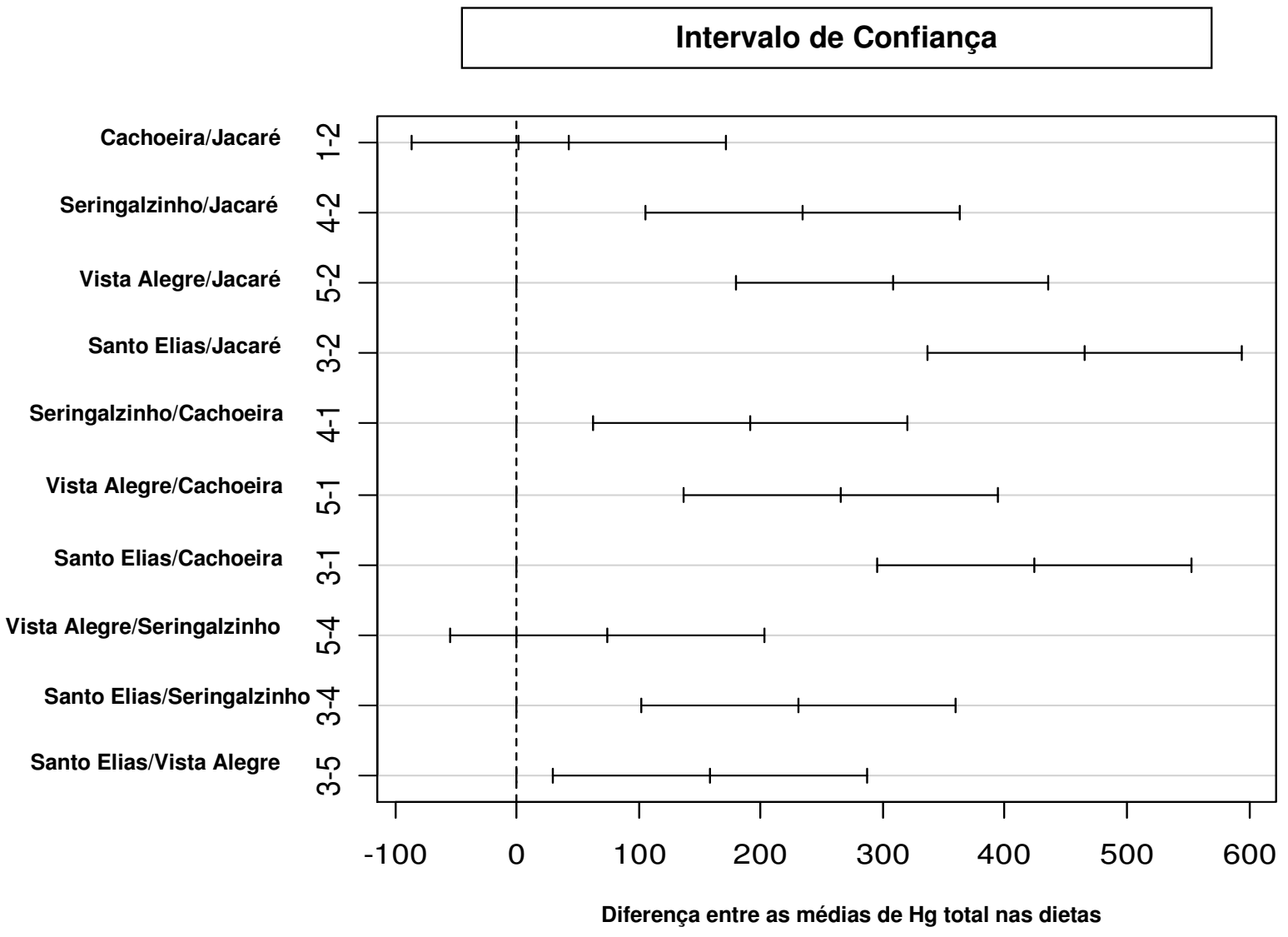

Figura 25. Intervalo de confiança entre as médias de $\mathrm{Hg}$ total nas dietas das comunidades estudadas.

Os valores para $\mathrm{Hg}$ total nas dietas, com os desvios padrões e as incertezas expandidas para as comunidades do PNJ e demais comunidades da região Amazônica estão apresentados na Tabela 17, anexo III.

\subsubsection{Resultados das análises de cabelo das comunidades do PNJ}

\subsubsection{Mercúrio total}

O cabelo é o indicador biológico escolhido quando se intenta dimensionar a exposição antiga ao $\mathrm{Hg}$ e ao MeHg. Por isso, é particularmente empregado nas pesquisas de avaliação da exposição ambiental da população geral representada por pessoas sem histórico de contato 
profissional com o $\mathrm{Hg}$. É particularmente útil para o levantamento do grau de exposição ao $\mathrm{MeHg}$ veiculado por alimentos contaminados (Holsbeek et al., 1996).

Os resultados das análises dos cabelos das crianças do Parque Nacional do Jaú e demais comunidades da região, em relação ao teor de Hg total, estão apresentados na Tabela 18.

Tabela 18 . Resultados obtidos nas determinações de Hg total em amostras de cabelos $\left(\mathrm{mg} \mathrm{kg}^{-1}\right)$ de crianças em idade pré-escolar de diferentes ecossistemas amazônicos

\begin{tabular}{|c|c|c|c|c|}
\hline & Comunidades & $\begin{array}{c}\mathrm{Hg}_{\text {total }}\left(\mathrm{mg} \mathrm{kg}^{-1}\right) \\
\text { intervalo }\end{array}$ & $\begin{array}{c}\text { Média } \\
\left(\mathrm{mg} \mathrm{kg}^{-1}\right)\end{array}$ & $\begin{array}{l}\text { Mediana } \\
\left(\mathrm{mg} \mathrm{kg}^{-1}\right)\end{array}$ \\
\hline \multirow{4}{*}{ z } & Cachoeira (4) & $1,39-22,7$ & 15,8 & 19,5 \\
\hline & Seringalzinho (5) & $0,60-36,1$ & 12,8 & 9,4 \\
\hline & Vista Alegre (4) & $13,36-23,3$ & 18,4 & 18,4 \\
\hline & Santo Elias (6) & $25,9-42,2$ & 37,2 & 39,4 \\
\hline \multirow{5}{*}{ 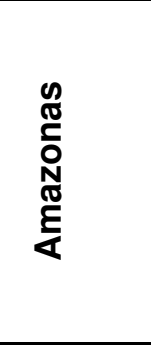 } & Ajuricaba* (5) & $12,9-22,5$ & 17,0 & 15,8 \\
\hline & Alvarães* (4) & $5,1-15,5$ & 10,2 & 11,8 \\
\hline & Borba* $^{*}(5)$ & $1,8-14,1$ & 6,6 & 4,8 \\
\hline & Itapiranga * $(5)$ & $5,6-18,6$ & 10,0 & 8,0 \\
\hline & Nhamundá* (5) & $1,1-10,6$ & 5,4 & 3,8 \\
\hline Manaus & SESI (5) & $0,58-3,8$ & 1,8 & 1,1 \\
\hline
\end{tabular}

*Demais comunidades da região Amazônica.

*(n) - número de amostras analisadas.

Os resultados obtidos novamente indicam altos níveis de $\mathrm{Hg}$, particularmente as comunidades Santo Elias e Vista Alegre. Comparando estes resultados com as dietas, observamos que os valores obtidos para a análise de cabelo nestas comunidades, coincidem com os altos valores de ingestão obtidos para estas duas comunidades, principalmente para a comunidade Santo Elias. A comunidade de Ajuricaba (calha do Rio Negro) apresentou valores próximos das comunidades do PNJ. De acordo com a Organização Mundial de Saúde (WHO, 1990), o valor de $50 \mathrm{mg} \mathrm{kg}^{-1}$ de $\mathrm{Hg}$ encontrado em cabelos de grupos com alto consumo de peixe, já está associado a 5\% de risco de danos neurológicos em adultos, lembrando que as crianças são muito mais sensíveis aos efeitos deletérios do $\mathrm{Hg}$ e $\mathrm{MeHg}$. Os valores de mediana encontrados no presente trabalho variaram de 1,1 a $39,4 \mathrm{mg} \mathrm{kg}^{-1}$ para estas comunidades. 
Saiki e colaboradores (1998), analisaram amostras de cabelo em um grupo controle residente em São Paulo (sem qualquer tipo de exposição ambiental) e encontraram valores de mediana de 1 $\mathrm{mg} \mathrm{kg}^{-1}$ para Hg, lembrando que a Organização Mundial da Saúde (WHO, 1996) estabelece o valor de $2 \mathrm{mg} \mathrm{kg}^{-1}$ para $\mathrm{Hg}$ em cabelos de população adulta, sem exposição ocupacional.

O teor médio de $\mathrm{Hg}$ total em cabelos obtido em vários estudos realizados na população do estado do Amazonas foi de 19,1 $\mathrm{mg} \mathrm{kg}^{-1}$ (Souza \& Barbosa, 2000), próximo ao obtido neste estudo. Esse valor pode ser considerado alto, merecendo especial atenção de organismos governamentais responsáveis pelo meio ambiente e saúde da população brasileira.

Contudo, apesar dos altos valores encontrados neste trabalho, a eliminação do $\mathrm{Hg}$ total e MeHg e o desenvolvimento de sinais e sintomas de intoxicação dependem de fatores genéticos ainda desconhecidos que, de certa forma, protegem o indivíduo da intoxicação. Estes fatores estão relacionados com o sexo, a idade, hormônios, a taxa de hemoglobina e a capacidade de indução das melaotioneínas, que podem funcionar como barreiras protetoras do cérebro e sobretudo do cerebelo, onde o acúmulo é mais pronunciado.

Estudos recentes vêm confirmando que fatores genéticos podem influenciar e muito a acumulação de Hg no organismo. Guimarães-Klautau e col. (2005), avaliando a suscetibilidade à contaminação por $\mathrm{Hg}$ e sua relação com o polimorfismo da enzima glutationa S-transferase (GST), por meio de biomarcadores moleculares em algumas tribos indígenas da Amazônia verificou que indivíduos que possuíam o fenótipo GSTM1 inativo apresentaram teores de $\mathrm{Hg}$ em cabelos muito mais altos do que indivíduos que possuíam o fenotipo GSTM1+/+ ativo, sugerindo que a GSTM1 pode estar envolvida na biotransformação do $\mathrm{Hg}$ em humanos.

Os valores para $\mathrm{Hg}$ total nos cabelos, com os desvios padrões e as incertezas expandidas para as comunidades do PNJ e demais comunidades da região Amazônica, estão apresentados nas Tabelas 19 e 20, anexos IV e V.

\subsubsection{Metilmercúrio}

Os resultados das análises dos cabelos das crianças do PNJ e comunidades próximas, em relação ao teor de MeHg, estão apresentados na Tabela 21. 
Devido à quantidade de cabelo coletada ter sido muito pequena, não foi possível determinar $\mathrm{Hg}$ total e MeHg na mesma amostra. Dessa forma, parte das amostras de cabelo foram analisadas para $\mathrm{Hg}$ total e parte para $\mathrm{MeHg}$, escolhidas aleatoriamente.

Os níveis de $\mathrm{MeHg}$ nos cabelos das crianças do PNJ foram altos, quando comparados a valores obtidos para crianças residentes nas demais localidades da região Amazônica. Isto indica que a ingestão diária de peixe entre as crianças do PNJ é alta. O consumo de peixe é normalmente considerado como o principal caminho para a bioacumulação do $\mathrm{MeHg}$ em humanos e a monotonia do cardápio pode ter favorecido esta ingestão, já que para essas comunidades bem como para outras comunidades ribeirinhas do Amazonas, a principal fonte de proteínas advém da ingestão de peixes. $\mathrm{O}$ alto consumo de peixe na região é confirmado pela literatura, já que a pesca de peixe no estado do Amazonas é de aproximadamente 125 mil toneladas/ano, sendo considerada a maior produção de peixe de água doce do país, chegando a atingir $30 \%$ da produção total, sendo também exportadora para outras regiões (SUFRAMA, 2000).

Tabela 21 . Resultados obtidos nas determinações de MeHg em amostras de cabelos $\left(\mathrm{mg} \mathrm{kg}^{-1}\right)$ de crianças em idade pré-escolar do PNJ e diferentes ecossistemas amazônicos

\begin{tabular}{|c|c|c|c|c|}
\hline & Comunidades & $\begin{array}{c}\text { MeHg (mg kg-1) } \\
\text { Intervalo }\end{array}$ & $\begin{array}{c}\text { Média } \\
\left(\mathrm{mg} \mathrm{kg}^{-1}\right)\end{array}$ & $\begin{array}{l}\text { Mediana } \\
\left(\mathrm{mg} \mathrm{kg}^{-1}\right)\end{array}$ \\
\hline \multirow{4}{*}{$\bar{Z}$} & Cachoeira (3) & $27,9-55,0$ & 40,9 & 39,6 \\
\hline & Santo Elias (6) & $28,3-74,4$ & 55,1 & 55,6 \\
\hline & Seringalzinho (3) & $20,6-73,3$ & 47,2 & 47,6 \\
\hline & Vista Alegre (3) & $35,7-59,8$ & 45,1 & 42,4 \\
\hline \multirow{5}{*}{ 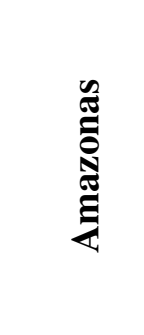 } & Alvarães* (5) & $1,3-9,9$ & 3,6 & 2,8 \\
\hline & Ajuricaba* (3) & $9,2-25,6$ & 18,9 & 21,3 \\
\hline & Borba* (5) & $1,5-10,1$ & 5,1 & 4,9 \\
\hline & Nhamundá* (4) & $1,5-2,1$ & 1,9 & 1,9 \\
\hline & Itapiranga* (6) & $1,3-9,9$ & 3,8 & 2,8 \\
\hline Manaus & SESI (4) & $0,27-3,84$ & 2,29 & 2,8 \\
\hline
\end{tabular}

*Comunidades da região Amazônica.

*(n) - número de amostras analisadas. 
Valores de concentração para $\mathrm{Hg}$ em cabelo, considerados como valores de referência para pessoas não expostas estão entre 1 e $2 \mathrm{mg} \mathrm{kg}^{-1}$ (Mitra, 1986; Galvão \& Corey, 1987). Desde 1990, a WHO, preocupada com a ingestão de metilmercúrio e seu acúmulo no organismo, estabeleceu provisoriamente o valor de $6 \mathrm{mg} \mathrm{kg}^{-1}$ em cabelos como sendo a concentração correspondente a uma ingestão semanal tolerável provisória do elemento (WHO, 1990).

Os valores de MeHg no cabelo, com os desvios padrões e as incertezas expandidas para as comunidades do PNJ e demais comunidades da região Amazônica estão apresentados nas Tabelas 22 e 23, anexos VI e VII.

\subsubsection{Resultados das análises dos peixes da cidade de Manaus - mercúrio total}

Durante a última década, inúmeros estudos têm reportado que peixes de alguns rios da Amazônia estão contaminados com $\mathrm{Hg}$ ou apresentam uma concentração mais alta do que aqueles de outras regiões. Segundo Dórea e colaboradores (1998), as concentrações de Hg total em peixes piscívoros, onívoros e herbívoros de 12 diferentes locais do Rio Madeira (Amazônia), variaram de 0,09 a $1,45 \mathrm{mg} \mathrm{kg}^{-1}$ dependendo da espécie considerada. Muitos outros trabalhos apresentaram teores de $\mathrm{Hg}$ total em peixes na faixa de 0,01 até $2,7 \mathrm{mg} \mathrm{kg}^{-1}$, excedendo o limite máximo de tolerância para $\mathrm{Hg}$ total de $1 \mathrm{mg} \mathrm{kg}^{-1}$ para peixes predadores e $0,5 \mathrm{mg} \mathrm{kg}^{-1}$ para peixes não predadores e produtos da pesca, conforme preconizado pela Agência Nacional de Vigilância Sanitária (ANVISA, 1998; Pfeifer e col., 1989; Barbosa e col., 1995; Malm e col., 1997; Lechler e col., 2000; Belger, 2001).

O peixe é uma das principais fontes de proteínas para vários grupos populacionais, particularmente para a população ribeirinha da Amazônia (Araújo-Lima \& Golding, 1998). Contudo, a despeito da grande quantidade de informação existente em relação ao teor de $\mathrm{Hg}$ em várias espécies desta região, estas se referem na maioria das vezes à composição química do peixe in natura e não à forma em que os peixes são usualmente consumidos pela população. Dessa forma, considerando a relevância do monitoramento do consumo de alimentos em uma população, avaliouse também o teor de $\mathrm{Hg}$ em espécies de peixes comumente consumidas pela população da cidade de Manaus e comunidades próximas, preparadas sob diferentes formas de cocção. 
A Tabela 24 apresenta os resultados obtidos para o teor de $\mathrm{Hg}$ nas amostras de peixes preparadas sob diferentes formas de cocção e as respectivas perdas de $\mathrm{Hg}(\%)$.

Os peixes, alimentam-se de formas distintas, segundo particularidades de cada espécie a ser considerada. No presente estudo, estabeleceram-se seis categorias de hábitos alimentares (adaptado a partir de Batistella e col., 2005):

- herbívoros - alimentam-se de plantas que crescem na água;

- carnívoros - alimentam-se de pequenos peixes e outros animais;

- detritívoros - alimentam-se de detritos de matéria orgânica do fundo dos rios ou de tanques de criação.

- onívoros - alimentam-se com quase tudo o que encontram. Seu hábito alimentar varia bastante conforme a época do ano, disponibilidade de alimentos, local ou até conforme a idade do peixe;

- piscívoros - alimentam-se de pequenos peixes.

Os valores de $\mathrm{Hg}$ total nos peixes, com os desvios padrões e as incertezas expandidas para os bairros de Manaus, avaliados neste estudo, estão apresentados na Tabela 25, anexo VIII.

$\mathrm{O}$ teor médio de $\mathrm{Hg}$ nas amostras analisadas in natura variou de $49 \mu \mathrm{g} \mathrm{kg}^{-1}$ a $2393 \mu \mathrm{g} \mathrm{kg}^{-1} \mathrm{e}$ depois do processo de cocção, de $19 \mu \mathrm{g} \mathrm{kg}^{-1}$ a $1674 \mu \mathrm{g} \mathrm{kg}^{-1}$ (Tabela 24). As perdas de $\mathrm{Hg}$ variaram de 0 a $75 \%$ e as maiores perdas foram verificadas para o peixe frito, seguidas do peixe cozido. As menores perdas foram encontradas no peixe assado, indicando que a maior parte do $\mathrm{Hg}$ ficou retida na amostra, portanto sujeita à ingestão. Tal como esperado, ocorreram perdas modestas nas amostras de peixes assadas e cozidas, alcançando um valor mínimo de $0 \%$ para a espécie Curimatã e 5,8\% para a Pescada, respectivamente. Contudo, perdas maiores ocorreram para duas espécies, que foram assadas e cozidas, apresentando um valor máximo de $68 \%$ para o Aracu, $61 \%$ para o Pirapitinga e $75 \%$ para o Surubim, respectivamente. A variabilidade na \% de perda de $\mathrm{Hg}$, para cada processo de cocção, parece estar mais em função da espécie do que em função da forma de preparo.

Isso pode ser explicado, visto que as espécies bioacumulam o $\mathrm{Hg}$ em proporções diferentes (predadores mais do que não predadores, como por exemplo, o Tucunaré, espécie carnívora, a qual apresentou os valores elevados de $\mathrm{Hg}$ ). No entanto, verifica-se uma perda mais acentuada no processo de fritura para a maioria das espécies, no qual a temperatura pode chegar a $150^{\circ} \mathrm{C}$, apesar das ligações $\mathrm{Hg}-\mathrm{S}$, que mantêm o metal ligado às proteínas do músculo do peixe, serem fortes (Malm, 1993). O óleo da fritura pode agir como extrator de parte do MeHg (lipossolúvel) do peixe 
e, a perda se dá posteriormente, por volatização do Hg aí dissolvido (Suzuki e col, 1991; Azevedo, 2003).

As espécies Aruanã (onívoro), Pescada (piscívoro), Surubim (piscívoro) e Tucunaré (carnívoro), excederam o limite da ANVISA (1998) de $1 \mathrm{mg} \mathrm{kg}^{-1}$ para $\mathrm{Hg}$ total, tanto para o peixe in natura quanto depois de preparado, nos três processos utilizados. As demais espécies de peixe analisadas apresentaram teores de $\mathrm{Hg}$ dentro do limite da legislação da brasileira.

Apesar das amostras assadas e cozidas apresentarem uma perda menor em comparação ao processo de fritura, no conjunto das amostras analisadas nota-se que para algumas espécies Aracu e Pirapitinga, estes valores não parecem se diferenciar muito. Para algumas espécies (Pescada e Tucunaré), esses processos de cocção também não se mostraram suficientes para diminuir significativamente o risco à exposição a este metal, em populações que consomem peixes com altos teores de $\mathrm{Hg}$ em grande quantidade e frequiência. 
Tabela 24 . Resultados obtidos na análise dos peixes preparados sob diferentes formas de cocção $\left(\mu \mathrm{kg}^{-1}\right)$ e perda percentual de $\mathrm{Hg}(\mathrm{P} \%)$

\begin{tabular}{|c|c|c|c|c|c|c|c|c|c|c|c|c|c|c|c|c|c|c|c|c|c|c|c|c|}
\hline & \multicolumn{2}{|c|}{ Aracu } & \multicolumn{2}{|c|}{ Aruanã } & \multicolumn{2}{|c|}{ Branquinha } & \multicolumn{2}{|c|}{ Curimatã } & \multicolumn{2}{|c|}{ Jaraqui } & \multicolumn{2}{|c|}{ Pacu } & \multicolumn{2}{|c|}{ Pescada } & \multicolumn{2}{|c|}{ Pirapitinga } & \multicolumn{2}{|c|}{ Sardinha } & \multicolumn{2}{|c|}{ Surubim } & \multicolumn{2}{|c|}{ Tambaqui } & \multicolumn{2}{|c|}{ Tucunaré } \\
\hline & \multicolumn{2}{|c|}{ Herbivoro ${ }^{a}$} & \multicolumn{2}{|c|}{ Onivoro ${ }^{\mathrm{a}}$} & \multicolumn{2}{|c|}{ Detritivoro $^{\mathrm{a}}$} & \multicolumn{2}{|c|}{ Detritivoro $^{\mathrm{a}}$} & \multicolumn{2}{|c|}{ Detritivoro a } & \multicolumn{2}{|c|}{ Herbivoro ${ }^{a}$} & \multicolumn{2}{|c|}{ Piscivoro } & \multicolumn{2}{|c|}{ Herbivoro ${ }^{a}$} & \multicolumn{2}{|c|}{ Onivoro ${ }^{\mathrm{a}}$} & \multicolumn{2}{|c|}{ Piscivoro ${ }^{b}$} & \multicolumn{2}{|c|}{ Onivoro ${ }^{\mathrm{a}}$} & \multicolumn{2}{|c|}{ Carnivoro $^{\mathrm{C}}$} \\
\hline & $\mathrm{Hg}$ & $\mathbf{P}(\%)$ & $\mathrm{Hg}$ & $\mathbf{P}(\%)$ & $\mathrm{Hg}$ & P (\%) & $\mathrm{Hg}$ & P (\%) & $\mathrm{Hg}$ & $\mathbf{P}(\%)$ & $\mathrm{Hg}$ & P (\%) & $\mathrm{Hg}$ & $\mathbf{P}(\%)$ & $\mathrm{Hg}$ & P (\%) & $\mathrm{Hg}$ & P (\%) & $\mathrm{Hg}$ & P (\%) & $\mathrm{Hg}$ & P (\%) & $\mathrm{Hg}$ & P (\%) \\
\hline IN NATURA & 410 & & 2393 & & 194 & & 73 & & 995 & & 71 & & 1401 & & 49 & & 275 & & 937 & & 151 & & 1302 & \\
\hline ASSADO & 129 & 68 & 1674 & 30 & 117 & 40 & 73 & 0 & 963 & 3 & 56 & 21 & 1328 & 5 & 46 & 6 & 261 & 5,1 & 1138 & - & 142 & 6 & 1102 & 15 \\
\hline COZIDO & 270 & 66 & 588 & 75 & 161 & 17 & 35 & 52 & 680 & 32 & 43 & 39 & 1320 & 6 & 19 & 61 & 293 & - & 1604 & - & 129 & 15 & 1187 & 9 \\
\hline FRITO & 120 & 71 & - & - & 133 & 31 & 37 & 51 & 445 & 55 & 37 & 48 & 1163 & 17 & 22 & 55 & 253 & 8 & 755 & 19 & 101 & 33 & 1062 & 18 \\
\hline $\begin{array}{c}\text { Peso (g) } \\
\text { média } \pm \text { d.p. }\end{array}$ & \multicolumn{2}{|c|}{$231 \pm 40$} & \multicolumn{2}{|c|}{$1376 \pm 561$} & \multicolumn{2}{|c|}{$201 \pm 13$} & \multicolumn{2}{|c|}{$633 \pm 54$} & \multicolumn{2}{|c|}{$292 \pm 32$} & \multicolumn{2}{|c|}{$148 \pm 17$} & \multicolumn{2}{|c|}{$1320 \pm 875$} & \multicolumn{2}{|c|}{$1522 \pm 395$} & 110 & \pm 34 & 1811 & \pm 932 & 2870 & \pm 1345 & 1090 & \pm 651 \\
\hline Intervalo & & 273 & $904-$ & 1996 & 179 & -222 & & -726 & 252 & 332 & & -174 & $656-$ & 2312 & 1243 & 1801 & $73-$ & 156 & 1264. & 2888 & 2084 & -4424 & $652-$ & 2197 \\
\hline
\end{tabular}

a - Batistella e col., 2005.

b - IBAMA, 2006

c - Carneiro e col., 2004. 
Estudo paralelo, conduzido pelo Laboratório de Nutrição e Físico-Química de Alimentos do INPA, Manaus, iniciou também a avaliação das características nutricionais e sensoriais destes pescados. Resultados preliminares foram obtidos para as amostras de Aracu (in natura, assado, cozido), Tucunaré (in natura), Pescada (in natura), Pacu (assado), Sardinha (in natura, frita). Em relação aos constituintes nutricionais sobressaiu-se as proteínas, como esperado, uma vez que os pescados apresentam como peculiaridade, alto teor protéico e biológico. Os lipídios foram constituintes que se destacaram e que se somaram ao óleo da fritura, contribuindo no suprimento energético. $\mathrm{O}$ teor de glicídios em pescados foi praticamente negligenciável. Entretanto, a adição de farinha de trigo nas preparações das amostras fritas, refletiu em maiores concentrações. As espécies analisadas sobressaíram-se em proteína, lipídio e energia, em particular a Sardinha, a qual também apresentou baixo teores de $\mathrm{Hg}$, sendo altamente recomendada a compor a alimentação dos amazonenses, em particular os grupos com déficit de energia e proteína (Pessoa, 2005).

\subsubsection{Resultados das análises de cabelos (Hg total e MeHg) de crianças da cidade de Manaus}

Os resultados da análise dos cabelos das crianças de seis bairros da cidade de Manaus, em relação ao teor de $\mathrm{Hg}$ total, estão apresentados na Tabela 26.

Tabela 26 . Resultados obtidos nas determinações de $\mathrm{Hg}$ total e MeHg em amostras de cabelos $\left(\mathrm{mg} \mathrm{kg}^{-1}\right)$ de crianças em idade pré-escolar de diferentes bairros da cidade de Manaus

\begin{tabular}{|c|c|c|c|c|c|}
\hline & Bairros & $\begin{array}{c}\mathrm{Hg}_{\text {total }}\left(\mathrm{mg} \mathrm{kg}^{-1}\right) \\
\text { Intervalo }\end{array}$ & $\begin{array}{c}\text { Média } \\
\left(\mathrm{mg} \mathrm{kg}^{-1}\right)\end{array}$ & $\begin{array}{l}\text { Mediana } \\
\left(\mathrm{mg} \mathrm{kg}^{-1}\right)\end{array}$ & $\begin{array}{c}\mathrm{MeHg} \\
\text { (Proporção em relação } \\
\text { ao Hg total - \%) }\end{array}$ \\
\hline \multirow{6}{*}{ 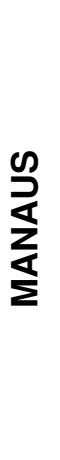 } & Alvorada (22) & $0,29-18,27$ & 2,29 & 1,23 & 47 a 97 \\
\hline & Cidade Nova (31) & $0,10-20,09$ & 2,78 & 1,71 & 47 a 95 \\
\hline & Compensa (40) & $0,07-8,64$ & 1,52 & 1,18 & 47 a 95 \\
\hline & Flores (33) & $0,19-34,36$ & 3,22 & 0,98 & 48 a 90 \\
\hline & Japiim (45) & $0,05-7,14$ & 1,33 & 0,89 & 49 a 97 \\
\hline & São José (31) & $0,06-4,66$ & 0,73 & 0,16 & 54 a 98 \\
\hline
\end{tabular}

(n) - número de amostras analisadas. 
Os valores de $\mathrm{Hg}$ total no cabelo, com os desvios padrões e as incertezas expandidas para os bairros de Manaus, avaliados neste estudo, estão apresentados nas Tabelas 27, 28, 29, 30 e 31 e anexos IX, X, XI, XII e XIII. Os valores de MeHg no cabelo, com os desvios padrões e as incertezas expandidas para os bairros de Manaus, estão apresentados nas Tabelas 32, 33, 34, 35 e 36 e anexos XIV, XV, XVI, XVII e XVIII.

$\mathrm{O}$ valor da mediana para o teor de $\mathrm{Hg}$ total nas amostras de cabelos analisadas variou de $0,16 \mathrm{mg} \mathrm{kg}^{-1}$ a $1,71 \mathrm{mg} \mathrm{kg}^{-1}$. Os valores de mediana para os teores de $\mathrm{Hg}$ total para os bairros de Manaus avaliados foram: Alvorada $1,23 \mathrm{mg} \mathrm{kg}^{-1}$; Cidade Nova $1,71 \mathrm{mg} \mathrm{kg}^{-1}$; Compensa 1,18 mg $\mathrm{kg}^{-1}$; Flores $0,98 \mathrm{mg} \mathrm{kg}^{-1}$; Japiim 0,91 $\mathrm{mg} \mathrm{kg}^{-1}$ e São José $0,16 \mathrm{mg} \mathrm{kg}^{-1}$.

\section{Análise estatística descritiva dos resultados}

Inicialmente, com o objetivo de averiguar possíveis correlações entre as variáveis peso, altura, idade, teor de $\mathrm{Hg}$ e $\mathrm{MeHg}$, utilizou-se o coeficiente de correlação de Pearson e este mostrou que há correlação significativa $(\mathrm{p}<0,05)$; entre as variáveis idade, peso e altura, conforme esperado, sendo que $\mathrm{Hg}$ e $\mathrm{MeHg}$ não apresentam correlação significativa com as demais variáveis.

Com relação ao teor de $\mathrm{Hg}$ total nas amostras de cabelo, em função do sexo, os indivíduos apresentaram características semelhantes. Em média, o teor de $\mathrm{Hg}$ nas amostras de cabelo não apresentou diferenças significativas segundo o gênero (Figura 26). O valor de mediana obtido para $\mathrm{Hg}$ total para o sexo feminino foi $0,90 \mathrm{mg} \mathrm{kg}^{-1}$ e para o sexo masculino, $1,23 \mathrm{mg} \mathrm{kg}^{-1}$, sendo que o teor de MeHg nas amostras de cabelos apresentou um teor percentual médio de 69,7 \% e 71,5\%, respectivamente. 


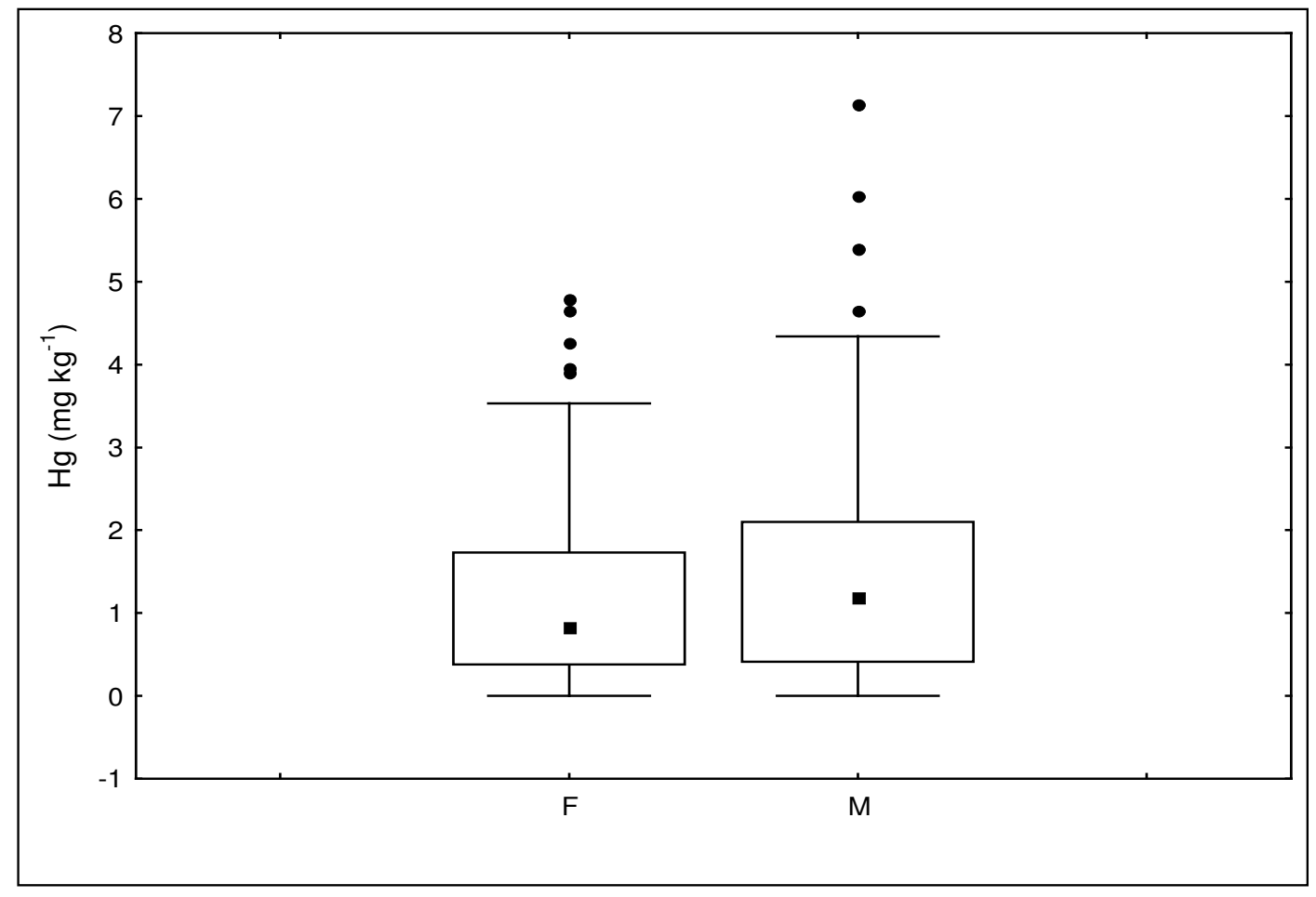

Figura 26. Boxplot da variação do teor de $\mathrm{Hg}$ total nas amostras de cabelo em função do gênero.

Com relação à variação do teor de $\mathrm{Hg}$ total e MeHg nas amostras de cabelo em função do bairro, os resultados apresentaram-se similares, exceto para o bairro São José que apresentou valores muito mais baixos (Figura 27). Interessante ressaltar, que este bairro, localizado na zona Leste da cidade, é um dos bairros mais pobres de Manaus e também o mais distante do porto. 


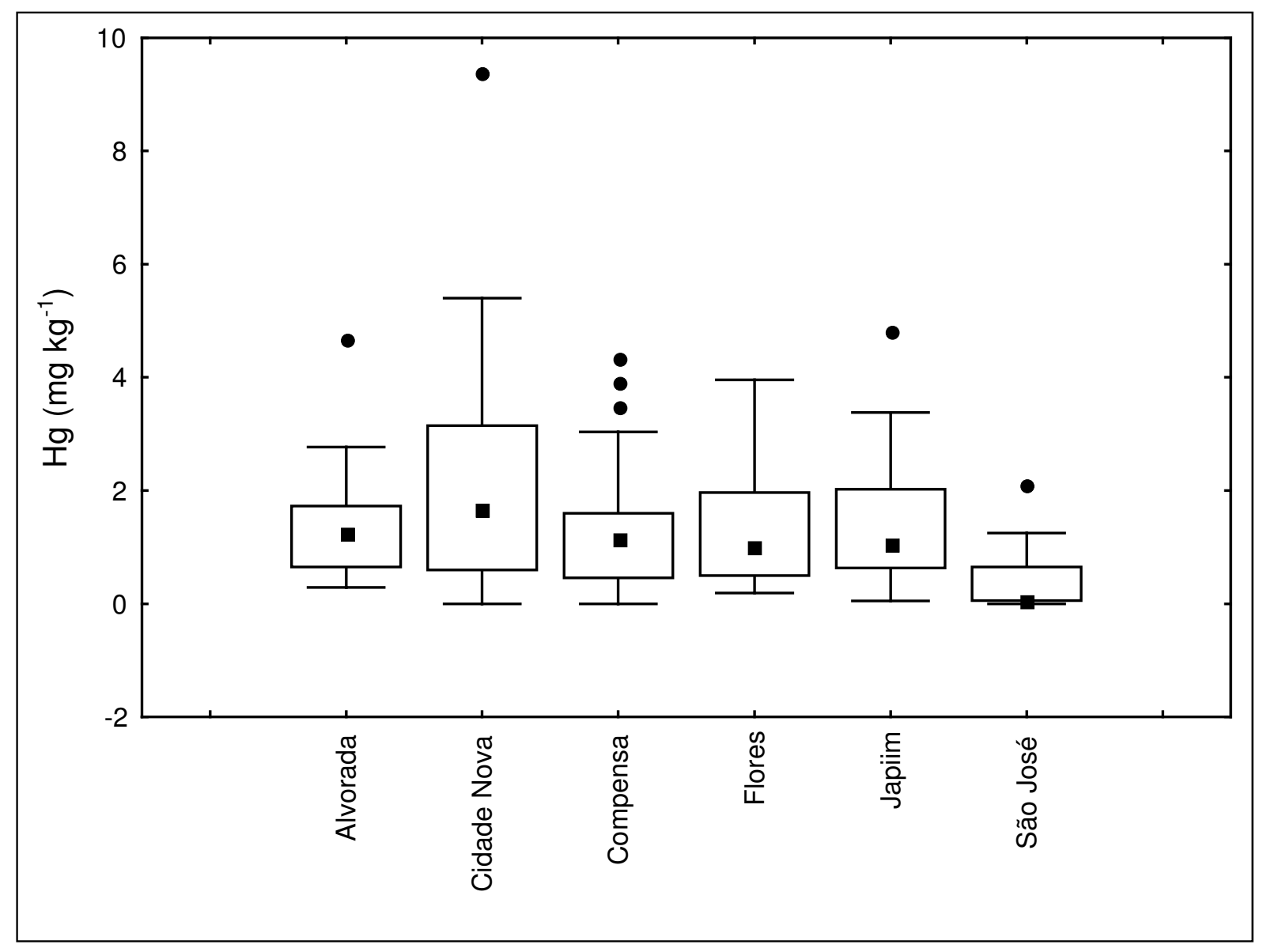

Figura 27. Boxplot indicando a variação do teor de $\mathrm{Hg}$ total nas amostras de cabelo em função do bairro.

A despeito do peixe compor freqüentemente a dieta da população da cidade de Manaus, o nível de $\mathrm{Hg}$ total nas amostras de cabelo analisadas apresentaram valores menores do que o valor preconizado pela WHO (1990), para uma população adulta não exposta ao $\mathrm{Hg}\left(2,0 \mathrm{mg} \mathrm{kg}^{-1}\right)$. Todos os bairros estudados apresentaram teores de $\mathrm{Hg}$ total e $\mathrm{MeHg}$ em cabelo, menores do que $10 \mathrm{mg} \mathrm{kg}$ ${ }^{1}$, valor considerado indicativo da presença de possíveis efeitos adversos no desenvolvimento de crianças (Souza \& Barbosa, 2000).

Os resultados obtidos no presente estudo, também estão muito mais baixos do que os valores obtidos para Hg total em cabelo da população do Amazonas ao longo dos últimos anos (conforme citado anteriormente, o teor médio de $\mathrm{Hg}$ total obtido foi de $19,1 \mathrm{mg} \mathrm{kg}^{-1}$ segundo estudo de Souza \& Barbosa (2000) 
Com relação à variação do teor de $\mathrm{Hg}$ total e $\mathrm{MeHg}$ nas amostras de cabelo em função da classe social, a classe D apresentou os maiores teores. Apesar das medianas para os teores de $\mathrm{Hg}$ total em cabelo apresentarem valores variados para as classes avaliadas (B, C, D e E), a diferença observada não é estatiscamente significante (Figura 28). Os resultados obtidos (mediana) para Hg total e o intervalo de $\mathrm{MeHg}$ (em \% do $\mathrm{Hg}$ total) nas amostras de cabelos para a população dos bairros estudados, segundo a classe social, foi: classe $\mathbf{B}$ 0,92 $\mathrm{mg} \mathrm{kg}^{-1}$ (e um intervalo de 71,1 a 90,6 $\%$ para MeHg); classe C 0,86 $\mathrm{mg} \mathrm{kg}^{-1}$ (e um intervalo de 47,1 a 93,9 \% para MeHg); classe D 1,17 $\mathrm{mg} \mathrm{kg}^{-1}$ (e um intervalo de 46,6 a 98,1\% para MeHg) e classe $\mathbf{E}$ 0,77 $\mathrm{mg} \mathrm{kg}^{-1}$ (e um intervalo de $58,0$ a $90,6 \%$ para $\mathrm{MeHg})$.

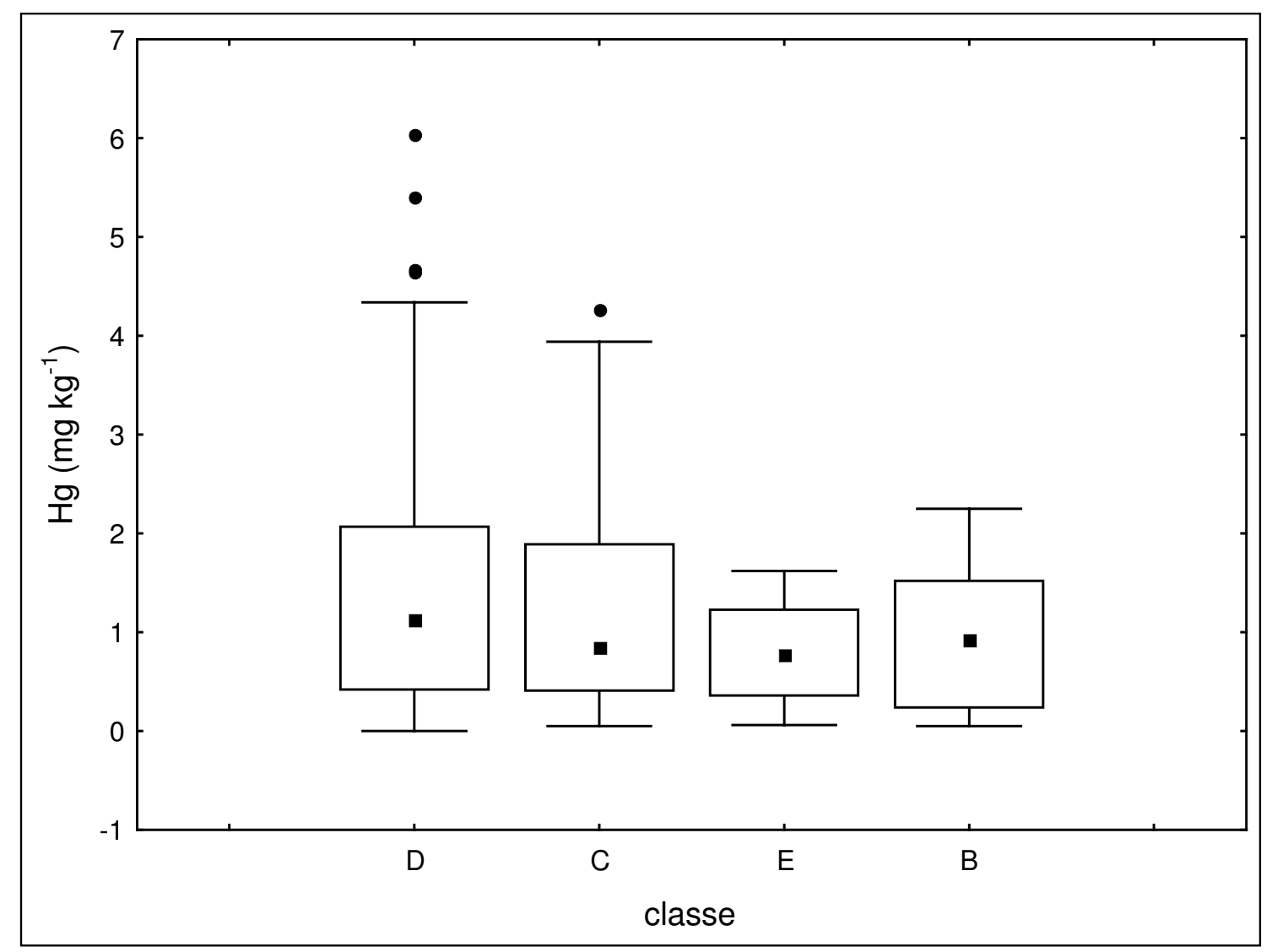

Figura 28. Boxplot da variação do teor de Hg total nas amostras de cabelo em função da classe social.

Foram realizados testes de normalidade, por meio do teste de Shapiro-Wilks, para verificação da normalidade da distribuição do teor de $\mathrm{Hg}$ por bairro amostrado. Verificou-se que em nenhum dos bairros a distribuição do teor de $\mathrm{Hg}$ é normal $(\mathrm{p}<0,05)$, assim para verificação da significância das diferenças dos teores de $\mathrm{Hg}$ por bairro, optou-se por teste não-paramétrico. Por 
meio do teste de Kruskal - Wallis, verificou-se que as diferenças no teor de Hg observadas em função do bairro não são significativas $(\mathrm{p}<0,05)$, assim como as diferenças observadas para as medianas em função das classes sociais.

Os dados antropométricos e informações obtidas a partir do questionário respondido pela mãe ou responsável para cada criança participante do estudo, estão apresentados nas Tabela 37, anexo $\mathrm{XIX}^{11}$.

\subsubsection{Comentários gerais a respeito da relação entre a ingestão de peixe e níveis de mercúrio em amostras de cabelo}

As transformações sociais e econômicas que ocorreram na região Amazônica nas últimas décadas, contribuíram para modificações no perfil alimentar da população, proporcionada por uma maior disponibilidade de alimentos industrializados nas localidades mais desenvolvidas, apesar de ainda caracterizar-se por uma expressiva diferenciação sócio-econômica entre seus moradores, especialmente entre comunidades ribeirinhas, cuja dificuldade de acesso a produtos industrializados, tornam os peixes da região a principal fonte de proteínas da população.

Focalizando os municípios de Manaus e o PNJ, temos sistemas de produção contrastantes, em que modelos sofisticados e modernos se opõem a formas "primitivas" e tradicionais de exploração e uso dos recursos naturais.

A freqüência com que as populações comem pescado é determinada pelo número de opções protéicas de uma determinada comunidade. Comunidades mais pobres, como grupos indígenas e populações ribeirinhas, exemplificada no presente estudo pelas comunidades do PNJ, que estão relativamente isoladas, têm no peixe a principal fonte de proteínas, enquanto comunidades com maior poder econômico, possuem mais opções e não consomem quantidades tão elevadas de peixe. Além do que, nas populações ribeirinhas da Amazônia o pescado está muito presente na cultura culinária destas comunidades.

Portanto, o aspecto econômico e social, juntamente com o fato de ser o peixe a mais importante via de entrada do $\mathrm{MeHg}$ no homem, pode explicar por que a população de Manaus

\footnotetext{
${ }^{11} \mathrm{O}$ nome da criança foi omitido a fim de preservar a identidade do menor.
} 
apresentou teores muito menores de $\mathrm{Hg}$ nas amostras de cabelo, ao contrário do PNJ, mesmo sendo ecossistemas interligados. Como a população de Manaus tem, de uma forma geral, melhores condições econômicas, possui maior capacidade de escolha de produtos alimentícios fornecedores de proteínas, somando-se o fato de que grande parte deles são de origem nordestina e não Amazônica (Enes, 2005).

Conclui-se então, que o padrão de consumo de uma população sofre influência de aspectos culturais, nutricionais, sócio-econômicos e demográficos, tornando necessário uma contínua observação desses fatores e de seus mecanismos para o entendimento do amplo acervo de variações a que está sujeito o comportamento alimentar (Barreto \& Cyrillo, 2001).

No Brasil, padrões diversificados de consumo alimentar que caracterizam a população podem ser constatados analisando-se os dados referentes a POF 2002 - 2003 (Pesquisa de Orçamentos Familiares realizada pelo IBGE), por meio do relatório de Análise da Disponibilidade Domiciliar de Alimentos e do Estado Nutricional no Brasil, onde foram investigadas as quantidades adquiridas de alimentos e bebidas para consumo no domicílio, segundo as Grandes Regiões, as situações urbana e rural e as formas de obtenção monetárias e não-monetárias (IBGE, 2004).

Segundo dados levantados nesse estudo, para uma dieta de 1883,89 kcal por dia, a participação relativa de carne de peixe no total de calorias, determinada pela aquisição alimentar domiciliar para a região Norte, foi de 3,07\%. Já o consumo relativo à carne bovina e de frango, foi de $9,32 \%$. Contudo, perfis diferenciados da disponibilidade domiciliar de alimentos caracterizam as cinco grandes regiões do País. Assim, por exemplo, a participação da carne de peixe na Região Sul (0,23\% para uma dieta de $1983,53 \mathrm{kcal}$ por dia) é muito menor do que aquela observada na Região Norte $(3,07 \%)$. Essa observação se repetiu para as demais regiões do país.

Os valores obtidos nesta pesquisa (POF 2002 - 2003) refletem ainda a importância da carne de peixe como fonte protéica para a população da Região Norte, que se destaca também pelo maior percentual de despesa familiar com pescados frescos $(7,48 \%)$, muito acima das demais regiões.

Quando se subdivide a Região Norte, onde a ingestão de carne de peixe é maior, em áreas urbanas e rurais, o quadro não é diferente. Para uma dieta de 1659,95 kcal por dia, a participação relativa de carne de peixe no total de calorias para a área urbana foi de 2,11\% e 4,89\% para a área rural (para uma dieta de 2524,55 kcal por dia).

Nesse estudo, nota-se também, que o efeito do rendimento familiar é substancial sobre a maioria dos alimentos e grupos de alimentos. A participação de carne bovina e de frango na dieta, 
tende a aumentar de forma uniforme com o nível de rendimentos familiares. Contudo, padrão oposto de relação com os rendimentos são vistos para a carne de peixe, que apresenta tendência de declínio com o aumento do rendimento familiar.

Pode-se concluir, que práticas de alimentação são importantes determinantes das condições de saúde não somente na infância, como na vida adulta e estão fortemente condicionadas ao poder aquisitivo das famílias, do qual dependem a disponibilidade, a quantidade e a qualidade dos alimentos consumidos. E a avaliação do consumo alimentar e a análise de indicadores biológicos de exposição, em pesquisas destinadas a estabelecer condições de saúde torna-se necessária, pois permite caracterizar o nível de risco e a vulnerabilidade da população às deficiências nutricionais e à contaminação por elementos tóxicos, particularmente com relação ao $\mathrm{Hg}$, cujos teores em amostras de cabelo está diretamente relacionado com a ingestão de peixe. Ainda, adequar ou propor medidas de intervenção que garantam a saúde, particularmente no segmento da população pré-escolar, idade na qual a dieta constitui um dos fatores determinantes da velocidade de crescimento e desenvolvimento.

\subsection{Resultados dos elementos determinados pelo método de análise por ativação neutrônica (AAN)}

\subsubsection{Resultados das análises dos materiais de referência biológicos por AAN}

\section{Exatidão e precisão da metodologia}

A exatidão e precisão do método de AAN foram verificados por meio da análise dos materiais de referência Orchard Leaves (OL) (NIST SRM 1571), Tomato Leaves (TL) (NIST SRM $1573^{\mathrm{a}}$ ) e Oyster Tissue (OT) (NIST SRM 1566b). Na Tabela 38, encontram-se os resultados obtidos na análise desses materiais de referência, bem como os valores certificados e os respectivos valores dos limites de detecção, para cada elemento determinado. 
Tabela 38 . Resultados obtidos $\left(\mathrm{mg} \mathrm{kg}^{-1}\right)$ na análise dos materiais de referência por AAN $(\mathrm{n}=5)$

\begin{tabular}{|c|c|c|c|c|c|c|c|c|c|c|c|c|c|}
\hline \multirow[t]{2}{*}{ Elementos } & \multicolumn{2}{|c|}{$\begin{array}{l}\text { Tomato Leaves } \\
\text { (NIST SRM 1573 }{ }^{\mathrm{a}} \text { ) }\end{array}$} & \multicolumn{2}{|c|}{ DPR ER } & \multicolumn{2}{|c|}{$\begin{array}{l}\text { Orchard Leaves } \\
\text { (NIST SRM - 1571) }\end{array}$} & \multirow{2}{*}{$\begin{array}{c}\text { DPR } \\
\% \\
\%\end{array}$} & \multirow{2}{*}{$\begin{array}{l}\text { ER } \\
\%\end{array}$} & \multicolumn{2}{|c|}{$\begin{array}{c}\text { Oyster Tissue } \\
\text { (NIST SRM 1566b) }\end{array}$} & \multicolumn{2}{|c|}{ DPR ER } & \multirow[t]{2}{*}{$\begin{array}{c}\mathrm{LD}^{\star} \\
\left(\mathrm{m} \mathrm{kg}^{-1}\right)\end{array}$} \\
\hline & Determ. & Certif. & $\%$ & $\%$ & Determ. & Certif. & & & Determ. & Certif. & $\%$ & $\%$ & \\
\hline $\mathrm{Ca}$ & $51306 \pm 700$ & $50500 \pm 900$ & 1,4 & 1,6 & $20144 \pm 925$ & $20900 \pm 300$ & 4,6 & 3,6 & $848 \pm 72$ & $838 \pm 20$ & 8,5 & 1,2 & 76 \\
\hline $\mathrm{Fe}$ & $347 \pm 5$ & $368 \pm 7$ & 1,4 & 5,7 & $298 \pm 8$ & $300 \pm 20$ & 2,7 & 0,7 & $210,2 \pm 10,9$ & $205,8 \pm 6,8$ & 5,2 & 2,1 & 1,05 \\
\hline $\mathbf{K}$ & $26596 \pm 450$ & $27000 \pm 500$ & 1,7 & 1,5 & $13656 \pm 531$ & $14700 \pm 300$ & 3,9 & 7,1 & $6390 \pm 496$ & $6520 \pm 300$ & 7,8 & 2,0 & 345 \\
\hline $\mathrm{Na}$ & $130 \pm 2$ & $136 \pm 4$ & 1,5 & 4,4 & $84 \pm 7$ & $82 \pm 6$ & 8,3 & 2,4 & $3411 \pm 311$ & $3297 \pm 50$ & 9,1 & 3,5 & 20,5 \\
\hline $\operatorname{Se}\left(\mu \mathrm{g} \mathrm{kg}^{-1}\right)$ & n.d. & $54 \pm 3$ & - & - & $85 \pm 6$ & $80 \pm 1$ & 7,0 & 6,2 & $2234 \pm 93$ & $2060 \pm 150$ & 4,2 & 8,4 & 65 \\
\hline Zn & $38,5 \pm 0,2$ & $39,7 \pm 0,7$ & 0,5 & 3,0 & $25 \pm 2$ & $25 \pm 3$ & 8,0 & 0,0 & $1491 \pm 102$ & $1424 \pm 46$ & 6,8 & 4,7 & 0,53 \\
\hline
\end{tabular}

n.d. - não determinado

As análises dos materiais de referência, pela técnica de AAN, na determinação dos elementos $\mathrm{Ca}, \mathrm{Fe}, \mathrm{K}, \mathrm{Na}$, Se e Zn, apresentaram desvios padrão relativos de 0,5 a 9,1\% e erros relativos de 0 a 8,4 \%, demonstrando assim, a precisão e a exatidão do método, respectivamente.

A Figura 29 mostra os valores de Z-score obtidos para os elementos analisados, que apresentam valores de concentração certificados nos materiais de referência Orchard Leaves (NIST 1571- OL), Tomato Leaves (NIST 1573a - TL) e Oyster Tissue (NIST SRM 1566b - OT).
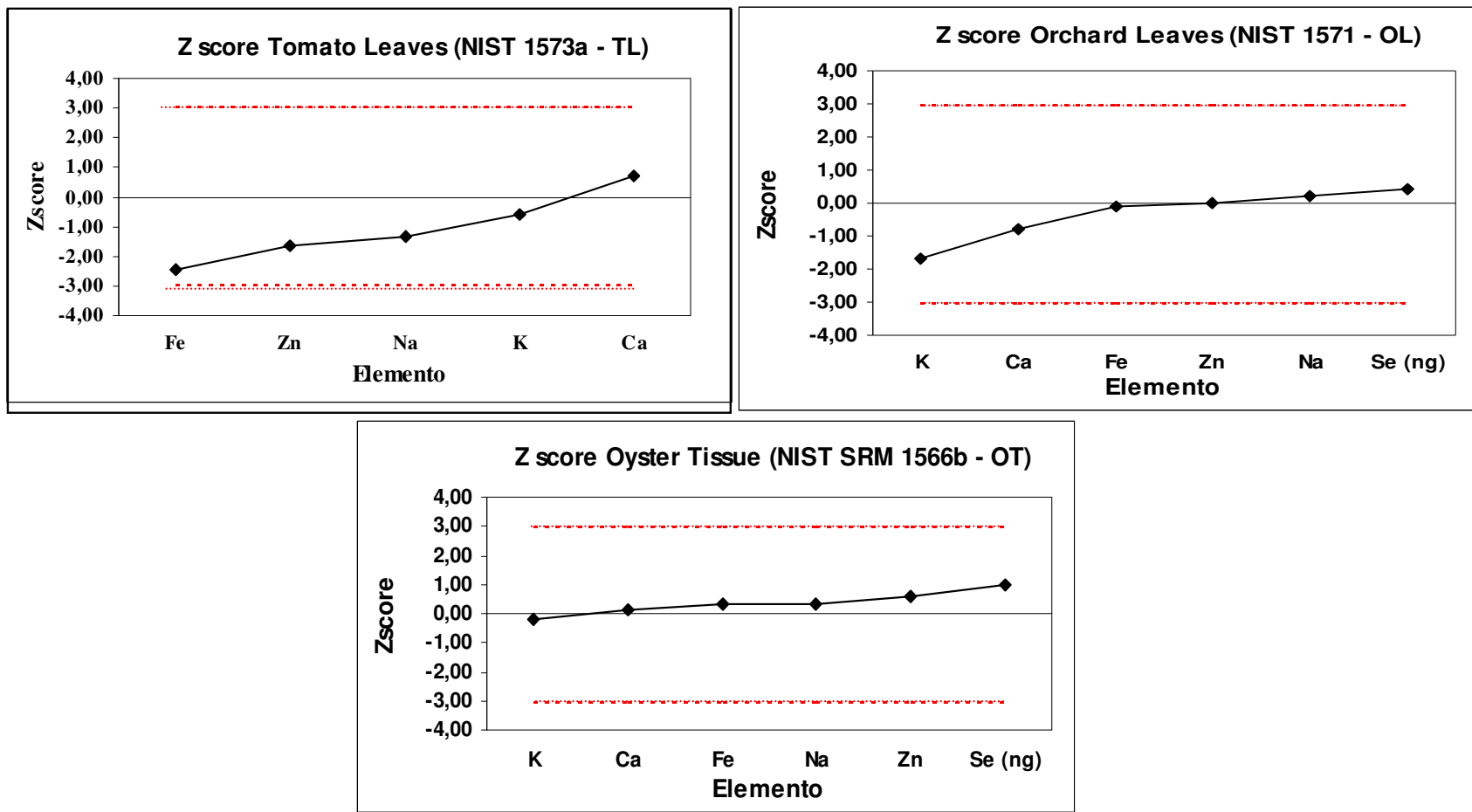

Figura 29. Carta de controle (valores de Z-score) para os elementos analisados, nos materiais de referências analisados por AAN. 
Pode-se observar que todos os valores de $\mathrm{Z}$ se encontram dentro do intervalo de -3 e +3 , indicando boa precisão e exatidão dos resultados obtidos.

Uma vez obtidas as melhores condições de análise pelo método por ativação neutrônica instrumental, conforme item 4.4 do capítulo 4, efetuaram-se as análises das dietas e dos peixes.

\subsubsection{Resultados das análises das dietas do PNJ e demais comunidades}

Na Tabela 39 são apresentados os valores dos teores obtidos nas análises das dietas, para a determinação dos elementos $\mathrm{Ca}, \mathrm{Fe}, \mathrm{K}, \mathrm{Na}$, Se e $\mathrm{Zn}$, de crianças do PNJ e comunidades próximas. As amostras foram analisadas em duplicata.

Tabela 39 . Resultados obtidos $\left(\mathrm{mg} \mathrm{kg}^{-1}\right)$ nas análises das dietas de pré-escolares de comunidades da região Amazônica, por AAN

\begin{tabular}{|c|c|c|c|c|c|c|c|}
\hline & Comunidades & $\mathbf{C a}$ & $\mathbf{F e}$ & $\mathbf{K}$ & $\mathbf{N a}$ & $\operatorname{Se}\left(\mu \mathrm{g} \mathrm{kg}^{-1}\right)$ & Zn \\
\hline \multirow{5}{*}{$\vec{z}$} & Cachoeira & $4047 \pm 250$ & $63 \pm 2$ & $5834 \pm 428$ & $9905 \pm 440$ & $249 \pm 16$ & $24 \pm 2$ \\
\hline & Jacaré & $8275 \pm 564$ & $62 \pm 4$ & $4829 \pm 747$ & $12631 \pm 481$ & $290 \pm 13$ & $29 \pm 6$ \\
\hline & Santa Elias & $576 \pm 89$ & $26 \pm 2$ & $5560 \pm 378$ & $3369 \pm 44$ & $278 \pm 16$ & $13 \pm 1$ \\
\hline & Seringalzinho & $2388 \pm 350$ & $41 \pm 10$ & $3646 \pm 892$ & $5940 \pm 894$ & $1859 \pm 68$ & $15 \pm 1$ \\
\hline & Vista Alegre & $1141 \pm 144$ & $68 \pm 3$ & $12000 \pm 809$ & $14786 \pm 769$ & $212 \pm 15$ & $20,4 \pm 0,9$ \\
\hline \multirow{6}{*}{ 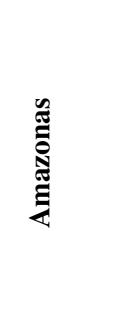 } & Alvarães & $1151 \pm 230$ & $29 \pm 2$ & $5032 \pm 357$ & $6812 \pm 291$ & $146 \pm 3$ & $17 \pm 1$ \\
\hline & Itapiranga & $1722 \pm 135$ & $26 \pm 1$ & $3143 \pm 68$ & $7448 \pm 45$ & $107 \pm 13$ & $14 \pm 1$ \\
\hline & Nhamundá & n.d. & $35 \pm 3$ & $4347 \pm 345$ & $8198 \pm 369$ & $151 \pm 9$ & $16 \pm 1$ \\
\hline & Nogueira & n.d. & $35 \pm 2$ & $4957 \pm 82$ & $5172 \pm 483$ & $144 \pm 7$ & $14 \pm 1$ \\
\hline & Novo Airão & $1195 \pm 98$ & $58 \pm 3$ & $5861 \pm 236$ & $7823 \pm 567$ & $176 \pm 14$ & $21 \pm 2$ \\
\hline & Urucurituba & $1334 \pm 87$ & $28 \pm 1$ & $5690 \pm 231$ & $3423 \pm 98$ & $85 \pm 4$ & $16 \pm 1$ \\
\hline Manaus & SESI & $1295 \pm 210$ & $37 \pm 2$ & $4566 \pm 134$ & $8029 \pm 123$ & $89 \pm 9$ & $38 \pm 3$ \\
\hline
\end{tabular}

n.d. - não determinado

Observou-se uma grande variação de concentração para os elementos essenciais: $\mathrm{Ca}\left(576\right.$ a $\left.8275 \mathrm{mg} \mathrm{kg}^{-1}\right), \mathrm{Fe}\left(26\right.$ a $\left.68 \mathrm{mg} \mathrm{kg}^{-1}\right), \mathrm{K}\left(3143\right.$ a $\left.12000 \mathrm{mg} \mathrm{kg}^{-1}\right), \mathrm{Na}$ (3369 a $\left.14786 \mathrm{mg} \mathrm{kg}^{-1}\right)$, Se (85 a $\left.1869 \mathrm{mg} \mathrm{kg}^{-1}\right)$ e $\mathrm{Zn}\left(13\right.$ a $\left.38 \mathrm{mg} \mathrm{kg}^{-1}\right)$, nas dietas analisadas. Verificou-se 
uma maior concentração de Se na dieta da comunidade Serigalzinho, pertencente ao PNJ, quando comparadas às demais comunidades.

A partir dos valores de concentração em peso seco (Tabela 39) e do consumo médio diário para cada criança (em média de $150 \mathrm{~g}$ de dieta seca por dia) (Tabela 16), foi possível calcular a ingestão diária para cada elemento analisado (Tabela 40). Também são apresentados os valores tabelados de EAR (Recomendação Média Estimada) para crianças em idade pré-escolar (4 - 8 anos) e os valores de AI (Ingestão Adequada) para adultos, para os elementos que ainda não possuem valores EAR.

Tabela 40 . Ingestão diária de elementos essenciais de pré-escolares do Parque Nacional do Jaú (PNJ), Ingestão média (mg/dia) e os valores de EAR e AI

\begin{tabular}{|c|c|c|c|c|c|c|c|}
\hline & Comunidades & $\mathrm{Ca}$ & $\mathrm{Fe}$ & $\mathbf{K}$ & $\mathrm{Na}$ & $\operatorname{Se}\left(\mu \mathrm{g} \mathrm{kg}^{-1}\right)$ & $\mathbf{Z n}$ \\
\hline \multirow{5}{*}{$\bar{Z}$} & Cachoeira & 192 & 3 & 277 & 470 & 12 & 1 \\
\hline & Jacaré & 1505 & 11,2 & 974 & 2297 & 54 & 5 \\
\hline & Santa Elias & 117 & 7 & 1235 & 1522 & 22 & 2 \\
\hline & Seringalzinho & 320 & 6,7 & 1642 & 664 & 33 & 2 \\
\hline & Vista Alegre & 58 & 2,6 & 559 & 339 & 28 & 3 \\
\hline \multirow{6}{*}{ 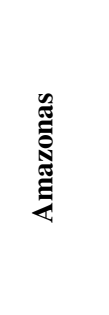 } & Alvarães & 70 & 1,8 & 308 & 417 & 8,9 & 1,1 \\
\hline & Itapiranga & 263 & 4 & 480 & 1137 & 16 & 2,1 \\
\hline & Nhamundá & - & 6,5 & 802 & 1513 & 28 & 3,4 \\
\hline & Nogueira & - & 5,2 & 736 & 768 & 21 & 2,2 \\
\hline & Novo Airão & 117 & 5,7 & 572 & 763 & 17 & 2,1 \\
\hline & Urucurituba & 134 & 2,8 & 573 & 344 & 9 & 1,6 \\
\hline \multirow[t]{4}{*}{ Manaus } & SESI & 377 & 10,7 & 1330 & 2339 & 26 & 11,1 \\
\hline & $\operatorname{EAR}^{\mathrm{a}}(\mathrm{mg} / \mathrm{dia})$ & - & 4,1 & & & $23(\mu \mathrm{g} / \mathrm{dia})$ & 4,0 \\
\hline & $\mathrm{AI}^{\mathrm{b}}(\mathrm{mg} / \mathrm{dia})$ & 800 & & $3000^{*}$ & $1000^{*}$ & 30 ( $\mu \mathrm{g} / \mathrm{dia})$ & 5,0 \\
\hline & & & & $3800^{\star \star}$ & $1200^{\star *}$ & & \\
\hline
\end{tabular}

${ }^{a}$ EAR (Recomendação Média Estimada) para crianças em idade pré-escolar (4-8 anos) e AI (Ingestão Adequada) para adultos.

${ }^{\mathrm{b}}$ Crianças de 1-3 anos (AI para Na e K); ** Crianças de 4-8 anos (AI para Na e K) (DRI, 2004b). 


\subsubsection{Verificação da adequação das dietas em relação aos micronutrientes Ca, Fe, K, Na, Se e Zn}

\section{Cálcio}

Sabe-se que o organismo humano necessita de cálcio ao longo de toda existência, especialmente em três períodos da vida que são críticos: infância, gestação/lactação e na menopausa. Nestas fases da vida torna-se importante uma quantidade adequada de cálcio na dieta para manter uma boa mineralização óssea. Ele também é importante, por exemplo, para uma adequada contração dos músculos, transmissão dos impulsos nervosos, função hormonal, além de ser importante para a manutenção da pressão arterial. As principais fontes de cálcio são: leite e derivados, folhas e peixes.

De acordo com a literatura, vários fatores podem afetar a absorção do cálcio, entre eles a interação nutriente-nutriente. Como exemplo, podemos citar a excreção do sódio e cálcio pelos rins. A alta ingestão de cloreto de sódio (sal de cozinha) resulta em um aumento na absorção e eliminação de sódio, juntamente com um aumento da eliminação do cálcio. Em crianças e adolescentes, sódio na urina é um indicador importante da eliminação renal do elemento, apesar de uma relação entre a ingestão de sal e desenvolvimento ósseo ainda não ter sido comprovada (DRI, 2003).

Ainda não foi estabelecido um critério para ingestão de cálcio para crianças, que reflita uma resposta real da ingestão diária, deste modo, a ingestão recomendada para o cálcio está baseada em uma ingestão adequada (AI) que reflete a ingestão média derivada principalmente pela ingestão de leite humano.

Os valores obtidos neste estudo (58 a $320 \mathrm{mg} / \mathrm{dia}$ ) estão abaixo do recomendado como meta de ingestão alimentar de indivíduos saudáveis nesta idade, quando comparados ao valor de AI para crianças (800 mg/dia). Somente para a população de Jacaré, o valor obtido ficou acima do esperado, $1505 \mathrm{mg} /$ dia, indicando uma possível utilização de ovos de quelônios, muito consumidos nas comunidades do PNJ, no preparo dos alimentos (Pezzuti, 2003) ${ }^{12}$.

${ }^{12}$ A utilização de quelônios e seus ovos na dieta alimentar da região é antiga. As populações ameríndias se interessavam pela carne e pelos ovos in natura para uso alimentar e com a chegada dos portugueses, passou-se também a se utilizar os ovos de tartaruga para retirada do óleo. Para se obter o óleo quebram-se milhares de ovos no casco de uma canoa, sendo batidos e remexidos com o remo, até que se forme uma mistura onde a gordura que se destaca é retirada e colocada em grandes almofarizes para purificação e redução (Salati e col., 1998). 
A ingestão média para o cálcio foi de $183 \mathrm{mg} /$ dia excluindo-se a dieta de Jacaré, sendo que apenas $8,3 \%$ das dietas mostravam prevalência de adequação com relação a este elemento, quando a ingestão é comparada ao valor de AI . Estes valores podem ser explicados, em parte, pelo baixo consumo diário de produtos lácteos pela população.

No Brasil, investigações relativas à ingestão de cálcio por crianças e adolescentes de diferentes regiões não indicam resultados otimistas e, em geral, a alimentação brasileira é deficiente neste mineral, com resultados que variam de 250 a 500 mg/dia (Favaro e col., 1997). No município de Maceió, Albuquerque \& Monteiro (2002) estimaram a ingestão de nutrientes, em um grupo de 247 escolares, com idade média de 9,5 anos. Os resultados demonstraram que não foram alcançadas as recomendações para ingestão de cálcio propostas pela DRI, sendo que a ingestão média foi de apenas $339 \mathrm{mg} / \mathrm{dia}$ para os meninos e $351 \mathrm{mg} / \mathrm{dia}$ para as meninas. Lerner e col. (2000) avaliaram o consumo de cálcio em 323 adolescentes, de ambos os sexos, entre as idades de 13 e 14 anos, na cidade de Osasco. Os autores encontraram uma ingestão superior de cálcio comparada àquela apresentada no estudo anterior, com média de ingestão de $600 \mathrm{mg} / \mathrm{dia}$, mas ainda distante das recomendações para adolescentes.

\section{Ferro}

A deficiência de ferro é uma das principais deficiências de micronutrientes no mundo e afeta milhões de indivíduos durante todo ciclo de vida, em especial as lactantes, crianças e mulheres grávidas. A reduzida disponibilidade de ferro, seja por ingestão insuficiente ou por comprometimento na absorção, pode resultar na ocorrência de anemia, considerada um sério problema de saúde pública no Brasil. A anemia ferropriva é uma das enfermidades mais prevalentes em todo o mundo, particularmente nos países em desenvolvimento, sendo a deficiência de ferro a causa mais importante dessa carência. Lactentes, pré-escolares, adolescentes e gestantes são os grupos de risco mais susceptíveis à anemia ferropriva, pelo aumento das necessidades de ferro decorrentes da rápida expansão dos tecidos e da massa de hemácias (Garcia e col., 1998). As principais conseqüências da anemia para a saúde são alterações de crescimento, pele e mucosas, sistema digestório, função muscular, comportamento, imunidade e aumento da mortalidade e susceptibilidade às infecções em crianças acometidas por anemia grave (Vannucchi e col., 1992). Para o Brasil, na Região Norte, em Manaus, merecem atenção os trabalhos com pré-escolares, na área ribeirinha dos rios Solimões e Negro, realizados por Giugliano e col. (1978) e Yuyama e col. (2000), que detectaram anemia ferropriva nos grupos estudados. A presença dessa doença pode ser 
explicada, em parte, pela monotonia alimentar, registrada no Estudo Nacional de Despesa Familiar (ENDEF), realizado entre 1974 e 1975 (IBGE, 1977), no qual se observa um elenco de apenas sete alimentos (mandioca, trigo, arroz, açúcar, gordura, feijão e milho) respondendo por setenta e cinco por cento das calorias diárias ingeridas pela população amazônica (Carvalho, 1989). A tendência do consumo de feijão, considerado uma importante fonte de ferro para a população brasileira, constatada a partir da análise dos inquéritos realizados pelo IBGE nas décadas de 70, 80, 90 e da mais recentes pesquisas de orçamentos familiares, revela ainda, uma queda de $37 \%$ do consumo dessa leguminosa em um período de 30 anos, o que pode agravar o quadro de anemia entre a população (IBGE, 2004).

A deficiência de ferro na dieta tem sido relatada em diversos estudos envolvendo préescolares albergados em creches, como os de Mazzili (1987) e Sichieri et al. (1988). Faganello (2002), analisando os dados da POF 1995-1996 referentes às famílias das regiões metropolitanas de São Paulo e Recife, verificou uma disponibilidade menor (no âmbito dos domicílios) de alguns minerais, dentre eles o ferro. Estudo realizado por Garcia e col. (2003) envolvendo adolescentes de um centro de Juventude de São Paulo, também destacou o consumo insuficiente de ferro, com prevalência de inadequação de $59,8 \%$ e $83,6 \%$ entre meninos e meninas, respectivamente.

No presente estudo, comparando-se os valores de ingestão diária para o Ferro, que variaram de 1,8 a 11,2 mg/dia, com os valores EAR para crianças (4 a 8 anos), constatou-se que $75 \%$ das dietas atingiram valores adequados de acordo com o valor EAR (4,1 mg/dia) (DRI, 2000a). Já que a EAR determina uma ingestão de nutrientes que se estima atender a recomendação de $50 \%$ dos indivíduos de um grupo, podemos observar que os valores exigidos pela EAR estão sendo atingidos no caso destas comunidades, entretanto, $25 \%$ das dietas analisadas ainda não atingiram o valor preconizado.

\section{Potássio}

Principal cátion do fluido intracelular, está presente em pequenas quantidades no fluido extracelular. Participa da manutenção do equilíbrio hídrico normal, assim como o sódio. Juntamente com o cálcio, o potássio é importante na regulação da atividade neuromuscular e promove o crescimento celular (Whitmire, 2002). Segundo Tucker e col. (1999), o potássio e o magnésio (associado ao consumo de frutas e vegetais) podem promover aumento da densidade mineral dos ossos em homens e mulheres idosos, suscetíveis à osteoporose. Tal afirmação decorre do fato desses minerais aumentarem a absorção de cálcio no organismo. Normalmente, o potássio ingerido na 
dieta é excretado pelos rins (Weldy, 1973) e as frutas e os vegetais, contribuem com mais da metade do potássio consumido pela população (Tucker, 1999). As necessidades de potássio são maiores em período de crescimento e fora dele são mínimas, sendo geralmente cobertas pela alimentação corrente.

Geralmente não há deficiência de potássio devido a ingestão inadequada em indivíduos saudáveis, uma vez que o elemento se encontra amplamente distribuído nos alimentos. Contudo, no Brasil, analisando-se a disponibilidade de micronutrientes para as famílias moradoras das áreas rurais e urbanas das Regiões Norte e Sul (dados da POF 2002-2003), apud (Enes, 2005), foi possível verificar, de uma forma geral, uma baixa disponibilidade de potássio para as famílias, no âmbito do domicílio, para o qual a disponibilidade média observada não alcança, por exemplo, as recomendações nutrionais recomendadas para um indivíduo adulto.

A necessidade de potássio foi avaliada em poucos estudos, mas a princípio recomendava-se uma ingestão mínima de 1000 a 3800 mg/dia, para crianças de 1 a 8 anos (National Research Council, 1989). Recentemente a AI (Ingestão Adequada) foi determinada para crianças: 3000 mg/dia (1-3 anos) e 3800 mg/dia (4-8 anos) (DRI, 2004); esta quantidade garante níveis mais baixos de pressão sangüínea, redução dos efeitos adversos da ingestão sódio/cloro e diminuição da possibilidade de perda óssea (DRI, 2004). Verificando-se os resultados obtidos (entre 277 e 1642 $\mathrm{mg} / \mathrm{dia}$ ) podemos observar que nenhuma dieta atingiu as novas recomendações.

\section{Sódio}

Íon predominante do líquido extracelular, regula o tamanho desse compartimento, bem como o volume do plasma sangüíneo. Também auxilia na condução de impulsos nervosos e no controle da contração muscular (Whitmire, 2002). Ingressa no organismo através dos alimentos e é deliberadamente acrescentado à dieta com o sal de cozinha (Franco, 1992).

Embora seja aceito que o sódio seja essencial a vida humana, não há concordância quanto à necessidade mínima diária. Estimava-se, que a ingestão total diária de 120-400 mg deveria suprir as necessidades de crianças e $500 \mathrm{mg}$ para adultos (National Research Council, 1989). Recentemente a AI para o sódio foi determinada para crianças: $1000 \mathrm{mg} / \mathrm{dia}(1-3$ anos) e $1200 \mathrm{mg} / \mathrm{dia}$ (4-8 anos) (DRI, 2004); este valor garante que a dieta está fornecendo a quantidade adequada do elemento. As necessidades de sódio são mínimas e largamente cobertas pela alimentação. Além disso, os rins são capazes de reabsorver praticamente todo o sódio filtrado anteriormente. Não há aumento das 
necessidades, mesmo em caso de forte calor ou de atividades esportivas de alto nível, ou ainda no exercício de certas profissões (caldeiraria, minas). No presente trabalho, $42 \%$ das dietas atingiram o valor preconizado.

\section{Selênio}

O selênio é um oligoelemento essencial à saúde. No caso de doenças crônicas como a aterosclerose, câncer, artrite, cirrose e efisema, há fortes indícios de que ele atue como elemento protetor. Por muitos anos, o selênio foi considerado tóxico para animais, quando ingerido em altas doses, mas recentemente descobriu-se que em quantidades muito pequenas ele é necessário na dieta. O selênio se encontra naturalmente nos alimentos de origem animal, frutos do mar, carnes, fígado, rim, vegetais e cereais integrais, sendo a castanha-do-Brasil ${ }^{13} \mathrm{o}$ alimento mais rico neste mineral. A maior parte do selênio no tecido animal está presente em quantidades variadas na forma de selenometionina ou selenocisteína, as quais são chamadas selenoproteínas. Algumas das funções conhecidas do selênio (através da associação com proteínas) incluem a proteção contra o estresse oxidativo, regulação da ação do hormônio da tireóide, regulação do estado redox da vitamina $\mathrm{C}$ e hepato-protetor com relação a contaminação por Hg (DRI, 2000b).

O teor de selênio no solo pode se refletir nas plantas. É bem conhecido o fato de que há, no globo terrestre, algumas faixas onde a concentração deste elemento é tão elevada a ponto de causar intoxicação em animais que consomem pastagens ali cultivadas, como por exemplo, em certas planícies do Canadá e em alguns estados dos Estados Unidos, como Nebraska, Dakota, Utah e Wyoming (Reilli, 1996). Na China, há regiões onde o teor de selênio é excessivamente elevado, a ponto de causar intoxicação (Levander, 1997), e outras onde é tão baixo a ponto de causar problemas por deficiência (Silva \& Williams, 1993).

Chang e col. (1995), afirmam que cerca de 0,5 a $1,0 \mu \mathrm{g} / \mathrm{kg} /$ peso de selênio na dieta é suficiente para os requerimentos dietéticos em humanos. Estudos recentes têm mostrado que a inclusão de castanha-do-Brasil na dieta de ratos que receberam administração intragástrica do carcinógeno mamário, dimetilbenzen(a)antracene (DMBA), reduziu o número de tumores acima de $72,7 \%$. A castanha-do-Brasil é naturalmente muito rica em selênio e a proteção contra a formação de tumor foi creditada ao alto conteúdo deste elemento. Quando a amêndoa da planta nogueira

\footnotetext{
${ }^{13}$ Nome científico: Bertholletia excelsa H.B.K.
} 
substituiu a castanha-do-Brasil em dietas controle, nenhuma redução significativa na formação de tumor foi verificada (Lisk, 1999).

$\mathrm{Na}$ disponibilidade de micronutrientes para as famílias moradoras das áreas rurais e urbanas das Regiões Norte e Sul (dados da POF 2002-2003), apud (Enes, 2005), também foi possível verificar, de uma forma geral, uma baixa disponibilidade de selênio, ficando o valor abaixo do recomendado para indivíduos adultos para as áreas urbanas das duas regiões analisadas, o que sugere possível influência da alimentação fora do domicílio, que é freqüentemente mais comum entre a população dos centros urbanos.

Os valores de ingestão diária obtidos para o selênio variaram de 8,9 a $54 \mu \mathrm{g} / \mathrm{dia}$. Comparando-se estes valores aos valores de EAR de acordo com a nova recomendação para crianças (4 a 8 anos), constatou-se que $42 \%$ das dietas atingiram valores adequados de acordo com o valor EAR ( $23 \mu \mathrm{g} / \mathrm{dia})$. Duas comunidades, Jacaré e Serigalzinho, ambas pertencentes ao PNJ, ultrapassaram o valor de AI recomendado para este estágio de vida.

\section{Zinco}

O zinco é essencial para alguns microorganismos, plantas e animais e sua deficiência pode impedir o crescimento e o desenvolvimento. Este elemento está amplamente distribuído na alimentação, mas sua biodiponibilidade está em função dos demais componentes presentes no processo da digestão, pois normalmente não se encontra presente na forma de íon livre. Como um componente estrutural e/ou funcional de várias metaloenzimas e metaloproteínas, o zinco participa de muitas reações do metabolismo celular, incluindo processos fisiológicos, tais como função imune, defesa antioxidante, crescimento e desenvolvimento (Szckurek e col., 2001).

Os alimentos diferem no seu conteúdo de Zn, variando de 0,002 mg/100g de clara de ovo, $1 \mathrm{mg} / 100 \mathrm{~g}$ de frango até $75 \mathrm{mg} / 100 \mathrm{~g}$ de ostras. Mariscos, ostras, carnes vermelhas, fígado, miúdos e ovos são consideradas as melhores fontes de zinco. Nozes e leguminosas são fontes relativamente boas do elemento. O consumo de zinco é influenciado pela fonte protéica da dieta, assim, dietas constituídas de ovos, leite, frango e peixe têm menor razão Zn:proteína do que aquelas de mariscos, ostras e carnes vermelhas (Sandström, 1997).

A deficiência de zinco grave e moderada, tem sido cada vez mais detectada, principalmente nos países em desenvolvimento, onde estudos bem delineados têm mostrado a importância clínica deste estado de deficiência, onde se observa: retardo no crescimento, diarréia, pneumonia, malária e 
desenvolvimento cerebral prejudicado (Hambidge, 2000). Trabalhos têm mostrado que crianças suplementadas com zinco têm menor incidência de diarréia, pneumonia e malária, quando comparadas com crianças que não recebem zinco (Black \& Sazawal, 2001; Strand e col., 2002).

Analisando-se os resultados obtidos para o zinco no presente estudo (de 1,0 a 11,1 mg/dia) verificou-se que para ambas as recomendações EAR (4,0 mg/dia) e AI (5,0 mg/dia) (DRI, 2000a), os valores de adequação foram atingidos em somente $17 \%$ das dietas.

\subsection{Resultados e adequação das dietas analisadas em relação a proteínas, lipídeos e carboidratos}

A alimentação é um componente fundamental para se ter uma boa qualidade de vida, a qual deve ser feita de maneira balanceada e diversificada, a fim de garantir a manutenção das atividades metabólicas do organismo. Assim sendo, a quantidade de alimentos deve ser suficiente para cobrir as exigências energéticas do organismo, mantendo seu balanço em equilíbrio; o regime alimentar deve ser completo em sua composição, garantindo ao organismo todas as substâncias que o integram e as quantidades dos diversos nutrientes que compõem a alimentação devem possuir uma relação de proporção entre si.

Nas Tabelas 41 e 42, são mostradas as composições centesimais médias determinadas nas dietas das crianças do PNJ e comunidades da região Amazônica avaliadas neste estudo. O valor de energia foi calculado a partir de teores das frações de proteínas, lipídeos e carboidratos, utilizandose os coeficientes específicos que levam em consideração os calores de combustão 4, 9 e 4 kcal, respectivamente. Conforme se pode observar, as necessidades calóricas não foram alcançadas. 
Tabela 41 - Composição centesimal e adequação das dietas das crianças das comunidades do PNJ

\begin{tabular}{|c|c|c|c|c|c|c|}
\hline & Cachoeira & Jacaré & Santo Elias & Seringalzinho & Vista Alegre & \\
\hline Componentes da dieta & $\underset{(1)}{\text { Total diário }}$ & Total diário & Total diário & Total diário & Total diário & Recomendações \\
\hline Energia (Kcal) ${ }^{(3)}$ & 203,8 & 627,7 & 425,1 & 591,8 & 427,1 & 1692 \\
\hline Proteínas (g) & 8,2 & 30,5 & 19,8 & 27,5 & 23,4 & 19 (g/dia) \\
\hline Lipídeos (g) & 3,9 & 12,8 & 6,5 & 8,1 & 6,7 & - \\
\hline $\begin{array}{l}\text { Carboidratos (g) c/ } \\
\text { fração fibra (g) }\end{array}$ & 33,8 & 97,8 & 71,9 & 101,6 & 68,3 & 130 (g/dia) \\
\hline Umidade (\%) & 65,4 & 64,5 & 56,3 & 63,5 & 64,7 & - \\
\hline Cinzas (\%) & 1,1 & 1,3 & 1,0 & 1,2 & 1,5 & - \\
\hline
\end{tabular}

(1) Para uma ingestão média de $150 \mathrm{~g} /$ dia (peso seco).

(2) Valores EAR (Recomendação Média Estimada) para crianças em idade pré-escolar (4-8anos).

(3) Valor de energia calculado considerando a fração de carboidratos com a fração fibras juntos.

Tabela 42 - Composição centesimal e adequação das dietas das crianças de comunidades da região Amazônica

\begin{tabular}{|c|c|c|c|c|c|c|c|c|}
\hline & Alvarães & Itapiranga & Nhamundá & Nogueira & Novo Airão & SESI & Urucurituba & \\
\hline $\begin{array}{c}\text { Componentes da } \\
\text { dieta }\end{array}$ & $\begin{array}{c}\text { Total diário } \\
\text { (1) }\end{array}$ & $\begin{array}{c}\text { Total diário } \\
\text { (1) }\end{array}$ & $\underset{(1)}{\text { Total diário }}$ & $\underset{(1)}{\text { Total diário }}$ & Total diário & $\underset{(1)}{\text { Total diário }}$ & $\begin{array}{c}\text { Total diário } \\
\text { (1) }\end{array}$ & Recomendações \\
\hline Energia (Kcal) ${ }^{(3)}$ & 559,0 & 454,2 & 629,2 & 477,2 & 346,4 & 685,6 & 348,4 & 1692 \\
\hline Proteínas (g) & 14,6 & 13,2 & 19,0 & 16,8 & 10,8 & 19,4 & 9,2 & 19 (g/dia) \\
\hline Lipídeos (g) & 8,8 & 4,6 & 7,6 & 4,8 & 3,6 & 9,6 & 2,76 & - \\
\hline Umidade (\%) & 65 & 72,7 & 64,3 & 72 & 71 & 74,9 & 73,5 & - \\
\hline Cinzas (\%) & 1,1 & 0,9 & 1,1 & 0,9 & 0,9 & 1,3 & 0,9 & - \\
\hline
\end{tabular}

(1) Para uma ingestão média de $150 \mathrm{~g} /$ dia (peso seco).

(2) Valores EAR (Recomendação Média Estimada) para crianças em idade pré-escolar (4-8 anos).

(3) Valor de energia calculado considerando a fração de carboidratos com a fração fibras juntos.

Os dados obtidos (Tabela 41 e 42) demonstram que a ingestão de energia não alcançou a recomendação preconizada pela EAR, para o estágio de vida estudado, resultado de uma alimentação quantitativamente insuficiente, mesmo sendo este valor estipulado para crianças americanas e canadenses e, portanto, superestimado. As dietas das crianças apresentaram um déficit calórico, mesmo considerando a fração fibra junto com o carboidrato para o cálculo da energia total 
das dietas, cujo valor está superestimado. Isto demonstra que o problema dos pré-escolares no PNJ e demais localidades do Estado do Amazonas ainda é calórico e por conseguinte protéico, pois apesar de uma adequação aparente de proteínas, na deficiência de calorias, a proteína é desviada para fins energéticos em detrimento à função plástica. No Brasil, especialmente no Nordeste, o déficit energético sempre apareceu como um importante marcador dos problemas nutricionais (Lucena e col., 1964; Romani \& Amigo, 1986; Dantas \& Cozzolino, 1990; Albuquerque, 1993). É difícil concluir se esta deficiência aconteceu em decorrência de mudanças no comportamento alimentar, diminuição das necessidades energéticas desta população ou devido a fatores econômicos. O acesso a produtos industrializados no PNJ é extremamente difícil, com exceção de alguns poucos mantimentos, como por exemplo, bolacha água e sal e macarrão e a pouca utilização de óleo de adição (azeite). A monotonia do cardápio também pode ter contribuído para a baixa ingestão calórica. No entanto, pode-se dizer em relação a este aspecto, que a persistência deste déficit durante o período da infância poderá contribuir para um desempenho do crescimento linear menos favorável do que poderia ser em melhores circunstâncias de vida.

Observando-se os valores obtidos para a ingestão de proteínas, verificou-se que a ingestão deste macronutriente atingiu quase o dobro do valor da recomendação de 19 gramas/dia, para este estágio de vida, nas dietas das crianças das comunidades Jacaré e Seringalzinho, ficando abaixo na comunidade Cachoeira. Para as comunidades da região Amazônica, somente Nhamundá e SESI atingiram o valor recomendado. Os valores para carboidratos ficaram abaixo dos valores preconizados pela EAR (130 g/dia) (DRI, 2003), com exceção da dieta SESI (Manaus).

Em relação a estes valores, cabem aqui duas observações: a primeira, relativa à questão da associação entre a adequação da ingestão energética e protéica e a segunda, relativa ao significado da adaptação biológica a um alto consumo de proteína.

Conforme citado anteriormente, o processo de síntese e quebra das proteínas é sensível à carência energética e, por isso, o balanço energético é um marcador importante, o qual influencia a utilização da proteína dietética. Os valores expressando a baixa adequação energética encontrada sugerem, neste grupo, um possível prejuízo na utilização da proteína dietética, mesmo tendo a ingestão protéica excedido o valor recomendado em algumas comunidades. Além do mais, o fato do consumo de proteína estar acima do esperado para a idade, não implica necessariamente um estado ótimo de saúde e crescimento, pois já existem indícios de que uma ingestão excessiva deste nutriente pode estar relacionada a um aumento da excreção urinária de cálcio e conseqüente redução 
na velocidade de crescimento, conforme foi observado em recém nascidos de baixo peso (WHO, 1985; Waterlow, 1996).

\subsection{Resultados das análises dos peixes da cidade de Manaus}

O ambiente aquático é um dos componentes da natureza amazônica e a pesca, sobretudo, ocupa um lugar de destaque na economia regional. O peixe ainda é o sustentáculo da alimentação do homem na Amazônia brasileira.

Amiúde, escuta-se que a grande biodiversidade de peixes amazônicos poderia abastecer o mundo de proteínas. Calcula-se em 500.000 t/ano a produtividade total da ictiofauna amazônica. Cerca de 60.000 toneladas de peixes são desembarcadas em Manaus (AM) anualmente, sendo que cinco espécies são responsáveis por mais de $70 \%$ deste total, são elas: os Jaraquis, Curimatã, Tambaqui, Pacu e Matrinxã. Essa produção tem sido usada para o consumo local e também em outras regiões, no país e exterior. Entre cerca de 2000 espécies de peixes existentes nos rios amazônicos, aparecem no mercado de Manaus em torno de 40 espécies, das quais somente 8 a 10 possuem expressão econômica. Os produtos de pescado amazônicos exportados, ou são congelados inteiros ou em forma de filés, concentrando-se nas espécies de bagres (Relatório, 1998).

Sabe-se que a origem do pescado capturado e comercializado em Manaus é descentralizada, sendo proveniente de rios de municípios próximos. O mercado da capital é considerado mais conveniente e lucrativo que o do interior, pois nos municípios de origem, o pescado não tem mercado suficiente para absorver toda a produção ou o preço de venda do pescado nestes locais é muito baixo e não compensatório (Cardoso e col., 2004). Portanto, a avaliação da qualidade dos peixes comercializados em Manaus, do ponto de vista nutricional e químico pode contribuir para um maior conhecimento sobre a qualidade dos pecados da região.

Somando-se que no Amazonas, a realidade nutricional das populações ainda repercute de forma preocupante, pois de acordo com os indicadores utilizados, deixa implícito o debilitado estado geral de saúde e a triste realidade nutricional, social e econômica a que historicamente está submetida à população Amazônica. Desta forma, o consumo alimentar pode ser um indicador de grande importância, para o conhecimento da cadeia causal da desnutrição (YuYama e col., 1999); a determinação da composição dos alimentos, com relação aos macro e micronutrientes, é uma ferramenta relevante para se determinar a fonte adequada de ingestão dos nutrientes essenciais. 
Há poucas informações em relação aos constituintes nutricionais e químicos das espécies de peixes, principalmente após sofrerem algum processo de cocção. Dessa forma, considerando a relevância do monitoramento do consumo de alimentos em uma população, por meio de levantamentos periódicos como parte de um conjunto de medidas que fornecem informações para a análise diagnóstica sobre seu estado de saúde e nutrição, proporcionar dados reais sobre o consumo de nutrientes, principalmente quanto aos teores de micronutrientes e elementos tóxicos advindos da ingestão de peixes, auxiliam na avaliação do potencial nutritivo das espécies de peixes da região Amazônica, bem como, permitem o estabelecimento de dietas adequadas e quando necessário, propor programas de intervenção de acordo com as necessidades.

Na Tabela 43, anexo XX, são apresentados os valores dos teores obtidos nas análises dos peixes preparados sob diferentes formas de cocção, para os elementos $\mathrm{Ca}, \mathrm{Fe}, \mathrm{K}, \mathrm{Na}$, Se e Zn, da cidade de Manaus. As amostras foram analisadas em duplicata e optou-se por apresentar novamente os valores obtidos para o $\mathrm{Hg}$ total (em vermelho) visto a sua interação com outros elementos, particularmente o selênio, facilitando a interpretação dos resultados.

\section{Análise descritiva dos resultados}

Inicialmente avaliou-se os teores de $\mathrm{Ca}, \mathrm{Fe}, \mathrm{K}, \mathrm{Na}, \mathrm{Se}, \mathrm{Zn}$ e $\mathrm{Hg}$ nas amostras de peixe, em função do processo de cocção (Figuras 30 a 36). 


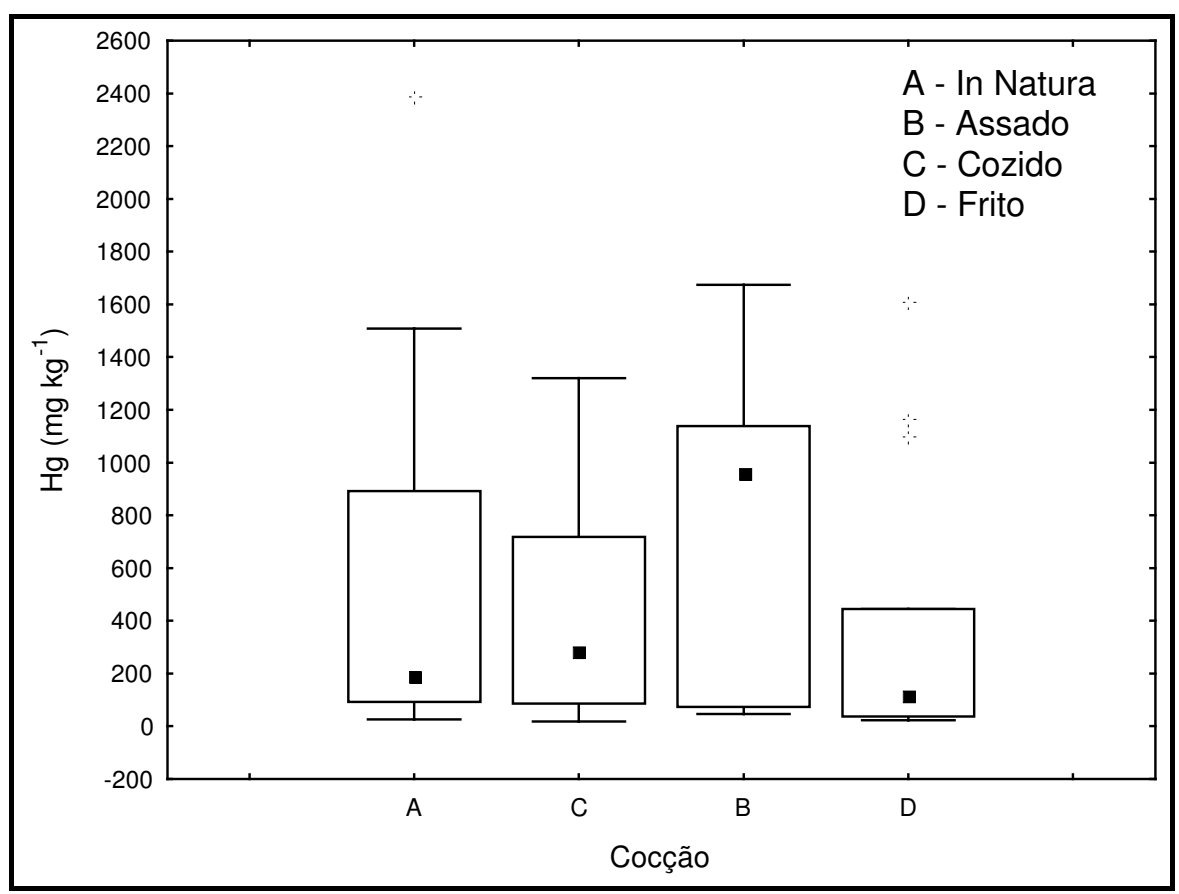

Figura 30. Box plot da variação do teor de $\mathrm{Hg}$ total nas amostras de peixe em função do processo de cocção.

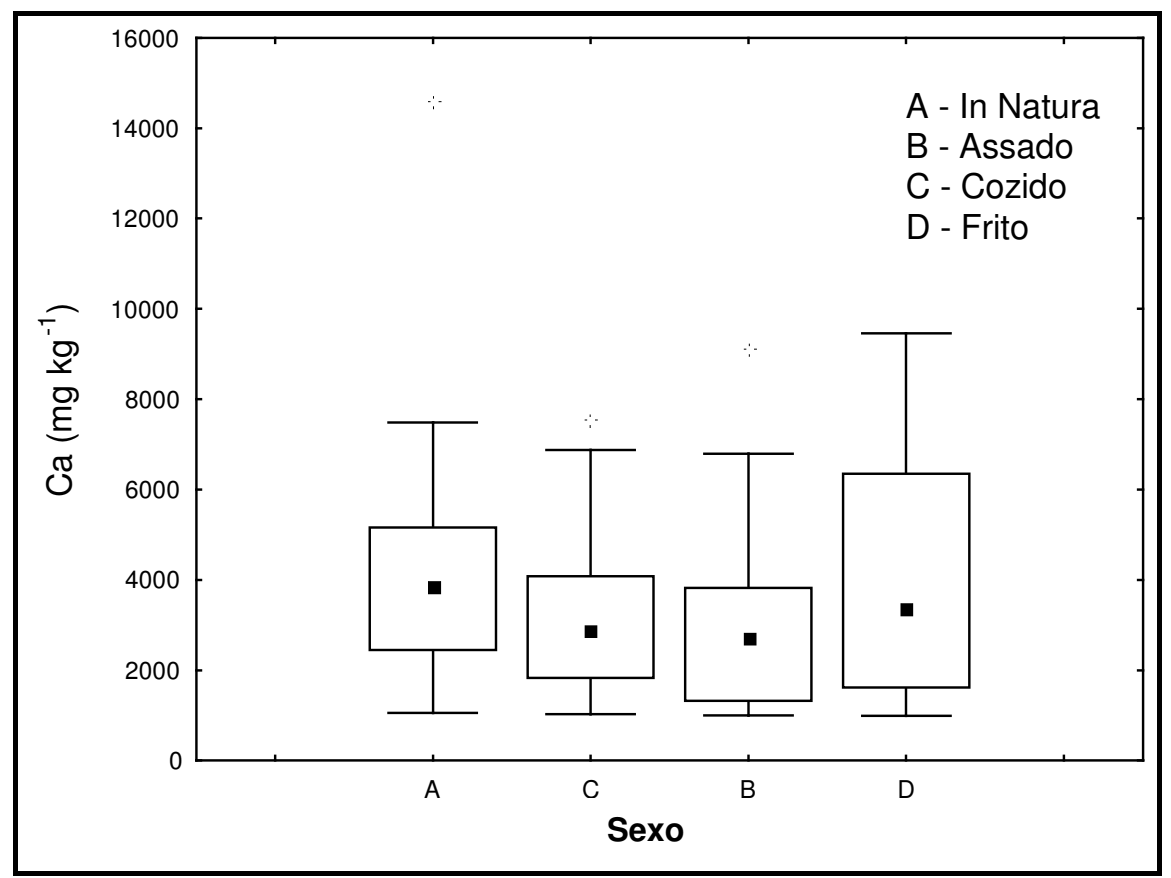

Figura 31. Boxplot da variação do teor de Ca nas amostras de peixe em função do processo de cocção. 


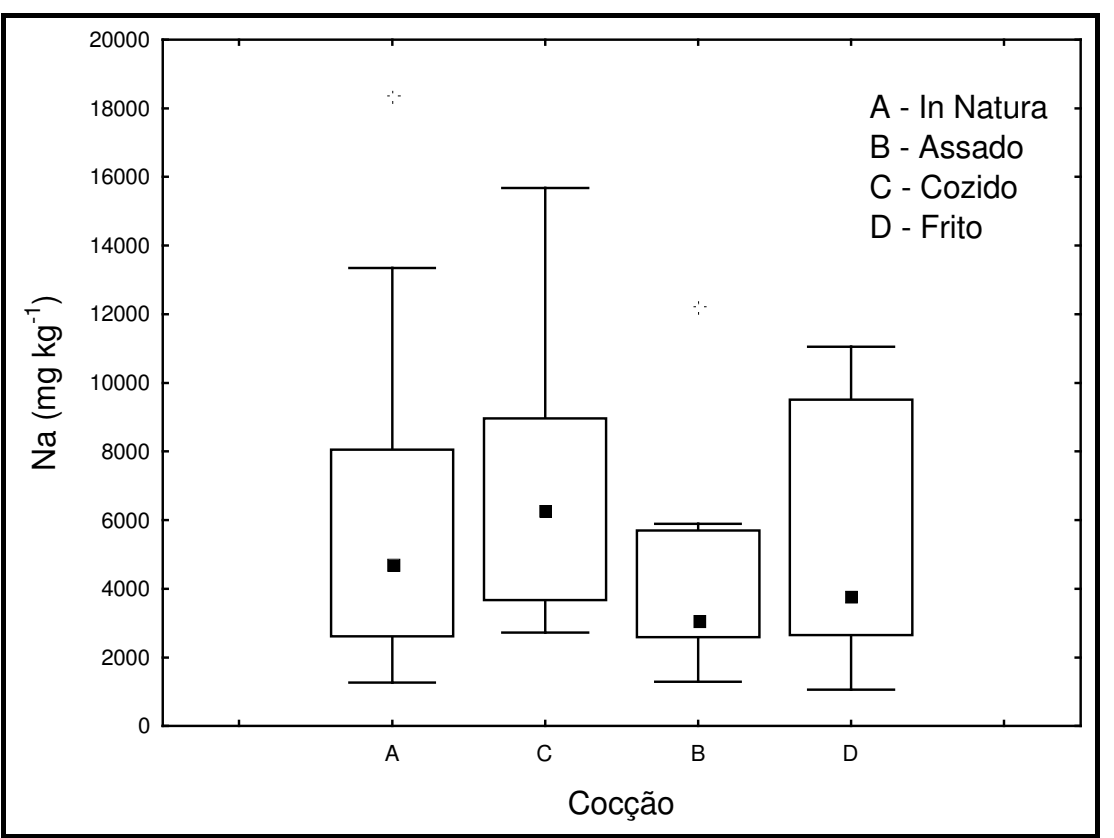

Figura 32. Boxplot da variação do teor de Na nas amostras de peixe em função do processo de cocção.

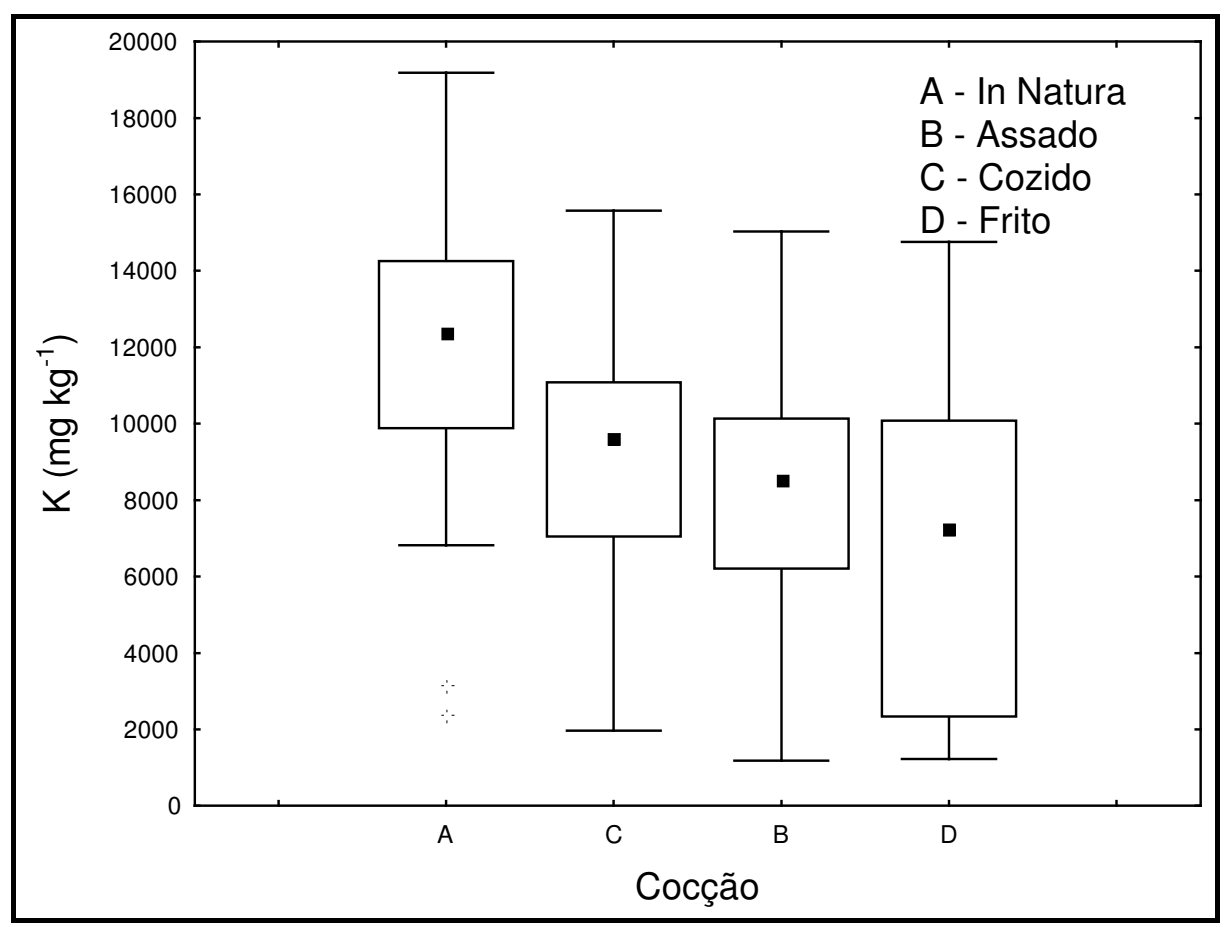

Figura 33. Boxplot da variação do teor de K nas amostras de peixe em função do processo de cocção. 


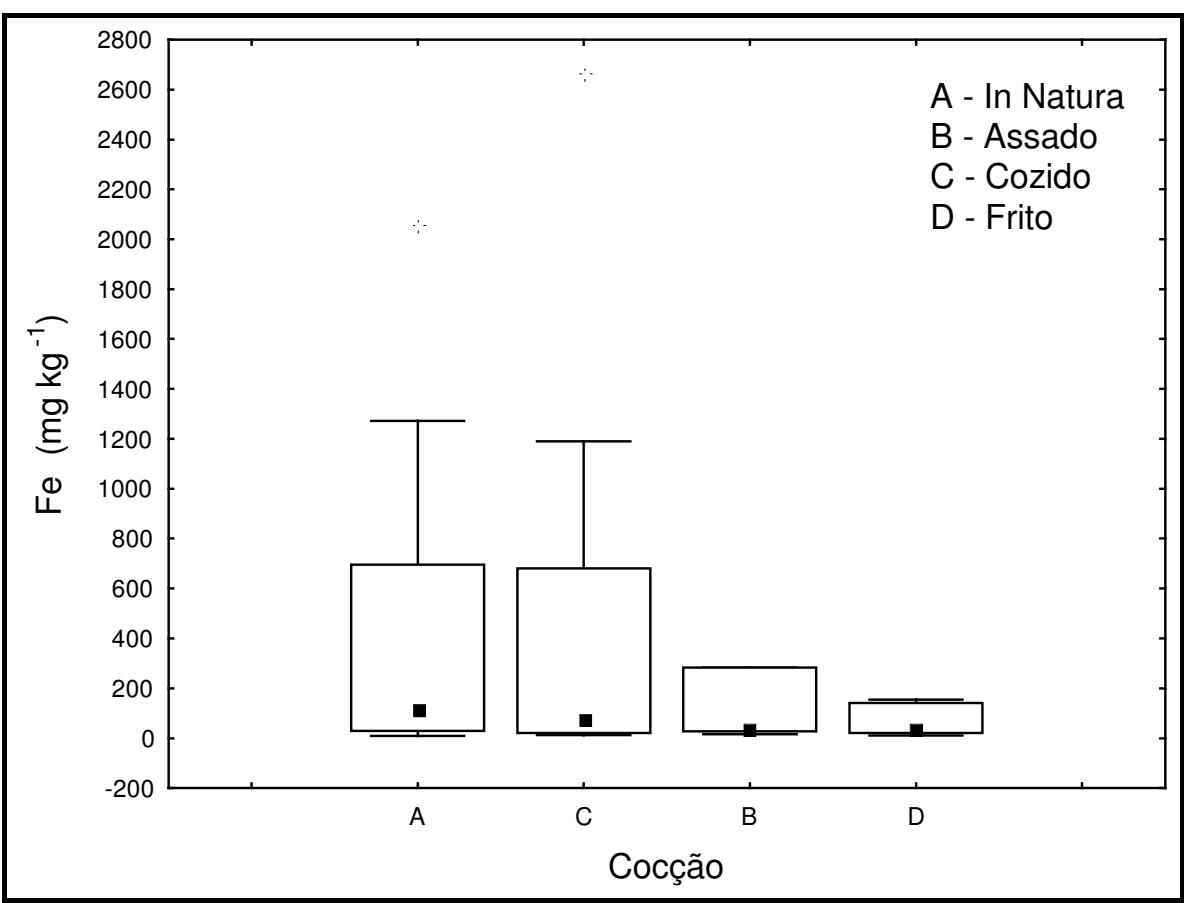

Figura 34. Box plot da variação do teor de Fe nas amostras de peixe em função do processo de cocção.

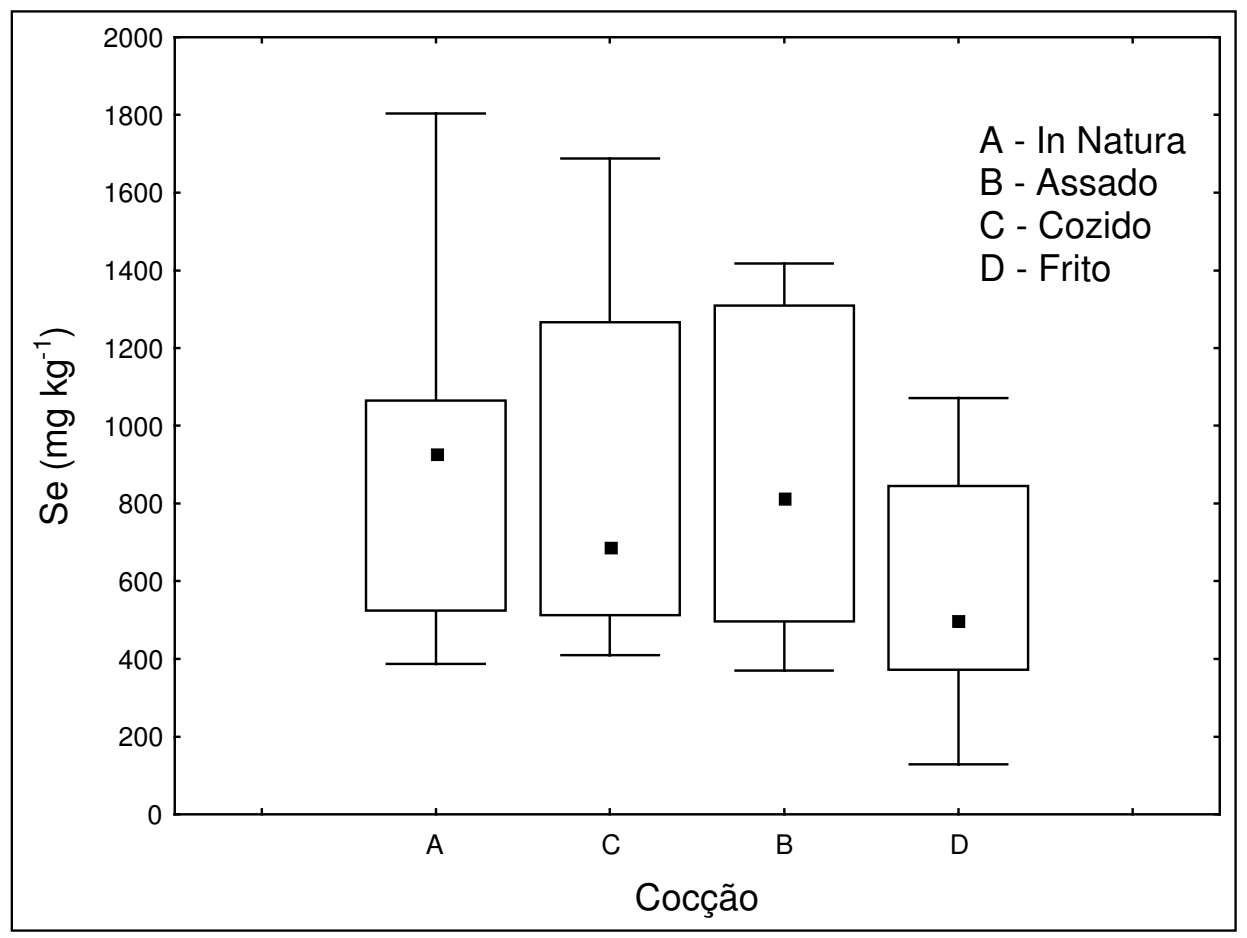

Figura 35. Box plot da variação do teor de Se nas amostras de peixe em função do processo de cocção. 


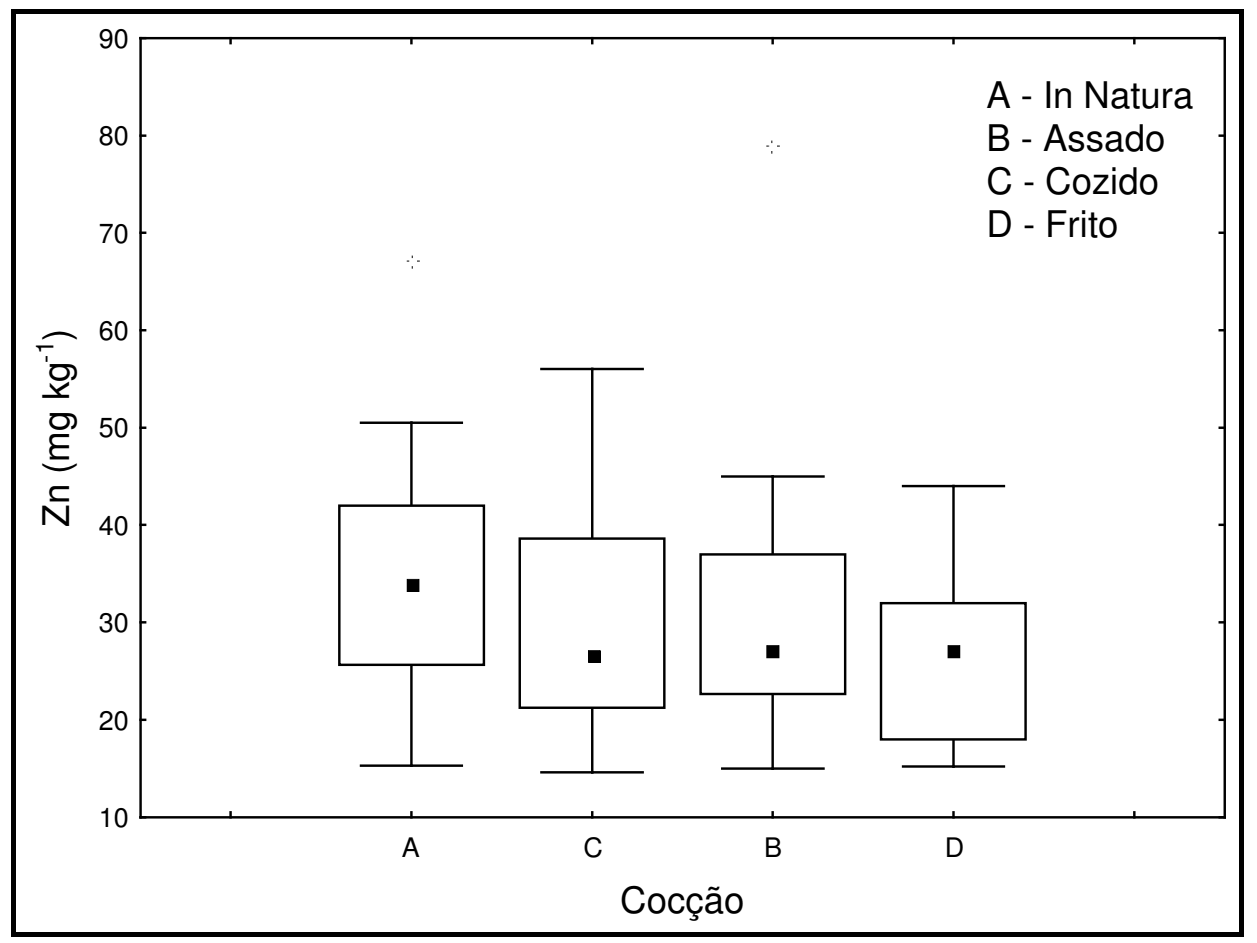

Figura 36. Boxplot da variação do teor de $\mathrm{Zn}$ nas amostras de peixe em função do processo de cocção.

É possível observar que apesar das altas variabilidades para os elementos $\mathrm{Ca}, \mathrm{Fe}, \mathrm{K}, \mathrm{Na}$, Se, $\mathrm{Zn}$ e $\mathrm{Hg}$ e tendo em vista que para cada tipo de preparo foram levadas em consideração diversas espécies, as medianas não diferem significativamente. Uma vez que nenhum desses elementos apresentou distribuição normal, conforme o teste de Shapiro-wilks $(\mathrm{p}<0,05)$, esta afirmação pôde ser confirmada pelo teste de Kruskal - Wallis ( $p>0,05)$.

Nas Figuras 37 a 43, avaliaram-se os teores de Ca, Fe, K, Na, Se, Zn e Hg nas amostras de peixe, em função da dieta alimentar de cada espécie. Observou-se neste estudo, que a variabilidade na perda dos elementos para cada processo de cocção, parece estar mais em função da espécie do que em função da forma de preparo, como citado anteriormente. Estes resultados indicam também um reflexo da amostragem, na qual foi priorizada um maior número de espécies com o objetivo de uma caracterização inicial dos pescados da região. Portanto, para afirmações mais conclusivas, em estudos futuros, é necessário analisar as flutuações dos teores dos elementos em um maior número de amostras de uma mesma espécie, visto que esta última variável mascara a primeira. 


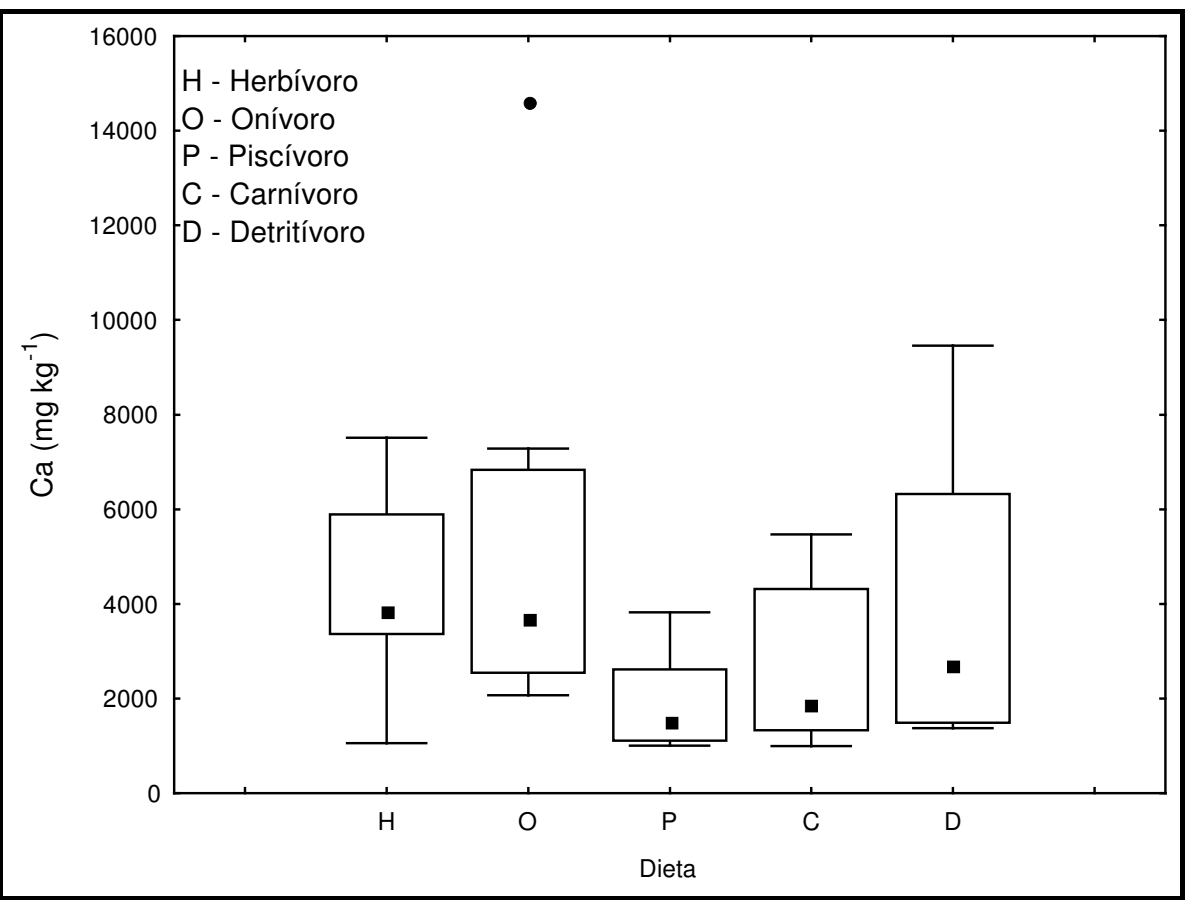

Figura 37. Boxplot da variação do teor de Ca nas amostras de peixe em função da dieta alimentar de cada espécie.

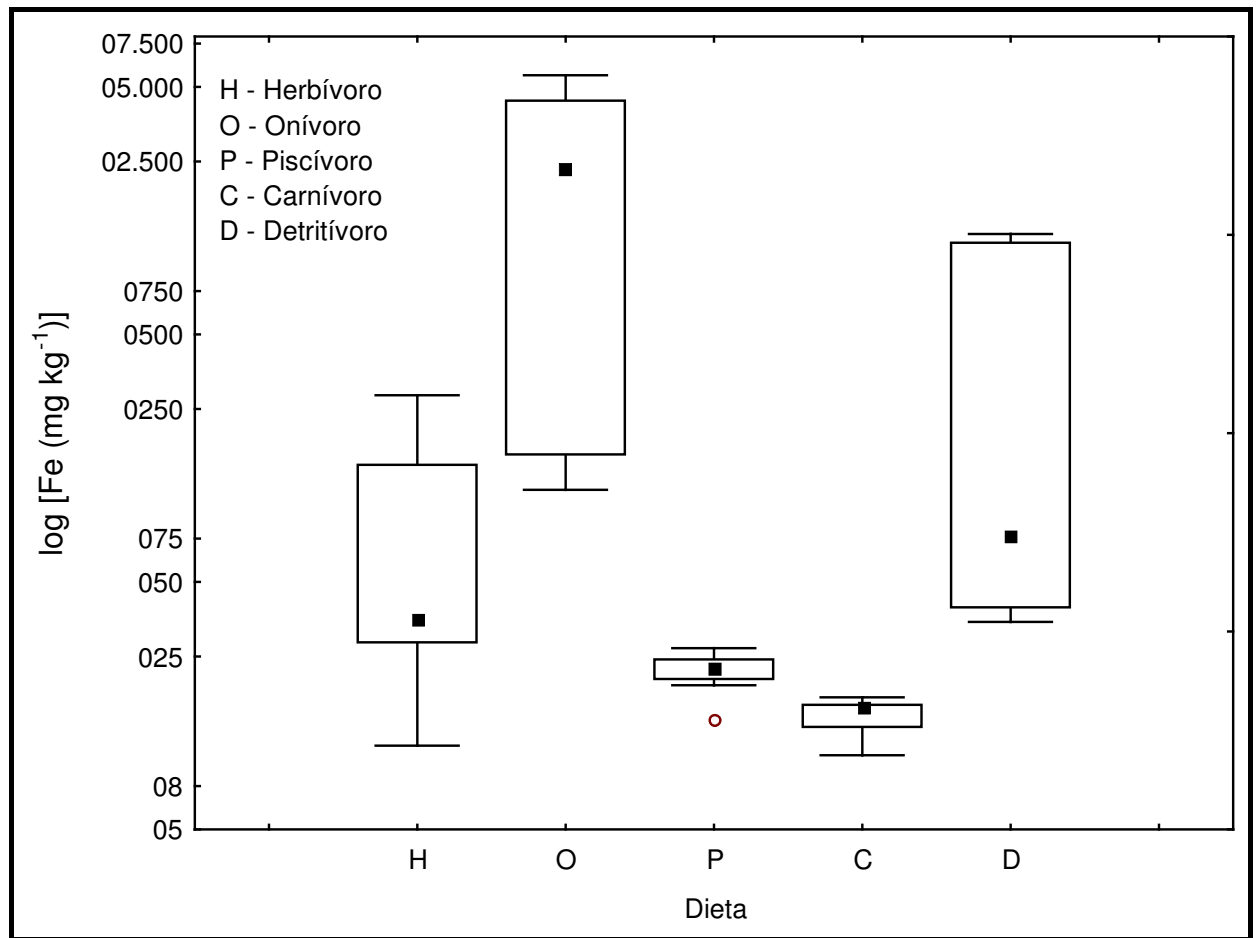

Figura 38. Boxplot da variação do teor de Fe nas amostras de peixe em função da dieta alimentar. 


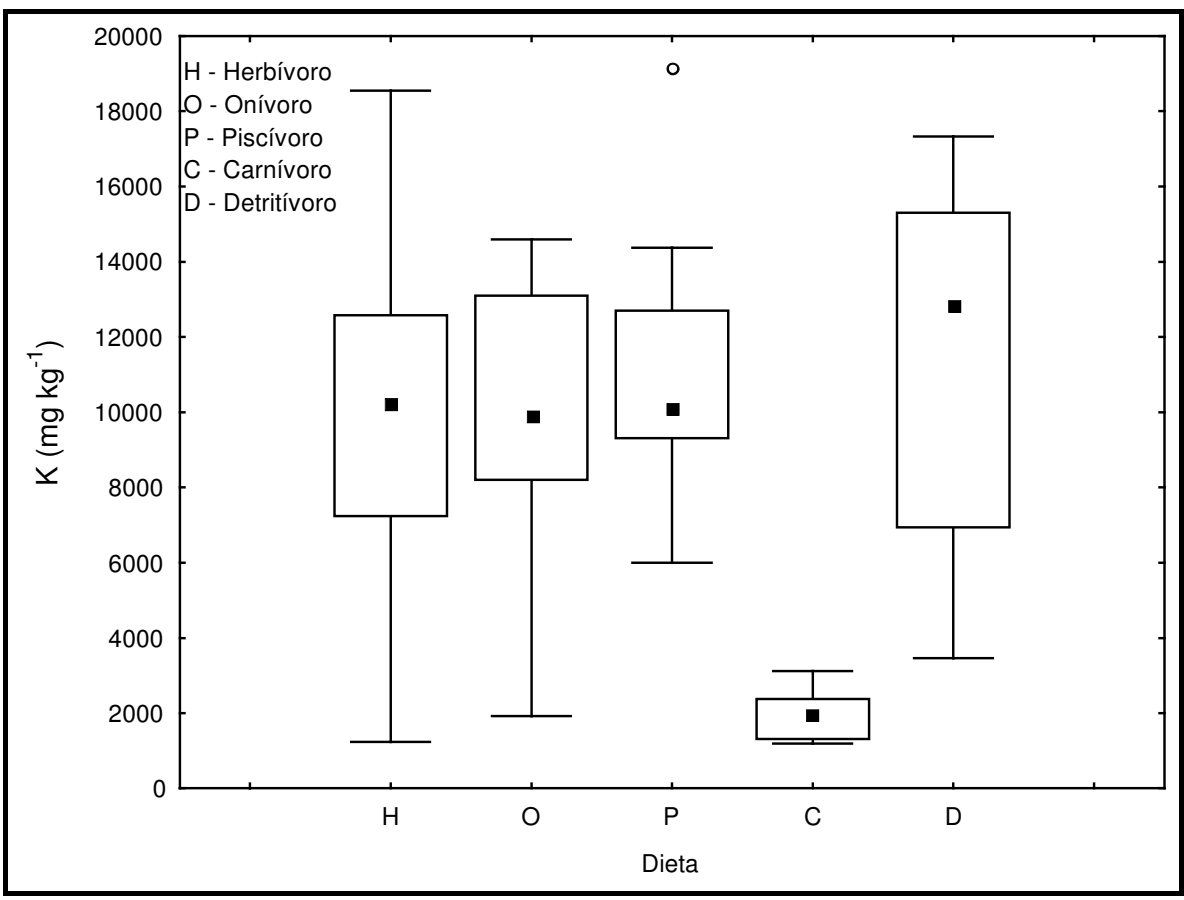

Figura 39. Boxplot da variação do teor de $\mathrm{K}$ nas amostras de peixe em função da dieta alimentar de cada espécie.

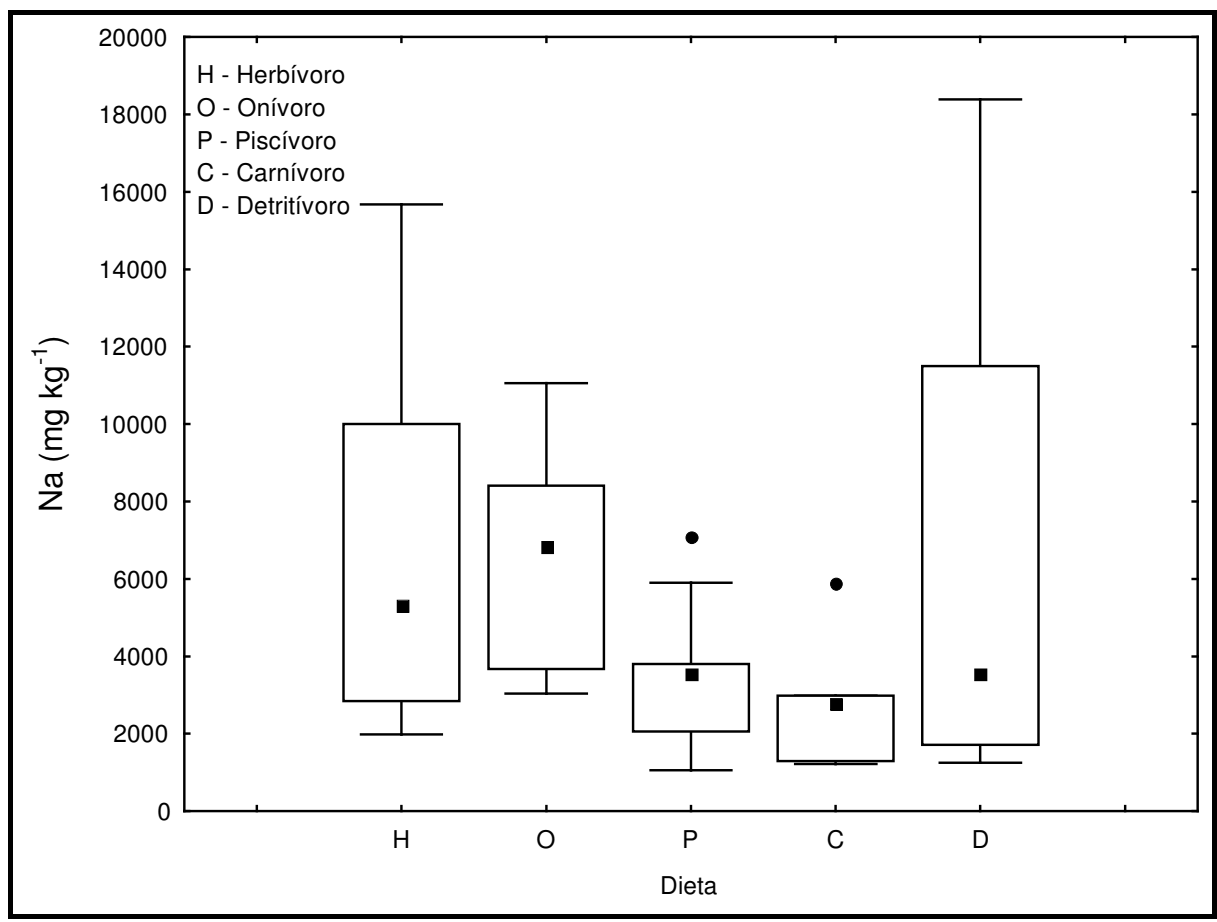

Figura 40. Boxplot da variação do teor de Na nas amostras de peixe em função da dieta alimentar de cada espécie. 


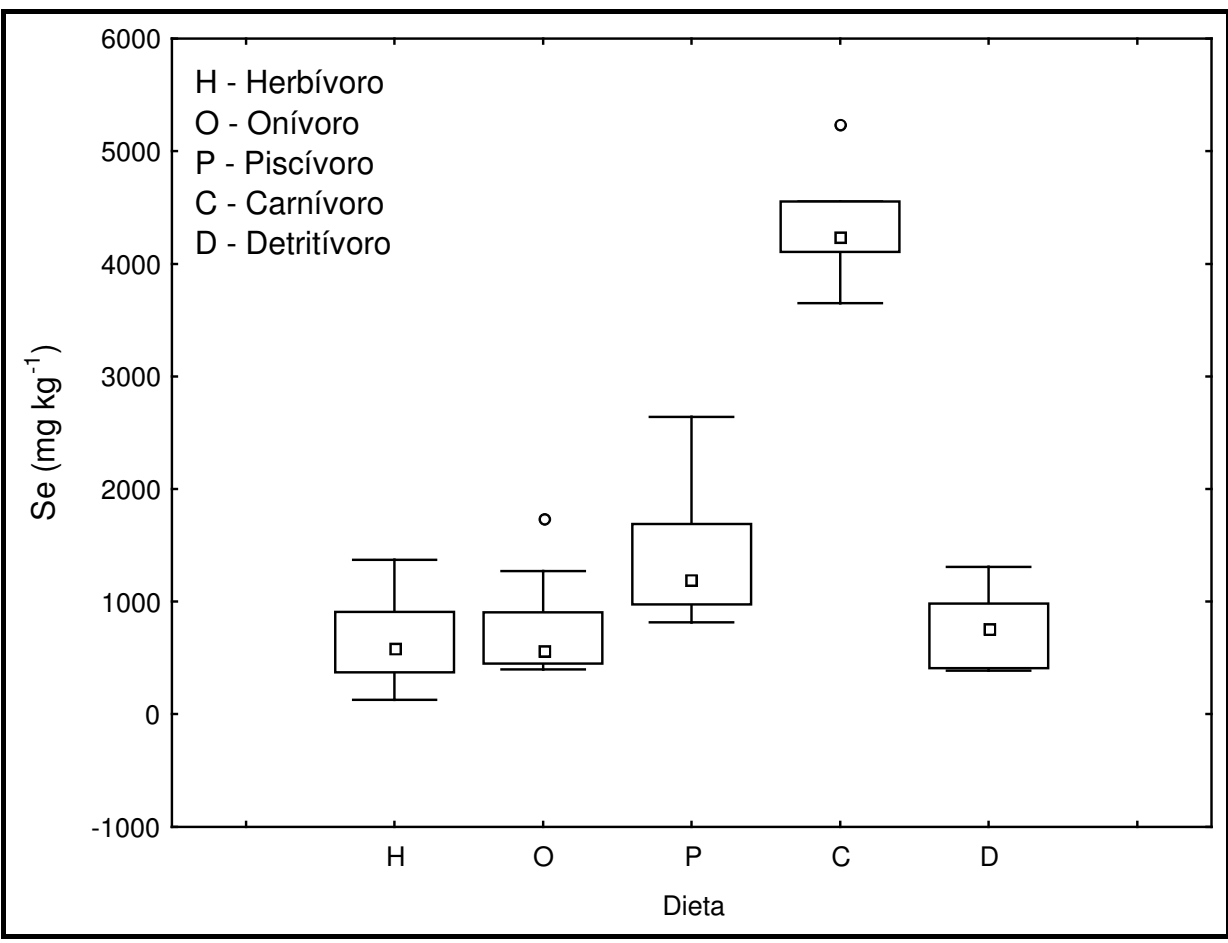

Figura 41. Boxplot da variação do teor de Se nas amostras de peixe em função da dieta alimentar de cada espécie.

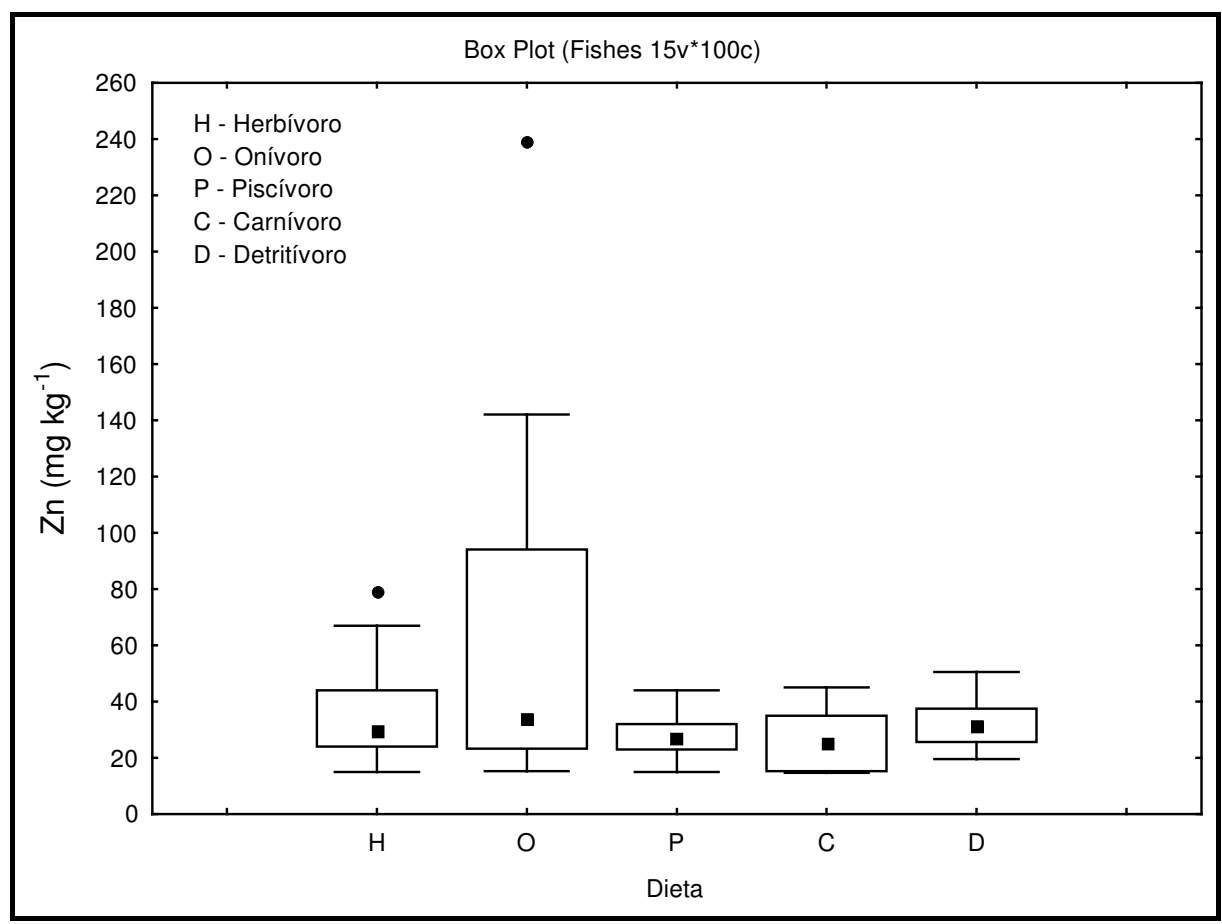

Figura 42. Boxplot da variação do teor de $\mathrm{Zn}$ nas amostras de peixe em função da dieta alimentar de cada espécie. 


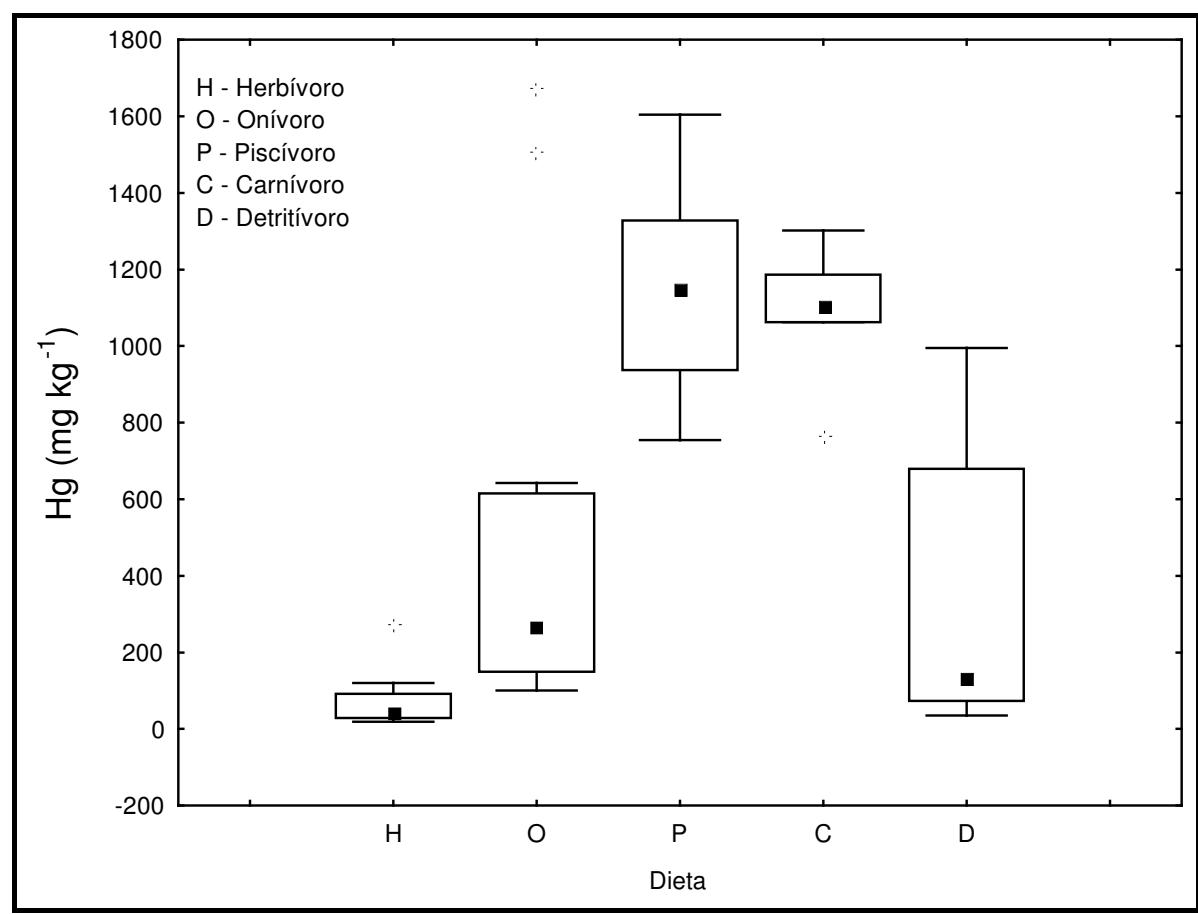

Figura 43. Boxplot da variação do teor de $\mathrm{Hg}$ nas amostras de peixe em função da dieta alimentar de cada espécie.

Uma vez que nenhum desses elementos apresentou distribuição normal, conforme o teste de Shapiro-wilks $(\mathrm{p}<0,05)$, aplicou-se o teste não paramétrico de Kruskal - Wallis. Foi possível comprovar que as altas variabilidades para os elementos $\mathrm{Fe}, \mathrm{Se}$ e $\mathrm{Hg}$ realmente refletem medianas que diferem significativamente $(\mathrm{p}<0,05)$. Já para os elementos $\mathrm{Ca}, \mathrm{K}, \mathrm{Na}$ e $\mathrm{Zn}$ o teste de Kruskal Wallis indicou que as medianas não diferem significativamente $(\mathrm{p}>0,05)$. Observando-se os boxplot para estes elementos (Figuras 37, 39, 40 e 42), é possível verificar que apesar da variabilidade nas medianas, a dispersão é grande, confirmando o teste aplicado.

\section{Técnicas estatísticas multivariadas}

Uma questão importante na análise composicional das mais diversas matrizes está relacionada à representação dos resultados, onde o número de variáveis observadas para cada amostra pode dificultar a representação dos dados. Tendo em vista esta dificuldade, recorre-se a técnicas estatísticas multivariadas no sentido de explicar a estrutura dos dados em termos de poucas variáveis. $\mathrm{Na}$ técnica de componentes principais, a composição de cada amostra original pode ser 
convertida em seus escores principais tornando-se mais facilmente interpretáveis (Baxter, 1994 ${ }^{\mathrm{a}}$.) e a análise discriminante, para a qual os principais objetivos da técnica são encontrar funções das variáveis originais (funções discriminantes) que expliquem as diferenças entre as populações e que permitam alocar novos objetos em uma das populações envolvidas na análise (Baxter, 1994; Beharav, 2003).

Os resultados obtidos no presente estudo foram também confirmados por meio da utilização de técnicas estatísticas multivariadas, análise de componente principal e análise discriminante, as quais buscaram identificar grupos de amostras de composição química similares, para os elementos determinados.

Por meio da análise de componente principal (ACP), observou-se que quatro primeiros componentes principais explicam $76,3 \%$ da variabilidade das amostras e no biplot apresentado na Figura 44, no qual o primeiro componente principal versus o segundo componente, pode-se observar que as amostras se agrupam de acordo com os hábitos alimentares. O grupo dos carnívoros (C) se apresentou como um grupo amplamente distinto das demais espécies, mesmo quando comparado aos piscívoros, que também se apresentou como um grupo isolado e que para alguns autores pode ser considerado como um subgrupo da espécie carnívora. O grupo dos herbívoros, detritívoros e onívoros, apresentaram-se como um grupo à parte e dispersos entre si. De acordo com essa mesma Figura é possível observar que os elementos que estão discriminando os grupos são o $\mathrm{Hg}$ e o $\mathrm{Se}\left(2^{\circ}\right.$ e $3^{\circ}$ quadrantes), os quais apresentam maiores teores nas espécies predadoras, conforme apresentado nos boxplots das Figuras 41 e 43. Essa relação não é inesperada, visto ser conhecido que o Se parece interagir com o $\mathrm{Hg}$ e as proteínas, formando complexos que protegem o organismo dos efeitos tóxicos desse metal sobre os rins, intestinos e sistema nervoso em animais e seres humanos.

Considerando a proposição apriorística que as amostras apresentam composição química diferenciada em relação ao hábito alimentar da espécie, realizou-se em seqüência a análise discriminante, a qual combina linearmente as variáveis originais com o objetivo de maximizar a diferença entre os grupos e miniminar a variância interna de cada grupo (Beharav \& Nevo, 2003). $\mathrm{Na}$ Figura 45 são apresentados os escores discriminantes no plano formado pelos eixos correspondentes as duas primeiras funções discriminantes. É possível confirmar as inferências já observadas na análise de componentes principais apresentadas anteriormente, ou seja, os carnívoros e piscívoros formando grupos distintos dos demais. O grupo dos onívoros amplamente disperso e com uma pequena sobreposição no grupo formado pelos herbívoros e detrítivoros, aqui 
considerados como um único grupo, visto apresentarem composição química similar nestas amostras.

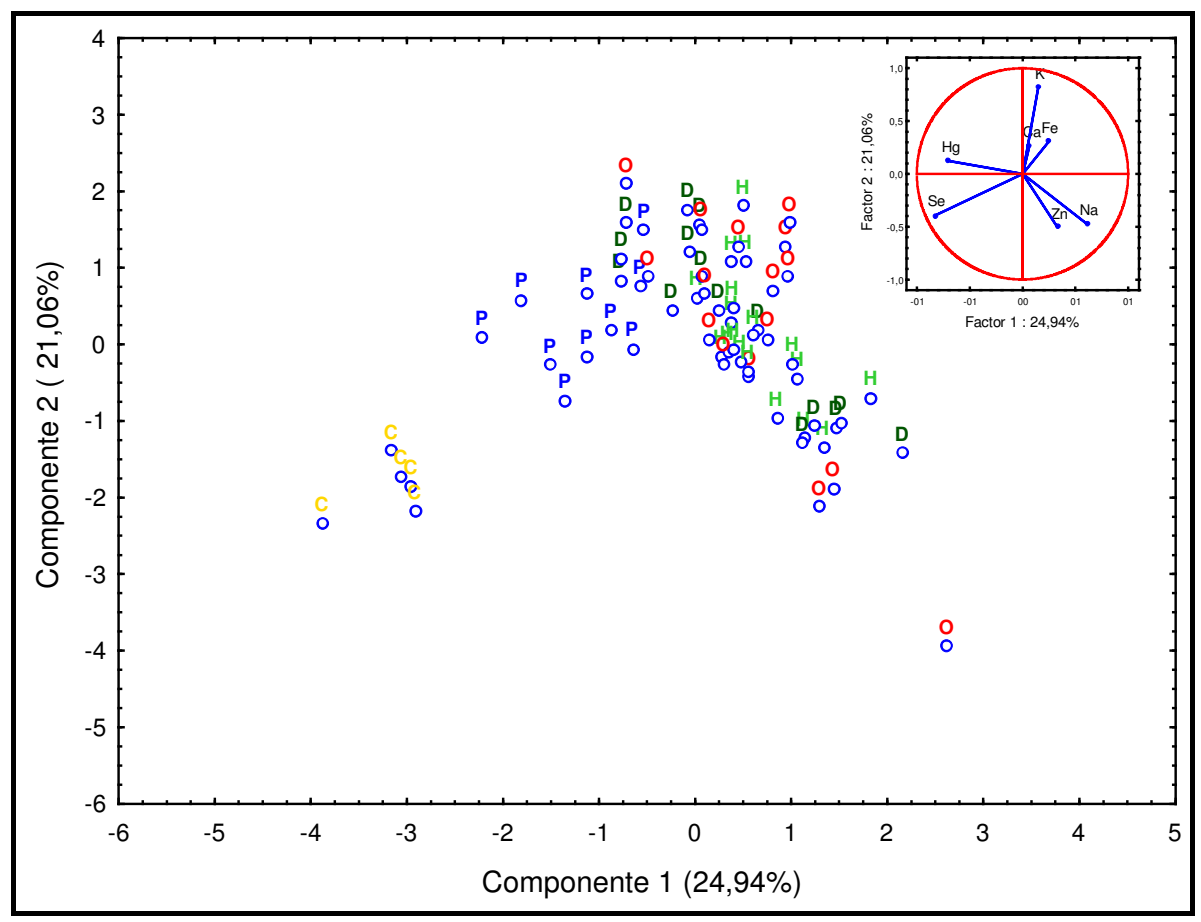

Figura 44. Biplot para as amostras de peixe em função da dieta alimentar de cada espécie.

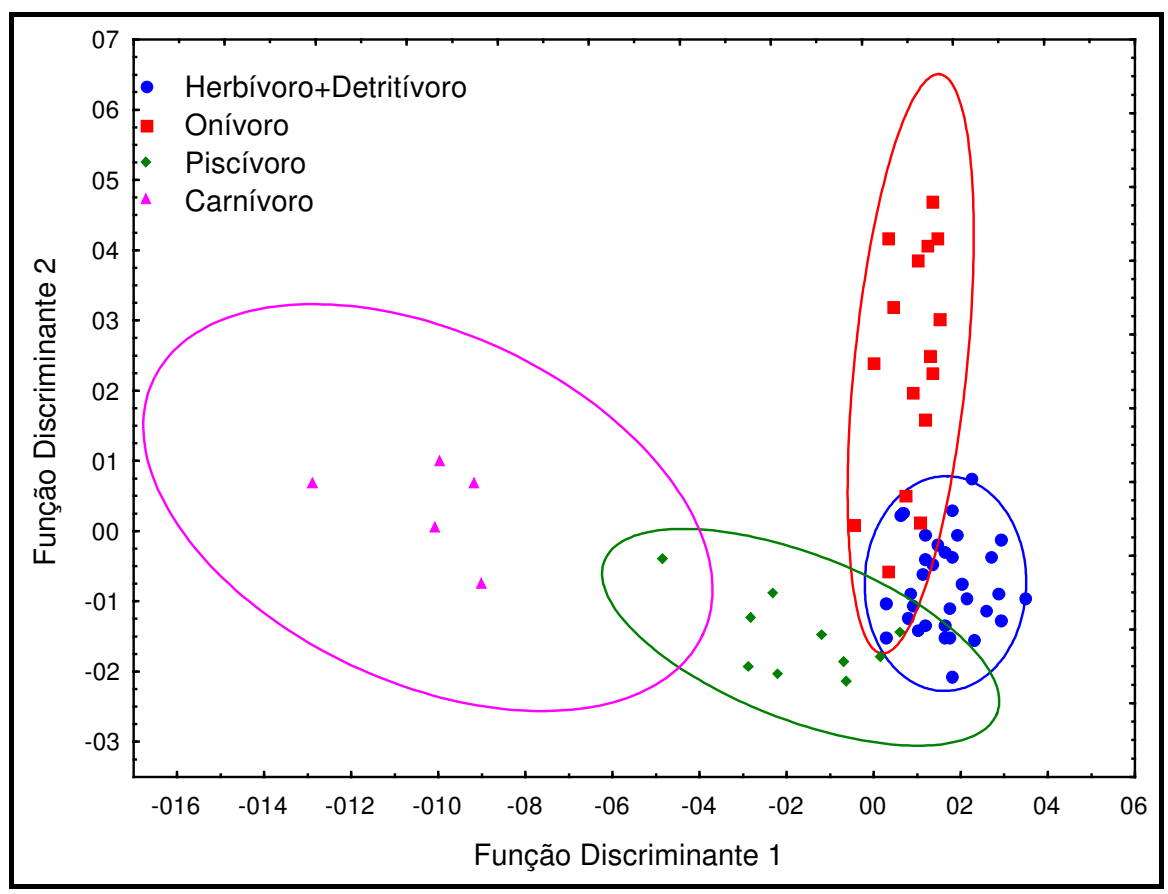

Figura 45. Representação da composição química elementar das amostras de peixe em função da dieta alimentar para cada espécie, no espaço das funções discriminantes (as elipses representam nível de confiança de 95\%). 


\section{Relação $\mathrm{Hg}$ e Se}

A importância da relação entre esses dois elementos ficou evidenciada na última Conferência Internacional sobre $\mathrm{Hg}$, realizada em Madison, EUA ( ${ }^{\text {th }}$ International Conference on Mercury as a Global Pollutant), no período de 6 a 11 de agosto de 2006. Dentre os inúmeros trabalhos apresentados nesta Conferência, 40 discutiram ou apresentaram resultados de determinações destes dois elementos em diversas matrizes. Destes 40, 14 (ou 35\%) afirmam ter observado a evidência de um papel protetor atribuído ao Se. Destacando-se neste sentido o trabalho entitulado: Blood Selenium and Mercury Relation in the Brazilian Amazon, da Universidade de Quebec, Canadá, o qual objetivou avaliar a quantidade disponível de Se e Hg no sangue (B-Se e B$\mathrm{Hg}$, respectivamente), caracterizar a variação do B-Se relacionada às variáveis dietéticas, sóciodemográficas e geográficas e avaliar a relação entre o B-Se e o B-Hg. Do total de 236 pessoas, das seis comunidades ribeirinhas do rio Tapajós participantes do estudo, nenhuma apresentou deficiência de B-Se. A concentração de B-Se variou entre as comunidades, apresentando valores significativamente mais altos nas pessoas que consumiam bebida alcoólica, mas não apresentou nenhuma relação com a idade, sexo ou consumo de tabaco. Os resultados obtidos também apresentaram uma relação positiva e significativa entre B-Se e B-Hg, independente do consumo total de peixe, indicando que para esta comunidade com alta exposição ao $\mathrm{Hg}$, o Se parece ter um papel importante (Lemire e col., 2006).

Nove trabalhos (ou 22,5\%) afirmam não ter observado nenhuma evidência de um papel protetor atribuído ao Se ou nenhuma correlação entre os dois elementos. Destacando-se neste sentido o trabalho entitulado: Selenium as a Potential Protective Factor Against Mercury Developmental Neurotoxicity, da Universidade de Saúde Pública de Harvard, o qual avaliou a interação existente entre o $\mathrm{Hg}$ e o Se, em população consumidora de peixe e carne de baleia (conhecida por seu alto teor de $\mathrm{Hg}$ ), residente nas Ilhas Faroe. Dois coorte foram efetuados a fim de realizar o estudo, o primeiro formado por nascidos no perído de 1986-1987 e o segundo coorte, formado por nascidos no período de 1994-1995. Os teores de $\mathrm{Hg}$ e $\mathrm{Se}$ foram determinados no sangue do cordão umbilical. Para o coorte 1, o resultado do desenvolvimento neural das crianças foi avaliado durante 7 anos, e para as crianças do coorte 2, estas avaliações foram realizadas em diversas ocasiões até a idade 7 anos. Em média, o Se presente no cordão umbilical, apresentou uma concentração 10 vezes maior em relação ao $\mathrm{Hg}$, indicando não haver deficiência nutricional deste elemento. O coeficiente de correlação entre o Hg e Se foi de $0,29(\mathrm{p}=, 0005)$, sugerindo que não há evidência que o Se tenha tido um papel protetor significativo com relação a neurotoxicidade do MeHg. Conclui-se então, que os esforços preventivos devem dirigir-se mais em direção a prevenir a exposição ao MeHg, do que garantir a ingestão de Se para este fim (Choi e col., 2006). 
Para os demais trabalhos, cinco (ou 12,5\%) apresentaram resultados nos quais altas concentrações de Se correspondiam a baixas concentrações de $\mathrm{Hg}$, seis (ou 15\%) sugeriram proteção relativa, ou seja, o Se retardaria o aparecimento dos efeitos adversos do $\mathrm{Hg}$ e seis (ou $15 \%$ ) somente apresentaram resultados da determinação destes dois elementos em diferentes matrizes, não discutindo a interação entre os dois. 


\section{CAPÍTULO 8}

\section{Conclusões e considerações finais sobre contaminação por mercúrio e fatores nutricionais}

\section{Contribuições analíticas}

A utilização da espectrometria de absorção atômica por geração de vapor frio (CV AAS) para a determinação de $\mathrm{Hg}$ em amostras biológicas mostrou-se efetiva para a determinação deste elemento. Os resultados obtidos para a determinação do $\mathrm{Hg}$ total nos materiais de referência biológicos mostraram desvios padrões relativos 1,4 a 5,4\% e erros relativos de 0 a 5,2 \%, verificando-se a precisão e a exatidão do método, respectivamente. Verificou-se por meio desses dados que, para os materiais analisados, os erros relativos e os desvios padrões relativos foram inferiores a 6\%, com exceção do material de referencia Typical Diet cujo valor de informação para $\mathrm{Hg}$ total é de $5 \mu \mathrm{g} \mathrm{kg}^{-1}$, valor muito baixo e próximo ao LQ do método $\left(1 \mu \mathrm{g} \mathrm{kg}^{-1}\right)$. Pode-se observar pelos gráficos de controle dos materiais de referência, que o método e o procedimento analítico não sofreram flutuações significativas que comprometessem o resultado final das análises e consequentemente a determinação do $\mathrm{Hg}$ nas diversas matrizes estudadas.

Também para os resultados obtidos na determinação de $\mathrm{MeHg}$ nos materiais de referência Human Hair 085 e 086 (IAEA), com diferentes níveis de concentração de MeHg, a metodologia analítica se mostrou adequada, apresentando erros relativos de 0,4 a 1,5 \%, e desvios padrão de 2,2 a 6,2 \%. Novamente pode-se observar pelos gráficos de controle dos materiais de referência, que o método e o procedimento analítico não sofreram flutuações significativas que comprometessem o resultado final das análises e, conseqüentemente, a determinação do $\mathrm{MeHg}$ na matriz estudada.

O cálculo da incerteza expandida avaliada no presente estudo, para as metodologias utilizadas na determinação do $\mathrm{Hg}$ total e $\mathrm{MeHg}$ pela técnica de $\mathrm{CV}$ AAS, correspondeu a aproximadamente $14 \%$ da concentração final de $\mathrm{Hg}$ nos materiais certificados, sendo este valor da mesma ordem de grandeza de outros estudos encontrados na literatura. 
A participação em um exercício de intercomparação patrocinado pela IAEA, com o objetivo de avaliar as metodologias analíticas utilizadas na determinação de $\mathrm{Hg}$ total e $\mathrm{MeHg}$ em um material candidato a material de referência (Tuna Fish Flesh Homogenate (IAEA-436)) apresentou resultados bastante satisfatórios. Foram observados valores de desvio padrão relativo 1,1 e 1,4\% e erros relativos de 10,5 e 0,5\%, respectivamente para as determinações de $\mathrm{Hg}$ total e $\mathrm{MeHg}$, comprovando a precisão e a exatidão das metodologias analíticas utilizadas.

A utilização da (AAN) permitiu determinar os valores de concentração para elementos nutricionalmente importantes como $\mathrm{Ca}, \mathrm{Fe}, \mathrm{K}, \mathrm{Na}, \mathrm{Se}$ e $\mathrm{Zn}$. A precisão e a exatidão do método foram verificados por meio da análise de materiais de referência e os resultados apresentaram desvios padrão relativos de 0,5 a $9,1 \%$ e erros relativos de 0,0 a 7,8\%. O método se mostrou bastante adequado para a obtenção de resultados confiáveis para esses elementos.

A técnica de amostragem da porção em duplicata utilizada para coleta das dietas das crianças do PNJ, também mostrou-se adequada e juntamente com os métodos analíticos utilizados é uma boa alternativa para se fazer uma avaliação dietética real desses elementos e muito pode contribuir para estudos de possíveis correlações entre deficiências dietéticas de elementos inorgânicos e enfermidades apresentadas por determinados grupos de indivíduos. Entretanto, convém salientar que mesmo as dietas estudadas apresentando, de um modo geral, um baixo ajuste nos requerimentos de energia e de minerais, estes valores foram baseados no recordatório de apenas um dia.

\section{Considerações finais}

Ao ser criada uma relação, eminentemente concreta, entre a saúde e o meio ambiente, observa-se que a influência deste último pode ser positiva ou negativa, na medida em que promove condições que propiciam o bem-estar e a plena realização das capacidades humanas para todas as populações ou, por outro lado, contribuem para o aparecimento e manutenção de doenças, agravos e lesões traumáticas, assim como para o aniquilamento e morte da população como um todo, ou para grupos populacionais específicos. E a contaminação ambiental por poluentes químicos, por sua vez, é um importante fator na geração de agravos à saúde. 
Os elevados teores de $\mathrm{Hg}$ encontrados em peixes que habitam áreas próximas e distantes de sítios de mineração de ouro na Amazônia não são apenas o reflexo da grande quantidade de $\mathrm{Hg}$ lançada no ambiente, mas também o resultado das condições ambientais dos ecossistemas aquáticos dessa região. Estas condições favorecem altas taxas de metilação e, portanto, uma apreciável acumulação nas espécies de peixes de níveis tróficos superiores, como é o caso do rio Jaú e do rio Negro, abordados no presente estudo. Ambos são ecossistemas de águas escuras e terras inundáveis que possuem características biogeoquímicas que favorecem a metilação do $\mathrm{Hg}$ na biota aquática.

Com base nos experimentos realizados neste trabalho, observou-se que os teores obtidos para $\mathrm{Hg}$ total nas dietas de pré-escolares residentes no PNJ, estiveram bem acima dos valores encontrados em diferentes regiões do Brasil, bem como, de outras localidades da região Amazônica, apresentando resultados acima da ingestão considerada tolerável, segundo os valores de ingestão semanal tolerável provisória (PTWI) ou os valores de ingestão diária aceitável (ADI) preconizados pela Organização Mundial de Saúde para a ingestão de Hg, situação esta agravada pela ingestão deficiente de micronutrientes e déficit protéico-calórico encontrado nas dietas analisadas no presente trabalho. Com relação a ingestão de $\mathrm{Ca}$, somente $8,3 \%$ das dietas avaliadas atingiram o valor preconizado; para o $\mathrm{K}$, nenhuma das dietas atingiu o valor recomendado para a faixa etária estudada e para o $\mathrm{Zn}$, somente $17 \%$ das dietas atingiram o valor preconizado; para o Fe, segundo os valores EAR para crianças (4 a 8 anos), constatou-se que para $75 \%$ das dietas analisadas atingiram o valor preconizado; para o $\mathrm{Na}, 42 \%$ das dietas atingiram o valor preconizado e para o Se constatou-se que $42 \%$ das dietas atingiram valores adequados de acordo com o valor EAR (23 $\mu \mathrm{g} / \mathrm{dia}$ ) e duas comunidades, Jacaré e Serigalzinho, ambas pertencentes ao PNJ, ultrapassaram o valor de AI recomendado para este estágio de vida para este elemento.

Observando-se que as práticas de alimentação serem importantes determinantes das condições de saúde não somente na infância, como na vida adulta e estarem fortemente condicionadas ao poder aquisitivo das famílias, do qual dependem a disponibilidade, a quantidade e a qualidade dos alimentos consumidos, pode-se inferir que os resultados encontrados para o PNJ mostram o alto nível de risco e a vulnerabilidade da população às deficiências nutricionais e à contaminação por $\mathrm{Hg}$, cujos teores em amostras de cabelo está diretamente relacionado com a ingestão de peixe.

Os níveis de $\mathrm{Hg}$ total e de $\mathrm{MeHg}$ encontrados nas amostras de cabelos das crianças residentes no PNJ foram, em geral, muito elevados mesmo quando comparados com outras regiões da Amazônia sob influencia antrópica de $\mathrm{Hg}$, excedendo o valor de $\mathrm{Hg}$ no cabelo de $6 \mathrm{mg} \mathrm{\textrm {kg } ^ { - 1 }}$ que 
corresponde à ingestão semanal de $\mathrm{MeHg}$ estabelecida, provisoriamente, como tolerável pela WHO e $2 \mathrm{mg} \mathrm{kg}^{-1}$ (Hg total) correspondente ao valor comumente encontrado em população não exposta.

Frente a esse quadro grave de exposição ao $\mathrm{Hg}$, em que se encontram os pré-escolares do PNJ, uma avaliação clínica dos prováveis efeitos deletérios provocados pela ingestão de altos teores de $\mathrm{Hg}$ seria muito pertinente e necessária. Infelizmente, dentro deste estudo, não foi possível conseguir recursos financeiros para a realização de uma nova campanha de amostragem com a participação de médicos especialistas nessa área para fazer essa avaliação clínica. Visto que estudos atuais vêm revelando sempre os inúmeros problemas ocasionados pela exposição crônica ao $\mathrm{Hg}$, como por exemplo o trabalho intitulado: Mercury Toxicity: visual disfunction following mercury exposure by breathing mercury vapor and by eating mercury contaminated food, também apresentado na $8^{\text {th }}$ International Conference on Mercury as a Global Pollutant e desenvolvido por médicos da Universidade Federal do Pará, Belém, estado do Pará, o qual aborda métodos específicos e refinados, para a detecção de problemas de perda visão relacionados com a contaminação por Hg, já que este problema é um dos primeiros sintomas apresentados quando da intoxicação pelo elemento.

Visto que a freqüência com que as populações comem pescado é determinada pelo número de opções protéicas de uma determinada comunidade, juntamente com o aspecto econômico e social, pode-se entender porque a população de Manaus apresentou teores muito menores de Hg nas amostras de cabelo, ao contrário da população residente no PNJ, mesmo sendo ecossistemas interligados. A ingestão de peixe é menor, conseqüentemente a ingestão de $\mathrm{Hg}$ também, quando a população possui maior capacidade de escolha de produtos alimentícios fornecedores de proteínas. Informação essa confirmada pela Pesquisa de Orçamentos Familiares realizada pelo IBGE (POF 2002 - 2003). Entretanto, nessa mesma pesquisa, fica evidenciada a importância da carne de peixe como fonte protéica para a população da Região Norte, que se destaca também pelo maior percentual de despesa familiar com pescados frescos, ficando muito acima das demais regiões brasileiras.

Além de boa fonte protéica, a ingestão de peixe apresenta alto potencial nutritivo, caracterizando-se como importante componente no estabelecimento de dietas adequadas, particularmente para populações ribeirinhas. Contudo, a despeito da grande quantidade de informação existente em relação ao teor de $\mathrm{Hg}$ e de outros elementos minerais em várias espécies desta região, estas se referem na maioria das vezes à composição química do peixe in natura e não à forma em que os peixes são usualmente consumidos pela população. Objetivando avaliar também a 
influência do processo de cocção na perda de nutrientes e eliminação do $\mathrm{Hg}$, em uma tentativa de contribuir para futuros estudos nutricionais, avaliou-se o teor de $\mathrm{Hg}$ e dos micronutrientes $\mathrm{Ca}, \mathrm{Fe}$, $\mathrm{K}$, Na, Se e Zn em espécies de peixes comumente consumidas pela população da cidade de Manaus e comunidades próximas, preparadas sob diferentes formas de cocção. Constatou-se que a variabilidade na perda dos elementos minerais e do $\mathrm{Hg}$, para cada processo de cocção, parece estar mais em função da espécie do que em função da forma de preparo. Vale destacar que as espécies predadoras (representadas no presente estudo pelas espécies Tucunaré e Pescada) apresentaram os maiores teores de $\mathrm{Hg}$ e Se, conforme o esperado. Esta interação foi confirmada por meio da análise de componente principal, onde observou-se que os elementos que discriminam os grupos são o $\mathrm{Hg}$ e o Se ( $2^{\circ}$ e $3^{\circ}$ quadrantes), os quais apresentam maiores teores nas espécies predadoras.

Apesar da controvérsia existente entre as inúmeras pesquisas referentes ao papel protetor que o Se exerceria em relação à contaminação por $\mathrm{Hg}$ e $\mathrm{MeHg}$, é evidente a relação existente entre estes dois elementos, como pôde ser constatado a partir dos inúmeros trabalhos apresentados na $8^{\text {th }}$ International Conference on Mercury as a Global Pollutant. Entretanto, ficou evidenciado que estudos mais aprofundados são necessários para que se consiga elucidar totalmente inúmeras questões, tais como: os mecanismos relacionados ao efeito antagônico, altas concentrações de Se, frente a menores concentrações de $\mathrm{Hg}$, a aparente evidência do papel do Se no retardo do aparecimento dos efeitos adversos devido a bioacumulação do $\mathrm{MeHg}$ e a formação de complexos estáveis no fígado, a partir de selenoproteínas e o real papel deste órgão na desentoxicação do organismo com relação ao Hg.

Apesar de alguns pesquisadores acreditarem que, ao menos nos níveis atuais, a presença de Hg no pescado amazônico não afeta a saúde da população e a que a explicação dos altos teores de Hg na região é dada pela própria abundância natural do elemento nas rochas da região do rio Negro, outros pesquisadores, contudo, pedem cautela diante de tais conclusões. Apesar das pesquisas atuais concordarem que possa existir um BG (nível básico) de Hg na Amazônia, assim como existe no Canadá, é de conhecimento geral que nesse país, esse fator não impediu o surgimento da "doença dos peixes" encontrada nos índios que, em determinados períodos, eram forçados a consumir mais peixes, segundo o prof. ${ }^{\circ}$ Ribeiro, da UFPR, em entrevista dada a revista eletrônica Ambiente Brasil. Portanto, a exposição contínua ao $\mathrm{Hg}$ pela via alimentar, mesmo considerando os baixos teores do metal encontrados em algumas espécies de peixes, permitem supor que no decorrer do tempo esta situação possa se agravar, principalmente em comunidades cuja dieta não é diversificada, apresenta deficiências nutricionais e se constitua principalmente de pescado. 
Por fim, o conhecimento científico tem avançado no sentido de elaborar e estabelecer relações entre um grande número de indicadores ambientais e de saúde, notadamente aqueles referentes a morbidades particulares e processos fisiopatológicos, mas também indicadores biológicos de exposição. Portanto, para ajuizar e explicitar cientificamente a relação ambientesaúde, torna-se necessário que esteja disponível um estoque de informações passadas e atuais sobre os dois termos da relação. Neste sentido, o presente estudo procurou trazer à luz, como dois municípios, embora sendo ecossistemas interligados, mas com sistemas de produção contrastantes, em que modelos sofisticados e modernos se opõem a formas "primitivas" e tradicionais de exploração e uso dos recursos naturais, podem apresentar diferentes graus de impactação. É importante ressaltar que a determinação do $\mathrm{Hg}$ oriundo de fontes naturais ou antrópicas é relevante para avaliar os riscos toxicológicos devido a sua acumulação nos recursos biológicos, como por exemplo em peixes predadores, que estão no topo da cadeia alimentar aquática e podem acumular grande quantidade de metais, ressaltando-se que esta população, particularmente as comunidades ribeirinhas do PNJ, não podem se abster desta importante fonte de proteínas e micronutrientes. $\mathrm{Na}$ realidade brasileira, não há disponibilidade dessas informações para todo o espaço delimitado pelo país, seja para o meio ambiente, seja para a saúde. Além disso, ainda há necessidade de mais estudos que tenham por objetivo estudar esta relação em suas múltiplas possibilidades. 
ANEXOS 


\section{ANEXOS}

ANEXO I - Resultados obtidos para mercúrio total, na análise do material candidato a material de referencia IAEA -436.

\section{MERCÚRIO TOTAL - IAEA 436}

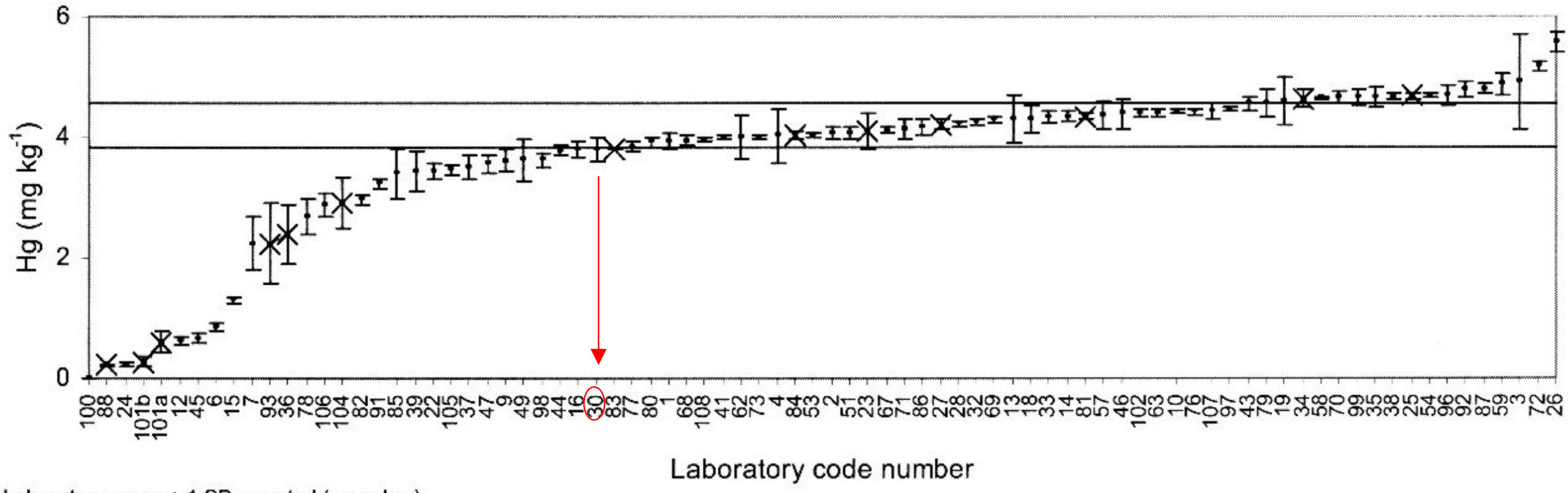

Laboratory mean \pm 1 SD reported (error bar)

Horizontal lines $=$ Mean value $\pm 1 \mathrm{SD}($ Cof ino 1 st mode $) ; O=$ out of scale; $X=$ no $Q A$ reported

Figura 17 . Gráfico de apresentação dos resultados obtidos para Hg total na intercomparação pelos laboratórios participantes. 
ANEXO II - Resultados obtidos para metilmercúrio, na análise do material candidato a material de referencia IAEA -436.

METILMERCÚRIO - IAEA 436

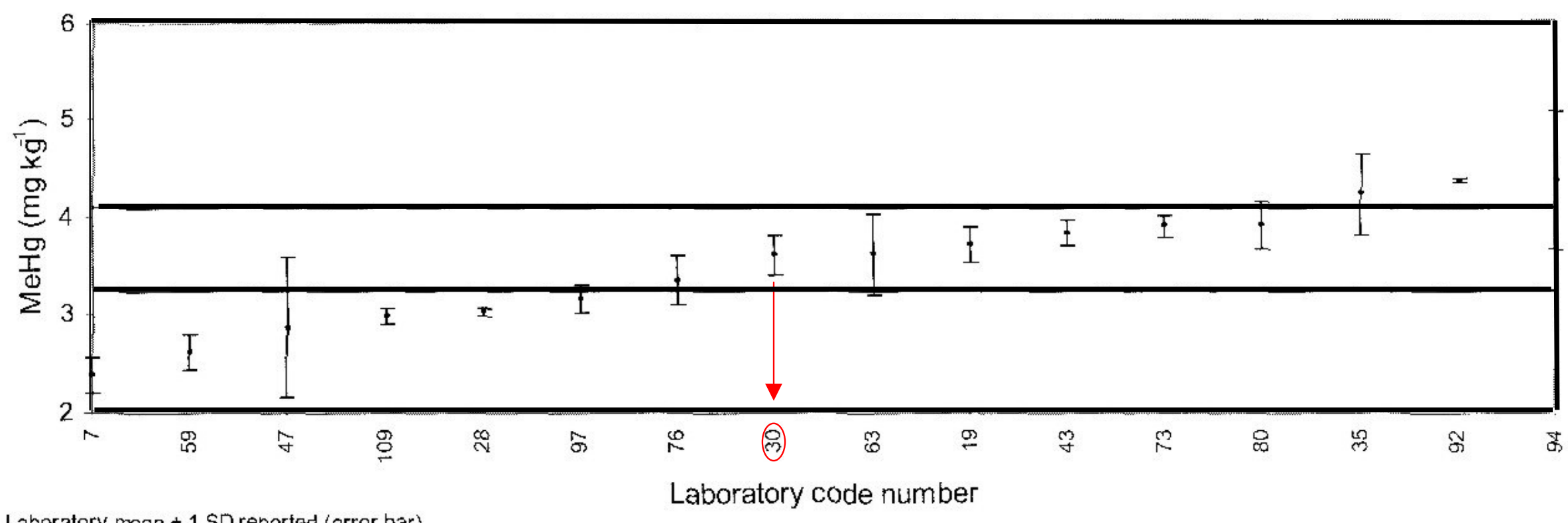

Laboratory mean \pm 1 SD reported (error bar)

Horizontal lines = Mean value $\pm 1 S D($ Cofino 1 st mode); $O=$ out of $\mathrm{scale} ; X=$ no $Q \mathrm{~A}$ reported

Figura 18 . Gráfico de apresentação dos resultados obtidos para MeHg na intercomparação pelos laboratórios participantes. 


\section{ANEXO III - Mercúrio total em dietas}

Tabela 17 - Teor de Hg total em dietas, com os desvios padrões e as incertezas expandidas para as comunidades do PNJ e demais comunidades da região Amazônica

\begin{tabular}{l|c|c}
\hline \multicolumn{1}{c|}{ Comunidades } & $\begin{array}{c}\text { Hg Total }\left(\mu \mathbf{~ k g}^{-1}\right) \\
(\text { média } \pm \text { d.p. })\end{array}$ & $\begin{array}{c}\text { Incerteza Expandida } \\
\mathbf{U}\left(\mu \mathbf{~ k g}^{-1}\right)\end{array}$ \\
\hline Cachoeira (3) & $380 \pm 22$ & \pm 53 \\
Jacaré (3) & $337 \pm 23$ & \pm 47 \\
Santo Elias (3) & $803 \pm 78$ & \pm 112 \\
Seringalzinho (3) & $505 \pm 94$ & \pm 71 \\
Vista Alegre (3) & $645 \pm 39$ & \pm 90 \\
Alvarães* (2) & $61 \pm 3$ & \pm 8 \\
Itapiranga * (2) & $89 \pm 9$ & \pm 12 \\
Nhamundá* (2) & $36,7 \pm 0,1$ & $\pm 5,1$ \\
Nogueira* (2) & $78 \pm 5$ & \pm 11 \\
Novo Airão* (2) & $71 \pm 2$ & \pm 10 \\
SESI * (2) & $6,2 \pm 0,6$ & $\pm 0,9$ \\
Urucurituba* (2) & $88 \pm 9$ & \pm 12 \\
\hline
\end{tabular}

*Comunidades região Amazônica.

$*(n)$ - de determinações. 


\section{ANEXO IV - Mercúrio total em cabelos}

Tabela 19 - Teor de Hg total em cabelos, com os desvios padrões (s) e as incertezas expandidas para as comunidades do PNJ

\begin{tabular}{|c|c|c|}
\hline $\begin{array}{c}\text { Comunidade Cachoeira - } \\
\text { Código da amostra }\end{array}$ & $\begin{array}{l}\mathrm{Hg} \text { Total }\left(\mathrm{mg} \mathrm{kg}^{-1}\right) \\
\text { (média } \pm \text { d.p.) }\end{array}$ & $\begin{array}{c}\text { Incerteza Expandida } \\
\mathrm{U}\left(\mathrm{mg} \mathrm{kg}^{-1}\right) \\
\end{array}$ \\
\hline 27 & $20,8 \pm 0,2$ & $\pm 2,9$ \\
\hline 28 & $18,18 \pm 0,04$ & $\pm 2,5$ \\
\hline 29 & $1,39 \pm 0,02$ & $\pm 0,2$ \\
\hline 48 & $22,7 \pm 0,2$ & $\pm 3,2$ \\
\hline $\begin{array}{c}\text { Comunidade Santo Elias - } \\
\text { Código da amostra }\end{array}$ & $\begin{array}{l}\left.\text { Hg Total (mg kg }{ }^{-1}\right) \\
\text { (média } \pm \text { s.d.) }\end{array}$ & $\begin{array}{c}\text { Incerteza Expandida } \\
\mathbf{U}\left(\mathrm{mg} \mathrm{kg}^{-1}\right)\end{array}$ \\
\hline 127 & $34,2 \pm 0,2$ & $\pm 4,8$ \\
\hline 130 & $25,90 \pm 0,03$ & $\pm 3,6$ \\
\hline 134 & $38,4 \pm 0,9$ & $\pm 5,4$ \\
\hline 142 & $42,1 \pm 0,2$ & $\pm 5,9$ \\
\hline 151 & $42,2 \pm 0,1$ & $\pm 5,9$ \\
\hline 167 & $40,4 \pm 0,3$ & $\pm 5,6$ \\
\hline $\begin{array}{c}\text { Comunidade Seringalzinho } \\
\text { Código da amostra }\end{array}$ & $\begin{array}{l}\mathrm{Hg}_{\text {Total }}\left(\mathrm{mg} \mathrm{kg}^{-1}\right) \\
\text { (média } \pm \text { s.d.) }\end{array}$ & $\begin{array}{c}\text { Incerteza Expandida } \\
\mathrm{U}\left(\mathrm{mg} \mathrm{kg}^{-1}\right)\end{array}$ \\
\hline 60 & $8,58 \pm 0,05$ & $\pm 1,2$ \\
\hline 82 & $0,59 \pm 0,01$ & $\pm 0,1$ \\
\hline 89 & $4,67 \pm 0,01$ & $\pm 0,6$ \\
\hline 98 & $36,1 \pm 0,3$ & $\pm 5,0$ \\
\hline 100 & $14,12 \pm 0,05$ & $\pm 2,0$ \\
\hline $\begin{array}{c}\text { Comunidade Vista Alegre - } \\
\text { Código da amostra }\end{array}$ & $\begin{array}{l}\mathrm{Hg}^{\mathrm{H}} \text { Total }\left(\mathrm{mg} \mathrm{kg}^{-1}\right) \\
\text { (média } \pm \text { s.d.) }\end{array}$ & $\begin{array}{c}\text { Incerteza Expandida } \\
\mathrm{U}\left(\mathrm{mg} \mathrm{kg}^{-1}\right) \\
\end{array}$ \\
\hline 68 & $23,3 \pm 0,1$ & $\pm 3,3$ \\
\hline 73 & $17,9 \pm 0,2$ & $\pm 2,5$ \\
\hline 106 & $18,9 \pm 0,2$ & $\pm 2,6$ \\
\hline 114 & $13,4 \pm 0,1$ & $\pm 1,9$ \\
\hline
\end{tabular}




\section{ANEXO V - Mercúrio total em cabelos}

Tabela 20 - Teor de Hg total em cabelos, com os desvios padrões (s) e as incertezas expandidas para as demais comunidades da região Amazônica

\begin{tabular}{|c|c|c|}
\hline $\begin{array}{c}\text { Comunidade Ajuricaba - } \\
\text { Código da amostra }\end{array}$ & $\begin{array}{l}\text { Hg Total }\left(\mathrm{mg} \mathrm{kg}^{-1}\right) \\
\text { (média } \pm \text { d.p.) }\end{array}$ & $\begin{array}{c}\text { Incerteza Expandida } \\
\mathbf{U}\left(\mathrm{mg} \mathrm{kg}^{-1}\right)\end{array}$ \\
\hline 08 & $17,9 \pm 0,3$ & $\pm 2,5$ \\
\hline 09 & $22,5 \pm 0,9$ & $\pm 3,1$ \\
\hline 10 & $15,8 \pm 0,9$ & $\pm 2,2$ \\
\hline 11 & $12,9 \pm 0,7$ & $\pm 1,8$ \\
\hline 12 & $16,0 \pm 0,5$ & $\pm 2,2$ \\
\hline $\begin{array}{c}\text { Comunidade Alvarães } \\
\text { Código da amostra }\end{array}$ & $\begin{array}{l}\text { Hg Total }\left(\mathrm{mg} \mathrm{kg}^{-1}\right) \\
\text { (média } \pm \text { d.p.) }\end{array}$ & $\begin{array}{c}\text { Incerteza Expandida } \\
\mathrm{U}\left(\mathrm{mg} \mathrm{kg}^{-1}\right)\end{array}$ \\
\hline 03 & $5,10 \pm 0,03$ & $\pm 0,7$ \\
\hline 05 & $8,1 \pm 0,1$ & $\pm 1,1$ \\
\hline 06 & $15,5 \pm 0,9$ & $\pm 2,2$ \\
\hline 07 & $12,1 \pm 0,5$ & $\pm 1,7$ \\
\hline $\begin{array}{c}\text { Comunidade Borba - } \\
\text { Código da amostra }\end{array}$ & $\begin{array}{l}\text { Hg Total (mg kg-1) } \\
\text { (média } \pm \text { d.p.) }\end{array}$ & $\begin{array}{c}\text { Incerteza Expandida } \\
\mathrm{U}\left(\mathrm{mg} \mathrm{kg}^{-1}\right)\end{array}$ \\
\hline 54 & $8,6 \pm 0,1$ & $\pm 1,2$ \\
\hline 63 & $3,6 \pm 0,1$ & $\pm 0,5$ \\
\hline 69 & $1,8 \pm 0,1$ & $\pm 0,2$ \\
\hline 90 & $14,1 \pm 0,3$ & $\pm 2,0$ \\
\hline 98 & $4,8 \pm 0,1$ & $\pm 0,7$ \\
\hline $\begin{array}{c}\text { Comunidade Itapiranga - } \\
\text { Código da amostra }\end{array}$ & $\begin{array}{l}\mathrm{Hg} \text { Total (mg kg } \\
\text { (média } \pm \text { d.p.) }\end{array}$ & $\begin{array}{c}\text { Incerteza Expandida } \\
\mathrm{U}\left(\mathrm{mg} \mathrm{kg}^{-1}\right)\end{array}$ \\
\hline 14 & $5,6 \pm 0,1$ & $\pm 0,8$ \\
\hline 36 & $18,6 \pm 0,3$ & $\pm 2,6$ \\
\hline 38 & $8,0 \pm 0,1$ & $\pm 1,1$ \\
\hline 43 & $5,7 \pm 0,1$ & $\pm 0,8$ \\
\hline 52 & $12,3 \pm 0,5$ & $\pm 1,7$ \\
\hline $\begin{array}{l}\text { Comunidade Nhamundá - } \\
\text { Código da amostra }\end{array}$ & $\begin{array}{l}\mathrm{Hg} \text { Total }\left(\mathrm{mg} \mathrm{kg}^{-1}\right) \\
\text { (média } \pm \text { d.p.) }\end{array}$ & $\begin{array}{c}\text { Incerteza Expandida } \\
\mathbf{U}\left(\mathrm{mg} \mathrm{kg}^{-1}\right)\end{array}$ \\
\hline 301 & $1,1 \pm 0,1$ & $\pm 0,2$ \\
\hline 305 & $10,5 \pm 0,2$ & $\pm 1,5$ \\
\hline 311 & $3,8 \pm 0,1$ & $\pm 0,5$ \\
\hline 331 & $3,8 \pm 0,1$ & $\pm 0,5$ \\
\hline 340 & $7,8 \pm 0,2$ & $\pm 1,1$ \\
\hline $\begin{array}{c}\text { SESI - Manaus } \\
\text { Código da amostra } \\
\end{array}$ & $\begin{array}{l}\mathrm{Hg}^{\mathrm{H}} \text { Total }\left(\mathrm{mg} \mathrm{kg}^{-1}\right) \\
\text { (média } \pm \text { d.p.) }\end{array}$ & $\begin{array}{c}\text { Incerteza Expandida } \\
\mathrm{U}\left(\mathrm{mg} \mathrm{kg}^{-1}\right)\end{array}$ \\
\hline 373 & $0,58 \pm 0,03$ & $\pm 0,08$ \\
\hline 374 & $1,08 \pm 0,02$ & $\pm 0,15$ \\
\hline 379 & $3,82 \pm 0,02$ & $\pm 0,53$ \\
\hline 386 & $2,43 \pm 0,03$ & $\pm 0,34$ \\
\hline
\end{tabular}




\section{ANEXO VI - Metilmercúrio em cabelos}

Tabela 22 - Teor de MeHg em cabelos, com os desvios padrões (s) e as incertezas expandidas para as comunidades do PNJ

\begin{tabular}{|c|c|c|}
\hline $\begin{array}{c}\text { Comunidade Cachoeira - } \\
\text { Código da amostra }\end{array}$ & $\begin{array}{l}\text { MeHg }\left(\mathrm{mg} \mathrm{kg}^{-1}\right) \\
\text { (média } \pm \text { d.p.) }\end{array}$ & $\begin{array}{c}\text { Incerteza Expandida } \\
\mathbf{U}\left(\mathrm{mg} \mathrm{kg}^{-1}\right)\end{array}$ \\
\hline 29 & $39,6 \pm 0,2$ & $\pm 5,5$ \\
\hline 30 & $28,9 \pm 0,2$ & $\pm 4,0$ \\
\hline 37 & $55,8 \pm 0,4$ & $\pm 7,8$ \\
\hline $\begin{array}{l}\text { Comunidade Santo Elias - } \\
\text { Código da amostra }\end{array}$ & $\begin{array}{l}\text { MeHg }\left(\mathrm{mg} \mathrm{kg}^{-1}\right) \\
\text { (média } \pm \text { d.p.) }\end{array}$ & $\begin{array}{c}\text { Incerteza Expandida } \\
\mathbf{U}\left(\mathrm{mg} \mathrm{kg}^{-1}\right)\end{array}$ \\
\hline 128 & $28,3 \pm 0,3$ & $\pm 3,9$ \\
\hline 135 & $57,2 \pm 0,4$ & $\pm 8,0$ \\
\hline 147 & $45,1 \pm 0,2$ & $\pm 6,3$ \\
\hline 155 & $64,1 \pm 0,1$ & $\pm 8,9$ \\
\hline 166 & $59,5 \pm 0,3$ & $\pm 8,3$ \\
\hline 187 & $74,4 \pm 0,6$ & $\pm 10,4$ \\
\hline $\begin{array}{l}\text { Comunidade Seringalzinho } \\
\text { Código da amostra }\end{array}$ & $\begin{array}{l}\text { MeHg (mg kg-1) } \\
\text { (média } \pm \text { d.p.) }\end{array}$ & $\begin{array}{c}\text { Incerteza Expandida } \\
\mathrm{U}\left(\mathrm{mg} \mathrm{kg}^{-1}\right) \\
\end{array}$ \\
\hline 161 & $47,6 \pm 0,2$ & $\pm 6,7$ \\
\hline 189 & $20,6 \pm 0,1$ & $\pm 2,9$ \\
\hline 192 & $73,3 \pm 0,4$ & $\pm 10,3$ \\
\hline $\begin{array}{c}\text { Comunidade Vista Alegre - } \\
\text { Código da amostra }\end{array}$ & $\begin{array}{l}\text { MeHg }\left(\mathrm{mg} \mathrm{kg}^{-1}\right) \\
\text { (média } \pm \text { d.p.) }\end{array}$ & $\begin{array}{c}\text { Incerteza Expandida } \\
\mathrm{U}\left(\mathrm{mg} \mathrm{kg}^{-1}\right) \\
\end{array}$ \\
\hline 60 & $59,8 \pm 0,6$ & $\pm 8,4$ \\
\hline 71 & $41,4 \pm 0,8$ & $\pm 5,8$ \\
\hline 119 & $35,8 \pm 0,3$ & $\pm 5,0$ \\
\hline
\end{tabular}




\section{ANEXO VII - Metilmercúrio em cabelos}

Tabela 23 - Teor de MeHg em cabelos, com os desvios padrões (s) e as incertezas expandidas para as demais comunidades da região Amazônica

\begin{tabular}{|c|c|c|}
\hline $\begin{array}{c}\text { Comunidade Ajuricaba - } \\
\text { Código da amostra }\end{array}$ & $\begin{array}{l}\text { MeHg }\left(\mathrm{mg} \mathrm{kg}^{-1}\right) \\
\text { (média } \pm \text { d.p.) }\end{array}$ & $\begin{array}{c}\text { Incerteza Expandida } \\
\mathbf{U}\left(\mathrm{mg} \mathrm{kg}^{-1}\right)\end{array}$ \\
\hline 07 & $21,3 \pm 0,4$ & $\pm 2,9$ \\
\hline 15 & $9,92 \pm 0,05$ & $\pm 1,4$ \\
\hline 16 & $2,6 \pm 0,3$ & $\pm 0,4$ \\
\hline $\begin{array}{c}\text { Comunidade Alvarães } \\
\text { Código da amostra }\end{array}$ & $\begin{array}{l}\text { MeHg }\left(\mathrm{mg} \mathrm{kg}^{-1}\right) \\
\text { (média } \pm \text { d.p.) }\end{array}$ & $\begin{array}{c}\text { Incerteza Expandida } \\
\mathrm{U}\left(\mathrm{mg} \mathrm{kg}^{-1}\right)\end{array}$ \\
\hline 09 & $1,3 \pm 0,1$ & $\pm 0,2$ \\
\hline 10 & $2,03 \pm 0,05$ & $\pm 0,3$ \\
\hline 12 & $2,8 \pm 0,1$ & $\pm 0,4$ \\
\hline 13 & $2,1 \pm 0,1$ & $\pm 0,3$ \\
\hline 16 & $9,9 \pm 0,1$ & $\pm 1,4$ \\
\hline $\begin{array}{c}\text { Comunidade Borba - } \\
\text { Código da amostra }\end{array}$ & $\begin{array}{l}\text { MeHg }\left(\mathrm{mg} \mathrm{kg}^{-1}\right) \\
\text { (média } \pm \text { d.p.) }\end{array}$ & $\begin{array}{c}\text { Incerteza Expandida } \\
\mathbf{U}\left(\mathrm{mg} \mathrm{kg}^{-1}\right)\end{array}$ \\
\hline 78 & $4,93 \pm 0,05$ & $\pm 0,7$ \\
\hline 130 & $3,6 \pm 0,1$ & $\pm 0,5$ \\
\hline 140 & $10,1 \pm 0,2$ & $\pm 1,4$ \\
\hline 278 & $1,51 \pm 0,01$ & $\pm 0,2$ \\
\hline 338 & $5,64 \pm 0,02$ & $\pm 0,8$ \\
\hline $\begin{array}{c}\text { Comunidade Itapiranga - } \\
\text { Código da amostra } \\
\end{array}$ & $\begin{array}{l}\text { MeHg }\left(\mathrm{mg} \mathrm{kg}^{-1}\right) \\
\text { (média } \pm \text { d.p.) }\end{array}$ & $\begin{array}{c}\text { Incerteza Expandida } \\
\mathrm{U}\left(\mathrm{mg} \mathrm{kg}^{-1}\right) \\
\end{array}$ \\
\hline 58 & $9,9 \pm 0,2$ & $\pm 1,4$ \\
\hline 63 & $4,4 \pm 0,6$ & $\pm 0,6$ \\
\hline 68 & $2,3 \pm 0,1$ & $\pm 0,3$ \\
\hline 71 & $1,35 \pm 0,04$ & $\pm 0,2$ \\
\hline 157 & $1,34 \pm 0,03$ & $\pm 0,2$ \\
\hline 262 & $3,4 \pm 0,5$ & $\pm 0,5$ \\
\hline $\begin{array}{c}\text { Comunidade Nhamundá - } \\
\text { Código da amostra }\end{array}$ & $\begin{array}{l}\text { MeHg }\left(\mathrm{mg} \mathrm{kg}^{-1}\right) \\
\text { (média } \pm \text { d.p.) }\end{array}$ & $\begin{array}{c}\text { Incerteza Expandida } \\
\mathbf{U}\left(\mathrm{mg} \mathrm{kg}^{-1}\right)\end{array}$ \\
\hline 302 & $2,1 \pm 0,1$ & $\pm 0,3$ \\
\hline 310 & $2,0 \pm 0,1$ & $\pm 0,3$ \\
\hline 314 & $1,5 \pm 0,1$ & $\pm 0,2$ \\
\hline 330 & $1,88 \pm 0,03$ & $\pm 0,3$ \\
\hline $\begin{array}{l}\text { Comunidade SESI - } \\
\text { Código da amostra }\end{array}$ & $\begin{array}{l}\text { MeHg }\left(\mathrm{mg} \mathrm{kg}^{-1}\right) \\
\text { (média } \pm \text { d.p.) }\end{array}$ & $\begin{array}{c}\text { Incerteza Expandida } \\
\mathrm{U}\left(\mathrm{mg} \mathrm{kg}^{-1}\right)\end{array}$ \\
\hline 363 & $2,66 \pm 0,02$ & $\pm 0,4$ \\
\hline 380 & $2,06 \pm 0,01$ & $\pm 0,3$ \\
\hline 401 & $3,84 \pm 0,03$ & $\pm 0,5$ \\
\hline 402 & $2,99 \pm 0,02$ & $\pm 0,5$ \\
\hline
\end{tabular}




\section{ANEXO VIII - Mercúrio total em peixes}

Tabela 25 - Teor de Hg total em espécies de peixes comumente consumidas pela população da cidade de Manaus e comunidades próximas

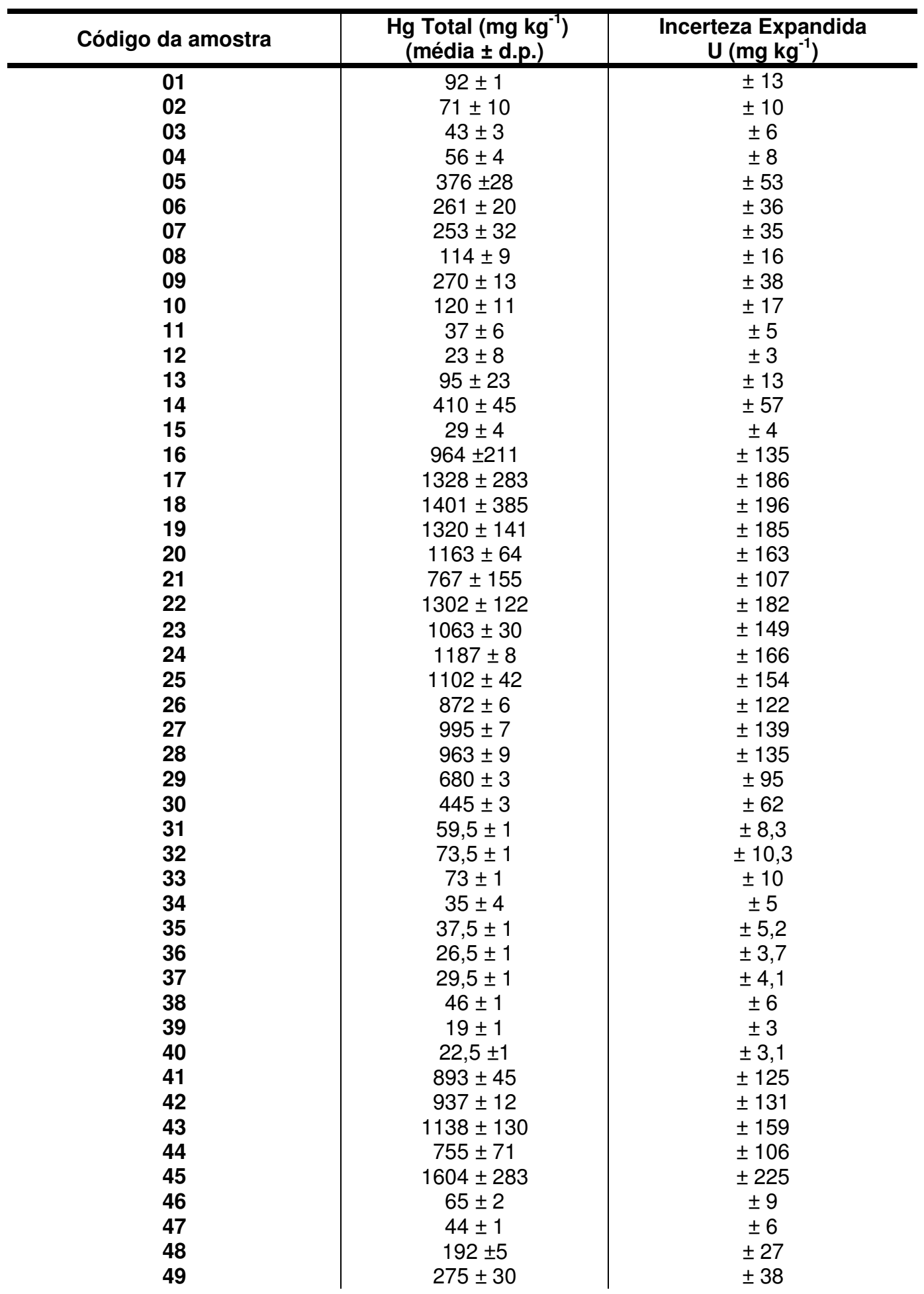




\begin{tabular}{c|c|c}
$\mathbf{5 0}$ & $293 \pm 6$ & \pm 41 \\
$\mathbf{5 1}$ & $1508 \pm 70$ & \pm 211 \\
$\mathbf{5 2}$ & $2392 \pm 352$ & \pm 335 \\
$\mathbf{5 3}$ & $1674 \pm 209$ & \pm 234 \\
$\mathbf{5 4}$ & $588 \pm 30$ & \pm 82 \\
$\mathbf{5 5}$ & $131 \pm 13$ & \pm 18 \\
$\mathbf{5 6}$ & $194 \pm 22$ & \pm 27 \\
$\mathbf{5 7}$ & $117 \pm 6$ & \pm 16 \\
$\mathbf{5 8}$ & $161 \pm 11$ & \pm 22 \\
$\mathbf{5 9}$ & $133 \pm 9$ & \pm 19 \\
$\mathbf{6 0}$ & $149 \pm 21$ & \pm 21 \\
$\mathbf{6 1}$ & $151 \pm 9$ & \pm 21 \\
$\mathbf{6 2}$ & $642 \pm 49$ & \pm 90 \\
$\mathbf{6 3}$ & $129 \pm 15$ & \pm 18 \\
$\mathbf{6 4}$ & $101 \pm 10$ & \pm 14 \\
\hline
\end{tabular}




\section{ANEXO IX - Mercúrio em cabelos}

Tabela 27 - Teor de $\mathrm{Hg}$ total em cabelos, com os desvios padrões e as incertezas expandidas para os bairros Alvorada e Cidade Nova, Manaus

\begin{tabular}{|c|c|c|}
\hline $\begin{array}{l}\text { Comunidade Alvorada } \\
\text { Código da amostra }\end{array}$ & $\begin{array}{l}\text { Hg Total }\left(\mathrm{mg} \mathrm{kg}^{-1}\right) \\
\text { (média } \pm \text { d.p.) }\end{array}$ & $\begin{array}{c}\text { Incerteza Expandida } \\
\mathbf{U}\left(\mathrm{mg} \mathrm{kg}^{-1}\right)\end{array}$ \\
\hline $\begin{array}{c}1 \\
2 \\
3 \\
4 \\
5 \\
6 \\
7 \\
8 \\
9 \\
10 \\
11 \\
12 \\
13 \\
14 \\
15 \\
16 \\
17 \\
18 \\
19 \\
20 \\
21 \\
22 \\
\end{array}$ & $\begin{array}{c}1,40 \pm 0,04 \\
0,73 \pm 0,05 \\
0,76 \pm 0,05 \\
0,65 \pm 0,03 \\
1,73 \pm 0,04 \\
1,02 \pm 0,05 \\
0,29 \pm 0,01 \\
2,8 \pm 0,1 \\
1,22 \pm 0,05 \\
4,6 \pm 0,2 \\
18,3 \pm 0,1 \\
0,64 \pm 0,02 \\
1,11 \pm 0,04 \\
0,53 \pm 0,01 \\
6,0 \pm 0,2 \\
0,50 \pm 0,01 \\
1,29 \pm 0,04 \\
1,23 \pm 0,03 \\
2,0 \pm 0,1 \\
0,47 \pm 0,01 \\
1,60 \pm 0,05 \\
1,6 \pm 0,1\end{array}$ & $\begin{array}{c} \pm 0,20 \\
\pm 0,10 \\
\pm 0,11 \\
\pm 0,09 \\
\pm 0,24 \\
\pm 0,14 \\
\pm 0,04 \\
\pm 0,4 \\
\pm 0,17 \\
\pm 0,6 \\
\pm 2,6 \\
\pm 0,09 \\
\pm 0,15 \\
\pm 0,07 \\
\pm 0,8 \\
\pm 0,07 \\
\pm 0,18 \\
\pm 0,17 \\
\pm 0,3 \\
\pm 0,07 \\
\pm 0,22 \\
\pm 0,2\end{array}$ \\
\hline $\begin{array}{c}\text { Comunidade Cidade Nova } \\
\text { Código da amostra }\end{array}$ & $\begin{array}{l}\text { Hg Total }\left(\mathrm{mg} \mathrm{kg}^{-1}\right) \\
\text { (média } \pm \text { d.p.) }\end{array}$ & $\begin{array}{c}\text { Incerteza Expandida } \\
\mathrm{U}\left(\mathrm{mg} \mathrm{kg}^{-1}\right)\end{array}$ \\
\hline $\begin{array}{c}96 \\
97 \\
98 \\
99 \\
100 \\
101 \\
102 \\
103 \\
104 \\
105 \\
106 \\
107 \\
108 \\
109 \\
110 \\
111 \\
112 \\
113 \\
114 \\
115 \\
116 \\
117 \\
118 \\
119 \\
120 \\
121 \\
122 \\
123 \\
124 \\
125 \\
126 \\
\end{array}$ & $\begin{array}{c}2,21 \pm 0,05 \\
2,8 \pm 0,1 \\
1,9 \pm 0,1 \\
5,4 \pm 0,1 \\
0,50 \pm 0,01 \\
1,46 \pm 0,05 \\
3,3 \pm 0,1 \\
0,61 \pm 0,01 \\
0,64 \pm 0,01 \\
<L D \\
0,61 \pm 0,01 \\
3,5 \pm 0,1 \\
3,1 \pm 0,1 \\
0,62 \pm 0,01 \\
1,7 \pm 0,1 \\
3,94 \pm 0,05 \\
2,79 \pm 0,04 \\
1,48 \pm 0,05 \\
1,19 \pm 0,03 \\
0,41 \pm 0,01 \\
2,34 \pm 0,04 \\
1,71 \pm 0,03 \\
20,1 \pm 0,2 \\
1,58 \pm 0,03 \\
9,4 \pm 0,4 \\
2,12 \pm 0,02 \\
0,11 \pm 0,01 \\
0,56 \pm 0,01 \\
<L D \\
4,3 \pm 0,1 \\
0,36 \pm 0,01 \\
\end{array}$ & $\begin{array}{c} \pm 0,31 \\
\pm 0,4 \\
\pm 0,3 \\
\pm 0,8 \\
\pm 0,07 \\
\pm 0,20 \\
\pm 0,5 \\
\pm 0,08 \\
\pm 0,09 \\
- \\
\pm 0,08 \\
\pm 0,5 \\
\pm 0,4 \\
\pm 0,09 \\
\pm 0,2 \\
\pm 0,55 \\
\pm 0,39 \\
\pm 0,21 \\
\pm 0,17 \\
\pm 0,06 \\
\pm 0,33 \\
\pm 0,24 \\
\pm 2,8 \\
\pm 0,22 \\
\pm 1,3 \\
\pm 0,30 \\
\pm 0,02 \\
\pm 0,08 \\
- \\
\pm 0,6 \\
\pm 0,05 \\
\end{array}$ \\
\hline
\end{tabular}

$*<\mathrm{LD}$ - valor menor que o limite de deteção. 


\section{ANEXO X - Mercúrio em cabelos}

Tabela 28 - Teor de $\mathrm{Hg}$ total em cabelos, com os desvios padrões e as incertezas expandidas para o bairro Compensa, Manaus

\begin{tabular}{|c|c|c|}
\hline $\begin{array}{l}\text { Comunidade Compensa } \\
\text { Código da amostra }\end{array}$ & $\begin{array}{l}\text { Hg Total }\left(\mathrm{mg} \mathrm{kg}^{-1}\right) \\
\text { (média } \pm \text { d.p.) }\end{array}$ & $\begin{array}{c}\text { Incerteza Expandida } \\
\mathrm{U}\left(\mathrm{mg} \mathrm{kg}^{-1}\right)\end{array}$ \\
\hline 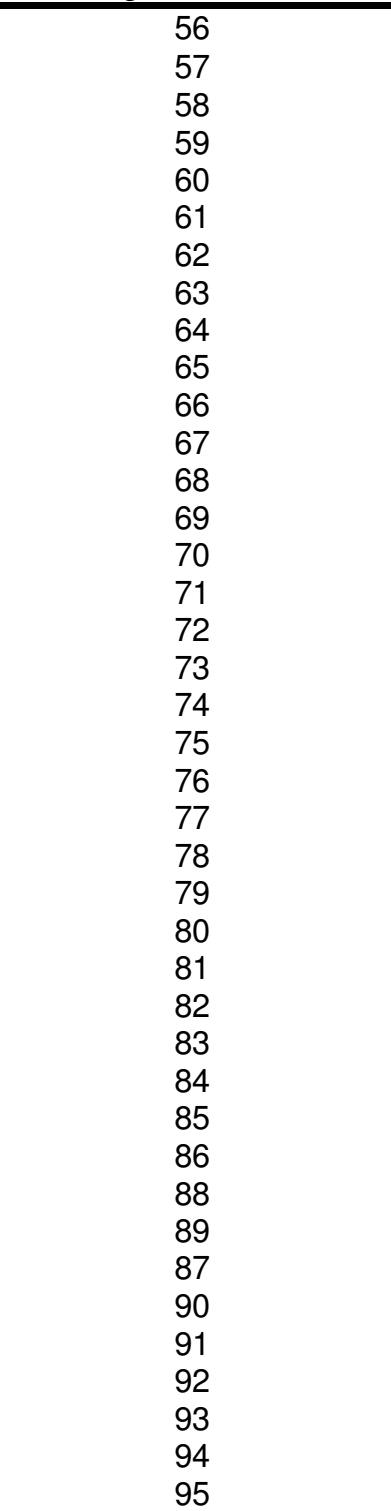 & $\begin{array}{c}3,90 \pm 0,04 \\
1,6 \pm 0,1 \\
1,64 \pm 0,05 \\
8,64 \pm 0,4 \\
1,26 \pm 0,05 \\
0,91 \pm 0,04 \\
2,39 \pm 0,05 \\
1,18 \pm 0,05 \\
1,16 \pm 0,03 \\
2,9 \pm 0,1 \\
3,0 \pm 0,1 \\
0,51 \pm 0,01 \\
1,52 \pm 0,05 \\
0,18 \pm 0,01 \\
0,08 \pm 0,04 \\
0,60 \pm 0,02 \\
1,33 \pm 0,05 \\
4,3 \pm 0,1 \\
0,75 \pm 0,04 \\
0,63 \pm 0,03 \\
1,47 \pm 0,05 \\
2,4 \pm 0,1 \\
0,44 \pm 0,02 \\
0,25 \pm 0,01 \\
0,089 \pm 0,001 \\
0,16 \pm 0,01 \\
1,2 \pm 0,01 \\
3,5 \pm 0,1 \\
<\mathrm{LD} \\
0,84 \pm 0,05 \\
1,12 \pm 0,04 \\
0,72 \pm 0,05 \\
0,48 \pm 0,01 \\
1,37 \pm 0,04 \\
<\mathrm{LD} \\
1,75 \pm 0,03 \\
0,55 \pm 0,01 \\
0,24 \pm 0,01 \\
<\mathrm{LD} \\
1,28 \pm 0,05\end{array}$ & $\begin{array}{l} \pm 0,55 \\
\pm 0,2 \\
\pm 0,23 \\
\pm 1,2 \\
\pm 0,18 \\
\pm 0,13 \\
\pm 0,33 \\
\pm 0,16 \\
\pm 0,16 \\
\pm 0,4 \\
\pm 0,4 \\
\pm 0,07 \\
\pm 0,21 \\
\pm 0,02 \\
\pm 0,11 \\
\pm 0,08 \\
\pm 0,19 \\
\pm 0,6 \\
\pm 0,10 \\
\pm 0,09 \\
\pm 0,20 \\
\pm 0,3 \\
\pm 0,06 \\
\pm 0,04 \\
\pm 0,012 \\
\pm 0,02 \\
\pm 0,17 \\
\pm 0,5 \\
- \\
\pm 0,12 \\
\pm 0,16 \\
\pm 0,10 \\
\pm 0,07 \\
\pm 0,19 \\
\\
\pm 0,24 \\
\pm 0,08 \\
\pm 0,03 \\
- \\
\pm 0,18\end{array}$ \\
\hline
\end{tabular}

* <LD - valor menor que o limite de deteção. 


\section{ANEXO XI - Mercúrio em cabelos}

Tabela 29 - Teor de $\mathrm{Hg}$ total em cabelos, com os desvios padrões e as incertezas expandidas para o bairro Flores, Manaus

\begin{tabular}{c|c|c}
\hline $\begin{array}{c}\text { Comunidade Flores } \\
\text { Código da amostra }\end{array}$ & $\begin{array}{c}\left.\text { Hg Total } \mathbf{~ m g ~ k g ~}^{-1}\right) \\
\text { (média } \pm \text { d.p.) }\end{array}$ & $\begin{array}{c}\text { Incerteza Expandida } \\
\mathbf{U}\left(\mathbf{m g ~ k g}^{-1}\right)\end{array}$ \\
\hline 23 & $34,4 \pm 0,3$ & $\pm 4,8$ \\
24 & $30,0 \pm 0,2$ & $\pm 4,2$ \\
25 & $0,42 \pm 0,01$ & $\pm 0,59$ \\
26 & $2,0 \pm 0,1$ & $\pm 0,3$ \\
27 & $0,53 \pm 0,01$ & $\pm 0,07$ \\
28 & $1,0 \pm 0,1$ & $\pm 0,1$ \\
29 & $2,25 \pm 0,03$ & $\pm 0,31$ \\
30 & $0,97 \pm 0,04$ & $\pm 0,14$ \\
31 & $3,53 \pm 0,05$ & $\pm 0,49$ \\
32 & $0,91 \pm 0,05$ & $\pm 0,13$ \\
33 & $0,80 \pm 0,03$ & $\pm 0,11$ \\
34 & $0,56 \pm 0,01$ & $\pm 0,08$ \\
35 & $1,65 \pm 0,05$ & $\pm 0,23$ \\
36 & $0,24 \pm 0,01$ & $\pm 0,03$ \\
37 & $1,34 \pm 0,03$ & $\pm 0,19$ \\
38 & $3,9 \pm 0,1$ & $\pm 0,5$ \\
39 & $1,62 \pm 0,04$ & $\pm 0,23$ \\
40 & $3,12 \pm 0,05$ & $\pm 0,44$ \\
41 & $1,4 \pm 0,1$ & $\pm 0,2$ \\
42 & $0,35 \pm 0,02$ & $\pm 0,05$ \\
43 & $0,82 \pm 0,05$ & $\pm 0,11$ \\
44 & $0,20 \pm 0,01$ & $\pm 0,03$ \\
45 & $0,44 \pm 0,02$ & $\pm 0,06$ \\
46 & $0,80 \pm 0,03$ & $\pm 0,13$ \\
47 & $2,60 \pm 0,02$ & $\pm 0,36$ \\
48 & $1,91 \pm 0,04$ & $\pm 0,28$ \\
49 & $0,50 \pm 0,03$ & $\pm 0,07$ \\
50 & $1,86 \pm 0,03$ & $\pm 0,26$ \\
51 & $0,34 \pm 0,02$ & $\pm 0,05$ \\
52 & $0,20 \pm 0,01$ & $\pm 0,03$ \\
53 & $1,14 \pm 0,05$ & $\pm 0,16$ \\
54 & $3,96 \pm 0,04$ & $\pm 0,55$ \\
55 & $0,48 \pm 0,02$ & $\pm 0,07$ \\
\hline
\end{tabular}




\section{ANEXO XII - Mercúrio em cabelos}

Tabela 30 - Teor de Hg total em cabelos, com os desvios padrões e as incertezas expandidas para o bairro Japiim, Manaus

\begin{tabular}{|c|c|c|}
\hline $\begin{array}{l}\text { Comunidade Japiim } \\
\text { Código da amostra }\end{array}$ & $\begin{array}{l}\text { Hg Total (mg kg }{ }^{-1} \text { ) } \\
\text { (média } \pm \text { d.p.) }\end{array}$ & $\begin{array}{c}\text { Incerteza Expandida } \\
\mathbf{U}\left(\mathrm{mg} \mathrm{kg}^{-1}\right)\end{array}$ \\
\hline 158 & $0,39 \pm 0,01$ & $\pm 0,05$ \\
\hline 159 & $0,12 \pm 0,01$ & $\pm 0,02$ \\
\hline 160 & $0,63 \pm 0,01$ & $\pm 0,09$ \\
\hline 161 & $0,31 \pm 0,01$ & $\pm 0,04$ \\
\hline 162 & $2,7 \pm 0,1$ & $\pm 0,4$ \\
\hline 163 & $0,86 \pm 0,05$ & $\pm 0,12$ \\
\hline 164 & $0,19 \pm 0,01$ & $\pm 0,03$ \\
\hline 165 & $0,65 \pm 0,01$ & $\pm 0,09$ \\
\hline 166 & $<\mathrm{LD}$ & - \\
\hline 167 & $1,23 \pm 0,03$ & $\pm 0,17$ \\
\hline 168 & $3,25 \pm 0,04$ & $\pm 0,45$ \\
\hline 169 & $0,14 \pm 0,01$ & $\pm 0,02$ \\
\hline 170 & $0,07 \pm 0,01$ & $\pm 0,01$ \\
\hline 171 & $<\mathrm{LD}$ & - \\
\hline 172 & $<\mathrm{LD}$ & - \\
\hline 173 & $0,87 \pm 0,05$ & $\pm 0,12$ \\
\hline 174 & $1,1 \pm 0,1$ & $\pm 0,1$ \\
\hline 175 & $1,8 \pm 0,1$ & $\pm 0,2$ \\
\hline 176 & $0,65 \pm 0,01$ & $\pm 0,09$ \\
\hline 177 & $4,8 \pm 0,2$ & $\pm 0,7$ \\
\hline 178 & $1,2 \pm 0,1$ & $\pm 0,2$ \\
\hline 179 & $1,15 \pm 0,04$ & $\pm 0,16$ \\
\hline 180 & $0,34 \pm 0,02$ & $\pm 0,05$ \\
\hline 181 & $0,77 \pm 0,05$ & $\pm 0,11$ \\
\hline 182 & $0,055 \pm 0,004$ & $\pm 0,008$ \\
\hline 183 & $1,62 \pm 0,03$ & $\pm 0,23$ \\
\hline 184 & $1,12 \pm 0,03$ & $\pm 0,16$ \\
\hline 185 & $0,93 \pm 0,02$ & $\pm 0,13$ \\
\hline 186 & $2,0 \pm 0,1$ & $\pm 0,3$ \\
\hline 187 & $3,4 \pm 0,1$ & $\pm 0,5$ \\
\hline 188 & $1,2 \pm 0,1$ & $\pm 0,2$ \\
\hline 189 & $0,9 \pm 0,1$ & $\pm 0,1$ \\
\hline 190 & $7,14 \pm 0,05$ & $\pm 1,01$ \\
\hline 191 & $<\mathrm{LD}$ & - \\
\hline 192 & $<\mathrm{LD}$ & - \\
\hline 193 & $0,65 \pm 0,01$ & $\pm 0,09$ \\
\hline 194 & $0,69 \pm 0,05$ & $\pm 0,10$ \\
\hline 195 & $0,78 \pm 0,03$ & $\pm 0,11$ \\
\hline 196 & $0,13 \pm 0,01$ & $\pm 0,02$ \\
\hline 197 & $<\mathrm{LD}$ & - \\
\hline 198 & $2,8 \pm 0,1$ & $\pm 0,4$ \\
\hline 199 & $2,0 \pm 0,1$ & $\pm 0,3$ \\
\hline 200 & $2,0 \pm 0,1$ & $\pm 0,3$ \\
\hline 201 & $0,39 \pm 0,01$ & $\pm 0,05$ \\
\hline 202 & $0,13 \pm 0,01$ & $\pm 0,02$ \\
\hline
\end{tabular}

$*<\mathrm{LD}$ - valor menor que o limite de deteção. 


\section{ANEXO XIII - Mercúrio em cabelos}

Tabela 31 - Teor de $\mathrm{Hg}$ total em cabelos, com os desvios padrões e as incertezas expandidas para o bairro São José, Manaus

\begin{tabular}{|c|c|c|}
\hline $\begin{array}{l}\text { Comunidade São José } \\
\text { Código da amostra }\end{array}$ & $\begin{array}{l}\mathrm{Hg}^{\mathrm{Hg}} \text { Total }\left(\mathrm{mg} \mathrm{kg}^{-1}\right) \\
\text { (média } \pm \text { d.p.) }\end{array}$ & $\begin{array}{c}\text { Incerteza Expandida } \\
\mathrm{U}\left(\mathrm{mg} \mathrm{kg}^{-1}\right)\end{array}$ \\
\hline 127 & $1,25 \pm 0,03$ & $\pm 0,17$ \\
\hline 129 & $0,08 \pm 0,01$ & $\pm 0,01$ \\
\hline 130 & $0,06 \pm 0,01$ & $\pm 0,01$ \\
\hline 131 & $0,07 \pm 0,01$ & $\pm 0,01$ \\
\hline 132 & $0,12 \pm 0,01$ & $\pm 0,02$ \\
\hline 133 & $0,18 \pm 0,01$ & $\pm 0,03$ \\
\hline 134 & $0,16 \pm 0,01$ & $\pm 0,02$ \\
\hline 135 & $0,07 \pm 0,01$ & $\pm 0,01$ \\
\hline 136 & $0,07 \pm 0,01$ & $\pm 0,01$ \\
\hline 137 & $<\mathrm{LD}$ & - \\
\hline 138 & $<L D$ & - \\
\hline 139 & $<L D$ & - \\
\hline 143 & $<\mathrm{LD}$ & - \\
\hline 144 & $0,47 \pm 0,01$ & $\pm 0,07$ \\
\hline 145 & $0,06 \pm 0,01$ & $\pm 0,01$ \\
\hline 146 & $0,07 \pm 0,01$ & $\pm 0,01$ \\
\hline 147 & $<\mathrm{LD}$ & - \\
\hline 148 & $<\mathrm{LD}$ & - \\
\hline 149 & $0,65 \pm 0,02$ & $\pm 0,09$ \\
\hline 150 & $0,28 \pm 0,02$ & $\pm 0,04$ \\
\hline 157 & $2,1 \pm 0,1$ & $\pm 0,3$ \\
\hline 128 & $0,06 \pm 0,01$ & $\pm 0,01$ \\
\hline 140 & $0,06 \pm 0,01$ & $\pm 0,01$ \\
\hline 141 & $0,07 \pm 0,01$ & $\pm 0,01$ \\
\hline 142 & $0,06 \pm 0,01$ & $\pm 0,01$ \\
\hline 151 & $1,03 \pm 0,08$ & $\pm 0,14$ \\
\hline 152 & $2,5 \pm 0,1$ & $\pm 0,3$ \\
\hline 153 & $2,9 \pm 0,1$ & $\pm 0,4$ \\
\hline 154 & $0,81 \pm 0,05$ & $\pm 0,11$ \\
\hline 155 & $4,7 \pm 0,2$ & $\pm 0,6$ \\
\hline 156 & $0,52 \pm 0,01$ & $\pm 0,07$ \\
\hline
\end{tabular}

* <LD - valor menor que o limite de deteção. 


\section{ANEXO XIV - Metilmercúrio em cabelos}

Tabela 32 - Teor de MeHg em cabelos, com os desvios padrões e as incertezas expandidas para os bairros Alvada e Cidade Nova, Manaus

\begin{tabular}{|c|c|c|}
\hline $\begin{array}{c}\text { Alvorada } \\
\text { Código da amostra }\end{array}$ & $\begin{array}{c}\text { MeHg }\left(\mathrm{mg} \mathrm{kg}^{-1}\right) \\
\text { (média } \pm \text { d.p.) }\end{array}$ & $\begin{array}{c}\text { Incerteza Expandida } \\
\mathrm{U}\left(\mathrm{mg} \mathrm{kg}^{-1}\right)\end{array}$ \\
\hline $\begin{array}{c}1 \\
2 \\
3 \\
4 \\
5 \\
6 \\
7 \\
8 \\
9 \\
10 \\
11 \\
12 \\
13 \\
14 \\
15 \\
16 \\
17 \\
18 \\
19 \\
20 \\
21 \\
22 \\
\end{array}$ & $\begin{array}{c}1,12 \pm 0,04 \\
0,19 \pm 0,02 \\
0,72 \pm 0,05 \\
0,36 \pm 0,03 \\
1,33 \pm 0,06 \\
\text { ND } \\
\text { ND } \\
1,8 \pm 0,1 \\
0,90 \pm 0,04 \\
3,7 \pm 0,1 \\
18 \pm 1 \\
\text { ND } \\
0,56 \pm 0,04 \\
<L D \\
4,9 \pm 0,4 \\
0,43 \pm 0,02 \\
0,95 \pm 0,07 \\
\text { ND } \\
1,9 \pm 0,1 \\
0,22 \pm 0,01 \\
1,3 \pm 0,1 \\
1,4 \pm 0,1\end{array}$ & $\begin{array}{c} \pm 0,16 \\
\pm 0,03 \\
\pm 0,10 \\
\pm 0,05 \\
\pm 0,19 \\
- \\
- \\
\pm 0,3 \\
\pm 0,13 \\
\pm 0,5 \\
\pm 2 \\
- \\
\pm 0,08 \\
- \\
\pm 0,7 \\
\pm 0,06 \\
\pm 0,13 \\
- \\
\pm 0,3 \\
\pm 0,03 \\
\pm 0,2 \\
\pm 0,2\end{array}$ \\
\hline $\begin{array}{c}\text { Cidade Nova } \\
\text { Código da amostra }\end{array}$ & $\begin{array}{c}\left.\text { MeHg (mg kg }{ }^{-1}\right) \\
\text { (média } \pm \text { d.p.) }\end{array}$ & $\begin{array}{c}\text { Incerteza Expandida } \\
\mathrm{U}\left(\mathrm{mg} \mathrm{kg}^{-1}\right)\end{array}$ \\
\hline $\begin{array}{c}97 \\
96 \\
98 \\
99 \\
100 \\
101 \\
102 \\
103 \\
104 \\
105 \\
106 \\
107 \\
108 \\
109 \\
110 \\
111 \\
112 \\
113 \\
114 \\
115 \\
116 \\
117 \\
118 \\
119 \\
120 \\
121 \\
122\end{array}$ & $\begin{array}{c}1,8 \pm 0,1 \\
1,4 \pm 0,1 \\
\text { ND } \\
4,7 \pm 0,4 \\
\text { ND } \\
\text { ND } \\
2,2 \pm 0,1 \\
0,57 \pm 0,03 \\
\text { ND } \\
<\mathrm{LD} \\
\text { ND } \\
3,0 \pm 0,3 \\
2,1 \pm 0,2 \\
\text { ND } \\
\text { ND } \\
2,8 \pm 0,3 \\
1,3 \pm 0,1 \\
0,80 \pm 0,04 \\
\text { ND } \\
<\mathrm{LD} \\
1,09 \pm 0,07 \\
1,08 \pm 0,05 \\
13 \pm 1 \\
1,2 \pm 0,1 \\
7,2 \pm 0,7 \\
1,1 \pm 0,1 \\
<\mathrm{LD}\end{array}$ & $\begin{array}{c} \pm 0,2 \\
\pm 0,2 \\
- \\
\pm 0,7 \\
- \\
- \\
\pm 0,3 \\
\pm 0,08 \\
- \\
- \\
- \\
\pm 0,4 \\
\pm 0,3 \\
- \\
- \\
\pm 0,4 \\
\pm 0,2 \\
\pm 0,11 \\
- \\
- \\
\pm 0,15 \\
\pm 0,15 \\
\pm 2 \\
\pm 0,2 \\
\pm 1,0 \\
\pm 0,1 \\
-\end{array}$ \\
\hline
\end{tabular}




\begin{tabular}{r|r|r}
\hline & & \\
123 & $<L D$ & - \\
124 & $<L D$ & - \\
125 & ND & - \\
126 & $<L D$ & - \\
\hline
\end{tabular}




\section{ANEXO XV - Metilmercúrio em cabelos}

Tabela 33 - Teor de MeHg em cabelos, com os desvios padrões e as incertezas expandidas para o bairro Compensa, Manaus

\begin{tabular}{|c|c|c|}
\hline $\begin{array}{c}\text { Comunidade Compensa } \\
\text { Código da amostra }\end{array}$ & $\begin{array}{c}\text { MeHg }\left(\mathrm{mg} \mathrm{kg}^{-1}\right) \\
(\text { média } \pm \text { d.p.) }\end{array}$ & $\begin{array}{c}\text { Incerteza Expandida } \\
U\left(\mathrm{mg} \mathrm{kg}^{-1}\right)\end{array}$ \\
\hline 56 & $2,9 \pm 0,3$ & $\pm 0,4$ \\
\hline 57 & $1,2 \pm 0,2$ & $\pm 0,2$ \\
\hline 58 & $1,2 \pm 0,2$ & $\pm 0,2$ \\
\hline 59 & $5,2 \pm 0,4$ & $\pm 0,7$ \\
\hline 60 & $1,2 \pm 0,1$ & $\pm 0,2$ \\
\hline 61 & $0,55 \pm 0,03$ & $\pm 0,08$ \\
\hline 62 & $1,63 \pm 0,05$ & $\pm 0,23$ \\
\hline 63 & $0,32 \pm 0,01$ & $\pm 0,05$ \\
\hline 64 & $0,85 \pm 0,04$ & $\pm 0,12$ \\
\hline 65 & $2,0 \pm 0,2$ & $\pm 0,3$ \\
\hline 66 & $1,7 \pm 0,1$ & $\pm 0,2$ \\
\hline 67 & $0,09 \pm 0,01$ & $\pm 0,01$ \\
\hline 68 & $1,34 \pm 0,05$ & $\pm 0,19$ \\
\hline 69 & $0,08 \pm 0,01$ & $\pm 0,01$ \\
\hline 70 & $0,05 \pm 0,01$ & $\pm 0,01$ \\
\hline 71 & ND & - \\
\hline 72 & $0,99 \pm 0,06$ & $\pm 0,14$ \\
\hline 73 & $2,2 \pm 0,1$ & $\pm 0,3$ \\
\hline 74 & ND & - \\
\hline 75 & ND & - \\
\hline 76 & $0,85 \pm 0,04$ & $\pm 0,12$ \\
\hline 77 & $1,6 \pm 0,1$ & $\pm 0,2$ \\
\hline 78 & ND & - \\
\hline 79 & $<L D$ & - \\
\hline 80 & $<L D$ & - \\
\hline 81 & $<\mathrm{LD}$ & - \\
\hline 82 & $0,93 \pm 0,04$ & $\pm 0,13$ \\
\hline 83 & $2,3 \pm 0,1$ & $\pm 0,3$ \\
\hline 84 & $<\mathrm{LD}$ & - \\
\hline 85 & $0,62 \pm 0,03$ & $\pm 0,09$ \\
\hline 86 & $0,86 \pm 0,04$ & $\pm 0,12$ \\
\hline 87 & $1,09 \pm 0,03$ & $\pm 0,15$ \\
\hline 88 & $0,51 \pm 0,02$ & $\pm 0,07$ \\
\hline 89 & ND & - \\
\hline 90 & $<\mathrm{LD}$ & - \\
\hline 91 & $0,84 \pm 0,02$ & $\pm 0,12$ \\
\hline 92 & ND & - \\
\hline 93 & $<L D$ & - \\
\hline 94 & $<\mathrm{LD}$ & - \\
\hline 95 & $1,0 \pm 0,1$ & $\pm 0,1$ \\
\hline
\end{tabular}

* <LD - valor menor que o limite de deteção.

* ND - não determinado. 


\section{ANEXO XVI - Metilmercúrio em cabelos}

Tabela 34 - Teor de MeHg em cabelos, com os desvios padrões (s) e as incertezas expandidas para o bairro Flores, Manaus

\begin{tabular}{|c|c|c|}
\hline $\begin{array}{l}\text { Comunidade Flores } \\
\text { Código da amostra }\end{array}$ & $\begin{array}{c}\text { MeHg }\left(\mathrm{mg} \mathrm{kg}^{-1}\right) \\
(\text { média } \pm \text { d.p.) }\end{array}$ & $\begin{array}{c}\text { Incerteza Expandida } \\
\mathbf{U}\left(\mathrm{mg} \mathrm{kg}^{-1}\right)\end{array}$ \\
\hline 23 & $18 \pm 1$ & \pm 2 \\
\hline 24 & $19 \pm 2$ & \pm 3 \\
\hline 25 & ND & - \\
\hline 26 & $1,2 \pm 0,1$ & $\pm 0,2$ \\
\hline 27 & ND & - \\
\hline 28 & $0,51 \pm 0,03$ & $\pm 0,07$ \\
\hline 29 & $1,7 \pm 0,1$ & $\pm 0,2$ \\
\hline 30 & $0,58 \pm 0,03$ & $\pm 0,08$ \\
\hline 31 & $3,0 \pm 0,1$ & $\pm 0,4$ \\
\hline 32 & $0,64 \pm 0,02$ & $\pm 0,09$ \\
\hline 33 & $0,60 \pm 0,03$ & $\pm 0,08$ \\
\hline 34 & ND & - \\
\hline 35 & $0,80 \pm 0,04$ & $\pm 0,11$ \\
\hline 36 & ND & - \\
\hline 37 & ND & - \\
\hline 38 & $2,9 \pm 0,3$ & $\pm 0,4$ \\
\hline 39 & ND & - \\
\hline 40 & $2,8 \pm 0,2$ & $\pm 0,4$ \\
\hline 41 & ND & - \\
\hline 42 & ND & - \\
\hline 43 & $0,53 \pm 0,02$ & $\pm 0,07$ \\
\hline 44 & $<\mathrm{LD}$ & - \\
\hline 45 & $<\mathrm{LD}$ & - \\
\hline 46 & $0,57 \pm 0,02$ & $\pm 0,08$ \\
\hline 47 & $1,26 \pm 0,05$ & $\pm 0,18$ \\
\hline 48 & ND & - \\
\hline 49 & ND & - \\
\hline 50 & $1,06 \pm 0,02$ & $\pm 0,15$ \\
\hline 51 & ND & - \\
\hline 52 & ND & - \\
\hline 53 & ND & - \\
\hline 54 & $3,1 \pm 0,3$ & $\pm 0,4$ \\
\hline 55 & ND & - \\
\hline
\end{tabular}




\section{ANEXO XVII - Metilmercúrio em cabelos}

Tabela 35 - Teor de MeHg em cabelos, com os desvios padrões e as incertezas expandidas para o bairro Japiim, Manaus

\begin{tabular}{|c|c|c|}
\hline $\begin{array}{c}\text { Comunidade Japiim } \\
\text { Código da amostra }\end{array}$ & $\begin{array}{c}\text { MeHg }\left(\mathrm{mg} \mathrm{kg}^{-1}\right) \\
\text { (média } \pm \text { d.p.) }\end{array}$ & $\begin{array}{c}\text { Incerteza Expandida } \\
\mathbf{U}\left(\mathrm{mg} \mathrm{kg}^{-1}\right)\end{array}$ \\
\hline 158 & $0,9 \pm 0,1$ & $\pm 0,1$ \\
\hline 159 & ND & - \\
\hline 160 & ND & - \\
\hline 161 & ND & - \\
\hline 162 & ND & - \\
\hline 163 & ND & - \\
\hline 164 & $2,2 \pm 0,1$ & $\pm 0,3$ \\
\hline 165 & $0,6 \pm 0,1$ & $\pm 0,1$ \\
\hline 166 & $<\mathrm{LD}$ & - \\
\hline 167 & ND & - \\
\hline 168 & $0,18 \pm 0,02$ & $\pm 0,03$ \\
\hline 169 & $1,2 \pm 0,1$ & $\pm 0,2$ \\
\hline 170 & $2,2 \pm 0,3$ & $\pm 0,3$ \\
\hline 171 & $<\mathrm{LD}$ & - \\
\hline 172 & $<L D$ & - \\
\hline 173 & ND & - \\
\hline 174 & $<\mathrm{LD}$ & - \\
\hline 175 & $0,27 \pm 0,03$ & $\pm 0,04$ \\
\hline 176 & $0,56 \pm 0,03$ & $\pm 0,08$ \\
\hline 177 & $0,91 \pm 0,06$ & $\pm 0,13$ \\
\hline 178 & $0,32 \pm 0,02$ & $\pm 0,05$ \\
\hline 179 & $3,4 \pm 0,3$ & $\pm 0,5$ \\
\hline 180 & $1,03 \pm 0,02$ & $\pm 0,5$ \\
\hline 181 & $1,08 \pm 0,05$ & $\pm 0,15$ \\
\hline 182 & ND & - \\
\hline 183 & $0,63 \pm 0,02$ & $\pm 0,09$ \\
\hline 184 & ND & - \\
\hline 185 & $0,94 \pm 0,05$ & $\pm 0,13$ \\
\hline 186 & $0,74 \pm 0,02$ & $\pm 0,06$ \\
\hline 187 & $0,73 \pm 0,02$ & $\pm 0,06$ \\
\hline 188 & $1,13 \pm 0,04$ & $\pm 0,16$ \\
\hline 189 & $2,2 \pm 0,1$ & $\pm 0,3$ \\
\hline 190 & $1,02 \pm 0,05$ & $\pm 0,15$ \\
\hline 191 & $<\mathrm{LD}$ & - \\
\hline 192 & $<\mathrm{LD}$ & - \\
\hline 193 & $0,57 \pm 0,03$ & $\pm 0,08$ \\
\hline 194 & $5,7 \pm 0,5$ & $\pm 0,8$ \\
\hline 195 & ND & - \\
\hline 196 & ND & - \\
\hline 197 & $<\mathrm{LD}$ & - \\
\hline 198 & ND & - \\
\hline 199 & $<\mathrm{LD}$ & - \\
\hline 200 & $1,5 \pm 0,1$ & $\pm 0,2$ \\
\hline 201 & $1,8 \pm 0,1$ & $\pm 0,2$ \\
\hline 202 & $1,1 \pm 0,1$ & $\pm 0,1$ \\
\hline
\end{tabular}

* <LD - valor menor que o limite de deteção.

* ND - não determinado. 


\section{ANEXO XVIII - Metilmercúrio em cabelos}

Tabela 36 - Teor de MeHg em cabelos, com os desvios padrões (s) e as incertezas expandidas para o bairro São José, Manaus

\begin{tabular}{c|c|c}
\hline $\begin{array}{c}\text { Comunidade São José } \\
\text { Código da amostra }\end{array}$ & $\begin{array}{c}\text { MeHg }\left(\mathbf{m g ~ k g}^{-1}\right) \\
\text { (média } \pm \text { d.p.) }\end{array}$ & $\begin{array}{c}\text { Incerteza Expandida } \\
\mathbf{U}\left(\mathbf{m g ~ k g}^{-1}\right)\end{array}$ \\
\hline 127 & $1,06 \pm 0,04$ & $\pm 0,15$ \\
128 & $<$ LD & - \\
129 & $<$ LD & - \\
130 & $<$ LD & - \\
131 & ND & - \\
132 & ND & - \\
133 & ND & - \\
134 & ND & - \\
135 & $<$ LD & - \\
136 & $<$ LD & - \\
137 & $<$ LD & - \\
138 & $<$ LD & - \\
139 & $<$ LD & - \\
140 & $<$ LD & - \\
141 & $<L D$ & - \\
142 & $<L D$ & - \\
143 & $<L D$ & - \\
144 & ND & - \\
145 & ND & - \\
146 & ND & - \\
147 & $<L D$ & - \\
148 & $<L D$ & - \\
149 & ND & - \\
150 & ND & - \\
151 & $1,01 \pm 0,03$ & $\pm 0,14$ \\
152 & $2,2 \pm 0,1$ & $\pm 0,3$ \\
153 & $1,8 \pm 0,2$ & $\pm 0,2$ \\
154 & $0,54 \pm 0,04$ & $\pm 0,07$ \\
155 & $3,0 \pm 0,1$ & - \\
156 & ND & $\pm 0,2$ \\
157 & $1,1 \pm 0,1$ & \\
\hline
\end{tabular}

* <LD - valor menor que o limite de deteção.

* ND - não determinado. 
ANEXO XIX - Informações obtidas a partir do preenchimento do questionário para as crianças participantes do estudo.

Tabela 37 . Dados antropométricos e informações obtidas a partir do questionário respondido pela mãe ou responsável para cada criança participante do estudo

\begin{tabular}{|c|c|c|c|c|c|c|c|c|}
\hline Código & № & Bairro & Sexo & D.Nasc & Peso & Altura & Classe & Carne (S) (N) \\
\hline 1 & 14 & Alvorada & $\mathrm{F}$ & $4 / 8 / 2001$ & 18,5 & 110,2 & D & $\mathrm{S}$ \\
\hline 2 & 17 & Alvorada & $\mathrm{M}$ & $8 / 2 / 2002$ & 15 & 91 & $\mathrm{C}$ & $\mathrm{S}$ \\
\hline 3 & 18 & Alvorada & $\mathrm{F}$ & 7/7/2002 & 11 & 82 & $E$ & $\mathrm{~S}$ \\
\hline 4 & 19 & Alvorada & $\mathrm{F}$ & 29/9/2003 & 10,7 & 81 & $\mathrm{D}$ & $\mathrm{S}$ \\
\hline 5 & 20 & Alvorada & $\mathrm{F}$ & $9 / 10 / 2000$ & 16,6 & 106 & $\mathrm{D}$ & $\mathrm{S}$ \\
\hline 6 & 1 & Alvorada & $M$ & $17 / 9 / 2001$ & 16 & 102,7 & C & $\mathrm{S}$ \\
\hline 7 & 2 & Alvorada & $\mathrm{F}$ & $14 / 10 / 2000$ & 16,2 & 103 & $\mathrm{D}$ & $\mathrm{S}$ \\
\hline 8 & 3 & Alvorada & $\mathrm{F}$ & $1 / 9 / 2001$ & 13 & 97 & $\mathrm{D}$ & $\mathrm{S}$ \\
\hline 9 & 4 & Alvorada & $\mathrm{F}$ & $17 / 11 / 2003$ & 10,1 & 80 & $\mathrm{D}$ & $\mathrm{S}$ \\
\hline 10 & 5 & Alvorada & $\mathrm{F}$ & $11 / 2 / 2000$ & 15,8 & 107 & C & $\mathrm{S}$ \\
\hline 11 & 6 & Alvorada & $M$ & $8 / 3 / 2001$ & 14 & 95 & C & $\mathrm{S}$ \\
\hline 12 & 7 & Alvorada & $\mathrm{M}$ & $24 / 10 / 2002$ & 12,4 & 92 & $\mathrm{D}$ & $\mathrm{S}$ \\
\hline 13 & 8 & Alvorada & $\mathrm{F}$ & $25 / 2 / 2000$ & 18,8 & 109 & C & $\mathrm{S}$ \\
\hline 14 & 9 & Alvorada & $\mathrm{F}$ & $19 / 11 / 2002$ & 12,7 & 87,5 & C & $\mathrm{S}$ \\
\hline 15 & 10 & Alvorada & $\mathrm{F}$ & $27 / 2 / 2000$ & 14,2 & 100 & $\mathrm{D}$ & $\mathrm{S}$ \\
\hline 16 & 11 & Alvorada & $F$ & $20 / 4 / 2002$ & 14,7 & 96 & $E$ & $S$ \\
\hline 17 & 12 & Alvorada & $M$ & $13 / 12 / 2000$ & 19,1 & 108,3 & $\mathrm{D}$ & $\mathrm{S}$ \\
\hline 18 & 13 & Alvorada & $\mathrm{F}$ & 20/1/2002 & 15,1 & 98 & $\mathrm{D}$ & $\mathrm{S}$ \\
\hline 19 & 15 & Alvorada & $M$ & 19/10/1999 & 15,3 & 100,5 & $\mathrm{D}$ & $\mathrm{S}$ \\
\hline 20 & 16 & Alvorada & $\mathrm{F}$ & 9/10/2002 & 12 & 90,6 & $\mathrm{D}$ & $\mathrm{S}$ \\
\hline 21 & 21 & Alvorada & $F$ & $25 / 4 / 2003$ & 13,3 & 87 & $\mathrm{D}$ & $\mathrm{S}$ \\
\hline 22 & 22 & Alvorada & $\mathrm{M}$ & $25 / 4 / 2002$ & 17 & 98 & $B$ & $\mathrm{~S}$ \\
\hline 1 & 97 & Cidade Nova & $\mathrm{M}$ & $30 / 4 / 2001$ & 16,6 & 101 & C & $\mathrm{S}$ \\
\hline 2 & 98 & Cidade Nova & $\mathrm{M}$ & $25 / 9 / 2002$ & 14,1 & 93,7 & C & $\mathrm{S}$ \\
\hline 3 & 99 & Cidade Nova & M & $10 / 11 / 2003$ & 11,9 & 87 & $\mathrm{D}$ & $\mathrm{S}$ \\
\hline 4 & 100 & Cidade Nova & $\mathrm{F}$ & 6/9/2003 & 12,6 & 92 & $\mathrm{D}$ & $\mathrm{S}$ \\
\hline 5 & 101 & Cidade Nova & $\mathrm{M}$ & $25 / 9 / 2002$ & 14,3 & 94 & C & $\mathrm{S}$ \\
\hline 6 & 102 & Cidade Nova & $M$ & $22 / 3 / 2002$ & 11,1 & 88 & $\mathrm{D}$ & $\mathrm{S}$ \\
\hline 7 & 103 & Cidade Nova & $F$ & 4/4/2002 & 13 & 85,5 & $\mathrm{D}$ & $\mathrm{S}$ \\
\hline
\end{tabular}




\begin{tabular}{|c|c|c|c|c|c|c|c|}
\hline 8 & 104 Cidade Nova & $F$ & 6/9/2003 & 13,1 & 91 & C & $\mathrm{S}$ \\
\hline 9 & 105 Cidade Nova & $\mathrm{M}$ & $12 / 6 / 2000$ & 13,9 & 94 & C & $\mathrm{S}$ \\
\hline 10 & 106 Cidade Nova & $\mathrm{F}$ & $30 / 8 / 2001$ & 14,8 & 105,4 & $E$ & $\mathrm{~S}$ \\
\hline 11 & 107 Cidade Nova & $\mathrm{F}$ & $14 / 12 / 001$ & 14,9 & 103,2 & $\mathrm{D}$ & $\mathrm{N}$ \\
\hline 12 & $\begin{array}{l}108 \text { Cidade Nova } \\
\end{array}$ & $\mathrm{F}$ & $10 / 2 / 2000$ & 18,8 & 110,9 & $\mathrm{C}$ & $\mathrm{S}$ \\
\hline 13 & 109 Cidade Nova & $\mathrm{F}$ & $25 / 5 / 2002$ & 13,5 & 91 & $\mathrm{D}$ & $S$ \\
\hline 14 & 110 Cidade Nova & $F$ & $9 / 11 / 2002$ & 12,6 & 91,6 & $\mathrm{D}$ & $\mathrm{S}$ \\
\hline 15 & 111 Cidade Nova & $\mathrm{M}$ & $28 / 9 / 2002$ & 15,8 & 91,8 & C & $\mathrm{S}$ \\
\hline 16 & 112 Cidade Nova & $\mathrm{F}$ & $21 / 9 / 2000$ & 16,1 & 99 & $\mathrm{D}$ & $\mathrm{S}$ \\
\hline 17 & 113 Cidade Nova & $\mathrm{M}$ & $7 / 8 / 2002$ & 12,8 & 89 & $\mathrm{D}$ & $\mathrm{S}$ \\
\hline 18 & 114 Cidade Nova & $\mathrm{M}$ & $11 / 10 / 2001$ & 15,5 & 102 & $\mathrm{D}$ & $\mathrm{S}$ \\
\hline 19 & 115 Cidade Nova & $\mathrm{M}$ & 8/3/2002 & 15 & 98 & C & $\mathrm{S}$ \\
\hline 20 & \begin{tabular}{l|l|}
116 & Cidade Nova \\
\end{tabular} & $\mathrm{F}$ & $17 / 1 / 2002$ & 14,3 & 98 & $\mathrm{D}$ & $\mathrm{S}$ \\
\hline 21 & 117 Cidade Nova & $\mathrm{F}$ & $23 / 2 / 2001$ & 14,7 & 99 & $\mathrm{D}$ & $\mathrm{N}$ \\
\hline 22 & 118 Cidade Nova & $\mathrm{F}$ & $7 / 7 / 2000$ & 14,8 & 101,2 & $\mathrm{D}$ & $\mathrm{S}$ \\
\hline 23 & 119 Cidade Nova & $F$ & $24 / 3 / 2001$ & 14,9 & 97,6 & $\mathrm{D}$ & $\mathrm{S}$ \\
\hline 24 & $\begin{array}{ll}120 & \text { Cidade Nova } \\
\end{array}$ & $\mathrm{M}$ & $1 / 12 / 2002$ & 16,8 & 14 & $\mathrm{D}$ & $\mathrm{S}$ \\
\hline 25 & 121 Cidade Nova & $\mathrm{M}$ & $2 / 5 / 2003$ & 12,6 & 80 & C & $\mathrm{S}$ \\
\hline 26 & 122 Cidade Nova & $\mathrm{F}$ & $6 / 9 / 2001$ & 18,6 & 1 & $\mathrm{C}$ & $\mathrm{S}$ \\
\hline 27 & \begin{tabular}{l|l}
123 & Cidade Nova \\
\end{tabular} & $F$ & $30 / 7 / 2001$ & 17,2 & 1,01 & $\mathrm{D}$ & $\mathrm{S}$ \\
\hline 28 & 124 Cidade Nova & $\mathrm{M}$ & $7 / 12 / 2002$ & 17,4 & 102,5 & $\mathrm{D}$ & $\mathrm{S}$ \\
\hline 29 & 125 Cidade Nova & $\mathrm{F}$ & $7 / 3 / 2001$ & 14 & 95,3 & $\mathrm{C}$ & $\mathrm{N}$ \\
\hline 30 & \begin{tabular}{ll|l}
126 & Cidade Nova
\end{tabular} & $\mathrm{F}$ & $12 / 5 / 2001$ & 14,9 & 97,6 & $E$ & $\mathrm{~S}$ \\
\hline 31 & 96 Cidade Nova & $\mathrm{F}$ & $19 / 1 / 2002$ & 11,3 & 85,5 & $\mathrm{C}$ & $\mathrm{S}$ \\
\hline 1 & 57 Compensa & $\mathrm{F}$ & $22 / 8 / 2002$ & 15,9 & 91 & $\mathrm{D}$ & $\mathrm{S}$ \\
\hline 2 & 58 Compensa & $\mathrm{F}$ & $24 / 2 / 2000$ & 18,3 & 109 & $\mathrm{D}$ & $\mathrm{S}$ \\
\hline 3 & 59 Compensa & $\mathrm{M}$ & $7 / 9 / 2001$ & 17,3 & 107 & $\mathrm{D}$ & $\mathrm{S}$ \\
\hline 4 & 60 Compensa & $\mathrm{M}$ & $21 / 9 / 2001$ & 14,5 & 98 & $\mathrm{D}$ & $\mathrm{S}$ \\
\hline 5 & 61 Compensa & $\mathrm{M}$ & $21 / 6 / 2002$ & 14 & 90,5 & $\mathrm{D}$ & $\mathrm{S}$ \\
\hline 6 & 62 Compensa & $\mathrm{F}$ & $19 / 4 / 2001$ & 15 & 95 & $\mathrm{D}$ & $\mathrm{S}$ \\
\hline 7 & 63 Compensa & $\mathrm{M}$ & $7 / 8 / 2000$ & 16,2 & 97 & $\mathrm{D}$ & $\mathrm{S}$ \\
\hline 8 & 64 Compensa & $\mathrm{F}$ & $31 / 12 / 2001$ & 12 & 91 & $\mathrm{D}$ & $\mathrm{S}$ \\
\hline 9 & 65 Compensa & $F$ & $16 / 8 / 2000$ & 19,4 & 107,5 & $\mathrm{D}$ & $\mathrm{S}$ \\
\hline 10 & \begin{tabular}{l|l}
66 & Compensa \\
\end{tabular} & $\mathrm{M}$ & 7/1/2003 & 13,2 & 92 & C & $\mathrm{S}$ \\
\hline
\end{tabular}




\begin{tabular}{|c|c|c|c|c|c|c|c|}
\hline 11 & 67 Compensa & $F$ & $14 / 9 / 2002$ & 14,7 & 91 & $\mathrm{D}$ & $\mathrm{S}$ \\
\hline 12 & 68 Compensa & $\mathrm{M}$ & $2 / 1 / 2003$ & 10,5 & 84 & $B$ & $\mathrm{~S}$ \\
\hline 13 & 69 Compensa & $\mathrm{F}$ & $31 / 3 / 2003$ & 10,3 & 111,7 & C & $\mathrm{S}$ \\
\hline 14 & 70 Compensa & $\mathrm{F}$ & 4/2/2003 & 12,9 & 88 & $\mathrm{D}$ & $\mathrm{S}$ \\
\hline 15 & 71 Compensa & $\mathrm{M}$ & $17 / 10 / 2001$ & 20,4 & 92,3 & C & $\mathrm{S}$ \\
\hline 16 & 72 Compensa & $\mathrm{M}$ & 20/12/1999 & 18,7 & 108,4 & $\mathrm{D}$ & $S$ \\
\hline 17 & 73 Compensa & $\mathrm{M}$ & 7/4/2002 & 14,4 & 104,3 & $\mathrm{D}$ & $\mathrm{S}$ \\
\hline 18 & 74 Compensa & $\mathrm{F}$ & $17 / 3 / 2001$ & 15,9 & 98,3 & $\mathrm{D}$ & $\mathrm{S}$ \\
\hline 19 & 75 Compensa & $\mathrm{F}$ & 9/6/1999 & 16,7 & 109,7 & $\mathrm{D}$ & $\mathrm{S}$ \\
\hline 20 & 76 Compensa & $\mathrm{F}$ & $27 / 9 / 2001$ & 12,2 & 105 & C & $\mathrm{S}$ \\
\hline 21 & 77 Compensa & $F$ & 4/11/1999 & 13,9 & 102 & $\mathrm{D}$ & $\mathrm{S}$ \\
\hline 22 & 78 Compensa & $\mathrm{M}$ & $4 / 2 / 2000$ & 16,7 & 111,5 & $\mathrm{C}$ & $\mathrm{S}$ \\
\hline 23 & 79 Compensa & $\mathrm{F}$ & $23 / 9 / 2002$ & 12,3 & 87 & $\mathrm{D}$ & $\mathrm{S}$ \\
\hline 24 & 80 Compensa & $\mathrm{F}$ & $27 / 6 / 2000$ & 18,3 & 105 & C & $\mathrm{S}$ \\
\hline 25 & 81 Compensa & $\mathrm{F}$ & 29/11/2002 & 13,1 & 94 & $\mathrm{D}$ & $\mathrm{N}$ \\
\hline 26 & 82 Compensa & $\mathrm{M}$ & 29/1/2001 & 13,4 & 93 & $\mathrm{D}$ & $\mathrm{N}$ \\
\hline 27 & 83 Compensa & $\mathrm{M}$ & 1/1/1999 & 16,1 & 105 & C & $\mathrm{S}$ \\
\hline 28 & 84 Compensa & $\mathrm{M}$ & $12 / 2 / 1999$ & 16,4 & 106,5 & $\mathrm{D}$ & $\mathrm{S}$ \\
\hline 29 & 85 Compensa & $\mathrm{F}$ & 2/11/1999 & 15,8 & 106 & C & $\mathrm{S}$ \\
\hline 30 & 86 Compensa & $\mathrm{F}$ & $11 / 11 / 2002$ & 13,1 & 86,4 & $\mathrm{D}$ & $\mathrm{S}$ \\
\hline 31 & 88 Compensa & $F$ & $18 / 7 / 2000$ & 15 & 105,3 & $\mathrm{D}$ & $\mathrm{S}$ \\
\hline 32 & 89 Compensa & $\mathrm{M}$ & $26 / 10 / 2001$ & 14,3 & 95 & $\mathrm{C}$ & $\mathrm{S}$ \\
\hline 33 & 90 Compensa & $\mathrm{F}$ & 19/9/1999 & 16,8 & 112,5 & D & $\mathrm{S}$ \\
\hline 34 & 91 Compensa & $\mathrm{F}$ & $18 / 3 / 2001$ & 14,2 & 99,4 & $\mathrm{D}$ & $\mathrm{S}$ \\
\hline 35 & 92 Compensa & $\mathrm{F}$ & $13 / 9 / 2001$ & 14,2 & 89,6 & $\mathrm{D}$ & $\mathrm{S}$ \\
\hline 36 & 93 Compensa & $\mathrm{F}$ & $22 / 3 / 2001$ & 12,7 & 90 & $\mathrm{~B}$ & $\mathrm{~S}$ \\
\hline 37 & 94 Compensa & $\mathrm{F}$ & $27 / 5 / 2002$ & 13,5 & 95,7 & C & $\mathrm{N}$ \\
\hline 38 & 95 Compensa & $F$ & $22 / 11 / 2002$ & 13,3 & 99,3 & $\mathrm{C}$ & $\mathrm{N}$ \\
\hline 39 & 56 Compensa & $F$ & $31 / 3 / 2001$ & 14,7 & 97 & $\mathrm{D}$ & $\mathrm{S}$ \\
\hline 40 & 87 Compensa & $\mathrm{F}$ & $16 / 9 / 2000$ & 15,3 & 107,5 & C & $\mathrm{S}$ \\
\hline 1 & 24 Flores & $\mathrm{M}$ & $1 / 1 / 2000$ & 15,6 & 104 & $\mathrm{D}$ & $\mathrm{S}$ \\
\hline 2 & 25 Flores & $\mathrm{M}$ & $13 / 2 / 2000$ & 20,4 & 103,5 & $D$ & $\mathrm{~S}$ \\
\hline 3 & \begin{tabular}{l|l|l}
26 & Flores \\
\end{tabular} & $F$ & $29 / 6 / 2000$ & 17,4 & 103 & C & $\mathrm{S}$ \\
\hline 4 & 27 Flores & $\mathrm{M}$ & $28 / 3 / 2003$ & 13,9 & 87,3 & $D$ & $\mathrm{~S}$ \\
\hline
\end{tabular}




\begin{tabular}{|c|c|c|c|c|c|c|c|}
\hline 5 & \begin{tabular}{l|l|}
28 & Flores \\
\end{tabular} & $F$ & $11 / 5 / 2000$ & 16,6 & 101 & $\mathrm{D}$ & $\mathrm{S}$ \\
\hline 6 & 29 Flores & M & $20 / 11 / 2001$ & 17,4 & 101 & $\mathrm{~B}$ & $\mathrm{~S}$ \\
\hline 7 & 30 Flores & $\mathrm{F}$ & 6/1/2001 & 15,3 & 104 & $\mathrm{D}$ & $\mathrm{S}$ \\
\hline 8 & 31 Flores & M & $9 / 11 / 2001$ & 12,1 & 84,9 & $\mathrm{D}$ & $\mathrm{S}$ \\
\hline 9 & 32 Flores & $\mathrm{F}$ & $5 / 3 / 2003$ & 16 & 91,9 & $\mathrm{~B}$ & $\mathrm{~S}$ \\
\hline 10 & 33 $\mid$ Flores & $M$ & 15/10/1999 & 18 & 106 & C & $S$ \\
\hline 11 & 34 Flores & $M$ & $1 / 1 / 2000$ & 23,2 & 11,3 & $\mathrm{~B}$ & $\mathrm{~S}$ \\
\hline 12 & 35 Flores & $\mathrm{F}$ & $22 / 4 / 2003$ & 9,3 & 77,3 & C & $\mathrm{S}$ \\
\hline 13 & \begin{tabular}{l|l}
36 & Flores \\
\end{tabular} & $\mathrm{F}$ & $21 / 3 / 2002$ & 14,3 & 91,6 & $\mathrm{D}$ & $\mathrm{S}$ \\
\hline 14 & 37 Flores & $\mathrm{F}$ & $21 / 6 / 2001$ & 14,4 & 100 & $\mathrm{D}$ & $\mathrm{S}$ \\
\hline 15 & \begin{tabular}{l|l|}
38 & Flores \\
\end{tabular} & M & 2/5/2000 & 13,8 & 93,6 & $\mathrm{D}$ & $\mathrm{N}$ \\
\hline 16 & 39 Flores & $M$ & 29/12/2002 & 12,7 & 87,5 & $\mathrm{C}$ & $\mathrm{N}$ \\
\hline 17 & 40 Flores & M & $19 / 3 / 2001$ & 13,8 & 91,8 & C & $\mathrm{S}$ \\
\hline 18 & \begin{tabular}{l|l}
41 & Flores \\
\end{tabular} & $M$ & $27 / 4 / 2002$ & 14,1 & 94,5 & $\mathrm{D}$ & $\mathrm{S}$ \\
\hline 19 & \begin{tabular}{l|l}
42 & Flores \\
\end{tabular} & $\mathrm{F}$ & $1 / 10 / 1999$ & 20,5 & 111,2 & $\mathrm{C}$ & $\mathrm{S}$ \\
\hline 20 & \begin{tabular}{l|l}
43 & Flores
\end{tabular} & $\mathrm{F}$ & $20 / 12 / 2005$ & 11,4 & 86,2 & C & $\mathrm{S}$ \\
\hline 21 & \begin{tabular}{l|l|}
44 & Flores \\
\end{tabular} & M & $11 / 9 / 2001$ & 15,3 & 96,1 & $\mathrm{D}$ & $\mathrm{S}$ \\
\hline 22 & 45 Flores & $F$ & $22 / 10 / 2002$ & 12,5 & 85 & C & $\mathrm{S}$ \\
\hline 23 & \begin{tabular}{l|l|}
46 & Flores \\
\end{tabular} & $\mathrm{F}$ & $29 / 2 / 2000$ & 15,9 & 101,2 & $\mathrm{D}$ & $\mathrm{S}$ \\
\hline 24 & 47 Flores & $\mathrm{F}$ & $20 / 7 / 2001$ & 14,9 & 97,2 & C & $\mathrm{S}$ \\
\hline 25 & \begin{tabular}{l|l|}
48 & Flores \\
\end{tabular} & $\mathrm{F}$ & $25 / 9 / 2000$ & 16,3 & 110,5 & $\mathrm{C}$ & $\mathrm{S}$ \\
\hline 26 & \begin{tabular}{l|l}
49 & Flores \\
\end{tabular} & $\mathrm{F}$ & $3 / 12 / 2002$ & 12,8 & 84,5 & $\mathrm{D}$ & $\mathrm{S}$ \\
\hline 27 & 50 Flores & $\mathrm{F}$ & 12/11/1999 & 17,6 & 10,6 & $\mathrm{C}$ & $S$ \\
\hline 28 & \begin{tabular}{l|l|}
51 & Flores \\
\end{tabular} & $\mathrm{F}$ & $28 / 8 / 2002$ & 13,5 & 93,4 & $\mathrm{D}$ & $\mathrm{S}$ \\
\hline 29 & 52 Flores & M & $23 / 9 / 2000$ & 17,6 & 103,4 & $\mathrm{D}$ & $\mathrm{S}$ \\
\hline 30 & 53 Flores & $\mathrm{F}$ & 28/9/1991 & 50 & 1,52 & $\mathrm{~B}$ & $\mathrm{~S}$ \\
\hline 31 & 54 Flores & $\mathrm{F}$ & $31 / 1 / 2003$ & 12,8 & 85 & $\mathrm{D}$ & $\mathrm{S}$ \\
\hline 32 & 55 Flores & $\mathrm{F}$ & $17 / 2 / 2002$ & 14,8 & 89,5 & $\mathrm{C}$ & $\mathrm{S}$ \\
\hline 33 & 23 Flores & M & $31 / 10 / 2001$ & 13,3 & 91 & $\mathrm{D}$ & $\mathrm{S}$ \\
\hline 1 & 158 Japiim & $\mathrm{F}$ & $20 / 12 / 2001$ & 15 & 89,4 & $\mathrm{D}$ & $\mathrm{S}$ \\
\hline 2 & 159 Japiim & $F$ & 29/4/2002 & 13,9 & 92 & C & $\mathrm{S}$ \\
\hline 3 & $\begin{array}{l}160 \\
\end{array}$ & $F$ & 7/9/2003 & 11,5 & 83 & $D$ & $\mathrm{~S}$ \\
\hline 4 & 161 Japiim & $F$ & $9 / 3 / 2002$ & 15,1 & 92 & C & $\mathrm{S}$ \\
\hline 5 & \begin{tabular}{l|l|}
162 & Japiim \\
\end{tabular} & $M$ & 23/5/1999 & 20 & 106 & $\mathrm{C}$ & $\mathrm{S}$ \\
\hline
\end{tabular}




\begin{tabular}{|c|c|c|c|c|c|c|c|}
\hline 6 & \begin{tabular}{l|l|}
163 & Japiim \\
\end{tabular} & $\mathrm{F}$ & $10 / 5 / 2000$ & 16 & 106,5 & $\mathrm{D}$ & $\mathrm{S}$ \\
\hline 7 & 164 Japiim & $M$ & $23 / 5 / 2000$ & 22,6 & 115 & $\mathrm{D}$ & $\mathrm{S}$ \\
\hline 8 & 165 Japiim & $\mathrm{F}$ & $24 / 2 / 2001$ & 15 & 93 & C & $\mathrm{S}$ \\
\hline 9 & 166 Japiim & $\mathrm{F}$ & $15 / 6 / 2000$ & 14,8 & 1,03 & $\mathrm{D}$ & $\mathrm{S}$ \\
\hline 10 & 167 Japiim & $M$ & $11 / 7 / 2002$ & 12,7 & 89 & $\mathrm{D}$ & $\mathrm{S}$ \\
\hline 11 & 168 Japiim & $\mathrm{F}$ & $4 / 6 / 2001$ & 14,9 & 96 & $\mathrm{D}$ & $S$ \\
\hline 12 & 169 Japiim & $\mathrm{F}$ & $11 / 11 / 2000$ & 14 & 96 & $\mathrm{D}$ & $\mathrm{S}$ \\
\hline 13 & 170 Japiim & $\mathrm{F}$ & 23/2/2002 & 14,2 & 98,5 & C & $\mathrm{S}$ \\
\hline 14 & 171 Japiim & $M$ & $7 / 11 / 2001$ & 20,4 & 99,8 & $\mathrm{D}$ & $\mathrm{S}$ \\
\hline 15 & 172 Japiim & $M$ & $14 / 8 / 2002$ & 16,4 & 101,5 & $\mathrm{D}$ & $\mathrm{S}$ \\
\hline 16 & \begin{tabular}{l|l|}
173 & Japiim \\
\end{tabular} & $\mathrm{M}$ & $11 / 4 / 2002$ & 10,5 & 87 & $E$ & $\mathrm{~S}$ \\
\hline 17 & 174 Japiim & $\mathrm{F}$ & $24 / 1 / 2000$ & 13,6 & 10 & $E$ & $\mathrm{~S}$ \\
\hline 18 & 175 Japiim & $\mathrm{M}$ & $7 / 7 / 2002$ & 15,5 & 103,3 & $\mathrm{D}$ & $\mathrm{S}$ \\
\hline 19 & 176 Japiim & $\mathrm{F}$ & $7 / 1 / 2001$ & 16,6 & 105 & C & $\mathrm{S}$ \\
\hline 20 & $\begin{array}{ll}177 & \text { Japiim } \\
\end{array}$ & $\mathrm{F}$ & 29/12/2001 & 11,5 & 85 & $\mathrm{D}$ & $\mathrm{N}$ \\
\hline 21 & 178 Japiim & $M$ & $1 / 12 / 2000$ & 13,6 & 105 & C & $\mathrm{S}$ \\
\hline 22 & 179 Japiim & $\mathrm{F}$ & $25 / 2 / 2000$ & 15,5 & 99 & $E$ & $\mathrm{~S}$ \\
\hline 23 & 180 Japiim & $\mathrm{F}$ & $17 / 4 / 2000$ & 16,3 & 104 & $\mathrm{D}$ & $\mathrm{S}$ \\
\hline 24 & 181 Japiim & M & 18/3/1999 & 22,5 & 118,5 & $\mathrm{C}$ & $\mathrm{S}$ \\
\hline 25 & 182 Japiim & $\mathrm{F}$ & $1 / 3 / 2002$ & 12,4 & 95,2 & $\mathrm{D}$ & $\mathrm{S}$ \\
\hline 26 & 183 Japiim & $\mathrm{F}$ & 10/10/1999 & 15 & 101,5 & $E$ & $\mathrm{~S}$ \\
\hline 27 & 184 Japiim & $\mathrm{F}$ & 7/8/2003 & 12,5 & 85 & $B$ & $\mathrm{~S}$ \\
\hline 28 & 185 Japiim & $\mathrm{F}$ & 9/6/2003 & 11,5 & 85 & $E$ & $S$ \\
\hline 29 & \begin{tabular}{l|l|}
186 & Japiim \\
\end{tabular} & M & $15 / 10 / 2003$ & 11,6 & 88 & $E$ & $\mathrm{~S}$ \\
\hline 30 & 187 Japiim & $\mathrm{F}$ & 6/9/2002 & 15 & 96 & B & $\mathrm{S}$ \\
\hline 31 & 189 Japiim & $\mathrm{F}$ & 14/1/2002 & 13 & 78 & $\mathrm{D}$ & $\mathrm{S}$ \\
\hline 32 & 190 Japiim & $M$ & $22 / 1 / 2000$ & 18 & 103 & $\mathrm{D}$ & $\mathrm{S}$ \\
\hline 33 & 191 Japiim & M & 19/6/2002 & 12 & 88,3 & $\mathrm{D}$ & $\mathrm{S}$ \\
\hline 34 & 192 Japiim & M & $13 / 3 / 2001$ & 12,3 & 87 & $\mathrm{D}$ & $\mathrm{S}$ \\
\hline 35 & \begin{tabular}{l|l}
193 & Japiim \\
\end{tabular} & $\mathrm{F}$ & $26 / 12 / 2000$ & 13 & 96,6 & $E$ & $\mathrm{~N}$ \\
\hline 36 & 194 Japiim & M & $1 / 11 / 2000$ & 18,7 & 107 & $\mathrm{D}$ & $\mathrm{S}$ \\
\hline 37 & 195 Japiim & $\mathrm{F}$ & $3 / 5 / 2000$ & 17 & 110 & $E$ & $\mathrm{~S}$ \\
\hline 38 & 196 Japiim & $\mathrm{F}$ & $4 / 9 / 2001$ & 16 & 104 & $\mathrm{D}$ & $\mathrm{S}$ \\
\hline 39 & 197 Japiim & $F$ & $5 / 7 / 2002$ & 14 & 107 & C & $\mathrm{S}$ \\
\hline
\end{tabular}




\begin{tabular}{|c|c|c|c|c|c|c|c|}
\hline 40 & 198 Japiim & $F$ & $21 / 12 / 2000$ & 16 & 102,3 & $\mathrm{D}$ & $\mathrm{S}$ \\
\hline 41 & 199 Japiim & $\mathrm{M}$ & $21 / 1 / 2000$ & 17,7 & 111 & $E$ & $\mathrm{~S}$ \\
\hline 42 & 200 Japiim & $\mathrm{F}$ & $15 / 11 / 2002$ & 12 & 85 & $\mathrm{D}$ & $\mathrm{S}$ \\
\hline 43 & 201 Japiim & $\mathrm{M}$ & $15 / 5 / 2001$ & 14,8 & 100 & D & $\mathrm{S}$ \\
\hline 44 & 202 Japiim & $\mathrm{M}$ & 11/7/1999 & 17,7 & 107,8 & $\mathrm{D}$ & $\mathrm{S}$ \\
\hline 45 & 188 Japiim & $\mathrm{M}$ & $31 / 1 / 2002$ & 14,2 & 93 & $\mathrm{D}$ & $S$ \\
\hline 1 & 127 São José & $\mathrm{F}$ & 9/1/2002 & 12,8 & 95 & $\mathrm{D}$ & $\mathrm{S}$ \\
\hline 2 & 129 São José & $F$ & $17 / 4 / 2003$ & 16,8 & 103 & C & $\mathrm{S}$ \\
\hline 3 & 130 São José & $\mathrm{M}$ & 9/3/2002 & 15,5 & 92 & C & $\mathrm{S}$ \\
\hline 4 & 131 São José & $\mathrm{F}$ & $15 / 7 / 2001$ & 14,7 & 95,8 & $\mathrm{D}$ & $\mathrm{S}$ \\
\hline 5 & 132 São José & $\mathrm{F}$ & $6 / 7 / 2001$ & 15,7 & 99 & $\mathrm{D}$ & $\mathrm{S}$ \\
\hline 6 & 133 São José & $\mathrm{M}$ & $10 / 11 / 2001$ & 13 & 93,5 & C & $\mathrm{S}$ \\
\hline 7 & 134 São José & $\mathrm{F}$ & $31 / 10 / 2000$ & 21 & 110 & $\mathrm{D}$ & $\mathrm{S}$ \\
\hline 8 & 135 São José & $\mathrm{M}$ & 1/2/2003 & 14 & 100 & C & $\mathrm{S}$ \\
\hline 9 & 136 São José & $\mathrm{F}$ & 1/9/1999 & 19,2 & 113 & $B$ & $\mathrm{~S}$ \\
\hline 10 & 137 São José & $\mathrm{F}$ & 29/5/1999 & 18 & 110 & $\mathrm{D}$ & $\mathrm{S}$ \\
\hline 11 & 138 São José & $\mathrm{M}$ & $16 / 4 / 2002$ & 14,5 & 96,7 & $\mathrm{D}$ & $\mathrm{N}$ \\
\hline 12 & 139 São José & $\mathrm{M}$ & $3 / 10 / 2000$ & 16 & 101 & $\mathrm{D}$ & $\mathrm{S}$ \\
\hline 13 & 145 São José & $\mathrm{M}$ & $1 / 1 / 2003$ & 12,8 & 87,5 & $\mathrm{D}$ & $\mathrm{S}$ \\
\hline 14 & 146 São José & $\mathrm{M}$ & $17 / 11 / 2002$ & 10,4 & 83,4 & C & $\mathrm{S}$ \\
\hline 15 & 148 São José & $F$ & 14/9/1999 & 14,6 & 101 & $\mathrm{D}$ & $\mathrm{S}$ \\
\hline 16 & 149 São José & $\mathrm{M}$ & $7 / 6 / 2001$ & 14,5 & 98 & $\mathrm{C}$ & $\mathrm{S}$ \\
\hline 17 & 150 São José & $\mathrm{M}$ & $31 / 3 / 2001$ & 20,7 & 104,5 & D & $\mathrm{S}$ \\
\hline 18 & 157 São José & $M$ & $24 / 9 / 2001$ & 15 & 92 & D & S \\
\hline 19 & 147 São José & $M$ & $6 / 11 / 2002$ & 14,5 & 89,6 & D & $S$ \\
\hline 20 & 128 São José & $\mathrm{F}$ & $17 / 3 / 2001$ & 12 & 95 & $\mathrm{D}$ & $\mathrm{S}$ \\
\hline 21 & 140 São José & $\mathrm{F}$ & $27 / 4 / 2001$ & 13 & 92 & C & $\mathrm{N}$ \\
\hline 22 & 141 São José & $F$ & $21 / 12 / 2001$ & 14,5 & 95 & $\mathrm{D}$ & $\mathrm{S}$ \\
\hline 23 & 142 São José & $\mathrm{M}$ & $27 / 1 / 2001$ & 16 & 96 & $\mathrm{C}$ & $\mathrm{S}$ \\
\hline 24 & 143 São José & $\mathrm{M}$ & $21 / 2 / 2000$ & 17 & 111 & $\mathrm{D}$ & $\mathrm{N}$ \\
\hline 25 & 151 São José & $\mathrm{F}$ & 22/11/1999 & 17,2 & 105 & $\mathrm{D}$ & $\mathrm{S}$ \\
\hline 26 & 152 São José & $\mathrm{F}$ & $5 / 4 / 2001$ & 12,7 & 97 & $\mathrm{D}$ & $\mathrm{S}$ \\
\hline 27 & 153 São José & $\mathrm{F}$ & $7 / 10 / 2002$ & 11 & 99,5 & $\mathrm{D}$ & $\mathrm{S}$ \\
\hline 28 & 154 São José & $F$ & $15 / 6 / 2001$ & 16,7 & 100,3 & C & $\mathrm{S}$ \\
\hline
\end{tabular}




\begin{tabular}{|r|l|l|c|c|c|c|c|}
\hline 29 & 155 São José & $M$ & $12 / 5 / 1999$ & 17,5 & 109,5 & $\mathrm{D}$ & $\mathrm{S}$ \\
\hline 30 & 156 São José & $\mathrm{F}$ & $10 / 12 / 2002$ & 13,2 & 85 & $\mathrm{C}$ & $\mathrm{S}$ \\
\hline 31 & 144 São José & $\mathrm{M}$ & $25 / 10 / 1999$ & 25,7 & 118 & $\mathrm{C}$ & $\mathrm{S}$ \\
\hline
\end{tabular}




\section{ANEXO XX - Mercúrio e micronutrientes em peixes, Manaus}

Tabela 43 . Resultados obtidos na análise dos peixes preparados sob diferentes formas de cocção para os elementos $\mathrm{Ca}, \mathrm{Fe}, \mathrm{K}, \mathrm{Na}, \mathrm{Se} e$ $\mathrm{Zn} \mathrm{e} \mathrm{Hg}\left(\mathrm{mg} \mathrm{kg}^{-1}\right)$ e $\mathrm{Hg}$ e Se $\left(\mu \mathrm{kg}^{-1}\right)$

\begin{tabular}{|c|c|c|c|c|c|c|c|c|c|c|c|c|c|c|}
\hline & \multicolumn{2}{|c|}{$\left(\mu \mathrm{g} \mathrm{kg}^{-1}\right)$} & \multicolumn{2}{|c|}{$\left(\mathrm{mg} \mathrm{kg}^{-1}\right)$} & \multicolumn{2}{|c|}{$\left(\mathrm{mg} \mathrm{kg}^{-1}\right)$} & \multicolumn{2}{|c|}{$\left(\mathrm{mg} \mathrm{kg}^{-1}\right)$} & \multicolumn{2}{|c|}{$\left(\mathrm{mg} \mathrm{kg}^{-1}\right)$} & \multicolumn{2}{|c|}{$\left(\mu \mathrm{kg}^{-1}\right)$} & \multicolumn{2}{|c|}{$\left(\mathrm{mg} \mathrm{kg}^{-1}\right)$} \\
\hline & $\mathrm{Hg}$ & d.p. & $\mathrm{K}$ & d.p. & $\mathrm{Ca}$ & d.p. & $\mathrm{Na}$ & d.p. & $\mathrm{Fe}$ & d.p. & $\mathrm{Se}$ & d.p. & $\mathrm{Zn}$ & d.p. \\
\hline 1 - filé de pacu in natura com pele & 92 & 2 & 9599 & 1179 & - & - & 10002 & 1371 & 150 & 4 & 607 & 6 & 139 & 3 \\
\hline 2 - filé de pacu in natura sem pele & 71 & 10 & 12580 & 447 & - & - & 4625 & 411 & 153 & 2 & 990 & 11 & 167 & 11 \\
\hline 46 - pacu in natura com pele & 65 & 2 & 10803 & 713 & 1054 & 35 & 4833 & 233 & 1494 & 175 & 752 & 32 & 47 & 1 \\
\hline 47 - pacu in natura sem pele & 44 & 1 & 11799 & 59 & 1230 & 37 & 5540 & 335 & 1100 & 69 & 569 & 42 & 37 & 1 \\
\hline $11-$ pacu frito & 37 & 6 & 1232 & 32 & 6354 & 369 & 9726 & 138 & 35 & 3 & 129 & 6 & 16 & 1 \\
\hline 12 - pacu tostado & 23 & 8 & 2342 & 59 & 6378 & 145 & 7642 & 483 & 28 & 1 & 322 & 43 & 27 & 4 \\
\hline 3 - pacu cozido & 43 & 3 & 11899 & 1009 & - & - & 15678 & 567 & 116 & 9 & 615 & 99 & 144 & 11 \\
\hline 4 - pacu assado & 56 & 4 & 6215 & 330 & - & - & 12191 & 732 & 284 & 4 & 701 & 81 & 179 & 3 \\
\hline 5 - sardinha in natura com pele (filé) & 376 & 28 & - & - & 3214 & 223 & 6237 & 813 & 696 & 36 & 820 & 6 & 142 & 28 \\
\hline 6 - sardinha in natura sem pele (filé) & 261 & 20 & - & - & 2793 & 259 & 7446 & 135 & 68 & 6 & 991 & 94 & 430 & 131 \\
\hline 48 - sardinha in natura com pele & 192 & 5 & 13711 & 237 & 4107 & 59 & 7632 & 847 & 118 & 1 & 1748 & 168 & 46 & 4 \\
\hline 49 - sardinha in natura sem pele & 275 & 30 & 14240 & 746 & 5044 & 228 & 10874 & 988 & 131 & 7 & 1272 & 127 & 44 & 1 \\
\hline 7 - sardinha frita & 253 & 32 & 4743 & 517 & 3604 & 628 & 11056 & 912 & 141 & 6 & 497 & 60 & 684 & 50 \\
\hline 8 - sardinha tostada & 114 & 9 & 1919 & 102 & 7280 & 724 & 9508 & 572 & 155 & 10 & 747 & 106 & 239 & 54 \\
\hline 50 - sardinha cozida & 293 & 6 & 10258 & 822 & 3718 & 197 & 7777 & 252 & 173 & 5 & 1162 & 74 & 35 & 3 \\
\hline 13 - aracu in natura com pele (filé) & 95 & 23 & 9471 & 460 & 2780 & 241 & 5298 & 273 & 29,2 & 0,2 & 909 & 111 & 28 & 4 \\
\hline 14 - aracu in natura sem pele (filé) & 410 & 45 & 13845 & 760 & 3445 & 394 & 5301 & 266 & 28,5 & 0,4 & 1008 & 203 & 21 & 3 \\
\hline 9 - aracu cozido & 270 & 13 & - & - & 7513 & 724 & 10161 & 1484 & 74 & 5 & 1371 & 52 & 15 & 1 \\
\hline 10 - aracu assado & 120 & 11 & - & - & 7482 & 803 & 11308 & 1178 & 223 & 12 & 990 & 41 & 24 & 5 \\
\hline 15 - aracu frito & 29 & 4 & 7246 & 537 & 1616 & 74 & 15099 & 975 & 1090 & 126 & 314 & 47 & 17 & 1 \\
\hline 16 - pescada in natura com pele & 964 & 211 & 12704 & 814 & 2262 & 208 & 2060 & 113 & 11 & 1 & 1339 & 129 & 22 & 1 \\
\hline 17 - pescada in natura sem pele & 1328 & 283 & 12301 & 1265 & 2615 & 516 & 1588 & 23 & 27 & 1 & 1804 & 26 & 24 & 2 \\
\hline 18 - pescada assada & 1401 & 385 & 5996 & 398 & 1108 & 134 & 5897 & 207 & 4,0 & 0,3 & 1417 & 184 & 15 & 2 \\
\hline 19 - pescada cozida & 1320 & 141 & 10003 & 359 & - & - & 7086 & 128 & 21 & 1 & 1688 & 63 & 23 & 1 \\
\hline 20 - pescada frita & 1163 & 64 & 10076 & 732 & - & - & 10602 & 329 & 20 & 1 & 2639 & 57 & 32 & 1 \\
\hline 21 - tucunaré in natura com pele (filé) & 767 & 155 & 2380 & 162 & 4321 & 58 & 2774 & 141 & 10 & 1 & 4555 & 325 & 35 & 4 \\
\hline 22 - tucunaré in natura sem pele (filé) & 1302 & 122 & 3123 & 89 & 5467 & 213 & 2980 & 45 & 7,1 & 0,2 & 4106 & 177 & 25 & 3 \\
\hline 23 - tucunaré assado & 1063 & 30 & 1185 & 89 & 1328 & 72 & 1294 & 41 & 16 & 1 & 5249 & 789 & 45 & 1 \\
\hline 24 - tucunaré cozido & 1187 & 8 & 1968 & 45 & 1889 & 236 & 5913 & 212 & 13 & 1 & 4248 & 891 & 15 & 1 \\
\hline 25 - tucunaré frito & 1102 & 42 & 1314 & 53 & 994 & 9 & 9227 & 825 & 15,5 & 0,4 & 3649 & 347 & 15,2 & 0,1 \\
\hline 26 - jaraqui in natura com pele & 872 & 6 & 11872 & 1291 & 4942 & 33 & 1679 & 59 & 37 & 3 & 942 & 34 & 38 & 4 \\
\hline 27 - jaraqui in natura sem pele & 995 & 7 & 16955 & 718 & 5166 & 303 & 2608 & 59 & 35 & 1 & 982 & 62 & 26 & 2 \\
\hline
\end{tabular}




\begin{tabular}{|c|c|c|c|c|c|c|c|c|c|c|c|c|c|c|}
\hline 28 - jaraqui assado & 963 & 9 & 15028 & 1199 & 2694 & 269 & 2584 & 211 & 77 & 1 & 928 & 64 & 20 & 1 \\
\hline 29 - jaraqui cozido & 680 & 3 & 15579 & 155 & 1839 & 187 & 4939 & 385 & 79 & 4 & 539 & 64 & 42 & 1 \\
\hline 30 - jaraqui frito & 445 & 3 & 14759 & 138 & 9463 & 39 & 1250 & 152 & 40 & 2 & 575 & 45 & 27 & 1 \\
\hline 31 - curimatã in natura com pele & 60 & 1 & 15308 & 604 & 6348 & 665 & 1901 & 136 & 61 & 3 & 1278 & 134 & 37 & 2 \\
\hline 32 - curimatã in natura sem pele & 74 & 1 & 17334 & 800 & 6326 & 435 & 1267 & 36 & 46 & 1 & 1066 & 70 & 51 & 4 \\
\hline 33 - curimatã assado & 73 & 1 & 8556 & 254 & 9094 & 391 & 1716 & 216 & 37 & 2 & 1310 & 110 & 34 & 2 \\
\hline 34 - curimatã cozido & 35 & 4 & 12966 & 45 & 1828 & 146 & 6724 & 31 & 52 & 4 & 756 & 53 & 28 & 2 \\
\hline 35 - curimatã frito & 38 & 1 & 12850 & 129 & 1814 & 13 & 3557 & 113 & 84 & 1 & 845 & 45 & 32 & 2 \\
\hline 36 - pirapitinga in natura com pele & 27 & 1 & 18552 & 423 & 4614 & 520 & 1989 & 51 & 36 & 1 & 431 & 52 & 30 & 2 \\
\hline 37 - pirapitinga in natura sem pele & 30 & 1 & 12927 & 125 & 5890 & 207 & 2073 & 64 & 23 & 4 & 445 & 26 & 29 & 3 \\
\hline 38 - pirapitinga assado & 46 & 1 & 15023 & 621 & 3423 & 124 & 2846 & 72 & 33 & 2 & 370 & 68 & 70 & 8 \\
\hline 39 - pirapitinga cozido & 19 & 1 & 7226 & 585 & 4334 & 221 & 2725 & 131 & 18 & 1 & 487 & 88 & 56 & 4 \\
\hline 40 - pirapitinga frito & 23 & 1 & 10600 & 74 & 3361 & 206 & 2659 & 87 & 36 & 4 & 372 & 30 & 27 & 1 \\
\hline 41 - surubim in natura com pele & 893 & 45 & 14377 & 697 & 1227 & 94 & 3501 & 78 & 24 & 1 & 878 & 60 & 32 & 2 \\
\hline 42 - surubim in natura sem pele & 937 & 12 & 19187 & 400 & 1800 & 22 & 3796 & 96 & 24 & 3 & 987 & 17 & 27 & 1 \\
\hline 43 - surubim assado & 1138 & 130 & 10135 & 341 & 1001 & 34 & 3647 & 107 & 27 & 2 & 815 & 89 & 27 & 1 \\
\hline 44 - surubim cozido & 755 & 71 & 9309 & 192 & 1025 & 36 & 3241 & 36 & 19 & 1 & 976 & 87 & 35 & 1 \\
\hline 45 - surubim frito & 1604 & 283 & 7370 & 742 & 1230 & 37 & 3540 & 335 & 14 & 1 & 1072 & 15 & 44 & 1 \\
\hline 51 - aruanã in natura com pele & 1508 & 70 & 14259 & 469 & 7237 & 169 & 8059 & 151 & 2877 & 120 & 525 & 88 & 33 & 1 \\
\hline 52 - aruanã in natura sem pele & 2392 & 352 & 14590 & 324 & 14590 & 324 & 8766 & 172 & 2052 & 17 & 635 & 80 & 35 & 2 \\
\hline 53 - aruanã assado & 1674 & 209 & 7676 & 250 & 6799 & 121 & 5700 & 49 & 3320 & 175 & 497 & 9 & 25 & 1 \\
\hline 54 - aruanã cozido & 588 & 30 & 6877 & 145 & 6877 & 145 & 3546 & 123 & 2659 & 1 & 614 & 60 & 20 & 60 \\
\hline 55 - branquinha in natura com pele & 131 & 13 & 6935 & 219 & 3932 & 50 & 18386 & 631 & 1273 & 5 & 490 & 33 & 42,0 & 0,4 \\
\hline 56 - branquinha in natura sem pele & 194 & 22 & 6818 & 165 & 1493 & 79 & 13351 & 510 & 1176 & 76 & 410 & 21 & 30,5 & 0,5 \\
\hline 57 - branquinha assado & 117 & 6 & 7393 & 518 & 1373 & 107 & 12837 & 684 & 1088 & 13 & 388 & 56 & 37,5 & 0,3 \\
\hline 58 - branquinha cozido & 161 & 11 & 5579 & 226 & 1452 & 124 & 11498 & 359 & 1190 & 66 & 410 & 21 & 23 & 2 \\
\hline 59 - branquinha frito & 133 & 9 & 3466 & 33 & 1404 & 98 & 10608 & 328 & 1186 & 71 & 388 & 56 & 24 & 2 \\
\hline 60 - tambaqui in natura com pele & 149 & 21 & 10880 & 23 & 2530 & 163 & 3358 & 205 & 5180 & 69 & 453 & 20 & 23,9 & 0,3 \\
\hline 61 - tambaqui in natura sem pele & 151 & 9 & 12496 & 511 & 2447 & 197 & 3353 & 204 & 5340 & 151 & 446 & 54 & 15 & 1 \\
\hline 62 - tambaqui assado & 642 & 49 & 9777 & 63 & 2103 & 43 & 3041 & 52 & 5580 & 177 & 444 & 13 & 23 & 1 \\
\hline 63 - tambaqui cozido & 129 & 15 & 8720 & 263 & 2070 & 57 & 3794 & 94 & 5136 & 28 & 417 & 39 & 26 & 1 \\
\hline 64 - tambaqui frito & 101 & 8 & 8784 & 335 & 2562 & 108 & 3797 & 52 & 3677 & 202 & 396 & 5 & 18 & 1 \\
\hline
\end{tabular}




\section{Referências Bibliográficas}

Abalkhail, B.; Shawky, S. Prevalence of daily breakfast intake, iron deficiency anaemia and awarenees of being anaemic among Saudi school students. International Journal Food Science Nutrition, 53, p-519-528, 2002.

Abdulla, M. Assessment of food consumption. Scandinavian kJournal Gastroenterology, 14(52), p.28-41, 1979.

Abdulla, M.; Belbehoni, A.; Dashti, H. Dietary intake and biovailability of trace elements. Biology Trace Elements Research, v.21, p.173-178, 1989.

Abdulla, M.; Chmielnicka,J.. New aspects on the distribuition and metabolism of essential trace elements after dietary exposure toxic metals. Biology Trace Elements Research, v.23, p.2553, 1990.

Albuquerque, M. F. M.; Monteiro, A. M. Ingestão de alimentos e adequação de nutrientes no final da infância. Revista de Nutrição da PUCCAMP, 15:291-9, Campinas, 2002.

Albuquerque, M. F. M. Evaluation of the growth performance of female adolescents in Maceió - Brazil. Londres, 1993. 333p. Tese (Doutorado em Ciências) Universidade de Londres.

ACPO, Associação de Consciência à Prevenção Ocupacional. O Hg na Baixada Santista. Disponível em http://www.acpo.org.br/principal.php. Acesso em 25/abr/2006.

Alaimo, K.; Olson, C.M; Frongillo, E. A; Briefel, R.R.. Food insufficiency, family income, and health in US preschool and school-aged children. American Journal of Public Health, v.91, p. 781-786, 2001.

Alwan, A.. Cardiovascular diseases in the Eastern Mediterranean Region. World Health Statistics Quarterly, 46(2):97-100, 1993.

Amin-Zaki, L.; Elhassani, S.; Majeed, M.A; Clarkson, T.W.; Doherty, R.A; Greenwood, M. Intrauterine methylmercury poisoning in Iraq. Pediatrics, 54: 587-95, 1974.

Amancio, O. M, S.; Chaud, D. M. A. Dietas para perda de peso anunciadas na imprensa leiga. Cadernos de Saúde Pública, vol. 20, n.5, Rio de janeiro, 2004.

Anderson, R.A. Trace elements and cardiovasculares diseases. Acta Pharmacologica Toxicology, suppl 78, p.317-324, 1986.

ANVISA, Agência Nacional de Vigilância Sanitária. Legislação brasileira, portaria 685, 1998. 
AOAC - Association of Official Analytical Chemists. Official Methods of Analysis. $17^{\text {th }}$ ed., Washington: [s.n.], 1998, 1190 p.

Araújo-Lima, C.; Golding, M. Os frutos do tambaqui: ecologia, conservação e cultivo da Amazônia. Sociedade Civil Mamirauá, Brasília: CNPq, 1998.

Assis, AMO; Barreto ML. Condições de vida, saúde e nutrição na infância em Salvador. Salvador: UFBA; 2000.

Atlas Municipal, 2005. Desenvolvimento Humano em Manaus. Prefeitura Municipal de Manaus. Secretaria Municipal de Planejamento e Administração.

Azevedo, F.A. Toxicologia do Mercúrio. Ed. RIMa, São Carlos, cap. 2, 2003.

Bárány, E.; Bergdahl, I.A.; Bratteby, L.-E; Lindh, T. Samuelson, G., Skerfving, S.; Oskarsson, A.. Iron status influences trace element levels in human blood and serum. Environmental Research, 98, p-215-223, 2005.

Baratz, R, 2005. Dubious mercury testing. Quackwatch: your guide to quackery, health fraud and intelligent decisions. Disponível em : http://www.quackwatch.org/index.html. Acesso em $11 /$ jun/2006.

Barbosa, A. C.; Boischio, A. A.; East, G. A.; Ferrari, I.; Gonçalvez, A.; Silva, P. R. M. Mercury contamination in the Brazilian Amazon. Environment and occupational aspects. Water, Air, Soil Pollution, 80, p. 109-121, 1995.

Barbosa, A.C.; Dórea, J.G. Índices of mercury contamination during breast feeding in Amazon Basin. Environmental Toxicology and Pharmacology, 6, p. 71-79, 1998.

Barbosa, AC.; Jardim, W.; Dorea, J.G.; Fosberg,B., Souza, J. . Hair mercury speciation as a function of gender, age and body mass index in inhabitant of the Negro River Basin, Amazon, Brazil. Archives of Environmental Contamination and Toxicology, 40, p. 439 - 444, 2001.

Barreto, S.A.J.; Cyrillo, D.C. Análise da composição dos gastos com alimentação no Município de São Paulo (Brasil) na década de 1990. Revista de Saúde Pública, São Paulo, v. 35, n. 1, p. 52 $-59,2001$.

Batistella, A.M.; Castro, C.O.; Vale, J.D. Conhecimento dos moradores da comunidade de Boas Novas, no lago Janauacá - Amazonas, sobre os hábitos alimentares dos peixes da região. Acta Amazônica, vol. 35(1) 51-54, 2005. 
Baxter, M.J. Exploratory multivariate analysis in archaeology. Edinburgh University Press, $1994^{\mathrm{a}}$, cap. 4, principal component analysis - specialised topics, p. 63-94.

Baxter, M.J. Exploratory multivariate analysis in archaeology. Edinburghb University Press, $1994^{\text {b }}$, cap. 9, discriminant analysis, p. 185-188.

Beharav, A.; Nevo, E. Predictive validity ofdiscriminant analysis for genetic data. Genetica, 119:259-267, 2003.

Belger, L. Influência de alguns fatores ambientais sobre o nível de mercúrio em Cichla spp. e Hopias malabaricus na bacia do Rio Negro. Dissertação de Mestrado, Instituto Nacional de Pesquisas da Amazônia, Manaus, Brasil, 2001.

Beharav, A.; Nevo, E. Predictive validity of discriminant analysis for genetic data. Genetica, 119:259-267, 2003.

Bisinoti, M.C. Biogeoquímica aquática do mercúrio orgânico na bacia do rio Negro, Amazônia. 2005. Tese (Doutorado) - Universidade Estadual de Campinas, São Paulo.

Black, R.E; Sazawal, S. Zinc and childhood infectious disease morbidity and mortality. Britsh Journal Nutrition; 85:125-9, 2001.

Bode, P., 1996. Instrumental organizational aspects of neutron activation analysis laboratory. Delft University of Technology, Delft: The Netherlands, p: 147.

Boischio, A. A. P.; Henshel, D. Fish consumption, fish lore and mercury pollution - risk communication for the Madeira River people. Environmental Research., Section A 84, p.108-126, 2000.

Book Review, Nutrition an Chemical Toxicity. Toxicology. 154, p. 139-140, 2000.

Bonomo, E. Como medir a ingestão alimentar? In: Dutra de Oliveira JE. Obesidade e anemia carencial na adolescência. São Paulo: Instituto Danone, 2000.

Brasil, Conselho Nacional do Meio Ambiente. Resolução CONAMA na 20: Estabelece a classificação das aguas e os níveis de qualidade exigidos. Disponível em http://www.mma.gov/port/conama/res/res86/res2086.html. Acesso em: 27/maio/2006.

Campos, M.S. Estudo da correlação mercúrio-selênio em amostras de cabelos de índios Wari. Dissertação (Mestrado), Instituto de Pesquisas Energéticas e Nucleares, IPEN, São Paulo, 2001. 
Campos, M. S.; Sarkis, J. E. S.; Muller, R. C. S.; Brabo, E. S.; Santos, E. O. Correlation between mercury and selenium concentrations in Indian hair from Rondônia State, Amazon region, Brazil. The Science of the Total Environment. 287, p. 155-161, 2002.

Cardoso, R. S.; Batista, V. S.; Júnir, C. H. F.; Martins, W. R. Aspectos econômicos e operacioanis das viagens da frota pesqueira de Manaus, Amazônia Central. Acta Amazônica, v. 34 (2), p. 301-307, 2004.

Carneiro, R.L., Silva, J.A.M.,Albinati, R.C.B., Socorro, E.P., Neves, A.P. Uso de microcrustáceos (Dendrocephalus brasiliensis) na ração para tucunaré. Revista Brasileira Saúde e Produção Animal, v.5, n.1, p. 18 - 24, 2004.

Carvalho, C.E.V., Lacerda, L.D. \& Gomes, M. P. Metais pesados na biota bentônica da Baía de Sepetiba e Angra dos Reis, RJ. Acta Limnology. Brasil, 6, p. 222-229, 1993.

Carvalho, L.E. Nutrição e desnutrição na Amazônia: dos mitos à dura realidade. Boletim SBCTA, v.23, n.1/2, p.1-11, 1989.

Carvalho, M.S.; Bezerra Neto, P.S.; Manzo, S. P. Pobreza e desnutrição no Brasil: Avaliação do Programa "Incentivo ao Combate às Carências Nutricionais (ICCN)". Cadernos de Debate, vol. X,p. 25-42, 2003.

Castoldi, A. F.; Coccini, T.; Manzo, L. Neurotoxic and molecular effects of methylmercury in humans. Reviews Environmental Health, 18(1), p. 19-31, 2003.

Cavalcante, A AM.; Priore, S.E.; Franceschini, S. C. C. Estudos de consumo alimentar: aspectos metodológicos gerais e o seu emprego na valiação de crianças e adolescente. Revista Brasileira de Saúde Materno Infantil., Recife, 4 (3), p. 229-240, 2004.

CETESB, Companhia de Tecnologia de Saneamento Ambiental. Avaliação preliminar da contaminação por metais pesados na água, sedimento e organismos aquáticos do Rio Cubatão (SP). Relatório Técnico CETESB. 28 p. mais anexos. (1989).

CETESB, Companhia de Tecnologia de Saneamento Ambiental. Contaminantes na Bacia do rio Cubatão e seus Reflexos na Biota Aquática. Relatório Técnico CETESB. 81p. mais anexos e mapas. (1990).

CETESB, Companhia de Tecnologia de Saneamento Ambiental. Programa de controle de poluição programa de assistência técnica sistema estuarino de Santos e São Vicente. Relatório Técnico CETESB. 141p. mais anexos e mapas. (2001). 
Chang, C. C.; Gutenmann, W. H.; Reid, C. M.; Lisk, D. J. Selenium content of Brazil nuts from two geographic locations in Brazil. Chemosphere, v. 30, n. 4, p. 801-802, 1995.

Chen, J.; Gao, J. The chinese total diet study in 1990. Part II. Nutrients. Journal of Association of Official Analytical Chemists International, v.76, n.6, p.1206-1213, 1993.

Choi, A.; Budtz-Jorgensen, E.; Jorgensen, P. J., Weihe, P.; Grandjean, P. Selenium as a potential protective factor against marcury developmental neurotoxicity. In: " $\boldsymbol{s}^{\text {th }}$ International Conference on Mercury as a Global Pollutant”. Madison Wisconsin, august 6-11, 2006. Resumos (www.mercury2006.org).

Christakis, G. Nutritional assessment in health programs. American Journal of Public Health; 63 (Suppl), p. 1-82, 1973.

Cordeiro, M.B.C. Adequação alimentar e avaliação do estado nutricional em relação ao zinco em grupos de idosos institucionalizados. São Paulo: 1994. Dissertação (Mestrado) Universidade de São Paulo.

Corsino, E.L. Introducción a la Nutrición Y Nutrición Deportiva: Conceptos Básicos. Universidad Interamericana de PR - Metro, Facultad de Educación, Dept. de Educación Física, 2000. Disponível em http://www.saludmed.com/Documentos/Intr_NuD.htm. Acesso em 02/abr/2006.

Cozzolino, S. M. F. Biodisponibilidade de nutrientes. Barueri, SP: Manole, p. 654, 2005.

Cruz, A.T.R. O consumo alimentar de crianças: avaliação pelo "método da pesagem direta" em três creches no Município de São Paulo - SP. Dissertação (Mestrado). São Paulo: Faculdade de Ciências Farmacêuticas da Universidade de São Paulo, 2001.

Currie, L.A. Limits for qualitative detection and quantitative determination - Application to Radiochemistry. Analytical Chemistry, v. 40, n. 3, p. 586 - 593, 1968.

Currie, L.A. Detection and quantification limits: origins and historical overview. Analytical Chemistry Acta, v. 391, p. 127 - 134, 1998.

Dantas. R. P.; Cozzolino, S.M.F. Biodisponibilidade de zinco em dieta regional de São Paulo Archivos Latinoamericanos de Nutrición, v.40 n.2, p. 221-230, 1990.

Dias, N. M. F.S. Minamata - Case Study. Ambicare Industrial Tratamento de Resíduos, S.A. Dept $^{\circ}$ de Ambiente, 2004. 
Diretiva, 2000/60/CE do Parlamento Europeu e do Conselho de 23 de Outubro de 2000 que estabelece um quadro de ação comunitária no domínio da política da água, JO L 327 de 22.12.2000, alterada pela Decisão no 2455/2001/CE do Parlamento Europeu e do Conselho de 20 de Novembro de 2001 que estabelece a lista das substâncias prioritárias no domínio da política da água, JO L 331 de 15.12.2001.

Dolbec, J.; Mergler, D.; Larribe, F.; Roulet, M.; Lebel, J.; Lucotte, M. Sequencial analisys of hair marcury levels in relation to fish diet of an Amazonian population, Brazil. The Science of the Total Environment, 271, p. 87-97, 2001.

Dorea, J.G.; Moreira, M.B.; East, G.; Barbosa. AC. Selenium and mercury concentration some fish species of the Madeira River, Amazon Basin, Brazil. Biology Trace Elements Research. 65, p. 211-220, 1998.

Dorea, J. Fish are central in the diet of Amazonian riparians: should we worry about their mercury concentrations? Environmental Research 92 ,p. 232-244, 2003.

Dorea, J.G.; Souza, J.R.; Rodrigues, P., Ferrari, I.; Barbosa, AC. Hair mercury (signature of fish consumption) and cardiovascular risk in Mundurubu and Kayabi Indians of Amazonia. Environmental Research 97, p.209-219, 2005.

Dorea, J. G.; Barbosa, AC.; Silva, G.S. Fish mercury biacumulation as a function of feeding behavior and hydrological cycles of the Rio Negro, Amazon. Comparative Biochemistry and Physiology, Part C, 142,p. 276-283, 2006.

DRI, Institute of Medicine. Dietary Reference Intakes for Calcium, Phosphorus, Magnesium, Vitamin D, and Fluoride (2003). http://www.nap.edu, copyright 1997, The National Academy of Science.

DRI, Institute of Medicine. Dietary Reference Intakes for Vitamin A, Vitamin K, Arsenic, Boron, Chromium, Copper, Iodine, Iron, Manganese, Molybdenum, Nickel, Silicon, Vanadium, and Zinc (2000a), http://www.nap.edu,. The National Academy of Science.

DRI, Institute of Medicine. Dietary Reference Intakes for Vitamin C, Vitamin E, Selenium, and Carotenoids (2000b). http://www.nap.edu, copyright 1997, The National Academy of Science.

DRI, Institute of Medicine. Dietary Reference Intakes for Water, Potassium, Sodium, Chloride, and Sulfate (2004) http://www.nap.edu, copyright 2003. The National Academy of Science. 
Enes, C. C. Disponibilidade de energia e nutrientes nos domicílios: o contrate entre as regiões Norte e Sul do Brasil. Dissertação (Mestrado). Escola Superior de Agricultura "Luiz de Queiroz”. Universidade de São Paulo, Piracicaba, 2005.

Environmental Research, Sectiona 77, 67 (1998) Article nº ER983848.

EPA (US. Environmental Protection Agency), 1997. Mercury study for Congress. Vol. I. Executive Summary. EPA-452/R-97-003. U. S. Environmental Protection Agency, Office of Air Quality Planning and Standards and Office of Research and Development.

EPA (US. Environmental Protection Agency), 2006. Mercury in Medical Facilities. Revised August 10, 2003; Updated June 23, 2005. Disponível em http://www.epa.gov/grtlakes/seahome/mercury/src.htm. Acesso em 12/jun6/2006.

EURACHEM/CITAC Guia, "Determinando a incerteza nas medições analíticas". Versão brasileira. Editores: Ellison, S.L. R; Rosslein, M. and Williams, A., 2nd Ed., 2002.

Fadini, P. S. Comportamento biogeoquímico do Hg na bacia do rio Negro (AM). Tese (Doutorado). Universidade Estadual de Campinas - UNICAMP, Instituto de Química, 1999.

Fadini, P. S.; Jardim, W. F.. Is the Negro River Basin (Amazon) impacted by naturally occurring mercury? The Science of the Total Environment, 175, p. 141-150, 2001.

Faganello, C.R.F. Disponibilidade de energia e nutrientes para a população das regiões metropolitanas de Recife e São Paulo, 2002. Dissertação (Mestrado). Escola Superior de Agricultura “Luiz de Queiroz”, Universidade de São Paulo.

Fávaro D.I.T; Maihara V.A, Armelin,M.J.A., Vasconcellos M.B.A; Cozzolino S.M.F. "Determination of As, C, Cr, Cu, Hg, Sb and Se concentrations by Radiochemical neutron Activation Analysis in differente Brazilian Regional diets”. Journal of Radioanalytical and Nuclear Chemistry, vol 181(2), p.385-394, 1994.

Fávaro, D.I.T; Hui, M.I.T.; Cozzolino, S.M.F.; Maihara, V.A.; Vasconcellos, M.B.A.; Yuyama, L.K.; Boaventura, G.T.; Tramonte, V.L. "Determination of various nutrients and toxic elements in differents Brazilian regional diets by neutron activation analysis". Journal of Trace Elements in Medicine and Biology, vol 11, p.129-136, 1997.

Fávaro, D.I.T; Maihara, V.A.; Mafra, D; Souza, S.A; Vasconcellos, M.B.A.; Cordeiro, M.B.C.; Cozzolino, S.M.F.. Application of NAA to the determination of mineral and trace elements in 
Brazilian diets at IPEN/CNEN-SP. Journal of Radioanalytical and Nuclear Chemistry, 244, n.1, p.241-245, 2000a.

Fávaro, D.I.T; Afonso, C.; Vasconcellos, M. B.A. Cozzolino, S. M. F. Determinação de elementos minerais e traço por ativação neutrônica, em refeições servidas no restaurante da Faculdade de Saúde Pública/USP. Revista Ciência e Tecnologia de Alimentos, Campinas, 20 (2), p. 176$182,2000 \mathrm{~b}$.

Feng, X., Sommar, J., Lindqvist, O., Hong, Y. Occurrence, emissions and deposition of mercury during coal combustion in the province Guizhou, China. Water, Air, Soil Pollution, 139, p. 311-324, 2001.

Fisberg, M.; Bandeira, C.R.S.; Bonilha, E. A.; Halpen, G. Hábitos alimentares na adolescência. Pediatria Moderna, 36, p. 66-70, 2000.

Fontanive R.S.; Costa, R.S.; Soares, E.A. Comparison between the nutricional status of eutrophic and overweight adolescents living in Brazil. Nutrition Research, 22, p.667-678, 2002.

Franco, G. Tabela de Composição Química dos Alimentos. 9. ed. Rio de Janeiro: Livraria Atheneu, 1992.

FVA, Fundação Vitória Amazônica, 1998. Plano de Manejo do Parque Nacional do Jaú. Versão 8 Manaus: FVA/IBAMA. XVIII, 258p. il.

Galvão, L.A; Corey, G. Hg. Metepec, México: ECO-Centro Panamericano de Ecologia Humana Y Salud/OPS/OMS, 82 p. Série Vigilância, n. 7, 1987.

Garcia, L.Y.C.; Mota, A.C.A.; Filho, V.O.; Vaz, F.A.C. Anemias carenciais na Infância. Pediatria 20(2), p. 112-125, 1998.

Garcia, G.C.B.; Gambardella, A.M.D.; Frutuoso, M. F. P. Estado nutrional e consumo alimentar de adolescentes de um centro de juventude da cidade de São Paulo. Revista de Nutrição, v.16, p. 41-50, 2003.

Gardfeldt, K; Munthe, J.; Stromberg, D.; Lindqvist, O. A. Kinetic study on the abiotica methylation of divalent mercury in the aqueous phase. The Science of the Total Environment, 304, p. 127-136, 2003.

Geier, M.R.; Geier, D.A. Thimerosal in Childhood Vaccines, Neurodevelopmental Disorders, and Heart Disease in the United States. Journal of American Physicians and Surgeons, 8(1), p. 6-11, 2003. 
Gertjan, J.M.; Guido, R.M.M.; Haenen, E. B.; Wim J.F; Van der Vijgh; Bast, A. Lecithinized copper,zinc-superoxide dismutase as a protector against doxorubicin-induced cardiotoxicity in mice. Toxicology and Applied Pharmacology, Volume 194, Issue 2, p. 180-188, 2004.

Gibicar, D.; Horvat, M.; Nakou, S.; Sarafidou, J.; Yager, J. Pilot study of intrauterine exposure to methylmercury in Eastern Aegean islands, Greece. The Science of the Total Environment, 2006, IN PRESS.

Gilbertson, M. Male cerebral palsy hospitalization as a potential indicator of neurological effects of methylmercury exposure in Great Lakes communities. Environmental Research, Volume 95, Issue 3, p. 375-384, 2004.

Giugliano, R.; Shrimpton, R.; Arkcoll, D.B.; Giugliano, L.G.; Petrere, J.R.M. Diagnóstico da realidade alimentar e nutricional do Estado do Amazonas, 1978. Acta Amazônica, 2, p.47-48, 1978.

Gorski, P.; Cleckner, L.B., Hurley, J., Sierszen, M.; Armstron, D.. Factors affecting enhanced mercury bioaccumulation in inland lakes of Isle Royale National Park, USA. The Science of the Total Environment, 304, p. 327-348, 2003.

Grandjean, P.; Weithe, P.; Nielsen, J.B. Methylmercury: significance of intrauterine and postnatal exposures. Clinica Chimica Acta. 40, p.1395-1400, 1994.

Grandejean, P. ; Jorgensen,P.J.; Weithw, P. Validity of mercury exposure biomarkers. In: Wilson, S. H. Suk, Wa.A (EDs), Biomarkers of Environmentally Associated Disease. CRC. Press Lewis. Boca Raton. , p. 235-247, 2002.

Guimarães-Klautau, M. N.; Ascenção, R. D.; Caldart, F. A.; Grisolia, C. K.; Souza, J.; Barbosa, A.; Cordeiro, C.M.T.; Ferrari, F. Analysis of genetic susceptibility to mercury contamination evaluated throug molecular biomarkers in at-risk Amazon Amerindin populations. Genetics and Molecular Biology, 28( 4), p. 827-832, 2005.

Hacon, S.; Rochedo, E. R R.; Campos, R. R. R.; Lacerda, L. D. Mercury exposure through fish consumption in the urban area of Alta Floresta in the Amazon Basin. Journal of Geochemical. Exploration, 58, p. 206-209, 1997.

Hambidge M. Human zinc deficiency. Journal of Nutrition; 130 Suppl., p.1344-1349, 2000.

Harada, Y. Feral methylmercury poisoning. In: TsubakiK.; Irukayma, K.; editor. Minamata Disease. Amsterdam: Elsevier Science Publishers; chap. 3, 1977. 
Hart, B.T. Trace metal complexing capacity of natural waters: review. Science Technology Letter, 62, p.3-12, 1981.

Haswell, S. J. Atomic Absorption Spectrometry. Theory, Design and Applications. Amsterdam - Elsevier, 1991.

Hatch, W. R. \& Ott, W. L.. Determination of sub-microgram quantities of mercury by atomic absorption spectrophotometry. Analytical Chemistry 40 (14), p. 2085, 1968.

Horvat, M. Mercury analysis and speciation. In Environmental Sample in Global and Regional Marcury Cycles: Sources, Fluxes and Mass Balances, p. 1-31, W. Baeyens et al (eds), 1996.

Holsbeek, L; Das, H.K.; Joiris, C.R. Mercury in human hair and relation to fish consumption in Bangladesh. The Science of the Total Environment., v. 186 (3), p.181-188, 1996.

Hylander, L. D., Meili, M. 500 years of mercury production: global annual inventory by region until 2000 and associated emissions. The Science of the Total Environment, 304, p.13-27, 2003.

IAEA - International Atomica Energy Agency. Reference Methods for Marine Pollution Studies. Vienna: 1987, IAEA, (IAEA-MEL-46).

IAEA - International Atomica Energy Agency. Practical aspects of operating a neutron analysis laboratory, International Atomic Energy Agency, TECDOC - 564 , 1990, Vienna.

IBAMA, Instituto Brasileiro do Meio Ambiente e dos Recursos Naturais Renováveis. Disponível em http://www.ibama.gov.br/pescaamadora/inicio/home.htm. Acesso em 12/maio/2006.

IBGE, 1977. Instituto Brasileiro de Geografia e Estatística. Estudo Nacional de Despesa Familiar: dados preliminares, consumo alimentar, antropometria. 4.ed. Rio de Janeiro, 1977.

IBGE, 2004. Instituto Brasileiro de Geografia e Estatística. Pesquisa de Orçamentos Familiares 2002/2003.

IBGE, 2005. Instituto Brasileiro de Geografia e Estatística. IBGE Cidades@. Disponível em http://www.ibge.gov.br. Acesso em 22/ago/2006.

INMETRO DOQ-CGCRE-008. Orientações sobre validação de métodos de ensaios químicos, 2002, RJ, BRASIL.

Instituto Sócio Ambiental. UNESCO amplia sítio do Patrimônio Natural da Humanidade na Amazônia. Notícias: Unidades de Conservação, 08/07/2003. 
International Atomic Energy Agency, IAEA (1997). Certificate of Analysis Reference Material Human Hair (IAEA-085). Analytical Quality Control Services.

International Atomic Energy Agency, IAEA (1997). Certificate of Analysis Reference Material Human Hair (IAEA-086). Analytical Quality Control Services.

International Atomic Energy Agency, IAEA (2003). Certificate of Analysis Reference Material Fish Tissue (IAEA-407). Analytical Quality Control Services.

Kehrig, H..A.; Malm, O.; Akagi, H. Methylmercury in hair samples from different riverine groups, Amazon, Brazil. Water Air Soil Pollution, 97, p. 17-29, 1997.

Lacerda, L.D.; Teixeira, V.I.; Guimarãoes, V. R. D. Seazonal variation of heavy metals in seaweeds from Conceição de Jacareí. Revista Brasileira Biologia Marinha. 49 (3), p.847 - 849, 1985.

Lacerda, L.D.; Pfeiffer, W.C. Mercury from gold mining in the Amazon environment - an overview. Química Nova, 15, p. 155-160, 1992.

Lajolo, F.M.; Menezes, E.W. Tabela brasileira de composição de alimentos. Projeto integrado de composição de alimentos, 2005. Disponível em http://www.fcf.usp.br/tabela. Acesso em 01/maio/2006.

Lechler, P.J.; Miller, J. R.; Lacerda, L. D.; Vinson, D.; Bonzongo, J. C.; Lyons, W. B.; Warwick, J. J. Elevated mercury concentrations in soils, sediments, water and fish of the Madeira River basin, Brazilian Amazon: a function of natural enrichments?. The Science Total Environment, 260, p. 87-96, 2000.

Lemire, M.; Mergler, D.; Fillion, M.; Passos, C. J. S.; Guimarães, J. R.D.; Davidson, R.; Lucotte, M. Blood selenium and mercury relation in the brazilian amazon. In: " $\theta^{\text {th }}$ International Conference on Mercury as a Global Pollutant”. Madison Wisconsin, august 6-11, 2006. Resumos (www.mercury2006.org).

Lerner B.R.; Lei, D.L.M.; Chaves, S.P.; Freire, R.D. O cálcio consumido por adolescentes de escolas públicas de Osasco, São Paulo. Revista de Nutrição, 13, p.57-63, 2000.

Levander, O.A. Human selenium nutrition and toxicity. In: Mertz, W.; Albernoth, C.O.; Olin, S.S. (Eds.) Risk assessement of essential elements. Washington: ILSI Press, p.147-155, 1994.

Levander, O.A.; Burk, R.F. Selenio. Em: Organización Mundial de la Salud/Organización Panamericana de la Salud. Conocimientos actuales sobre nutrición. 7a ed. Washington, DC: ILSI Press, p. 342-351. (Publicación Científica 565), 1997. 
Lima, A.P. S. Avaliação do impacto de uma atividade garimpeira no município de Cachoeira do Piriá, Estado do Pará. CNEN/IPEN. São Paulo: 2005. Tese (Doutorado) - Universidade de São Paulo.

Lindqvist, O; Johansson, K.; Aastrup, M.; Andersson, A.; Bringmark, L.; Hovsenius, L.; Iverfeldt, A A; Meili, M.; Timm, B. Mercury in the Swedish Environment: recent research on causes, consequences and corrective methods. Kluwer Academica Publishers, Dordrecht, The Netherlands. Reprinted from Water, Air and Soil Pollution, 55, p. 1-2, 1992.

Lisk, D. J.; Ip, C. Characterization of tissue selenium profiles and anticarcinogenic responses in rats fed natural sources of selenium-rich products. Carcinogenesis, v.14, n. 4, p. 573-576, 1999.

Lopes, A.C. S.; Caiaffa, W.T.; Sichieri, R.; Mingoti, S. A; Lima-Costa, M. F. Consumo de nutrientes em adultos e idosos em estudo de base populacional: projeto Bambuí. Cadernos de Saúde Pública, 21(4):1201-1209, Rio de Janeiro, 2005.

Lucena, M.A.F.; Bazante, M.O.; Torres, M.A.A.; Batista Filho, M. Padrões alimentares de famílias rurais do trópico semi-árido (Nordeste do Brasil). Alimentação e Nutrição, São Paulo, v.5, n.6, p.51-58, 1964.

Maihara V.A.; Miguel, AT.S.; Vasconcellos, M.B.A., 1995 "Determinação de elementos traço essenciais em dietas de crianças de idade pré-escolar”. Anais do III Encontro de Aplicações Nucleares - ENAN, Águas de Lindóia/SP, Vol. II, p. 1248-53, 1995.

Maihara, V.A. Avaliação do conteúdo de alguns elementos essenciais e tóxicos em dietas de crianças $e$ idosos pelo método de análise por ativação com nêutrons. CNEN/IPEN. São Paulo: 1996. Tese (Doutorado) - Instituto de Pesquisas Energéticas e Nucleares.

Maihara, V.A.; Vasconcellos, M.B.A.; Cordeiro, M.B.; Cozzolino, S.M.F. "Estimate of toxic element intake in diets of pre-school children and elderly collected by duplicate portion sampling". Food Additives and Contaminants, 15(7), p.782-788, 1998.

Malm, O. Avaliação da contaminação ambiental por mercúrio através da análise de peixes. In: Mercúrio em Áreas de Garimpo de Ouro, Série vigilância 12, ed. Câmara, V., Centro Panamericano de Ecologia e Saúde Humana, OPAS/OMS, Metepec, México D.F., p.81-98, 1993. 
Malm, O.; Branches, F. J. P.; Akagi, H.; Castro, M. B.; Pfeiffer, W.; Harada, M.; Bastos, W. Kato, H. Mercury and methylmercury in fish and human hair from the Tapajós river basin, Brazil. The Science Total Environment, 260, p. 87-96, 1995.

Malm, O.; Guimarães, J. R. D.; Castro, M. B.; Bastos, W. R.; Viana, J. P.; Branches, F. J. P.; Silveira, E. G.; Pfeiffer, W. C. Follow-up of mercury levels in fish, human hair and urine in the Madeira and Tapajós basins, Amazon, Brazil. Water, Air, Soil Pollution. 97, p. 45-51, 1997.

Marchioni, D.M.L; Slater, B.; Fisberg, R.M. O estudo da dieta: considerações metodológicas. Cadernos de Debate., Volume X, p. 62-76, 2003.

Marchioni, D.M.L; Slater, B.; Fisberg, R.M. Aplicação das Dietary Reference Intakes na avaliação da ingestão de nutrientes para indivíduos. Revista de Nutrição, Campinas, 17(2), p.207-216, 2004.

Marsh, D.O.; Clarkson T.W.; Cox, C.; Myers, G.J.; Amin-Zaki, L.; Al-Tikriti, S. Fetal methylmercury poisoning. Relationship between concentration in single strands of maternal hair and child effects. Archives of Neurology, 44, p. 1017-22, 1987.

Matsumoto H.; Koya, G.; Takauchi, T. Fetal Minamata disease. Journal Neuropathology Experimental Neurology; 24, p.563-574, 1965.

Maurice-Bourgoin, L., Quiroga, I.; Chincheros, J., Courau, P. "Mercury distribution in waters and fishes of the upper Madeira rivers and mercury exposure in riparian Amazonian populations". The Science of the Total Environment, 260, p.73-86, 2000.

Mazzili, R.N. Valor nutricional da merenda escolar e sua contribuição para as recomendações nutricionais do pré-escolar matriculado em CEAP. Revista de Saúde Pública, São Paulo, v.21, p.246-254, 1987.

Meech, J.A.; Veiga, M.M.; Tromasns, D. Emissions and stability of mercury in the Amazon. Canadian Metallurgical Quaterly, v. 36, n.4, p. 231-239, 1997.

Mergler, D.; Boischio, A.A; Branches, F.; Morais, S.; Passos, C.J.; Gaspar, E.; Lucotte, M.. Neurotoxic Sequelae of Methylmercury exposure in the brazilian amazon: a follow-up study. $6^{\text {th }}$ Internation Conference on Hg as a Global Pollutant, Minamata, 2001.

Miretzky, P. Bisinoti, M.C.; Jardim, W. F. Sorption of mercury (II) in Amazon soils from column studies. Chemosphere, 2005, IN PRESS. 
Mitra, S. Mercury in the ecosystem. Switzerland: Transtetech Pubis, 327 p., 1986.

Moreira, E. G.; Vasconcellos, M.B.A.; Paiva, R.P.; Saiki, M. Utilização de gráficos de controle para verificação da estabilidade de balanças analíticas e determinação da incerteza associada à pesagem. METROLOGIA - 2003. Sociedade Brasileira de Metrologia (SBM). Setembro 01-05, 2003, Recife, Pernambuco - Brasil.

Mucci, A; Lucotte, M.; Montgomery, S.; Plourde, Y.; Pichet, P.; Vantra, H. Mercury remobilization from flooded soils in a hydroelectric reservois of Northern Quebec, La Grande-2-results of a soil resuspension experiment. Canadian Journal of Fisheries and Aquatic Sciences, v.52, n.11, p.2507-2517, 1995.

Nascimento, E. S.; Chasin, A. A. M.; Ecotoxicologia do Hg e seus compostos, Salvador: CRA., 2001.

Nascimento, G. Análise da mortalidade por homicídios no município de Manaus segundo sua evolução histórica e fatores sócio-econômicos, institucionais e espaciais de determinação.

Dissertação (Mestrado). Programa de Desenvolvimento Regional da Faculdade de Estudos Sociais. Universidade Federal do Amazonas, 2005.

National Research Council, 1989. Recommended dietary allowances, 10th ed. Washington, DC, National Academy Press.

National Research Council. Toxicological Effects of Methylmercury. Committee on the Toxicological Effects of Methylmercury, Board on Environmental Studies and Toxicology, Commission on Life Sciences, National academy Press, Washington, DC (www.nap.edu), 2000 .

NBR ISO 9004. Quality management systems - guidelines for performance improvements. ABNT/CB-25, ISSO 9004: 2000.

National Institute of Standards and Technology, NIST (1977). Certificate of analysis, Standard Reference Material 1571, Orchard Leaves, USA. 
National Institute of Standards and Technology, NIST (1993). Certificate of analysis, Standard

Reference Material 1566b, Oyster Tissue, USA

National Institute of Standards and Technology, NIST (1995). Certificate of analysis, Standard Reference Material $\mathbf{1 5 7 3}^{\mathrm{a}}$, Tomato Leaves, USA.

National Institute of Standards and Technology, NIST (1998). Certificate of analysis, Standard Reference Material 1548 ${ }^{\mathrm{a}}$, Typical Diet, USA.

National Research Council of Canada, NRCC (1986). Certificate of analysis, Reference material DORM-1, Dog Muscle Materials for Trace Elements, Canada.

Oliveira. R. \& Anderson. E. S. (1999). Gênero Conservação e Participação Comunitária: O caso do Parque Nacional do Jaú. Estudo de Caso. No. 2. MERGE. University of Florida.

Oliveira, S. M. B; Melfi, A J., Fostier, A H.; Forti, M. C., Favaro, D. I. T; Boulet, R.. Soils as an important sink for mercury in the Amazon. Water, Air and Soil Pollution, 26, p. 321-337, 2001.

OPS. Organização Panamericana de Saúde, Compuestos de hierro para la fortificación de alimentos: Guías para América Latina y el Caribe. Washington, D.C.: OPS, (C) 2002.

O’Reilly, S.; Drash, G.; Beinhoff, C.; Maydl, S.; Vosko, M.R., Roider, G.; Dzaja, D. The Mt. Diwata study on the Philippines - treatment of mercury intoxicated inhabitants of a gold mining area with DMPS (2,3-Dimercapto-1-propane-sulfonica acid, Dimaval. The Science of the Total Environment, 30, p.71-82, 2000.

Otten, J. J., Hellwig, J. P., Meyers, L. D. Dietary Reference Intakes: The Essential Guide to Nutrient Requirements, 560 páginas, 2006.

Pascalicchio, A.A. E. Contaminação por metais pesados: saúde pública e medicina ortomolecular. São Paulo: Annablume, 2002.

Pellegati, F. Determinação de metais pesados e outros elementos em sedimentos da baía de Sepetiba (RJ), por ativação neutrônica. 2000, Dissertação (Mestrado) - Instituto de Pesquisas Energéticas e Nucleares, IPEN, São Paulo.

Pestana, M.H.D.; Formoso, M.L.L. Mercury contamination in Lavras do Sul, south Brazil: a legacy from past and recent gold mining. The Science of the Total Environment , 307, p. 125-140, 2003.

Pezzuti, J. C. B. Ecologia e etnoecologia de quelônios no Parque Nacional do Jaú, Amazonas, Brasil. Tese (Doutorado) - Universidade Estadual de Campinas, Instituto de Biologia, 2003. 
Pfeifer, W. C.; de Lacerda, L. D.; Malm, O.; Souza, C. M. M.; da Silveira, E. G.; Bastos, W. R.; Mercury concentrations in Island waters of gold mining areas in Rondonia, Brazil. The Science of the Total Environment, 87/88, p. 233-.240, 1989.

Philippi, S.T.; Ribeiro, L.C.; Latterza, A.R.; Cruz, A.T.R. Pirâmide alimentar adaptada: guia para escolha dos alimentos. Revista de Nutrição; 12(1), p.65-80, 1999.

Pinheiro, M.C.N.; Muller, R.C.S.; Sarkis, J.E.; Vieira, J. L.F.; Oikawa, T.; Gomes, M.S.V.; Guimarães, G.A.; Nascimento, J. L.M.; Silveira, L.C.L. Mercury and selenium concentrations in hair samples of women in fertile age from Amazon riverside communities. The Science of the Total Environment, 349, p. 284-.288, 2005.

Poluektov, N. S.; Zelyukova, Y. V. Atomic absorption determination of mercury microcontaminations in alkali metal hydroxides (exchange of experience). Industrial Laboratory, 35 (2), p. 222-230, 1969.

Prefeitura de Manaus. Manaus, 2006 (http://www.manaus.am.gov.br).

Reddy,S.B.; Charles,M.J.; Naga,G.J.; Vijayan, R,V.; Seetharami,B., Ravi,M.; Sundareswar,B. Trace elemental analysis of carcinoma kidney and stomach by PIXE method. Nuclear Instruments and Methods in Physics Research B 207:345 .355, 2003.

Redwood,L., Bernard, S.; Brown, D.Predicted mercury Concentrations in Hair from Infant immunizations: cause for concern. Neuro Toxicology 22, 691-697, 2001.

Reilly C. Selenium in food and health. New York: Blackie Academic \& Professional; 1996.

Relatório da Federação dos Pescadores do Amazonas e Roraima. Perfil econômico do setor pesqueiro do Estado do Amazonas. Manaus, 1998. 10p. (Relatório).

Ribeiro, P.; Morais, T.B.; Colugnati, F.A.B.; Basile, F.A.; Sigulem, D.M. Tabelas de composição química de alimentos: análise comparativa com resultados laboratoriais. Revista de Saúde Pública, v. 37, n.2, p.216-225, 2003.

Romani, S.A.M., Amigo, H. Perfil alimentar e posse de terra na área rural do estado de Pernambuco, Nordeste do Brasil. Revista de Saúde Pública, São Paulo, v.20, n.5, p.369-376, 1986.

Roulet, M.; Lebel, J.; Mergler, D.; Lucotte, M.; Larribe, F. Fish diet and mercury exposure in a riparian Amazonian population. Water, Air and Soil Pollution. 97, p.31-44, 1997. 
Roulet, M.; Lucotte, M.; Guimarães, J.R.D.; Rheault, I. Methylmercury in water, seston, and epiphyton of an Amazonian river and its flooplain, Tapajós River, Brazil. The Science of the Total Environment, 261, p. 43-59, 2000.

Saiki, M.; Vasconcellos, M.B.A.; Arauz, L.J., Fulfaro, R. Mercury contamination in humans linked to river chemistry. AMBIO, Stockholm, v.28, p.519-521, 1998.

Salati, E.; dos Santos, A.; Lovejoy, T. E.; Klabin, I. Por que Salvar a Floresta Amazônica. Instituto Nacional de Pesquisas da Amazônia (INPA), Manaus, Amazonas. 108 p, 1998.

Salazar, C. Comunidades periféricas: ecología y taxonomia. Sección Biogeoquímica: Laboratorio Comunidades Acuáticas. Instituto de Zoología Tropical. Facultad de Ciencias. Universidade Central de Venezuela. Caracas. Disponível em http://www.ciens.ucv.ve/instzool/BioGQCS.html. Acesso 01/08/2006.

Salvo, V.L; M.A; Gimeno; S.G.A. Métodos de investigação do consumo alimentar: entrevista: 2003. Disponível em http://www.nutricaoempauta.com.br/layout impressao.php?cod=363. Acesso 01/maio/2006.

Sandström, B. Bioavailability of Zinc. European Journal of Clinical Nutrition; 51(Suppl 1):S17S9.5, 1997.

Santos, E. C. O; Jesus, I. M.; Brabo, E. S.; Loureiro, E. C. B.; Mascarenhas, A. F. S; Weirich, J.; Câmara, V. M.; Cleary, D. Mercury exposures in riverside Amazon communities in Pará, Brazil. Environmental Research., Section A 84, p-100-107, 2000.

Santos, E. C. O; Câmara, V.M.; Jesus, I. M.; Brabo, E. S.; Loureiro, E. C. B.; Mascarenhas, Fayal, K.F.; Sá Filho, G. C.; Sagica, F.E.S.; Lima, M.O.; Higuchi, H.; Silveira, I.M. A contribution to the establishment of reference values for total mercury levels in hair and fish in Amazônia.. Environmental Research., Section A 90, p-6-11, 2002.

Santos, L. S. N.; Muller, R.; Sarkis, J. E. S.; Alves, C. N.; Brabo, E. S.; Santos, E. O; Bentes, M. H.. Evaluation of total mercury concentrations in fish consumed in the municipality of Itaiba, Tapajós's River Basin, Pará, Brazil. The Science of the Total Environment, 261, p. 1-8, 2000 .

Scagliusi, F. B.; Lancha Júnior, A. H. Subnotificação da ingestão energética na avaliação do consumo alimentar. Revista de Nutrição, v. 16, n. 4, Campinas, 2003. 
Sichieri, R., Szarfac, S.C., Monteiro, C.A. Relação entre dieta e ocorrência de anemia ferropriva em crianças. Jornal de Pediatria, v.64, n.5, p.169-174, 1988.

Skoog, D.A.; Holler, F.J.; Nieman, Princípios de Análise Instrumental. São Paulo, Bookman, $5^{\text {a }}$ ed., 2002.

Silva, J.J.R.F.; Williams, R.J.P. The biological chemistry of the elements: the inorganic chemistry of life. New York: Oxford University Press; 1993.

Silva, D.G.; Franceschini, S.C.C.; Priore, S.E., Ribeiro, S.M.R.; Szarfarc, S.C.; Souza, S.B.; Almeida, L.P.; Lima, N.M.M.; Maffia, UC.C. Anemia ferropriva em crianças de 6 a 12 meses atendidas na rede pública de saúde do município de Viçosa, Minas Gerais. Revista de Nutrição, vol.15, no.3, Campinas, 2002.

Silva-Forsberg, M.C.; Forsberg, B.R., Zeidemann, V. Mercury Contamination in Humans linked to river. AMBIO, Stockholm, v. 28, p. 519-520, 1999.

Soares, E.; Saiki, M.; Nunes, E.; Wiebeck, H. Caracterização de polímeros e determinação de constituintes inorgânicos em embalagens plásticas metalizadas. Polímeros, vol.12, no.3, p. 206-212. São Carlos, 2002.

Souza, J.R.; Barbosa, A. C. Contaminação por Hg e o caso da Amazônia. Química Nova na Escola, n. 12, p.23-25, 2000.

SUFRAMA - Relatório elaborado pela Câmara Setorial da Agroindústria da zona Franca de Manaus. Superintendência da Zona Franca de Manaus, 2000.

Strand T.A.; Chandryo, R.K.; Bahl, R.; Sharma, P.R.; Adhikari, R.K.; Bhandari, N. et al. Effectiveness and efficacy of zinc for the treatment of acute diarrhea in young children. Pediatrics; 109(5), p. 898-903, 2002.

Suzuki, T.; Imura, N.; Clarkson, T. W. Advances in Mercury Toxicology. Proceedings of a Rochester International Conference in Environmental Toxicity, Tokio, Japan, 1-3, 1991.

Szckurek E.I.; Bjornsson, C.S.; Taylor, C.G. Dietary zinc defficiency and repletion modulate metallothionein immunolocalization and concentration in small intestine and liver of rats. Journal of Nutrition; 131, p. 2132- 2138, 2001.

Takeucki, T.; Eto, K. The Pathology of Minamata Disease: A Tragic Story of Water Pollution (1999). Publisher: Kyushu University Press Kyushu, Japan, 1999. 
Tanguy, S.; Besse, S.; Ducros, V.; Leiris, J.; Boucher, F. Effect of increased dietary selenium intake on blood and cardiac selenium status duang aging in rats. Nutrition Research 23, p.239-243, 2003.

Tucker, K. L.; Hannan, T.M.; Chen, H.; Cupples, L.A.; Peter, W. F.; Wilson, P. W. F.; Kiel, D. P. Potassium, magnesium and fruit and vegetable intakes are associated with greater bone mineral density in elderly men and women. American Journal of Clinical Nutrition, v 69, p. 727-736, 1999.

UNEP CHEMICALS. Impacts of mercury on the environment. In:__.Global mercury assessment. Swtzerland: $2002 . \quad$ INEP, chap. 5. Disponível em: http://www.chem.unep.ch/mercury/WGmeeting/revreport-Ch5.pdf.

Vannucchi H, Freitas LS, Szarfarc SC. Prevalência de anemias nutricionais no Brasil. Cadernos de Nutrição, 4, p.7-26, 1992.

Vasconcellos, M.B.A. ; Bode, P. ; Paletti, G. ; Catharino, M.G.M. ; Ammerlaan, A.K ; Saiki, M. ; Favaro, D.I.T. ; Byrne, A.R. ; Baruzzi, R. ; Rodrigues, D.A. Determination of mercury and selenium in hair samples of Brazilian Indian populations living in the amazonic region by NAA. Journal of Radioanalytical and Nuclear Chemistry. 244 (1), p.81-85, 2000.

Villar, B.S. Desenvolvimento e validação de um questionário semi-quantitativo de frequiência alimentar para adolescentes. 2001, Tese (Doutorado). São Paulo: Faculdade de Saúde Pública da Universidade de São Paulo.

Xavier, C. Validação de métodos de ensaios químicos. Universidade Tecnológica Federal do Paraná. Apostila: Curso de especialização em química analítica ambiental, 2006.

Yuyama, L.K.O; Aguiar, J.P.L.; Macedo, S.H.M.; Gioia, T.; Yuyama, K.; Fávaro, D.I.T.; Afonso, C.; Vasconcelos, M.B.A; Cozzolino, S.M.F. Determinação dos teores de elementos minerais em alimentos convencionais e não convencionais da região amazônica pela técnica de análise por ativação com nêutrons instrumental. Acta Amazônica 27(3), p. 183-196, 1997.

Yuyama, L. K. O; Vasquez, a. L. V.; Aguiar, J. P.L.; Macedo, S. H. M.; Yonekura, L.; Nagaham, D.; Fonseca, C. W. Composição química e adequação da alimentação oferecida aos préescolares de uma instituição beneficente de Manaus, Amazonas, Brasil. Acta Amazônica, 20 (4), p. $549-554,1999$. 
Yuyama, L.K.O., Nagahama, D., Rodrigues, M.L.C.F., Alencar, F.H.I., Marques, E.O., Cordeiro, G.W.O. Estado nutricional e anemia ferropriva em pré-escolares de uma Unidade Filantrópica de Manaus AM. In: OBESIDADE E ANEMIA NA ADOLESCÊNCIA, 2000, Salvador. Anais... Salvador, p.209-210, 2000.

Waterlow, J.C. - Malnutrición Protéico-energética. Publicação Científica, n. 55, OPS, 510 p., 1996.

Watts, D.L., 2006. Written response to two flawed articles on hair analyis available. Trace Elements: Serving the healthcare profissional with quality and integrity since 1984. Disponível em URL: http://www.traceelements.com/writtenresponse.html\#HairMercury. Acesso 12/j/2006.

Weihe, P.; Grandjean, P.; Jorgensen, P.J. Aplication of hair-mercury analysis to determine the impact of a seafood advisory. Environmental Research 97, p. 201-208, 2005.

Weldy, N. Liquidos y electrólitos del organismo: texto programado. Bueno Aires: Editoral Médica Panamericana, 1973.

Whitmire, S.J. Água, eletrólitos e equilíbrio ácido-base. In: Mahan, L. K., Scott-Stump, S. Krause: alimentos, nutrição e dietoterapia. 10. ed. São Paulo: Editora Roca, 2002.

WHO, World Health Organization, Pesticide residues in food. Techn. Rep. Serv., n. 502, Geneva, 1972.

WHO, World Health Organization,1985. Requerimentos de energia e proteína. Genebra, 1985. $206 \mathrm{p}$.

WHO/IPCS, 1990. Envirnomental Health Criteria 101: Methylmercury, WHO, Geneva.

WHO, World Health Organization, 1994. General standard for contaminants and toxins in foods. The Netherlands: Codex Alimentarius Commission, Dec. (CX/FAC 95/12).

WHO, World Health Organization, 1996. Trace Elements in Human Nutrition and health. Library Cataloguing: Geneva.

WHO, World Health Organizatio, 1999. Progress towards the elimination of Iodine Deficiency Disorders. Geneva, World Health Organization, 1999 (Document WHO/NHD/99.4).

WHO, World Health Organizatio, 2001. Iron deficiency anaemia: assessment, prevention and control. A guide for programme managers. Geneva, World Health Organization, (Document WHO/NHD/01.3). 
WHO, World Health Organizatio, 2003. Diet, food supply and obesity in the Pacific. Manila, World Health Organization, Regional Office for the Western Pacific, 2003.

Willet, W.C. Nutritional Epidemiology. New York: Oxford University Press, 1998. 